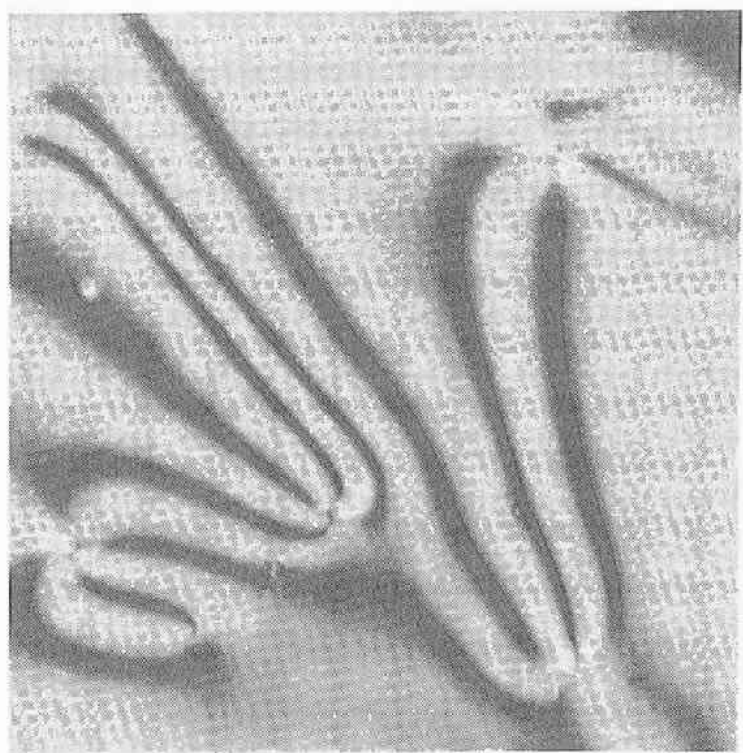

$4,4^{\prime}$-ジとドロキシアソソヘンゼンと $\alpha, \omega$-脂肪族ジカ ルボン酸塩化物との界面重縮合により得られたポりエ ステルの光学組織。ネマチック液晶特有のシニリーレ ン組織。降温過程, $236.8^{\circ} \mathrm{C}$ (提供: 東理大 小出直之)

\title{
TECHNICAL REPORTS
}

\section{高分子工業の技術および市場開発動向}

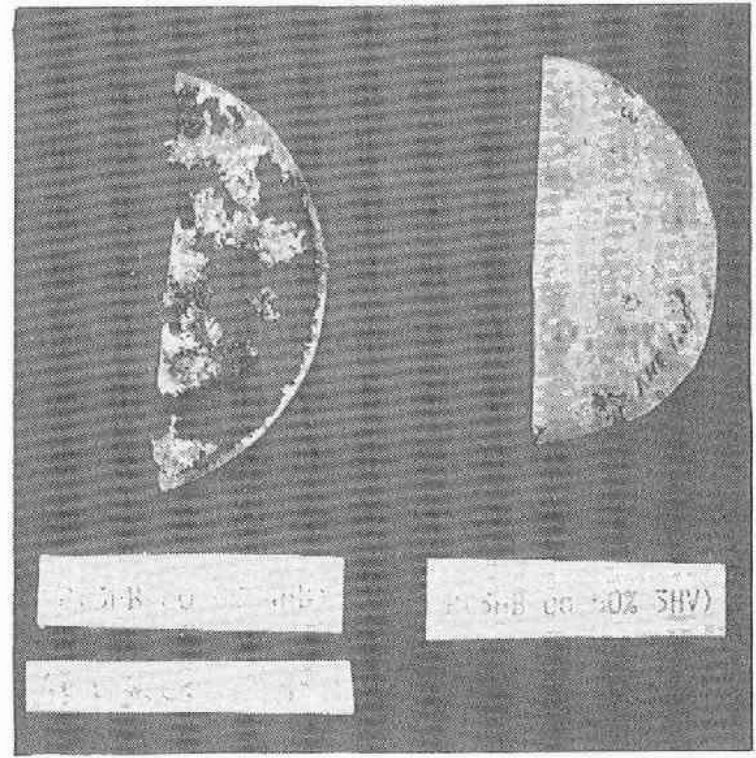

土中に 6 週間埋めて微生物によって分解されたパイオポ リエステルフィルム（提供：東工大資源研 土肥義治） 


\section{サイトップ}

\section{透明フッ素樹脂}

\section{1. 技術の背暴}

サイトップ (CYTOP) は，旭硝子が長年にわたつ て蓄積したフッ素化学のポテンシャルを駆使して開発 した新しいフッ素樹脂で, 従来知られているフッ素樹 脂とは重合反応，ポリマー構造，物性などまったく異 なる画期的菜材である。サイトップはフッ素樹脂本来 の優れた化学的, 電気的, 熱的特性を有しながら透明 度が極めて高いのが特徵であり，また特殊な溶媒に溶 解させることができる。

2. 特長

1) 光学的特性

可視光に対し PMMA (ポリメチルメタクリレート) と同等の透過率 $(95 \%)$ を示す.さらに CYTOP は 紫外光に対しても高い透過率を示す（図 1). 可視 および近紫外光の吸取がなく劣化を受けることがな い. 属折率は既存のパーフルオロポリマー（FEP など）と同じく低い (1.34).またアッべ数が極め て高く (90 以上), 色取差を生じ難い．

2) 電気的特性

PTFE などと同様, 電気絶縁性が高く(>10 $17 \Omega$ ・ $\mathrm{cm})$, 誘電率が低い $(2.1 \sim 2.2)$.

3) 化学的特性

PTFE などの既存のフッ素樹脂と同様に強酸, 強アルカリ, 油, 溶剤などほとんどの化学薬品によ って分解，溶解，膨潤を受けない。

4) 熱的特性

熱分解温度は PTFE などと同様高い $\left(400^{\circ} \mathrm{C}\right.$ 以 上).

5）機械的特性

既存のフッ索樹脂と同等の強度を示し，また弾性 率は PTFE の 2 倍以上高い $\left(12,000 \mathrm{kgf} / \mathrm{cm}^{2}\right)$.

6) 成形加工性

融溶成形により容易に加工できる．また特殊なフ ッ素系溶剂に溶解するのでキャスト法による薄膜形 成（数百 $\AA$ ), コーティングなども可能である.

3. 用途

・オプトエレクトロニクスデバイス部材（光ファイバ クラッド, レンズ系, 素子接着戍など)

・䉓気，電子部材（絶縁コートなど）

・石英代替品 (分光セル, VV 透過空など)

・保護コート（耐薬品コート，防湿コートなど）

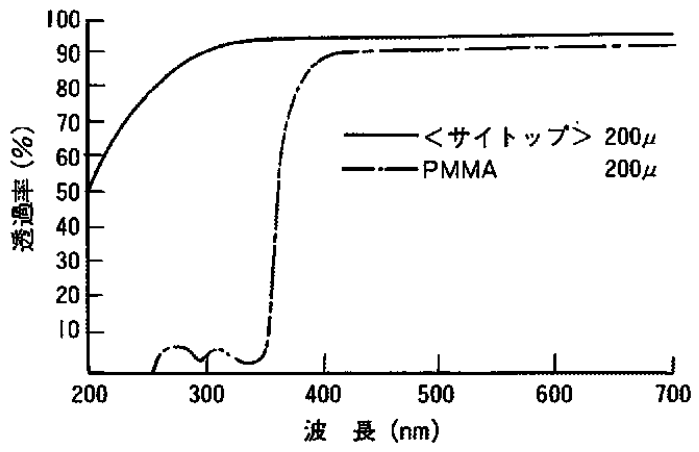

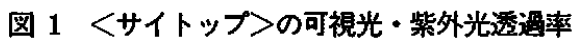

表 1 〈サイトップ〉の特性

\begin{tabular}{|c|c|c|c|}
\hline 項 & 〈サイトップ & PTFE & PMMA \\
\hline 届 折 率 & 1.34 & 1.35 & 1.49 \\
\hline 光線 透過率 & 95 & 不透明 & 93 \\
\hline$\vec{P} ッ へ$ 数 & & - & 55 \\
\hline 誘 電 率 & $2.1 \sim 2.2$ & $<2.1$ & 4 \\
\hline 誘電 正接 & 0.0007 & $<0.0002$ & 0.04 \\
\hline $\begin{array}{l}\text { 体䆏抵㧲率 } \\
\left(\Omega \cdot \mathrm{cm}^{-1}\right)\end{array}$ & $>10^{17}$ & $>10^{18}$ & $<10^{16}$ \\
\hline $\begin{array}{c}\text { 緦縁破壊電压 } \\
(\mathrm{kV} / 0.1 \mathrm{~mm})\end{array}$ & 11 & 13 & 2 \\
\hline$T_{\mathrm{g}}\left({ }^{\circ} \mathrm{C}\right)$ & 108 & $(130)$ & $105 \sim 120$ \\
\hline 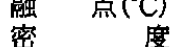 & なし & 327 & $160 \sim 200$ \\
\hline$\left(\mathrm{g} \cdot \mathrm{cm}^{-3}\right)$ & 1.84 & $2.14 \sim 2.20$ & $1.19 \sim 1.20$ \\
\hline 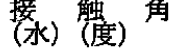 & 110 & 114 & 80 \\
\hline 吸留) $\left(60^{\circ} \mathrm{C}, 7\right.$ 率 $)$ & $<0.01$ & $<0.01$ & 0.3 \\
\hline $\begin{array}{l}12 N \mathrm{HCl} \\
\left(60^{\circ} \mathrm{C}, 7 \mathrm{G}\right)\end{array}$ & (9) & () & $\Delta$ \\
\hline $\begin{array}{l}10 \% \mathrm{NaOH} \\
\left(60^{\circ} \mathrm{C}, 7 \mathrm{G}\right)\end{array}$ & () & (0) & 0 \\
\hline 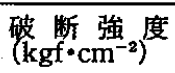 & 330 & $140 \sim 350$ & $650 \sim 730$ \\
\hline 破 & 50 & $200 \sim 400$ & $3 \sim 5$ \\
\hline $\begin{array}{l}\text { 隆 伏 応力 } \\
\left(\mathrm{kgf} \cdot \mathrm{cm}^{-2}\right)^{-1}\end{array}$ & 400 & $110 \sim 160$ & (650) \\
\hline 弾 $($ 性 & 12,000 & 4,000 & 30,000 \\
\hline
\end{tabular}

\section{旭硝子(株)}

中央研究所

(321 横浜市神奈川区羽沢町 1150

80 045-381-1441(代表) フッ素化学グループ 


\section{スペイシー F（PTFE 焼結多孔体）}

\section{PTFE（ポリテトラフルオロエチレン）}

\section{1. 技術の背景}

スペイシーFはスペイシーケミカル(株)が PTFE を素材として永年にわたって培われた焼結技術を駆使 して作り上げた気孔径 $20 \mu \mathrm{m} \sim 80 \mu \mathrm{m}$ の高分子焼結 多孔質体であります. 従来の一般的な熱可塑性樹脂を ベースとした多孔体に比較して, 而熱性, 耐薬品性に 卓越した性能を発揮し, 最近では各種の分野でその有 効性が注目されている「オゾン」に対し優れた耐性を 示します.

最近当社にて PTFE 多孔体の表層のみを親水化す ることにより均一な微細気泡を発生させることに成功 しました. (スペイシー FX) 写真-(I)

\section{2. 成形可能な形状}

肉厚 $2 \mathrm{~mm} \sim 15 \mathrm{~mm}$, 筒（長さ $500 \mathrm{~mm}$ まで），板 (350 mm 角以内), 異形品もできます.

\section{3. 製品規格および圧力損失}

〈製品規格〉

\begin{tabular}{|c|c|c|c|}
\hline 項 目 & $\mathrm{F}-30$ & $\mathrm{~F}-60$ & $\mathrm{FX}-30, \mathrm{FX}-60$ \\
\hline 気孔径 $(\mu \mathrm{m})$ & $20 \sim 40$ & $40 \sim 80$ & \multirow{3}{*}{$\begin{array}{l}\text { 物性的にはF-30, } \\
\text { F-60と同じ.たた } \\
\text { し表尿は親水性 }\end{array}$} \\
\hline 気孔率 (\%) & $40 \sim 50$ & $40 \sim 50$ & \\
\hline $\begin{array}{l}\text { 曲げ強度 } \\
(\mathrm{kg} / \mathrm{mm})\end{array}$ & 1.02 & 1.02 & \\
\hline
\end{tabular}

\section{〈圧力損失〉}

○外径 $70 \phi$ 内径 $50 \phi$ 長さ $500 \mathrm{~L}$ (湿式：水中 $200 \mathrm{~mm}$ にて)
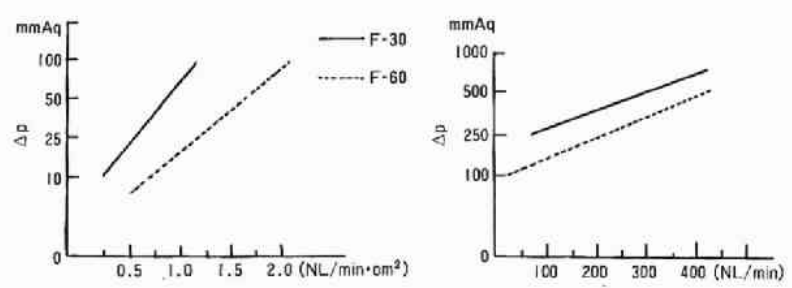

\section{4. 特徵および用途}

〈特徴〉

○耐熱性に優れている

\begin{tabular}{l|r|r|r|r|r}
\hline 項 目 樹 脂 & PTFE & LDPE & HDPE & PP \\
\hline 融 点 $\left({ }^{\circ} \mathrm{C}\right)$ & 330 & 115 & 130 & 160 \\
\hline 連続使用可能温度 $\left({ }^{\circ} \mathrm{C}\right)$ & 260 & 70 & 110 & 110 \\
\hline
\end{tabular}

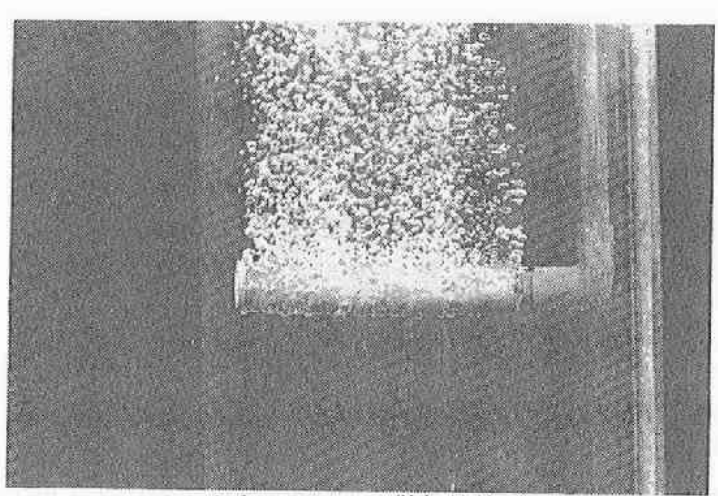

〈スペイシー FX の散気状態〉

外径 $30 \phi$, 内径 $18 \phi$, 長さ $150 \mathrm{~L}$

○耐薬品性に優れている

\begin{tabular}{|c|c|c|c|}
\hline オソンン & (a) & キ シ $レ ン$ & (2) \\
\hline フレオン & () & ナフタリン & (a) \\
\hline クロロホルム & $\mathrm{O}$ & ガ ソ リ ン & (C) \\
\hline クレソール & (a) & 塩 酸 $\left(25 \% 70^{\circ} \mathrm{C}\right)$ & (a) \\
\hline ジクロルベンゼン & (C) & 蟻 酸（90\%） & (a) \\
\hline アルデヒド類 & (a) & 発 煙 硝 酸 & (a) \\
\hline ヶトン 類 & (a) & 発 煙 硫 酸 & (C) \\
\hline へキサン & (a) & 塩素 ガ ス & (a) \\
\hline ベンゼン & (9) & 水酸化カルシウム & 0 \\
\hline $7 \pm, ー ル$ & (a) & 水酸化ナトリウム & $\mathrm{O}$ \\
\hline トルエン & $\mathrm{O}$ & & \\
\hline
\end{tabular}

〈用途〉

・オゾン，塩素ガスなどの散気板（管）

・酸化性液の沪過材

・医療用部品

5. その他主な新製品

・活性炭瀻維成形多孔体 (FAC)

・多孔性熱水成形材 (ポロソフト)

$70^{\circ} \mathrm{C}$ (水分を含んた゚状態) で軟化し冷却すると 元の多孔質体と同じ硬さになる特徴を有している PAN 系多孔質体

$$
\text { スペイシーケミカル }
$$

東京営業所 101 東京都千代田区内神田 3-8 5 ธా 03-256-8041 FAX 03-256-8043 本社開発部 $\mathbf{\Xi} 192$ 東京都八王子市元横山町 1-24-4 20 0426-46-1424 FAX 0426-46-3430 


\section{セフラルソフト}

\section{軟質系フッ素樹脂}

\section{1. 技術の背景}

一般にフッ素樹脂は四フッ化エチレン樹脂をはじめ として, 耐熱性, 耐薬品性, 耐候性などに優れ, その 用途を拡大しつつあるが，主にチューブ；シール材フ イルム分野やそれらの複合部材分野などで，より柔軟 性のあるフッ素樹脂を望む声が高くなっている. 特に これらの分野で要望されているものは成形加工性に優 れた柔軟性樹脂であり, フッ素樹脂メーカー各社の開 発目標の一つになってきている. セントラル硝子は, フッ素系のファインおよびスペシャリティークミカル ズの開発の一環として新しい軟質系フッ素樹脂を開発 した.これは特殊なグラフト重合法を利用し，フッ索 コムに結晶性のフッ索系樹脂をグラフトさせたもの で，通常のフッ素樹脂に比べて柔らかく，フッ素ゴム に比べて耐薬品性などに優れている.また押出成形, 射出成形などの一般的な成形が容易にできるため, 広 い応用分野が期待できる。

\section{2. 特長}

（1）従来のフッ素樹脂より柔軟性に富む。

（2）耐藥品性, 而候性汇優れる.

（3）気体透過性が低く，難燃性である.

（4）耐熱老化性，耐放射線性が良好.

(5) 無加硫でゴム弾性を示す.

（6）可塑剂などの充填剤が添加されていない.

（7）押出成形，射出成形などの溶融成形が容易 (成形温度 $180 \sim 200^{\circ} \mathrm{C}$ ).

（8）溶接性，ヒートシール性が良好. 高周波溶接可.

（9）着色が自由で，無処理で接着および塗装が可能.

\section{3. 「セフラルソフト」の一般的性質}

比重 : 1.78

引張強さ : $230 \sim 315 \mathrm{kgf} / \mathrm{cm}^{2}$

伸び : 460 〜00\%

引張弾性率 : $800 \sim 1,000 \mathrm{kgf} / \mathrm{cm}^{2}$

引裂き強さ : $110 \sim 120 \mathrm{kgf} / \mathrm{cm}$

アイゾット衝撃強さ：>60 kgf $\cdot \mathrm{cm} / \mathrm{cm}$

硬さ (ショアーD) : 45〜 50

反発弾性：35\%

圧縮永久歪み $:$ 中

酸素透過係数 : $27 \mathrm{cc} \cdot \mathrm{mm} / \mathrm{m}^{2} \cdot 24 \mathrm{hr}$, atm 窒素透過係数： $9 \mathrm{cc} \cdot \mathrm{mm} / \mathrm{m}^{2} \cdot 24 \mathrm{hr}$, atm 酸素指数: 54

融点 : $165^{\circ} \mathrm{C}$

ガラス転移温度 : $-25^{\circ} \mathrm{C}$

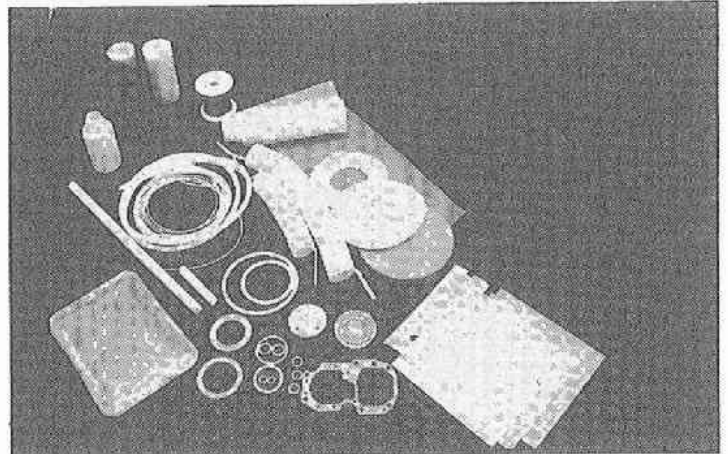

セフラルソフトの各種成形品

熱分解温度： $380^{\circ} \mathrm{C}$

高温使用限界：120 $150^{\circ} \mathrm{C}$

低温使用限界 (ゲーマン $\mathrm{T}_{2} \sim \mathrm{T}_{10}$ ) : $-7 \sim-29^{\circ} \mathrm{C}$

低温使用限界 (脆化温度) : $-55^{\circ} \mathrm{C}$

吸水率: $0.04 \%$

耐酸性：優

耐アルカリ性：優

耐油・耐溶剂性：優

(ただし，ケトン・エステルなどは不可)

耐污染性：良好

成形法：押出，射出，压縮. 後架橋可能.

\section{4. 用途}

（1）圧縮成形品/Oリング, ダイヤフラム, 各種シー ル材 (半導体工業, 食品工業向けなど)

（2）押出成形品／チューブ (医療用, 㦃業用), ホー ス,フィルム, シート (耐食ライニング他), 電 線被覆

（3）射出成形品/各種シール材，摺動部材

（4）複合材/フッ化ビニリデン樹脂へのブレンドによ る耐衝撃性, ストレスクラックの改良. ゴム (NBR，EPDM など) とのラミネート

\section{セントラル硝子 (株)}

本社 化成品研究開発部弗素樹脂開発室

(101 東京都千代田区神田錦町3-7-1 (興和一橋ビル)

zౌ 03-259-7375 FAX 03-293-2145

大阪支店 弗素樹脂課

(530 大阪市北区曾根崎 2-5-10 (梅田三井ビル)

2 06-315-1541 


アクリル超微粉体 MP シリーズ

ポリメチルメタクリレート

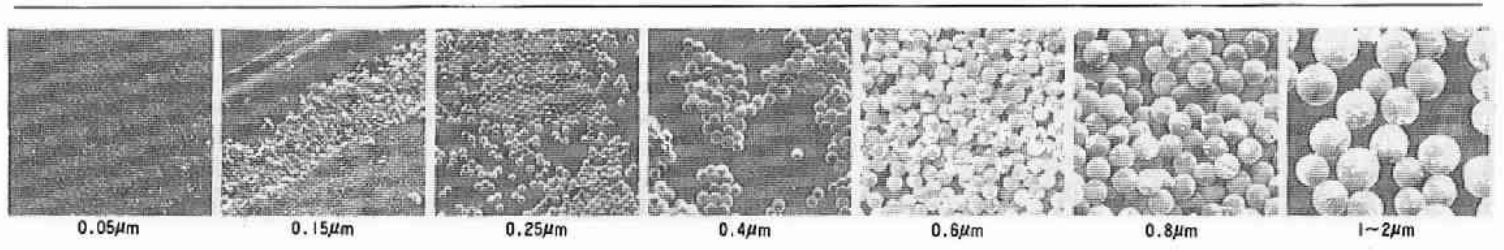

\section{1. 技術の背景}

当社が世界に先駆けて, 独自の技術で開発したアク リル超微粉体 MP シリーズは, サブミクロン粒子の 機能を積極的に利用することを目的とした製品であ り，当社が長年培ってきたアクリル重合技術と新たに 開発した微粉体製造技術とから生まれたユニークな製 品です

\section{b. 特徵および用途}

（1）完全球状で粒子の大きさが均一です.

（2）界面活性剽を含んでいません.

（3） 1 個 1 個の粒子に解砕されています.

(4) 吸湿性が少なく, 摩擦带電性が強い性質がありま す

（5）分散性に優れ，粒体への少量添加で流動性や表面 改質に大きな効果を発揮します.

（6）熱, 機械的応力, 有機溶媒により造膜します.

代表的な製品 MP-1000の性状を表に示します. MP シリーズは, 超微粉体を構成する 1 個 1 個の粒子 がよくほぐれており, プラスチックをはじめとする有 機粉体, 顔料, セラミックス, 金属粉末など各種粉体 に対し，簡単な混合操作で速やかに分散する特性をも っています.この優れた分散性は, アクリル超微粉体 の特異な帯電現象によるものですが，当社はこの特異 な帯電現象を利用して, 粉体表面に均一に付着させた のちにカプセル膜とする画期的なマイクロカプセル化 技術を生み出しました，MPシリーズでは，このよう な特性を引き出すためさまざまな工夫を施し, 多様化 する用途への対応を図っております。

\section{3. 用途}

トナー用添加剂, 顔料分散剤, 金属精密鋳造用バイ ンダー添加剤, 粉末成形用バインダー, 凹凸付与剤 (スペーサ), 紙処理剤, 流動性改良剤, ブロッキング 防止剤, 帯電制御剤, 表面保護剤, 充填剤, 化粧品 ᄀ アンデーション素材, ろ過助剤, 検定用 (物差し), ケ゚ル化肪, 凝集剤, 保留剤(医薬・農薬・香料)その他

\section{4. その他}

当社では, ユーザーの皆様からのご要望に応じて試 作を承っておりますので, お気軽に御相談下さい.

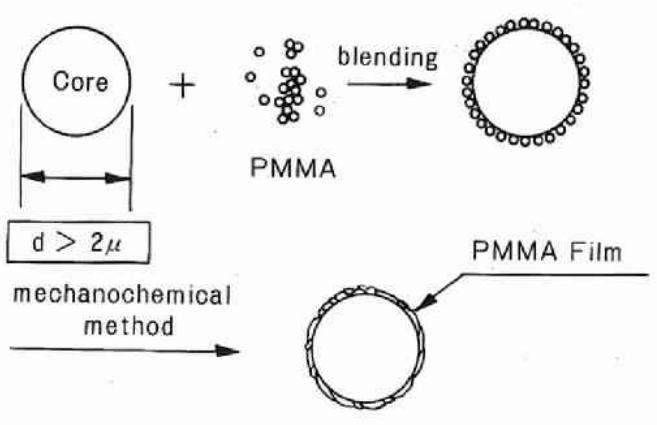

図 1 乾式混合マイクロカプセルの製造モデル図

表 MP-1000 の性状

\begin{tabular}{lc}
\hline 外 観 & 白色微粉末状 \\
単位粒径 & $0.35 \sim 0.45 \mu \mathrm{m}$ \\
分子量 $\left(M_{\mathrm{w}}\right)$ & 25 万〜 50 万 \\
組 成 & ポリメチルメタクリレート \\
ガラス転移点 & $120 \sim 130^{\circ} \mathrm{C}$ \\
熱分解温度 $(50 \% \mathrm{wt} \mathrm{loss)}$ & $330 \sim 350^{\circ} \mathrm{C}$ \\
含有水分量 & $2 \%$ 以下 \\
カ サ* $(\mathrm{m} l / \mathrm{g})$ & $9 \sim 11$ \\
比表面積** $\left(\mathrm{m}^{2} / \mathrm{g}\right)$ & 13 \\
吸油量 $(\mathrm{ml} l / 100 \mathrm{~g})$ & $68 \pm 2$ \\
$\mathrm{pH}(5 \%)$ 分散媒水 & 6.8 \\
\hline
\end{tabular}

* JISK 5101 による. ** BET 法による.

\section{綜研化学（株）}

新事業開発部

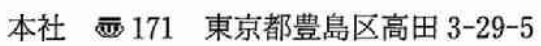

జ 03-983-3179

大阪党業所 $\mathbf{W} 530$ 大阪市北区西天満 5-1-19

8ౌ 06-362-6951

研究所 严 350-13 埼玉県狭山市上広瀬 130

: 0429-54-1113 


\section{ルブロン ${ }^{\circledR}$}

\section{フッ素樹脂固体潤滑剤}

ルブロン®は，低分子四フッ化エチレン樹脂 (PTFE) であり，プラスチックやゴム材料，塗料や オイルなどに添加することによって潤滑性や耐摩耗 性, さらに非粘着性など優れた特性を付与します。

1. 特徵

ルプロン®は，グラファイトや二酸化モリブデンな ど他の固体潤滑剤が黒色系であるのに対して白色であ り，しかも優れた潤滑性・非粘着性を持っています. そのためさまざな色調の潤滑材が得られます．また ポリフロン® TFE (弊社成形用四フッ化エチレン樹 脂）と同様, 耐熱性, 耐薬品性, 優れた電気特性, 耐 候性，非粘着性などの特性も兼ね備えています.

表 1 に潤滑性の目安になる静摩擦係数を他の固体潤 滑剤と比較して示します.

2. 用途

1）樹脂・コムへの添加

ルプロン®を, ポリアセタール，ポリアミド（ナイ ロン), ポリカーボネート,フェノール樹脂などのプ ラスチックや各種エラストマーに添加することにより 摩擦係数を下げ，摩耗を減少するとともに，表面の非 粘着性を高めることができます，特にスティック・ス リップの防止に有効です.これらの効果によって各種 軸受, 歯車, キーポードのキーなどに使っています

2）塗料への添加

ルプロン® を各種塗料へ添加することによって, 塗 膜の摩擦, 摩耗特性の改善と同時に非粘着効果が高め られ，カメラの摺動部品や自動車のウインドガラスー スライド (グラスラン) に使っています.

3）オイルおよびグリースへの添加

潤滑油やグリースの極圧添加㓲として使用すること により極圧性が向上し, 潤滑油の寿命も長くすること ができます。

4）金属の塑性加工助剤

ステンレスの伸線加工や缶のしは包加工における加 工助剤として使用しています。

5）その他の応用

カーワックス，スキーワックスなどにも使用してい ます。

\section{3. 将来の動向}

最近, $\mathrm{OA}$ 機器や自動車においては, 新機種の開発 がめざましく, 軽量化, 小型化と同時に性能の改善も 求められるようになってきた.

これらのニーズに応えるために，エンジニアリング

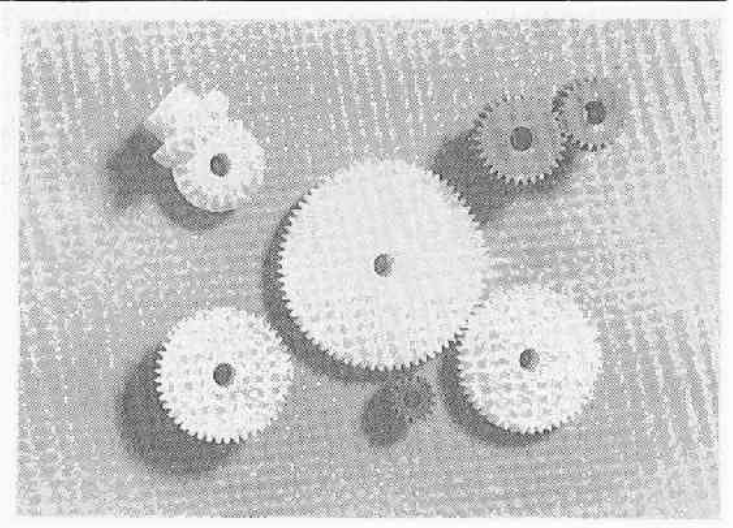

表 1 固体潤滑剤の静摩擦係数

\begin{tabular}{l|c}
\hline \multicolumn{1}{c|}{ 固体 潤 滑剂 } & 静 摩 擦 係 数 \\
\hline ルブロン® & $0.05 \sim 0.07$ \\
カーポン & $0.2 \sim 0.3$ \\
グラファイト & $0.15 \sim 0.16$ \\
二硫化モリブデン & 0.15 \\
\hline
\end{tabular}

プラスチックスやゴムなどのルブロン®による改質を 行うケースが増加してきている。

今後これらの用途の他，インク．塗料などへの応用 も期待できる.

\section{ダイキン工業（株）}

化学事業部営業企画部 本社

⑤30 大阪市北区中崎西 2-4-12 (梅田センタービル) 8ా 06-373-1201（代表） 


\section{ニポリット}

\section{塩化ビニル樹脂}

\section{1.はじめに}

チッソ（株）は昭和 12 年, 試験的に塩化ビニル樹 脂の少量生産を行い, 昭和 16 年, 日本で最初に塩化 ビニル樹脂の生産，販売を開始しました。“ニポリッ ト”の名はこのときにつけられたもので,以来, 硬 質・軟質・電線被覆などに広く使用されています“ニ ポリット”には多くの品種が用意されており，高度の 加工技術に応じて最適の樹脂をご利用いただけます。 いずれも樹脂に要求される性翼に優れ，需要家の皆様 の御指導を考魔して改良に改良を重ねてきたもので す.

\section{2. 品種と特徵}

(1) S系ポリマー（ストレート樹脂）

\begin{tabular}{l|c|c|c|c|c}
\hline グレード & SH & SM & SL & SR & SE \\
\hline 平均重合度 & 1450 & 1300 & 1030 & 800 & 700 \\
\hline
\end{tabular}

特 徵

○軟質用途……熱安定性, 加工性, 透明性, 耐候性, 電気的性筫が優れている，粒子は多孔性で可塑剂の吸 収性がよく，ドライブレンド押出などに適する。 ○硬質用途……熱安定性, 加工性, 透明性が優れてい る. 安定剤の吸取およびゲル化性が優れているので粉 末押出に適する。

（2） S系ポリマー特殊品

\begin{tabular}{c|c|c|c|c|c}
\hline グレード & SZ-7 & SV-13 & SQ-9 & SG & S-450 \\
\hline 平均重合度 & 700 & 1300 & 900 & 600 & 450 \\
\hline
\end{tabular}

特 徵

SZ, SV は従来のストレート塩化ビ二ル樹脂に比 し，可塑㶡の吸収性が抜群に優れ，ゲル化性を向上さ せたグレードである.SQは硬質押出用で加工性を改 良したグレードで，SG，S-450は特に流れ特性を向 上させ射出成形用に適したグレードである。

（3） M系ポリマー（酶酸ビニル共重合樹脂）

\begin{tabular}{c|c|c|c}
\hline グレード & $\mathrm{MH}$ & $\mathrm{MR}$ & $\mathrm{MQ}$ \\
\hline 平均重合度 & 1500 & 800 & 750 \\
\hline
\end{tabular}

特 徵

䣫酸ビニルとの共重合により加工性，透明性を向上 させたグレードて，特に床材用途に適する。 また，二 次加工性が優れているので真空成形用透明板などに適 する.

(4) C系ポリマー（高重合度樹脂）

\begin{tabular}{l|c|c|c|c|c|c}
\hline グレード & $\mathrm{CM}$ & $\mathrm{CL}$ & $\mathrm{CR}$ & $\mathrm{CK}$ & $\mathrm{CH}-36$ & $\mathrm{CH}-45$ \\
\hline 平均重合度 & 2900 & 2500 & 2100 & 1800 & 3600 & 4500 \\
\hline
\end{tabular}

特 徵

塩化ビニル樹脂の重合度を高くすることによって， 従来の組成物では得られなかった特徵を出すことが可 能となり，新しい用途が開かれている．また医療用用 途に適するグレードもあります。

(1) 耐熱性の良い組成物が得られる.

(2) 腰の強い高弾性体が得られる。

(3) ベトッキの少ないしなやかな性質の組成物が得ら れる.

（5） CQ ポリマー（易加工性高重合度樹脂）

\begin{tabular}{l|c|c|c}
\hline グレード & $\mathrm{CQ}-25$ & $\mathrm{CQ}-21$ & $\mathrm{CQ}-18$ \\
\hline 平均重合度 & 2500 & 2100 & 1800 \\
\hline
\end{tabular}

特 徵

一般高重合度塩化ビニル樹脂と同様に優れた機械的 性質, 耐熱性, 而熱変形性, ゴ弾性の組成物が得ら れるが,より溶融流動性に富み, 加工性が改良された グレードで, 加工工程の省力化に寄与する.

(6) CD 系ポリマー（鄷消し高重合度樹脂）

\begin{tabular}{c|c|c|c}
\hline グレード & $\mathrm{CD}-25$ & $\mathrm{CD}-21$ & $\mathrm{CD}-18$ \\
\hline 平均重合度 & 2500 相当 & 2100 相当 & 1800 相当 \\
\hline
\end{tabular}

（7） SD 系ポリマー（艶消し樹脂）

\begin{tabular}{c|c|c|c|c}
\hline グレード & SD-7 E & SD-10 E & SD-13 E & SD-10X \\
\hline 平均重合度 & 700 相当 & 1000 相当 & 1300 相当 & 1000 相当 \\
\hline
\end{tabular}

特 徵

$\mathrm{CD}, \mathrm{SD}$ ともに特殊な手段をとらなくても従来の 塩化ビニル樹脂と同一の加工条件で, 表面外観の優れ たペタッキのない風合いと拔群の齵消し状の成形品が 得られる. CD 法可塑剤を多量に使用するゴム弾性用 途に適し, $\mathrm{SD}$ 㹥硬質, 半硬質用のフィルム, シート などに特に適している。

\section{チッソ（株）}

本社 100 東京都千代田区丸の内 2-7-3

8003-284-8552（ダイヤルイン）

大阪営業所 806-441-3252 名古屋営業所 052201-7961 福岡営業所 $\approx 092-761-7066$ (代表) 


\section{DOMINAS}

\section{ポリウレタン/塩化ビニル共重合樹脂}

ドミナスは東ソー(株) と日本ポリウレタン工業 (株) が長年にわたる塩ビおよびウレタン分野で蓄積 してきた技術に基づいて共同開発したウレタンと塩ビ の共重合樹脂である，ポリ塩化ビニル（PVC）および ポリウレタン (PU) は古くから優れた特徵をもつ樹脂 としてさまざまな用途に使用されており，それら両者 の特長をもつレジンの開発が望まれていた，従来，各 種方法によって PU と PVCのポリマーブレンドによ る複合化が検討されてきたが，両者のゲル化性，相溶 性，溶融粘度などに差があるために，ブレンドによる 複合化には限界があった。ドミナスは特殊な重合法に より複合化させており，その性能はウレタン組成，塩 ビの重合条件を変化させることによって広範囲にわた っております。特に，PU と PVC の両者の特長を優 生遗伝させた樹脂であり，種々の加工分野でさまざま な製品に使用が可能であります。

1. 特徵

（1）完全無可塑軟貿 PVC（カレンダー・・押出・射出グ レード)

（2）熱可塑性エラストマー（押出・射出グレード）

(3) 通常の PVC 用加工機で成形可能

（4） PU, PVC の特長発揮（機械強度, 非移行性, 非 污染性, 酎油性, 耐熱老化性, 耐摩耗性, 酎候性 などに優れる)

（5）広範囲なグレード立て（高硬度品〜低硬度品）

2. 用途

無可塑軟質塩ビ沉用用途および熱可塑性エラストマ 一沉用用途での使用が可能であるとともに, PU/ PVC 共整合樹脂の特徴を活汃した用途として,

(1) フィルム・シート関係

医療用フィルム, 食品包装材, 農業用フィルム, コ ンテナバック、マーキングフィルム, ターポリン, 人 エレザー，床材など

(2) 成形品関係

自動車用部品 (内・外装材), ホース・チューブ, 電 線被覆, シース材，ガスケット，靴底など

その他，ドミナスを熱可塑性ポリウレタン, PVC, NBR，ABS などとブレンドして性能改良剤としても 利用できます。

さらに，PU と PVC のブレンドには, ブレンド・ 混練工程が必要ですが，ドミナスは複合化パウダーあ るいはペレットであることより,これらの工程が省略 でき，トータルコスト面からも有利であります。
表 1 DOMINAS と他材料との特性比較

\begin{tabular}{|c|c|c|c|}
\hline 項 目 & DOMINAS & $\begin{array}{c}\text { 軟望 PVC } \\
\text { (DOP) }\end{array}$ & TPU \\
\hline 硬度ショア-A & $55 \sim 90$ & $50 \sim 100$ & $80 \sim 95$ \\
\hline 機械的強度 & $\mathrm{O}$ & $\triangle$ & (0) \\
\hline 耐 油 性 & (0) & $x$ & (C) \\
\hline 耐 寒 性 & 0 & $\triangle$ & (c) \\
\hline 耐摩耗性 & (2) & $\triangle$ & (O) \\
\hline 非移行性 & (2) & $x$ & (1) \\
\hline 耐熱老化性 & 0 & $x$ & 0 \\
\hline 透 明 性 & (O) & (c) & $\Delta$ \\
\hline 耐 候 性 & (O) & 0 & $\Delta$ \\
\hline ガスバリヤー性 & 0 & $x$ & $\Delta$ \\
\hline 難＼cjkstart燃＼cjkstart性 & 0 & 0 & $x$ \\
\hline 加 工 性 & 0 & $\mathrm{O}$ & $x$ \\
\hline
\end{tabular}

衰 2 DOMINAS の一般的性䝷

\begin{tabular}{|c|c|c|c|}
\hline & $\mathrm{K}-550 \mathrm{~F}$ & $\mathrm{~K}-700 \mathrm{~F}$ & $\mathrm{~K}-900 \mathrm{~F}$ \\
\hline 硬 度 JIS A & 55 & 70 & 90 \\
\hline 比 重 & 1.22 & 1.25 & 1.29 \\
\hline 引張強度 ${ }^{* 1}\left(\mathrm{~kg} / \mathrm{cm}^{2}\right)$ & 130 & 190 & 270 \\
\hline 伸 び*1(\%) & 640 & 540 & 380 \\
\hline 引裂強度*2 $(\mathrm{kg} / \mathrm{cm})$ & 46 & 73 & 102 \\
\hline $\begin{array}{l}\text { 而摩耗性*3 }(\mathrm{mg}) \\
\mathrm{H}-221 \mathrm{~kg} \times 1000 \text { 回 }\end{array}$ & 28 & 68 & 162 \\
\hline 脆化温度*1 $\left({ }^{\circ} \mathrm{C}\right)$ & -70 & -55 & -40 \\
\hline $\begin{array}{l}\text { 非移行性 PS,ABS } \\
80^{\circ} \mathrm{C} \times 48 \mathrm{hr}, 500 \mathrm{~g}\end{array}$ & O & 0 & $\mathrm{O}$ \\
\hline 耐油性*1残率(\%) & 102 & 98 & 99 \\
\hline 耐水性*1残率 (\%) & 96 & 103 & 93 \\
\hline 熱老化性*1残率(\%) & 101 & 98 & 96 \\
\hline
\end{tabular}

䔣油性, 酎水性, 熱老化性：引張強度残率を示す

${ }^{* 1}$ JIS K 6723, *2 JIS K 6301, ${ }^{* 3}$ JIS K 7204 


\section{エポミン ${ }^{\circledR} \mathrm{KT}$}

\section{參性ポリエチレンイミン}

\section{1. 技術の背固}

当社は国内で唯一のポリエチレンイミンおよびエチ レンイミン誘導体のメーカーで，長年培ってきたカチ オン性樹脂の合成技術を基に，新しいタイプのカチオ ン性樹脂，エポミン® $\mathrm{KT}$ を開発しました,

\section{2. 特徴および用途}

エポミン ${ }^{\circledR} \mathrm{KT}$ は分子中にポリアミノ基とポリエー テル結合を持った非常にユニークなカチオン性樹脂で す．含まれるアミノ基の量により 3 種のグレードがあ ります。製品形態は粘稠な水溶液です。

表 1 エポミンタT の性状

\begin{tabular}{|c|c|c|c|}
\hline グレード & $\begin{array}{c}\text { アミンン価 } \\
(\mathrm{mmol} / \mathrm{g} \cdot \text { solid })\end{array}$ & 分子量 & 有姿壌度 \\
\hline $\mathrm{KT}-871$ & 約 $10 \sim 11$ & 約 6 万 & $40 \%$ \\
\hline KT-872 & 約 $6 \sim 7$ & 約 6 万 & $40 \%$ \\
\hline $\mathrm{KT}-873$ & 約 $2 \sim 2.5$ & 約 6 万 & $30 \%$ \\
\hline
\end{tabular}

ポリエチレンイミンと同様に反応性の高いアミノ基 を有するため種々の変性が容易という特徵に加え，工 ポミン® $\mathrm{KT}$ は次のような特徴を持っています。

(1) 適当な架橋郕で高分子量にすることができる。

(2) 広い $\mathrm{pH}$ 領域で大きなカチオン解離度を示す.

(3) フレキシブルな構造である。

(4) 熱分解温度が高く，ポリエチレンイミンに比べ村 熱黄変性に優れている。

これらの特徴より以下の用途への展開が考えられま す.

（1）紙パルプの沪水・歩留戍

$\mathrm{KT}$ を紙パルプへ応用すると，広い $\mathrm{pH}$ 領域に扔い て良好な沪水性および墤料・サイズ威など各種添加剤 の歩留を向上することができます 特に中性抄紙条件 下で用いますと，抄紙系のクローズド化が可能となり ます。また，カチオン化ポリアクリルアミドのように

衰 2 エポミン囚 KT の沪水・歩留性

\begin{tabular}{|c|c|c|}
\hline サンプル & $\begin{array}{l}\text { 沪 水 性 } \\
(\mathrm{pH} 8)\end{array}$ & $\begin{array}{c}\text { 炭カル歩留率 } \\
(\mathrm{pH} 8)\end{array}$ \\
\hline $\mathrm{KT}-871$ & $440 \mathrm{~m} l$ & $61 \%$ \\
\hline PEI ${ }^{13}$ & 410 & 45 \\
\hline C-PAM ${ }^{2)}$ & 380 & 54 \\
\hline ブランク & 310 & 29 \\
\hline
\end{tabular}

1) ポリエチレンイミン

》カタチン化禾リアクリルアミド
大きなフロックを生成しないため，地合も容易にとる ことができます。

（2）下水，工業廃水，泥水の凝集郕

KT を活性污泥の凝集に応用しますと, フロック強 度の大きなミクロフロックを形成しますので, ベルト プレスなどにより含水率を大幅に下げることができま す。さらに脱水ケーキのハクリ性が良いという特性も 示します。

また，その反応性の高いことから，各種廃水および 丠濁液にも少量添加で大きな凝集力が得られ COD・ BOD の低隇を可能にすることができます。

（3）エポキシ樹脂硬化郕，密着・接着性付与刘

KT は低毒性の水系エポキシ樹脂硬化剂として用い ることができ，エポキシ樹脂の欠点である可掕性を改 良できます。

また，種々の基材に対し良好な密着・接着性を示し 特にポリエチレンなどの不活性表面に対しても大きな 効果が得られます。

（4）バイオ関連用途

KT をバイオリアクターから酵素を回収する際の菌 体凝集㓮として使うことができます。ささらに反応性に 富んだアミノ基を利用して，酵素を固定化する担体と して用いることもできます。

（5）セメント添加肪

耐塩性・耐熱性に優れていることから，KT をセメ ント用分散郕や保水削として用いることができます。

(6) その他

ポリエキレンイミンと同様にキレート樹脂，イオン 交換樹脂，メッキ添加剂，染料・顔料の固着剤などの 用途への応用が期待されます。

\section{日本触媒化学工業（株）}

《 541 大阪市中央区高麗橋 4-1-1（興銀ビル）

z 06-223-9188 FAX 06-201-3716 


\section{ノンハロゲン難燃性ポリエチレン樹脂}

昭和 59 年の東京都世田谷電話局とう道内で生じた ケーブル火炎は，大きな社会的影響を与えた。の 後, NTT が中心となり，ハロゲンを含まない無毒・ 無公害型のノンハロゲン難燃シース材料で被覆された ケーブルを開発した，現在，NTT では，とう道内は もちろんのこと電話局内に付設されたケーブルもすべ てこの無公害型のノンハロゲン難燃シース材料を用い たケーブルを使っている.

当社では，他社に先駆けて，このノンハロゲン難燃 シース用材料樹脂の開発にいち早く着手した。 ベース になる樹脂の選定, 難燃郕としての水酸化マグネシウ ムの選定, さらに複合樹脂として各種の特性を满足さ せるべきカップリング绪の開発などにより，優れた諸 特性をもった樹脂を開発することができた。

すなわち，当社のノンハロゲン難燃性ポリエチレン 樹脂は，ベース樹脂として当社独自の重合方法による エチレンエチルアクリレート共重合体（EEA）を使 い，難燃郕として酎水性・耐酸性に優れた水酸化マグ ネシウムを使い，さらに当社独自のカップリング剤に よって機械特性, 加工性, 長期信頼性および難燃性な どに優れた特性をもった材料となっている。

1. 代表的商品名および特徽（表）

〈特 徴〉

1）当社の高度な重合技術によってつくられた優れ た特性をもつ EEA をべース樹脂として使用し ている.

2）当社独自のカップリング剂により複合樹脂とし て優れた特性をもっている。

3）低煙性であり，ハロゲンを含まない無公害型の 難燃材料である。

4）優れた押出し加工性, 機械特性および長期信頼 性をもった材料である。

\section{2. 用途}

1）通信ケーブル用外被材料

2）電力ケーブル用外被材料

3）電線・ケーブルのジョイントカバー

4）䉓線保讙管

5) パイプ

6) シート

7) テープ

などで難燃性を要求される用途.

\begin{tabular}{|c|c|c|c|}
\hline 項 目(単位) & $\mathrm{CA} 1150 \mathrm{BM}$ & CA $1153 \mathrm{BM}$ & $\mathrm{CA} 1200 \mathrm{H}$ \\
\hline $\begin{array}{l}\text { メルトフㅁำ } \\
\text { (g/10 分) }\end{array}$ & $0 . \dot{2}$ & 0.3 & 0.2 \\
\hline${ }_{\left(\mathrm{g} / \mathrm{cm}^{3}\right)}$ 度 & 1.33 & 1.29 & 1.43 \\
\hline $\begin{array}{c}\text { 引張破罟強さ } \\
\left(\mathrm{kgff} / \mathrm{cm}^{2}\right)\end{array}$ & 135 & 140 & 115 \\
\hline $\begin{array}{c}\text { 引張破買伸び } \\
\end{array}$ & 600 & 600 & 700 \\
\hline 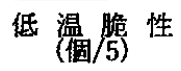 & 0 & 0 & 0 \\
\hline 酸素，指 数 & 27 & 35 & 33 \\
\hline 発 煙) 量 & 105 & 110 & 90 \\
\hline $\begin{array}{c}\text { 発生ガス } \mathrm{pH} \\
(\mathrm{pH})\end{array}$ & 4.2 & 3.8 & 4.2 \\
\hline
\end{tabular}




\section{ザイダー}

\section{液晶ポリマー}

液晶ポリマー“ザイダー”は, Amoco Performance Products 社 (当時 Dartco 社) が開発, 日本におけ る独占的販売権を当社が持っている.

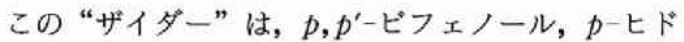
ロキシ安息香酸, テレフタル酸から成る全芳香族ポリ エステルで, ポリマーはすべて棒状の剛直な分子から 成っており, それが融点の高さ, 耐溶阂性, 強靱性, 高性能の一因となっている.

特に, “ダイザー”は熱可塑性樹脂の中で最高の耐 熱性を持ち, 優れた機械的, 電気的特性と相埃って電 気・電子産業分野で高い評価を得ておうり, 機械・自動 車, 宇宙航空産業など, あらゆる産業分野で期待を集 めている超耐熱性のスーパーエンプラである.

ザイダーの特徴を以下に列記する。

\section{（1）耐熱性}

熱変形温度は $250 \sim 350^{\circ} \mathrm{C}\left(18.6 \mathrm{kgf} / \mathrm{cm}^{2}\right)$

$\mathrm{UL}$ 認可の連続使用 (10 万時間) 温度は $220 \sim 240^{\circ} \mathrm{C}$ で, 熱劣化による減量開始温度は $560^{\circ} \mathrm{C}$, インジ ェクション成形可能な熱可塑性樹脂の中で最高の耐 熱性を持っている.

（2）難燃性

UL94 による難燃性は V-0 級. 酸素指数は $42 \sim 49$

であり，空気中では燃えない。

(3) 機械的特性

広い温度範囲で $\left(-50^{\circ} \mathrm{C} \sim 355^{\circ} \mathrm{C}\right)$ 引張り特性, 曲 げ特性, 耐衝撃性など優れた機械的強度を持つ。

（4）寸法安定性

従来の熱可塑性樹脂に比ぺて線膨張係数が非常に小 さく，金属やセラミックスに匹敵する值である.

(5) 電気特性

優れた絶縁耐力と耐アーク性を持った電気絶縁体で UL 認可の電気的連続使用温度は $240^{\circ} \mathrm{C}$, 電気用品 取締法にもとづいて登録されている.

（6）加工性

通常のエンプラ対応成形機で容易に成形可能. 非常 に良好な流動性を持っているため, 薄肉成形, 複雑 な形状の成形品でも容易に成形できる.

（7）耐薬品性

化学薬品や溶剤にさらされてもほとんど影響を受け ない.

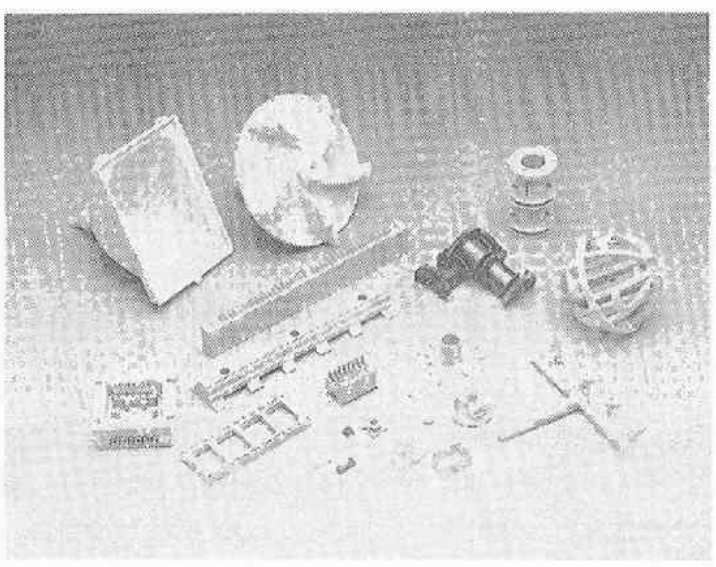

ザイダーの応用例

表 1 ザイダーの標準グレード

\begin{tabular}{|c|c|c|}
\hline & 組 & $\underset{\left({ }^{\circ} \mathrm{C}\right)}{\mathrm{HDT}}$ \\
\hline $\mathrm{RC}-210$ & ガラスファイバー & 346 \\
\hline $\mathrm{RC}-220$ & ガラスファイバー,無機フィラー & 330 \\
\hline $\mathrm{FC}-110$ & ガラスファイパー & 319 \\
\hline $\mathrm{FC}-120$ & ガラスファイパー,無機フィラー & 316 \\
\hline $\mathrm{FC}-130$ & 無機フィラー & 290 \\
\hline$G-430$ & ガラスファイバー & 313 \\
\hline $\mathrm{G}-445$ & ガラスファイバー & 307 \\
\hline $\mathrm{MG}-450$ & ガラスファイバー,無機フィラー & 293 \\
\hline$M-450$ & 無機フィラー & 285 \\
\hline $\mathrm{G}-345$ & ガラスファイパー & 268 \\
\hline MG-350 & ガラスファイバー,無機フィラー & 268 \\
\hline$G-330$ & ガラススァイバー & 266 \\
\hline $\mathrm{M}-350$ & 無機フィラー & 246 \\
\hline
\end{tabular}

\section{日本石油化学 (株)}

開発部ザイダー開発室

玉100 東京都千代田区内幸町 1-3-1

8? 03-501-7333 FAX 03-501-7636 


\section{バレックス ${ }^{\circledR}$}

\section{ポリアクリロニトリル}

バレックス®は，アクリロニトリルを主成分とする 透明で非晶質な熱可塑性樹脂です. バレックスを一次 加工したフィルム，シート，プレート形態のものをゼ クロンの商品名で提供しています。

特 徵

（1）ガス・バリヤー性（気体不透過性）

酸素，窒菜，炭酸ガスなどの不活性ガス，ガソリ ン,アルコールなどの有機溶浏ガスのほか, LPG, フロンなどの液化ガスのバリヤー性も優れる。

（2）耐薬品性（表）

多くの有機溶㨈に対して優れた耐薬品性を示す．特 に芳香族炭化水素類，アルコール類，エステル類，八 ログン化炭化水素類に対して適性を備える，耐油性， 耐ストレス・クラッキング性も有する，また，放射線 殺菌，EO 殺菌にも使用できる.

（3）保香性

香料，香辛料，精油やコーヒー，紅茶などの食品の もつ香りを保持する。

（4）薬効成分の非吸着性

医薬品や医薬部外品などに添加されている薬効成分 の吸着が少ない.

（5）深校り加工性

シート，プレートなどの熱成形では，深较り成形性 に優れる上，偏肉の少ない成形品が得られる。

（6）成形法

押出成形：フィルム, シート,プレート

ブロー成形：押出プロー，射出プロー，延伸ブロー 射出成形: 容器, 機械部品

異形押出成形：パイプ, 棒

カレンダー加エ：フィルム，シート

用 途

（1）食品包装：味㬝，菓子，鮮魚，魚卵など水産加工 品, 生肉, 八ムなど畜産加工品, 精米, 調味料など （2）薬品包装その他

溶剤・塗料：シンナー, ラッカーなど

自動車用品：ワックス，ガソリン添加剤など

文房具：修正液,インクなど

化精品：マニキュア，マスカラ、アイライナー，コロ

$$
\text { ン, 各種のエア・ゾール容器 }
$$

トイレタリー用品：芳香剤，洗净郕など

医藥品など : 風邪薬, 貼布剈, 口臭防止剤など

薬品：農藥, 殺虫剂, 忌避殽など

（3）工業用途：パイプ, 部品用コンテナーなど

\begin{tabular}{|c|c|c|}
\hline & 薬 品 名 & 温度 $\left({ }^{\circ} \mathrm{C}\right)$ 評価 \\
\hline \multirow{3}{*}{$\begin{array}{l}\text { 芳篟 } \\
\text { 稚 } \\
\text { 族䋇 }\end{array}$} & ベンゼン & 230,380 \\
\hline & トルエン & $23 \bigcirc, 38 \bigcirc$ \\
\hline & キシレン & $230,38 \bigcirc$ \\
\hline \multirow{4}{*}{$\begin{array}{l}\text { 㟶 } \\
\text { 炛 } \\
\text { 分素 } \\
\text { 化 }\end{array}$} & 四塩化炭素 & $23 \bigcirc, 38 \bigcirc$ \\
\hline & 1.1.1トリクロロエタン & $23 \bigcirc, 38 \bigcirc$ \\
\hline & トリクロロエチレン & $23 \bigcirc, 38 \bigcirc$ \\
\hline & メチレンクロライド & $23 \triangle, 38 \triangle$ \\
\hline \multirow{3}{*}{$\begin{array}{c}r \\
N \\
J \\
1 \\
N\end{array}$} & エチルアルコール & $23 \bigcirc, 38 \bigcirc$ \\
\hline & イソプロピルアルコール & $23 \bigcirc, 38 \bigcirc$ \\
\hline & グリコール & 230,380 \\
\hline \multirow{3}{*}{$\begin{array}{l}I \\
ス \\
F \\
ル\end{array}$} & ブチルアセテート & $23 \bigcirc, 38 \bigcirc$ \\
\hline & セロソルプアセテート & $230,38 \bigcirc$ \\
\hline & エチルアセテート & $23 \bigcirc, 380$ \\
\hline \multirow{3}{*}{$\stackrel{ケ}{5}$} & アセトン & $23 \triangle, 38 \triangle$ \\
\hline & メチルエチルケトン & $23 \triangle, 38 \triangle$ \\
\hline & メチルイソブチルケトン & 230,380 \\
\hline \multirow{5}{*}{ 酸 } & $10 \%$ 塩酸 & $230,38 \bigcirc$ \\
\hline & $30 \%$ 硫酸 & $23 \bigcirc, 38 \bigcirc$ \\
\hline & $100 \%$ 酶酸 & $23 \bigcirc, 38 \triangle$ \\
\hline & $30 \%$ リ酸 & $230,38 \bigcirc$ \\
\hline & $10 \%$ 硝酸 & $23 \bigcirc, 380$ \\
\hline \multirow{5}{*}{ 塩 } & $10 \%$ アンモニア水 & $23 \bigcirc, 38 \triangle$ \\
\hline & 水酸化バリウム(飽和) & $23 \bigcirc, 38 \bigcirc$ \\
\hline & 水酸化カルシウム (飽和) & $23 \bigcirc, 38 \bigcirc$ \\
\hline & 10\%水酸化カリウム & $23 \bigcirc, 38 \triangle$ \\
\hline & $10 \%$ 水酸化ナトリウム & $23 \bigcirc, 38 \Delta$ \\
\hline
\end{tabular}

試駼条件：約 $170 \mathrm{cc}$ のバレックス製ボトルに試験液を 入れ (1) $23^{\circ} \mathrm{C} 50 \% \mathrm{RH} \quad$ (2) $38^{\circ} \mathrm{C} 50 \% \mathrm{RH}$ の条件下 で,一年間保存し，外筧変化㧍よびボトルの重量変化 より耐虆品性を判定した。

評価判定： $0=1$ 年間のテストで問題なく使用できる。 $\mathrm{O}=16 \sim 20$ 週閔，問題なく使用できる。 $\Delta=16$ 週間 以内に顕著な外観・重量㚆化などを生じる。

\section{三井東圧化学 (株)}

機能性ポリマー事業部営業一部

逃 100 東京都千代田区霞が関 3-2-5

× 03-592-4729 FAX 03-592-4256 


\section{ユーピレックス}

ポリイミドフィルム

\section{1. 技術の背詈と市場勳向}

宇部興産は，長年培った有機合成技術を基に，ビフ エニルテトラカルボン酸二無水物 (BPDA) の工業的 合成技術を確立し，この BPDA の応用製品の一つと して,これまでのものと分子構造の異なる新しい夕イ プのポリイミドフィルム「ューピレックス』を開発し た.

「ユーピレックス』には, 化学構造の異なる， R夕 イプとSタイプの 2 種があり，それぞれ違った特徴を 有している. ユーピレックス-R は，主として，董電 分野における電気䋓縁材料として用いられており，一 方, ユーピレックス-S は, 䈌しい寸法安定性を要求 される高密度電子回路分野に用いられている.

特に, フレキシブルプリント回路 (FPC) や IC 赛 装用フィルムキャリア (TAB) の分野では, ラインピ ッチ $0.1 \mathrm{~mm}$ の実現が望まれて枋り，ユーピレックス -S の寸法安定性に大きな期待が寄せられている.

\section{2. 構造と物性}

ユーピレックスの構造は, 次の一般式で表わされ, $\mathrm{R}$ タイプと $\mathrm{S}$ タイプの違いは，アミン成分（郡号 $\mathrm{R}$ ) の分子構造の違いである。<smiles>[R]N1C(=O)c2ccc(-c3ccc4c(c3)C(=O)N(C(C)(C)C)C4=O)cc2C1=O</smiles>

ユーピレックスの一般物性を表 1 にまとめた。

フィルムの㯹さは, $7.5 \mu \mathrm{m}, 12.5 \mu \mathrm{m}, 20 \mu \mathrm{m}, 25$ $\mu \mathrm{m}, 50 \mu \mathrm{m}, 75 \mu \mathrm{m}, 125 \mu \mathrm{m}$ があり, 幅は $508 \mathrm{~mm}$ お よび 1,016 mm が標準となっている.

\section{3. 特徴および用途}

ユーピレックスーR の特徵は, 酎熱性をはじめ, 絶 縁欠陥が極めて少なく, 引張り伸びが非常に大きい点 である.これらの特徴を生かして, 重電分野で, 車輛 用や産業用モーターのコイル絶縁に主として用いられ ている.また，高温時の伸びが大きく，耐熱構造材の 高温真空成形用のバッグや, 絞り加工を行ったスピー カーの振動板などにも用いられている。

ユーピレックス-S は, 加熱収縮率や吸水率が小さ く,電子回路などの加工プロセスにおける熱, 水分, 薬 液による寸法変化が著しく小さいフィルムである，ま た弾性率が高く, 腰が強いことも特徴となっている。
表1 ユーピレックスの物性

\begin{tabular}{|c|c|c|c|c|}
\hline \multirow{2}{*}{ 項 } & \multirow{2}{*}{ 単 位 } & \multicolumn{2}{|c|}{ 標 準 值 } & \multirow{2}{*}{ 備考 } \\
\hline & & Sタイプ & $\mathrm{R}$ タイプ & \\
\hline 引張り強度 & $\mathrm{kg} / \mathrm{mm}^{2}$ & 40 & 25 & $* 1$ \\
\hline 引張り伸び & $\%$ & 30 & 130 & $* 1$ \\
\hline 引張り弾性率 & $\mathrm{kg} / \mathrm{mm}^{2}$ & 900 & 380 & $* 1$ \\
\hline 加熱収縮率 & $\%$ & 0.07 & 0.18 & $* 2$ \\
\hline 吸水率 & $\%$ & 1.2 & 1.3 & $* 3$ \\
\hline 絶縁破壊強さ & $\mathrm{KU} / \mathrm{mil}$ & 6.8 & 7.0 & $* 4$ \\
\hline 誘電率 & - & 3.5 & 3.5 & *5 \\
\hline 誘電正接 & - & 0.0013 & 0.0014 & $* 5$ \\
\hline
\end{tabular}

${ }^{* 1}:$ ASTM D-882, ${ }^{* 2}: 250^{\circ} \mathrm{C}, 2 \mathrm{hrs}$

${ }^{* 3}$ : ASTM D-570, ${ }^{* 4}:$ ASTM D-149

$* 5$ : ASTM D-150

これらの特徴を生かして, 高密度 FPCや, フィル ムキャリア (TAB) のベースフィルムとして用いられ ている.特に, TAB 分野では, 多ピン化と薄型化の 要請が強まって扔り，高弾性と寸法安定性を兼的備え たユーピレックスーS は, この要請を満足できる材料 として，大きな伸びが期待されている，また，ユーピ レックスーS の寸法安定性をさらに改善したユーピレ ックス-SS も上市しており, 高密度回路の実現に大き く貢献するものと思われる。

このほか, ューピレックスは, 耐放射線性, 耐候 性, 極低温特性など, 優れた特性を有しており, 航空 宇宙分野をはじめ, 核エネルギー分野や超電導分野な どでも注目を笨めている。

また, 厳しい表面平滑性を要求される次世代の垂值 磁気記録分野のベースフィルムとしても, 積極的な開 発が進められている。

\section{宇部興産(株)}

ポリイミド樹脂事業部営業部

齿 107 東京都港区赤坂 1-12-32 アーク森ビル (2) 03-505-9361 


\section{タケネート m-TMXDI および m-TMI}

\section{新規無黄变イソシアネートモノマー}

\section{1. 技術の背票と市場動向}

ポリウレタン樹脂はその優れた物性により年々その 用途を搪大しているが，近年，より高性能ポリウレタ ン樹脂開発のため, 廉価でより耐候性に優れた新規人 ソシアネートモノマーの出現が待望されてきた。

武田薬品工業（株）はアメリカンサイアナミッド社 との長年にわたる共同研究により，このたび $\mathrm{m}$ TMXDI, m-TMI という新しい 2 種類のイソシアネ 一トモノマーを上市した。これら檤従来の無黄変イソ シアネートモノマーに勝る耐候性を有することはもち ろん，従来のモノマー類にはないユニークな性質を有 しており, 全く新しいタイプのポリウレタン樹脂の合 成，用途開発が可能となる。

\section{2. 構造と物性}

m-TMXDI，m-TMI の構造式および一般物性を下 に示す。<smiles>CC(C)(N=O)c1cccc(C(C)(C)C(C)(C)N=O)c1</smiles>

\section{分子量}

244.3

$\mathrm{NCO} \%$

34.4

融点 $\quad\left({ }^{\circ} \mathrm{C}\right) \quad-10$

沸点 $\quad\left({ }^{\circ} \mathrm{C}\right)$

$150 / 3 \mathrm{~mm}$

引火点 $\left({ }^{\circ} \mathrm{C}\right)$

153.3<smiles>C=C(C)C1=CC=CC(C(C)(C)C(C)(C)[O-])C1</smiles>

201.3

20.9

$-$

270

化審法 No.

3-3908

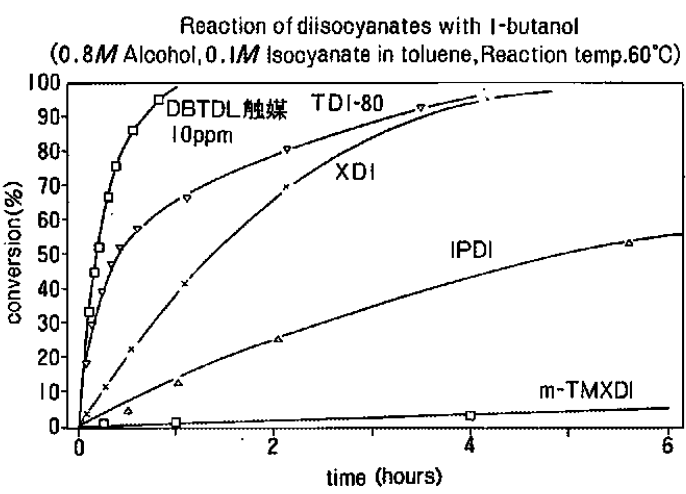

りここの異なった官能基を利用することにより以下に 示す 2 種類の利用法が考えられる.

（1）各種アクリル，スチレンなどのオレフィン類との 共重合によるポリマー鎖中への NCO 基導入

（2）ポリオールなど活性水素化合物とのウレタン化反 応などによる二重結合の導入

これにより， m-TMI の期待される用途として

(1) 各種ポリオレフィン類の改質

(2) 新規ポリオレフィン骨格ポリイソシアネート

（3）ポリヒドロキシ化合物（活性水素化合物）の変性 などがあげられる。

\section{3. 特徵および用途}

m-TMXDI は上市されているモノマーの中では最 も低反応性であり，かつ安全性の高いモノマーであ る.このモノマーを使用したポリウレタン樹脂は以下 のような特徴を有する。

（1）無黄変モノマーの中で最高レベルの耐候性

（2）低粘度プレポリマーの合成が可能であり，UV 樹 脂その他のハイソリッド用途に最適

（3）長い可使時間に加え，スズ触媒の使用により硬化 速度の調整が容易（図）

（4）低温解離型ブロック体 $\left(100^{\circ} \mathrm{C}\right)$ が可能

（5）相溶性に優れ，従来混合不可能とされた各種ポリ マーとのブレンドも可能

（6）室温域，低温域を問わず低モジュラス高伸長度を 保持する

m-TMI は分子内に重合可能な二重結合とイソジ ネート基を共に有する極めてニニークなモノマーであ

\section{武田薬品工業（株）}

化学品事業部㗬業第 4 部

画 103 東京都中央区日本橋 2-12-10

¿ా 03-278-2777

(341 大阪市東区道修町 2-27

zా 06-204-2480 


\section{ダプレン成形材料}

\section{超耐熱性ジアリルフタレート樹脂}

\section{1. 技術の背罟}

電子・電気業界での表面実装技術（SMT）の進歩に 伴い部品に対する耐熱性向上の要求が強まる中で，ダ イソー (旧大阪曹達) はテレ系のジアリルフタレート (商品名ダプレン) をべースとした成形材料を上市し た.このものは PPSを淩ぎ，エコノールやPEEKに 匹敵するハンダ耐熱性を有し，さらに今話題のマルチ ノズル・ミニランナー方式による低コスト成形が可能 なことから熱硬化性スーパーエンプラとして注目を集 めている。

\section{2. 特徵}

（1） $\mathrm{H}$ 種相当の常用耐熱温度 $\left(180^{\circ} \mathrm{C}\right)$

（2）あらゆるハンダ付工程が適用可能

PPS を凌ぎ，エコノール，PEEK に四敵するハン ダ耐熱性を有し, 各種 SMT 用部品に好適.

(3) 高い熱変形温度 $\left(280 \sim 300^{\circ} \mathrm{C}\right)$

（4）優れた耐湿性

高湿度下に畏期間嚗されても特性の低下が極めて少 ない.

（5）流動性が良好

圧縮,トランスファ，射出成形のいずれも可能で, 細密成形に好適。

（6）熱可塑並の低コスト成形が可能

シリンダー安定性が良く，マルチノズル・ミニラン ナー方式の金型の採用で，材料ロスの少ないハイサ イクル成形が可能。

3. 上市グレード

(1) 電子・電気用

$$
\begin{aligned}
& \text { GH-3000：一般用 (非難燃) } \\
& \text { FR-1200：難燃 (UL }=\mathrm{V}-0 \text { 品) } \\
& \text { FR-1300：難燃 (UL }=\mathrm{V}-0 \text { 品), 高耐衝擊 } \\
& \text { FR-4200：難燃, 高流動性 } \\
& \text { FR-4300：難燃, 高流動性, 高耐衝擊 }
\end{aligned}
$$

(2) 食器用

\section{4. 用途}

KW-D2：耐煮沸性，電子レンジに適用可能

耐熱性を要する電子, 電気部品用絶縁材料, 各種素 子の封止材に好適で，特に SMT 対応部品に用途が広 がっている他, 酎熱食器にも使用されている。

(例) コネクター, IC ソケット, ポテンショメータ 一, コイル封止, フィルター封止, コンミテーターな どの電子・電気部品。集団給食用籍, 電子レンジ用容 器などの耐熱食器.

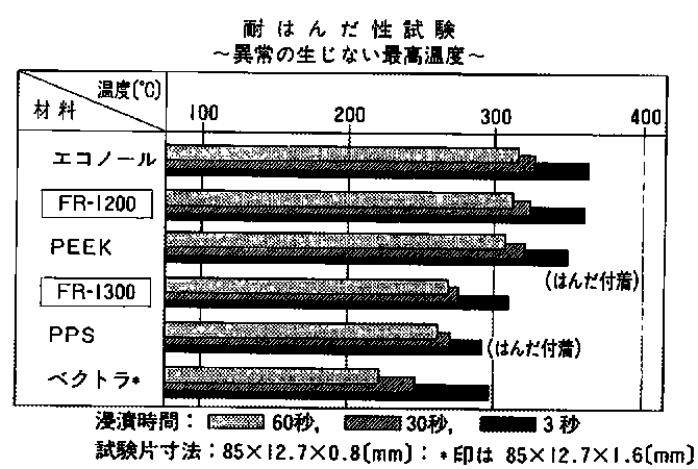

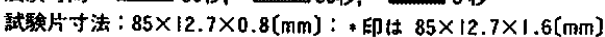




\section{エポセル ${ }^{\circledR} \mathrm{HT}-150$}

\section{耐熱性樹脂}

\section{1. 技術の背暴}

日本触媒化学工業(株) では，成形加工性と两熱性 にバランスのとれた新しい耐熱性樹脂『エポセル® HT-150」を開発した。

現在, 電気・電子, 機械, 自動車, 宇宙・航空機な どの分野に括いて, 熱硬化性, 熱可塑性を含め種々の 耐熟性樹脂が使用あるいは検討されている.

しかしながら，これらの䨖熱性樹脂を成形加工とい う面からみると, 熱可塑性樹脂では溶融温度が高いた め，かなり高温度に加熱する必要があり，エネルギー コスト，寸法精度などに問題がある。また熱硬化性樹 脂では, 樹脂単独で補強材へ含漫させることが困難な ため，溶剤で希釈して含浸し，さらに溶剤を除去して プリプレッグ化する必要があり，硬化に際しても長時 間加熟, 加圧を要するのが現状である。

「エポセル® HT-150』は，上記の問題を軽減ある いは厸拭できる酎熱性樹脂である。

\section{2. 特徵}

（1）常用 $150^{\circ} \mathrm{C}$ 以上の耐熱性を有している.

（2）常温硬化から高温硬化まで幅広い方法が採用でき る.

（3）樹脂単独で低粘度であり，補強材・充填材に対す る濡れ含浸性がよい.

（4）吸水率が低く，かつ耐水性がよい.

3. 用途および用法

補 強 材: ガラス絨維, 炭素瀻維,アラミド織維など 成形方法：フィラメントワインディング，注型，ハン ドレイアップ, レジントランスファー, 連 続成形 (引抜き，押出し，連続穔層)

用途：電気・電子部品, 自動車部品, 航空機部品, 機械部品など各種工業部品

また，プレス成形やインジェクション成形用に，充 填材・補強材を配合した成形材料，あるいは Bステー ジ化を施してプリプレッグとすることができる.

さらに, 澍脂粘度が低いため, 樹脂単独あるいは充 堤材を配合して，電気・電子部品を封入注型すること もできる.

その他, ワニス，コーティング材としても用いられ る.

このような『エポセル ${ }^{\circledR} \mathrm{HT}-150$ 」は，作業性，生 産性を大幅に改良し, 沉用的加工方法でしかも短時間 に成形加工できる新しい耐熱性樹脂である。
エポセル® HT-150 の基本物性

\begin{tabular}{|c|c|c|c|}
\hline & & 注型品 & 丧屬品 \\
\hline ガラス含有量 & (\%) & - & 68 \\
\hline 曲げ強度 & $\left(\mathrm{kg} / \mathrm{mm}^{2}\right)$ & 10.9 & 52 \\
\hline 曲げ弾性率 & $\left(\mathrm{kg} / \mathrm{mm}^{2}\right)$ & 477 & 2,110 \\
\hline 引張り強度 & $\left(\mathrm{kg} / \mathrm{mm}^{2}\right)$ & 6.0 & 32 \\
\hline 引張り弾性率 & $\left(\mathrm{kg} / \mathrm{mm}^{2}\right)$ & 465 & 1,640 \\
\hline 引张り伸び率 & $(\%)$ & 1.5 & 2.1 \\
\hline 層間剪断強度 & $\left(\mathrm{kg} / \mathrm{mm}^{2}\right)$ & - & 4.5 \\
\hline 蘩変形温度 & $\left({ }^{\circ} \mathrm{C}\right)$ & 180 & - \\
\hline ガラス転移点 & $\left({ }^{\circ} \mathrm{C}\right)$ & - & 245 \\
\hline Barcol 硬度 & $(934-1)$ & 52 & - \\
\hline
\end{tabular}

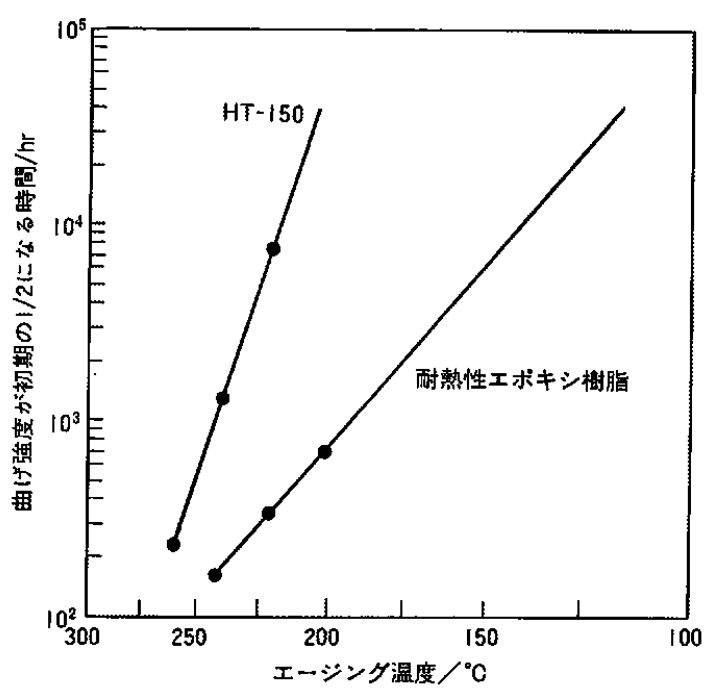

注）耐熱性エボキシ薣脂：TGDDM/DDS

TGDDM：テトラグリシジルシアミノシフェニルメタン DDS : シアミノシフェニルスルホン

注型板による耐熱性の寿命予測

\section{日本触媒化学工業(株)}

大阪樹脂営業部

业 541 大阪市中央区高麗橋 4-1-1（興銀ビル）

206-223-9220 FAX 06-202-1765

東京支社

１08 東京都港区三田 3-11-36（三田日東ダイビル）

× 03-798-7071（代） FAX 03-798-7097 


\section{アクアリック ${ }^{\circledR} \mathrm{CS}$}

\section{変性ポリアクリル酸ナトリウム架橋体}

\section{1. 概要}

アクアリック CS は，ポリアクリル酸系吸水性樹 脂の特長である高吸水能・耐熱性を保ちながら，耐多 価金属イオン性を改良したユニークな吸水性樹脂であ る.

ポリアクリル酸系吸水性樹脂は，吸水能力などに優 れており，紙おむつなどに広く使用されているが，力 ルシウムやマグネシウムなどの多価金属イオンに対す る耐久性が劣るという欠点があった。したがって，多 価金属イオンを含む水（海水，地下水など）と長期間 接触すると，吸水能力が経時的に低下してしまうた め，土木用や工業用などの長期間にわたって使用され る分野には使用できなかった。アクアリック® ${ }^{\circledR} \mathrm{CS}$ は, このようなポリアクリル酸系吸水性樹脂の欠点を改良 した新規な吸水性樹脂である。

\section{2. 特長}

（1）多価金属イオンに対して安定であるので，地下 水，海水，液体肥料などのカルシウムやマグネシウ 厶を含む水溶液中でも吸水倍率の経時的変化は小き く，優れた吸水能力を示寸(図 1).

（2）而熱性に優れているので，ゴム加硫時のように加 工時に高温になっても, 揮発分を発生したり, 性能 が劣化することは任とんどない.

（3）吸水・乾燥を繰り返しても，吸水倍率の低下はほ とんどない。

（4）粉砕が容易であるので， $3 \mathrm{~mm}$ 程度の粒状から, $10 \mu \mathrm{m}$ 程度の微粉末状まで, 粒子径を小さくする ことが可能である。また，さらに粒子径の大きなも のも可能である。

3. 用途

（1）水膨潤性ゴム（土木用シール材）

アクアリック® CS をゴムに混練すると，そのゴム は, 塩水中でも優れた膨潤能力を示し, 止水能力に優 れているので, トンネルのセグメント止水材, 七ュー ム管用止水リング，止水板などに使用されている。

（2）光・電力ケーブル用止水郕

ケーブルが損甥して，水がケーブル内に浸入した場 合,ケーブル内を水が走らないように,アクアリック® CS を充㙉する方法が考案されている。

（3）その他

モルタル・コンクリート改質刻, 農園芸用保水剂,

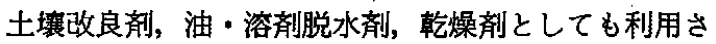
れようとしている。

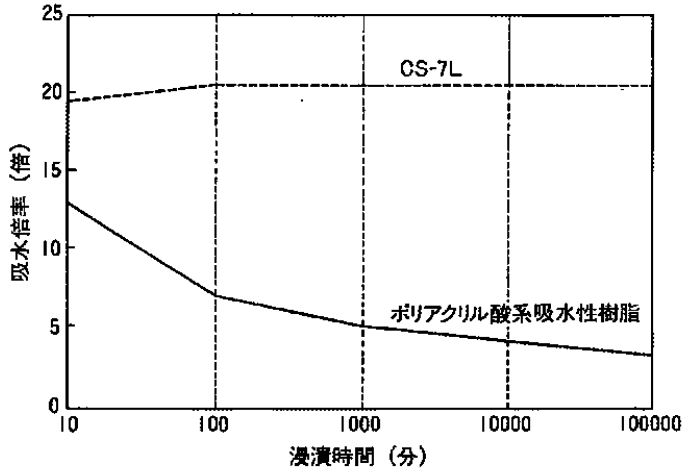

図 1 吸水犃率の経時変化(合成海水)

表 1 アクアリック® CS の性状

\begin{tabular}{|c|c|c|c|}
\hline 項 & CS-7 L & $\mathrm{CS}-7 \mathrm{M}$ & CS-7 S \\
\hline 観 & $\begin{array}{l}\text { 淡黄色不定 } \\
\text { 形塊状 }\end{array}$ & 淡黄色不定 & 淡黄色微粉 \\
\hline $\begin{array}{l}\text { 吸水倍率 }(\mathrm{g} / \mathrm{g}) \\
\text { 脱イオン水 } \\
3.5 \% \text { 食塩水 } \\
\text { 合成海水 }\end{array}$ & $\begin{array}{c}130 \sim 150 \\
17 \sim 20 \\
16 \sim 20\end{array}$ & $\begin{array}{c}130 \sim 150 \\
17 \sim 20 \\
16 \sim 20\end{array}$ & $\begin{array}{c}130 \sim 150 \\
17 \sim 20 \\
16 \sim 20\end{array}$ \\
\hline 平均粒子径 & $1 \sim 2 \mathrm{~mm}$ & $50 \sim 200 \mu \mathrm{m}$ & $10 \sim 30 \mu \mathrm{m}$ \\
\hline $\mathrm{pH}$ & $6 \sim 8$ & $6 \sim 8$ & $6 \sim 8$ \\
\hline 主な用途 & $\begin{array}{l}\text { 農圊芸用保 } \\
\text { 水刘, 土壤 } \\
\text { 改良剤, 土 } \\
\text { 木用止水剮 }\end{array}$ & 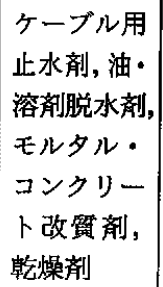 & $\begin{array}{l}\text { 水膨潤性ゴ } \\
\text { ム, ケーブ } \\
\text { ル用止水剂, } \\
\text { プラスチッ } \\
\text { ク改䝷剂 }\end{array}$ \\
\hline
\end{tabular}

\section{日本触媒化学工業（株）}

吸水性樹脂製品開発部

本 社

541 大阪甫中央区高麗橋 4-1-1（興銀ビル)

\% 06-223-9214 FAX 06-201-3716

東京支社

(108 東京都港区三田 3-11-36（三田日東ダイビル） 203-798-7071（代） FAX 03-798-7097 


\section{エポラス ${ }^{\circledR}$}

\section{透明調新成形材料}

\section{1.はじめに}

エポラスは，日本触媒化学工業（株）が開発した， 新規成形材料である. プレス成形法を用いて, 透明感 のある表面性良好な光沢のある成形品が得られる。

\section{2. 特徽}

（1）外観：無着色の 5 ミリ厚成形品で, 全光線透過率 が 30\% あり，透明性が良好である。また，表面平 滑性, 光沢とも良好である。

（2）耐水性：成形品の両面煮沸 300 時間で, クラッ ク,ふくれ，反りなどの久陌はなく，また，色の変 化は非常に小さく, 全光線透過率もほとんど低下し ない.

（3）耐熟性：熱変形温度が $200^{\circ} \mathrm{C}$ 以上あり，十分な耐 熱性を有している，また，着火煙草を置いておいて も外観の変化はない。

（4）強度：表のとおりである. 弾性率が大きいので変 形しにくく重量感がある。

（5）耐污染性：表のとおりで良好であり 特に，染毛 㓮についても良好であるので, 洗面化粧台への使用 もできる.

（6）着色性：良好で，いろいろな色に自由に着色でき る.

（7）成形性：140 ${ }^{\circ} \mathrm{C} て ゙ ， 10$ ミリ厚が 7 分程度で成形で き, 生産性は非常に良好である。

\section{3. 用途}

バスタブ, 洗面化粧台, カウンタートップなどの水 回り品, ホテルグッズ, 卓上小物などの装飾品, 工芸 品など, その他, 限定されることなくいろいろな用途 への展開が可能である。
エポラスゆ 6015-142 データ

\begin{tabular}{|c|c|}
\hline 項 & データ \\
\hline 全光線透過率 \%/5 mm 無着色 & 30 \\
\hline 光 沢 $60^{\circ} \sim 60^{\circ}$ & 90 \\
\hline $\begin{array}{cc}\text { 耐 水 性 } & \Delta E \\
& 100 \mathrm{H} \\
& 200 \mathrm{H} \\
& 300 \mathrm{H}\end{array}$ & $\begin{array}{l}1.0 \\
1.4 \\
2.1\end{array}$ \\
\hline 比 & 2.1 \\
\hline 成形収縮率（\%) & 0.3 \\
\hline 熱変形温度 $\left({ }^{\circ} \mathrm{C}\right)$ & $200<$ \\
\hline 耐熱性（着火煙草 5 分放置） & 変化なし \\
\hline バーコール硬度 $(934-1)$ & 60 \\
\hline 鉛筆硬度 荷重 $1 \mathrm{~kg}$ & $3 \mathrm{H}$ \\
\hline 耐摩耗性 荷重 $500 \mathrm{~g}$ (mg) & 140 \\
\hline $\begin{array}{ll}\text { 強 度 } & \text { 曲げ強度 }\left(\mathrm{kg} / \mathrm{mm}^{2}\right) \\
& \text { 曲げ弾性率 }\left(\mathrm{kg} / \mathrm{mm}^{2}\right) \\
& \text { 引張強度 }\left(\mathrm{kg} / \mathrm{mm}^{2}\right) \\
& \text { 衝晎強度 }\left(\mathrm{kgcm} / \mathrm{cm}^{2}\right) \\
& \text { アイゾットフラットワイズ }\end{array}$ & $\begin{array}{r}8 \\
1,600 \\
3 \\
5\end{array}$ \\
\hline 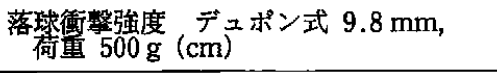 & 40 \\
\hline 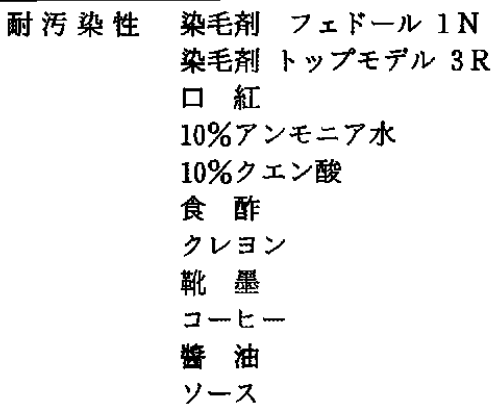 & $\begin{array}{l}\text { 変化なし } \\
\text { 変化なし } \\
\text { 変化なし } \\
\text { 変化なし } \\
\text { 変化なし } \\
\text { 㚆化なし } \\
\text { 変化なし } \\
\text { 変化なし } \\
\text { 変化なし } \\
\text { 変化なし } \\
\text { 変化なし }\end{array}$ \\
\hline
\end{tabular}

*成形条件・温度 $140 / 130^{\circ} \mathrm{C} \cdot$ 圧力 $50\left(\mathrm{~kg} / \mathrm{cm}^{2}\right)$ - 加圧保持時間 7 分・厚み $10 \mathrm{~mm}$

*測定条件・JIS K 6911，6902など

\section{日本触媒化学工業 (株)}

\section{大阪樹脂営業部}

亚 541 大阪市中央区高麗橋 4-1-1（興銀ビル）

c 06-223-9220 FAX 06-202-1765

東京支社

⑩8 東京都港区三田 3-11-36（三田日東ダイビル）

803-798-7071（代） FAX 03-798-7097 


\section{マルカリンカー}

\section{p-ビニルフェノールポリマー}

1976 年にpービニルフェノールポリマーの工業化技 術が丸善石油 (株) によって開発されて以来, 本ポり マーは国内外の注目を集め, 構造材料や機能材料とし て耐熱性複合材料, 感光性樹脂, コーティング材料, 接着剤，金属表面処理剂などに応用されて用途を㹡大 してきた.

本ポリマーは丸善石油(株) より丸善石油化学(㧣) に移管され，名称もマルカリンカー M, MB（旧称レ ジン $\mathrm{M}, \mathrm{MB}$ ) となって現在に至っている.

マルカリンカーは $p$-ビニルフェノールを㲦とする 活性なフェノール基を有する機能性高分子であり，ホ モポリマーであるマルカリンカー M, 乱よ゙その臭 素化物であるマルカリンカーMBを中心に種々のビニ ルフェノールとの共重合物が製造されている（図）。

\section{1. 特長}

マルカリンカーは,フェノールノボラックに似た構 造を持ったフェノールの一種であるが, ノボラック樹 脂とは異なってビニル重合による規則的な構造および 比較的高い重合性に起因する耐熱性，可撓性に優れた 特長がある。

(1) マルカリンカー M は, 類似構造のポリスチレン にはない高い反応性を持ち, また縮合型フェノール 樹脂に比べて安定性が高く，温和な条件で各種の誘 導体を合成することができる。

（2）マルカリンカー M の反応性は活性なフェノール 性水酸基との縮合あるいは付加反応および芳香族と の茞換反応がある。

（3）マルカリンカー MB はマルカリンカー M の鼻絷 化誘導品で, マルカリンカーＭ に難燃性を加味し た性質を有し，反応性難燃郕として用いられる。

2. 仕棣

マルカリンカー $\mathrm{M}\left(M_{\mathrm{W}}: 2,000 \sim 30,000\right)$

微粉末 $10 \mathrm{~kg}$ 袋詰

(用途別，分子量別に 7 種のグレードがある)

マルカリンカー MB ( $\left.M_{\mathrm{W}}: 6,000 \sim 7,000\right)$

微粉末 $10 \mathrm{~kg}$ 袋詰

(奥素化品については 1 グレードのみ)

\section{3. 応用分野}

（1）エポキシ樹脂硬化剤（積層板，成形材料）

（2）感光性材料（印刷用 PS版，マイクロフォトレジ スト、エッチングレジストなど)

（3）難燃性材料（プリント配線基板，成形材料，接着 斉など)

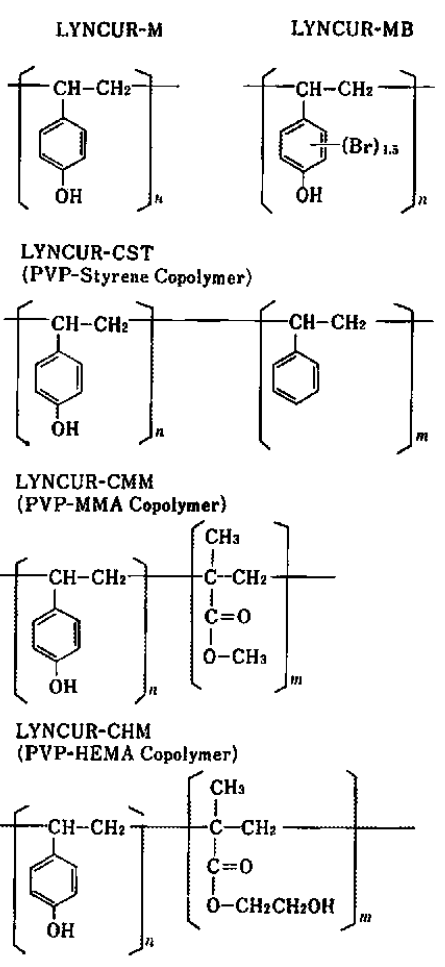

表 1

\begin{tabular}{|c|c|c|}
\hline 項目銘 唡 & $\mathrm{P}^{\text {マルカリンカー }}$ & $\begin{array}{l}\text { マルカリン } \\
\text { カーMB }\end{array}$ \\
\hline 水酸基当量 & 約 120 & 約 246 \\
\hline 平均分子量 $\left(M_{\mathrm{w}}\right)$ & $2,000 \sim 30,000$ & $6,000 \sim 7,000$ \\
\hline 軟化点 $\left({ }^{\circ} \mathrm{C}\right)$ & $160 \sim 200$ & $190 \sim 220$ \\
\hline 引火点 $\left({ }^{\circ} \mathrm{C}\right)$ & 308 & 引火せず \\
\hline 真密度 $(\mathrm{g} / \mathrm{m} l)$ & 1.2 & $1.8 \sim 2.0$ \\
\hline 水分含有量（\%） & 3 以下 & 約 1 \\
\hline モノマー含有量（\%) & 1 以下 & 1 以下 \\
\hline オリゴマー含有量(\%) & 3 以下 & 3 以下 \\
\hline 臭素含有量（\%） & - & $47 \sim 52$ \\
\hline
\end{tabular}

（4） キレート樹脂

（5）金属表面処理斉

\section{丸善石油化学 (株)}

(104 東京都中央区八丁堀 2-25-10

\& 03-552-9364 FAX 03-555-0768 


\section{TECHMORE ${ }^{\circledR}$}

\section{高耐熱性エポキシ樹脂}

三井石油化学は, 電子機器の小型, 多機能化を支え る実装部品, およびプリント配線板の要求に対応し た，新しい高耐熱性エポキシ樹脂「TECHMORE」 を開発した。

代表的な実装部品である IC は，1チップ化による 多ピン化と，大チップ化の高機能化が進んでいる，一 方, 実装部品を搭載するプリント配線板は, 実装の高 密度化と IC の多ピン化に対応した, 多層配線板が伸 びている.

実装部品およびプリント配線板から要求される品質 は, 優れた耐熱性, 接着性と靭性(粘り強さ) であ る.ところがエポキシ樹脂は, 耐熱性を追求していく と硬く (高架橋密度) なるばかりで, 接着性も鞀性も 低下する.したがって耐熱性もあり勒性もある高性能 エポキシ樹脂か゚, これらの高付加価值分野で主力にな ると予想される.

\section{1. 物性と特徵}

(1) TECHMORE VG3101

既存の原料ソースにこだわることなく, 樹脂構造ま でさかのぽった分子設計によって生み出された, 高耐 熱性三官能エポキシ樹脂. 優れた耐熱性と機械的強度 があり, しかもガラス転移温度 $\left(T_{\mathrm{g}}\right)$ に対する曲げ弾 性率が低い.

高集積度の IC 封止材が必要とする内部応力 (パッ •ケージラック) の低隇, および而熱性の向上といった 品質要求に応えることができる.

(2) TECHMORE VF2801

VG3101 の特徵を活かした, 新規多官能骨格を持つ 難然エポキシ樹脂, 成長の著しい 4 15 層の, 而熱多 層プリント配線板用に品質設計を行った. 既存の FR 4 積層板で使用中の硬化剂との組合せで, ガラス 転移温度 $190^{\circ} \mathrm{C}$ 耐熱レベルを達成できる。

また, 実装の高密度化から, プリント配線板が必要 とするハンダ耐熱性, 銅䇴接着強度, 機械強度などの 品質要求に応えることができる.

\section{2. 用途}

IC カード、コンピューターの積層板, 自動車分野 など.

\section{3. 将来の動向}

TECHMOREは, 電気・電子分野の成形材料, CFRP 複合材料および接着材料などの耐熱性を必要 とする新しい用途分野での開発が期待される.

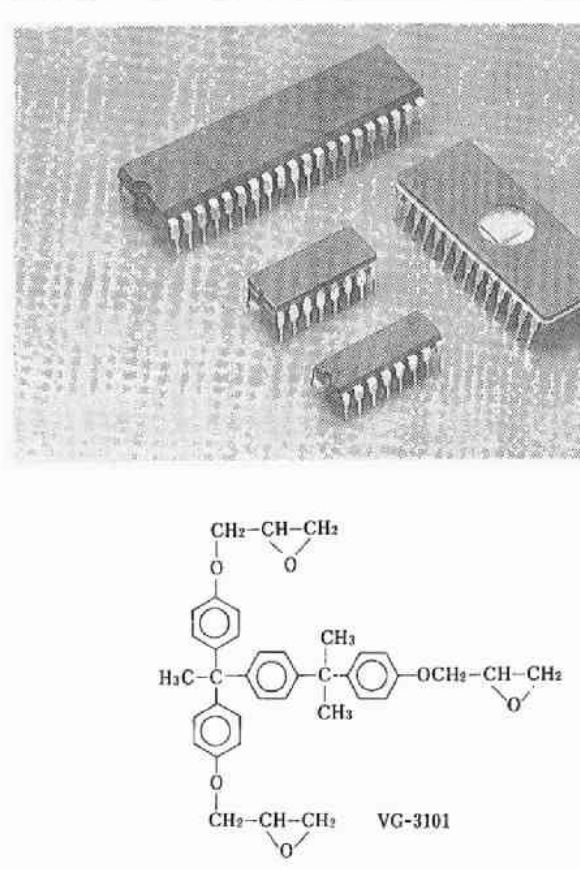

図 1 構造式

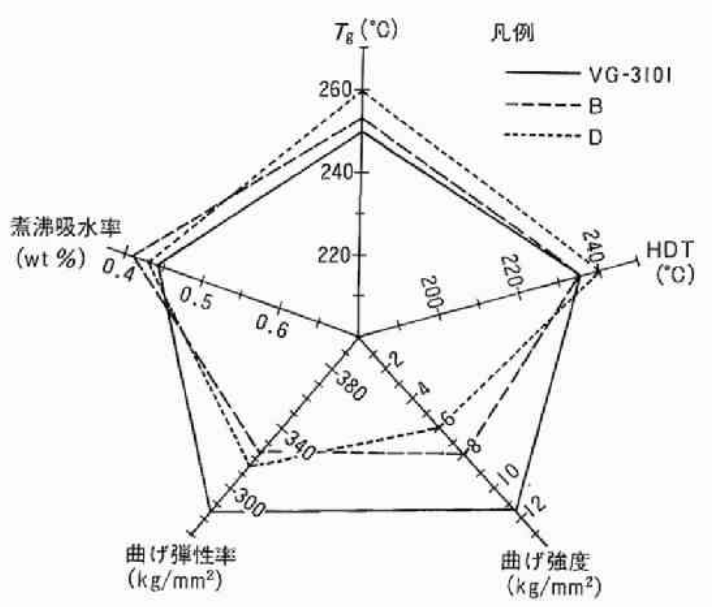

図 2 固形エポキシ樹脂系の硬化物性

\section{三井石油化学工業（株）}

\section{エポキシ事業部}

本社

严100 東京都千代田区霞が関 3-2-5(霞が関ピル)

z: 03-581-2637 


\section{ユニベックス}

微粒球状熱硬化性フェノール樹脂

\section{1. 技術の背景}

フェノール樹脂は最も歷史の旧いプラスチックであ りながら, 現在でも代表的な熱硬化性樹脂の一つとし て，種々の分野で利用されている．

ユニチカは最近，新規な面濁重合プロセスで製造さ れる高機能の微粒球状フょノール樹脂「ユニベック ス」を開発した. ユニベックスは硬化剈の添加を必要 としない固体状の一段法フェノール樹脂である.

固体状フェノール樹脂を製造する方法としては，バ ルク重合を行った後, 急冷して粉砕することにより製 造する方法が知られていたが, 懸濁重合プロセスは, 従来法と比較して,

(1) ラージスケールでの反応が可能なこと

(2) 連続的な操作, 自動化が容易なこと

(3) 樹脂の品質が安定していること

(4) 製造時に粒径操作が容易なこと

(5) 樹脂銘柄のきり替えが容易なこと

などのメリットを有する合理的プロセスであり，この プロセスを利用して製造されるユニベックスは, 種及 な化学的特性, 形状特性を有する新規な高機能性樹脂 として位置付けられる。

\section{2. 銘柄および特幑}

ユニベックスの銘柄としては，熱反応性を有する $\mathrm{S}, \mathrm{N}, \mathrm{UA}$ の各タイプ, 硬化して熱反応性を有さない C タイプがあり，いずれも，独立した微小球状の粒子 である. その中で UA タイプは, その形状特性と熱 反応性を利用した焼結成形が可能な樹脂である. 熱硬 化性樹脂の焼結成形は，ユニベックスによって，初め て可能となった。ユニベックスの燒結成形により, 連 続気孔を有する多孔質のフェノール樹脂成形体の気孔 径は, ユニベックス UA シリーズの粒子径（10～800 $\mu \mathrm{m}$ ま ，任意のサイズが選択可能）を選ぶことによ り，自由にコントロールできる。

さらに,この多孔質フェノール樹脂成形体を, $50^{\circ} \mathrm{C} / \mathrm{hr}$ の昇温速度で $1000^{\circ} \mathrm{C}$ まで昇温してカーボン化 すれば，多孔質のグラッシカーポン成形体が得られ る。グラッシカーボンは, アモルファスな硬質カーポ ンであり, その耐薬品性, 耐熱性, 高硬度強度, 電気 伝導性を利用した用途分野の開発が期待される新素材 である。ささらに，優れた保存安定性を有する未硬化夕 イプの各種ユニベックス $(\mathrm{S}, \mathrm{N})$ の広範囲の用途開発 が期待される。

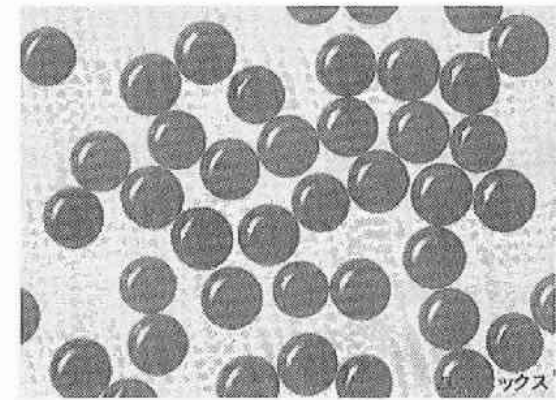

\section{3. 用途開発展望}

・プラスチック、ゴムの改質

・超硬工具, セラミック, 焼結金属のバインダー, 気 孔形成

・フィルム・缶へのコーテング剤, 表面改質

・ガラス織維織物，炭素繊維織物への含浸

・塗料，接着剤の改質

・各種摺動材の改質

・固体潤滑剤, ショット材, 各種スペーサー

- 自動車, 電気, 電子部品の成形材料

・焼結成形体 (フィルター, インクローラー, 散気 板, 加温板)

・微小球状グラッシカーボン（導電性耐摩耗性フィラ 一. 表面改質冎)

・グラッシカーボン成形体 (電極, セパレーター, 摺 動材, フィルター, 吹込管)

\section{ユニチカ (株)}

新規開発本部ユニベックス開発部

大阪本社

可 541 大阪市中央区久太郎町 4-1-3

జ $06-281-5249$

東京本社

区103 東京都中央区日本橋室町 3-4-4（JP ピル）

¿ 03-246-7695 


\section{旭化成高潤滑性ポリアセタールテナック ${ }^{\circledR}$ LA501}

ポリアセタール

\section{1. 技術の背量}

旭化成は世界で唯一「ホモポリマーとコポリマーの 両者を併産する」ポリアセタール樹脂メーカーであ る。佸者を当社独自の製造技術で生産している。 そこで, 当社はホモポリマーとコポリマー両者の特徵 を生かして市場展開すると同時に，独自の製造技術を 利用して従来工業的に実現していない「ポリアセター ル樹脂のポりマー骨格の改変」という新領域の技術開 発を進めている。

一方，ポリアセタール樹脂は潤滑特性に優れたエン ジニアリング樹脂であり，替動機構部品材料として広 く使用されているが，近年の特に電気・電子機器の活 発な新製品開発の中で，その潤滑性能の向上が強く望 まれている。

「テナック®LA501」はこのような当社の技術的背景 とマーケットニーズによって開発された高閵滑性のポ リアセタールの樹脂である。

\section{2. 分子構造上の特徵}

ポリアセタール樹脂の中でもホモポリマーはコポリ マーに比べて潤滑特性に優れている。「テナック® LA501」はホモポりマーの潤滑特性向上を组ってポり マーデザインしたもので, その分子構造は，ポリマー 骨格改変技術により，「ホモポリマーの分子末端に潤 滑官能性ポリマーを化学結合した構造」になってい る.すなわち「第三の構造のポリアセタール樹脂」と もいえるプロックコポリマー型の新しい分子構造であ ることが大きな特徵である。

\section{3. 物性の特徵と用途}

ブロックコポリマー型ポリアセタール樹脂「テナッ ク®LA501」は摺動時の相手の材質にかかわらず，優 れた潣滑性（低摩擦係数・低摩耗性）を発揮する，以 下に特徴的項目を挙げる。

(1) 特に, 従来不適当とされていたポリアセタール樹 脂を相手とした摺動時の潤滑性能に優れる。

(2) 無給油での潤滑性に優れており，しかもその性能 を半永久的に持続する。

（3）機械的特性はポリアセタール樹脂一般グレードと ほ汇同レベルである。

(4) 通常のポリアセタール樹脂と同様に成形できる.

このような特徴から「テナックロLA501」を摺動機 構部品材料として用いることにより, 耐久性の向上 （運転トルクの長期安定化）グリスレス化・起動トル ク低減・ノイズ低滅・ベアリングレス化・メンテナン

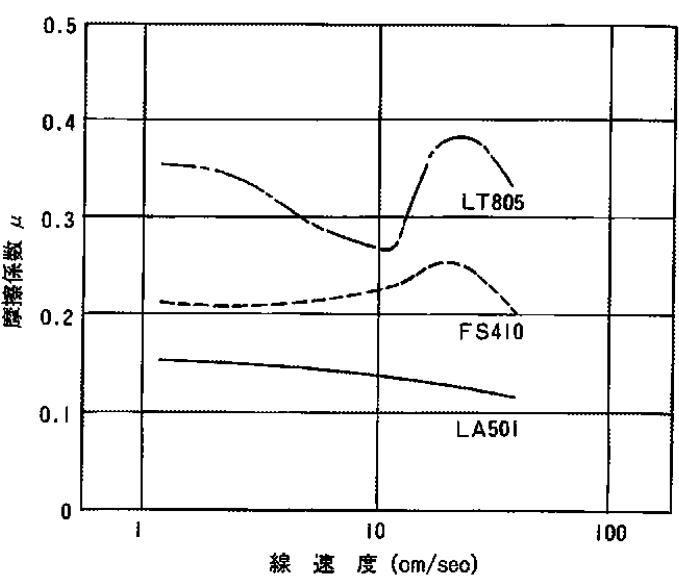

(条件) 相手材 POM ホモポリマー 面圧 : $2 \mathrm{kgf} / \mathrm{cm}^{2}$ 無潤滑 周囲温度 $23^{\circ} \mathrm{C}$

图 1 テナック 8 LA501 の摩擦挙動（スラスト型）

\begin{tabular}{|c|c|c|}
\hline \multirow{2}{*}{$\begin{array}{l}\text { テナック } \\
\text { グレード }\end{array}$} & 線摩耗量 $\left(10^{-4} \mathrm{~g} / \mathrm{km}\right)$ & \multirow{7}{*}{ 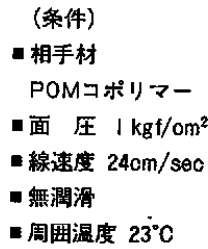 } \\
\hline & 806040200020406080 & \\
\hline LA50I & & \\
\hline 5010 & & \\
\hline C4510 & & \\
\hline$F \$ 410$ & & \\
\hline LT805 & & \\
\hline
\end{tabular}

(注)テナック-5010ＰOMホモポリマー テナック・04510 POMコポリマー テナック-FS410 フッ秦樹脂添加POM テナックーLT805 閏滑郕オイル添加POM

図 2 テナックQLA501 の涌摩耗性（スラスト型）

スフリー化などが可能であり，既実續例もある。 (用途例) ギア・カム・軸受 (ベアリング代替)・ロー ラー・スライドレバー・スイッチ部品など

\section{旭化成工業(株)}

特殊樹脂事業部

エンジニアリング樹脂販売第一部

西100 東京都千代田区有楽町 1-1-2 日比谷三井ビル 2803-507-2561 5

樹脂技術センター エンジニアリング樹脂グループ 函 210 川崎市川㱦区夜光 1-3-2 2074-271-2446 


\section{UBE PPS}

\section{ポリフェニレンサルファイド}

\section{1. 技術の背景と市場動向}

エンジニアリングプラスチックは，さまざまな分野 で使用されていますが, 近年, 特に機能部品の要求特 性が高度化, 多様化するなかで, 従来の汎用エンジニ アリングプラスチックよりさらに優れた特性を持つ樹 脂を求める動きが大きくなってきました，てのなか でホポリフェニレンサルファイド樹脂 (PPS 樹脂) は その優れた機械的強度・耐熱性・耐薬品性・寸法安定 性などにより，第 6 の汎用エンジニアリングプラスチ ックとして注目を浴び，ここ数年急速に需要量が増加 しています。

PPS 樹脂には，大きく分けてリニアタイプと熱架 橋タイプがありますが, UBE PPS はこの両者の特性 を兼坟備えたタイプの原料レジンを用い，ナイロンを 中心としたプラスチックの総合メーカーとしての 30 年余の経験とコンパウンド技術を生かして開発したも のです

\section{2. 構造と物性}

PPS 樹脂は

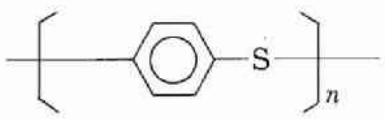

の構造を持つ結晶性の熱可塑性樹脂です この分子構 造により PPS 樹脂はいくつかの優れた特性をもって います。

まず，そのままで UL 燃焼性規格で V-0， $5 \mathrm{~V}$ と最 高の難燃性を有しています。また，耐薬品性・耐熱 性・寸法安定性などが優れています

ただ, PPS 樹脂そのものは剛直な分子構造を持つ 結晶性の熱可塑性樹脂ですので，そのままでは割れや すいという性質があります。このため PPS 樹脂は一 般的にガラス瀻維の補強材や無機充填材などで強化改 質して用いられています。

\section{3. 特徵と用途}

UBE PPS はこのような特性を生かし，さまざまな 分野に使用されています。

まず, 耐熱性に優れ $220 \sim 240^{\circ} \mathrm{C}$ ま゙連続して使用 できるため, 加熱調理器具の部品やランプソケットお よび自動車の排ガス循環バルブなどに使用されていま す。これらには難燃性も必要です。

有機溶剂雲囲気・ $200^{\circ} \mathrm{C}$ までの使用に耐えることか ら, 薬品や熱水・スチーム用バルブ・ポンプ部品など

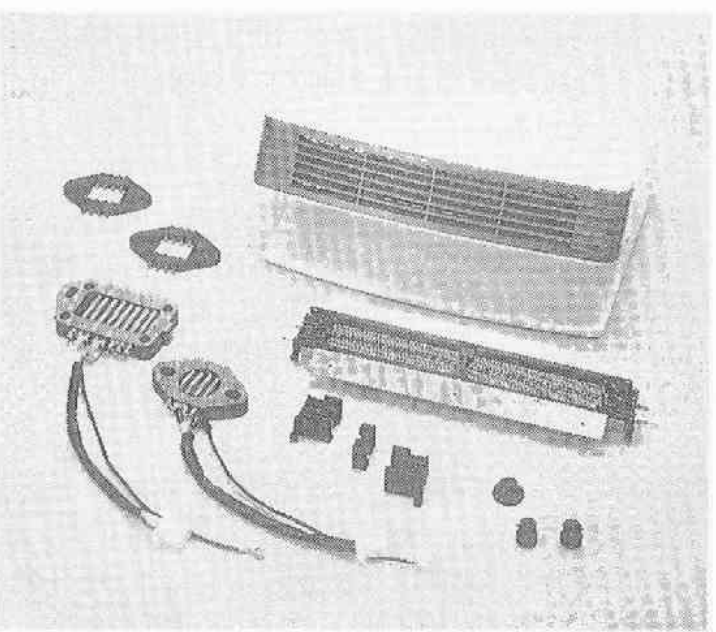

UBE PPS

に使用されています。

また, 高温下でも優れた機械的強度を持ち, 線撷張 係数が小さいので，アルミダイカスト部品の代わりに 用いられています。

高温・高湿下で優れた寸法安定性を示し, 電気的特 性や難燃性に優れているため, 電気・電子・精密機器 部品に使用されています，流動性が良く，成形加工性 にも優れていますが，特に，コネクター・コイルボピ ン・ICソケット・時計地金などの小型部品に使用され ています。

そのほか, 合成樹脂製容器包装規格試験に合格して おり，食品衛生の面でも無害で安全です.

PPS 樹脂はその優れた特性から, 電気電子部品, 自動車・輸送機分野，機械部品などに幅広く使用され ておりますが，さらに多くの可能性を秘めた樹脂であ るとの認識に立ち, ユーザーの皆様の御要望に合わせ たグレード開発を進めております。

\section{宇部興産 (株)}

東京本社 機能性樹脂事業本部開発部 洜107 東京都港区赤坂 1-12-32 アーク森ビル జా 03-505-9353 


\section{フォートロン KPS}

\section{ポリフェニレンサルファイド}

当社は線状高分子量タイプの PPS 樹脂の開発に成 功し, 昭和 62 年 4 月から 3,000 トン/年のプラントを 稼動させている.

フォートロン KPS の製造工程は，新しい重合方法 により経済的に線状高分子とするもので，低分子量か ら超高分子量のものまで自由に生産できる．重合も精 度良くコントロールされて扔り，樹脂品質にばらつき の少ないことも特徵である.

フォートロン KPS について当社は, 欧州でへキス ト．米国でへキスト・セラニーズ，日本でポリプラス チックスの各社と提携して扔り，「フォートロン」の 統一商標で世界的な供給体制を整えている.

フォートロン KPS の特徴は, (1)破断伸度が大き い, (2)衝擊強度が高い, (3)ウェルド強度が高い, (4)流 動性がよい，(5)溶融時の熱安定性が高い，(6)調色が容 易，(7)イオン性不純物が少ないことである.フォート ロン KPS の単独成形の物性と強伸曲線を表 1 と図 1 に示す.

射出成形用コンパウンドは従来品と比べ，伸び，た わみ, アイゾット衝撃強度, ウェルド強度, バリなど が大幅に改良されている.

押出しシート．2 軸延伸フィルムおよびモノ、マル チフィラメントの用途の開発も行っている.

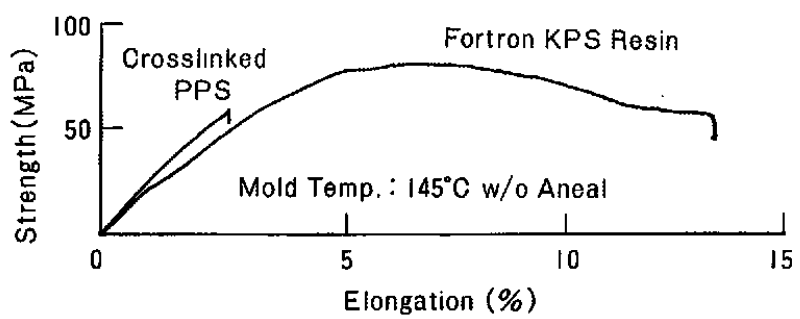

図 1 Stress Strain Curve of Fortron KPS Resin
衰 1 Mechanical Properties of Fortron KPS Resin

\begin{tabular}{|lr|r|r|}
\hline & \multicolumn{1}{|c|}{$\begin{array}{c}\text { Fortron } \\
\text { KPS Resin }\end{array}$} & $\begin{array}{c}\text { Crosslinked } \\
\text { PPS }\end{array}$ \\
\hline T.S. & $(\mathrm{MPa})$ & 80 & 50 \\
Elongation (\%) & 12 & 2 \\
F.S. $\quad(\mathrm{MPa})$ & 110 & 90 \\
F.M. & $(\mathrm{MPa})$ & 3,450 & 4,200 \\
Izod & $(\mathrm{w} / \mathrm{o} \mathrm{notch})$ & 90 & 6 \\
H.D.T. & $\left(\begin{array}{c}(\mathrm{MPa} / \mathrm{cm}) \\
\left({ }^{\circ} \mathrm{C}\right)\end{array}\right.$ & 108 & 108 \\
\hline
\end{tabular}

*Mold Temperature : $145^{\circ} \mathrm{C}$

\section{KPS 部}

\section{吳羽化学工業 (株)}

本社

⑩3 東京都中央区日本橋堀留町 1-9-11

จ 03-662-9611 


\section{スミライト ${ }^{\circledR}$ TFC $33 \mathrm{~A} 1,13 \mathrm{~A} 1$}

ポリイミド

\section{1. 技術の背景と市場動向}

近年のエレクトロニクスの進歩に伴い, 電子機器の 高密度実装は急速に進んでおり，機器内空間はフレキ シプルプリント配線板を有効に利用することにより， 軽薄短小化と高機能化が実現されている。最近では,さ らにいっそうの細線化の技術要求が強くなってきた.

従来のフレキシプルプリント配線板は, ベースフィ ルムと銅䇴とを接着剛を用いてラミネートすることに より製造している。しかしこの場合，基板の耐熱性は 接着剤の而熱性により決定され，高周波域での電気特 性もよくなかった.

住友ベークライトでは，このような要求に応えるた めに，接着剤を用いずに耐熱性に優れたポリイミドを 直接銅䈃と一体化させた二層フレキ,「スミライト ${ }^{\circledR}$ TFC $33 \mathrm{~A} 1$ および $13 \mathrm{~A} 1 」$ を開発した。

「スミライト ${ }^{\circledR} \mathrm{TFC} 33 \mathrm{~A} 1$ および $13 \mathrm{~A} 1 」 の$ 製造にあ たっての技術ポイントは二つある。

(1)特殊なポリイミド樹脂の開発

一般的なポリイミド樹脂では線膨張係数が銅䈃のそ れに比べて 2 3 倍大きいため, 雨者を直接積層する と接着界面に応力が発生し, 製品がカールしたり, シ ワが発生したりする，そこで「スミライト ${ }^{\circledR} \mathrm{TFC}$ $33 \mathrm{~A} 1$ および 13A1」ではポりイミドの分子構造に工 夫を加え，線膨張係数を銅のそれと同一レペルにして 応力発生を抑えることに成功した。

(2)連続生産技術

ポリイミド屡の厚みは製造条件のコントロールによ

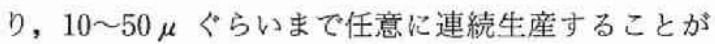
でき，製品の構成も従来品に比べ非常にバラエティに 富んでいる。

\section{2. 特長}

「スミライト ${ }^{\circledR}$ TFC $33 \mathrm{~A} 1$ および $13 \mathrm{~A} 1 」 の$ 特長は次 のようなものである.

1）而熱性が優れ，難燃性である。

2）誘電率, 誘電正接が小さく, 周波数依存性, 温度 依存性が少なく, 各種処理を施しても安定である.

3）表面，体積抵抗率が大きく，各種処理に対しても 安定である.

4）イオン性不純物が少なく，高信頼性である.

5）寸法変化率が小さく, 夕テ方向とヨコ方向がほぼ 同率である。

6）引き剝し強さの熱変化が小ざい.

7）ワイヤボンディングが容易である.

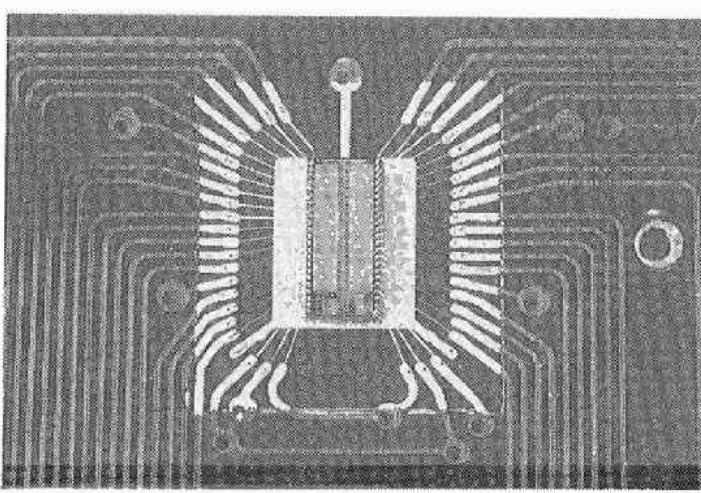

「スミライト® TFC 33A1 および 13A1 の写真」

\section{3. 用途}

以上のような特長をもつ「スミライト ${ }^{\circledR} \mathrm{TFC} 33 \mathrm{~A} 1$ および 13A1」の用途としては, 従来型のフレキシフ ルプリント配線板の代替のみならず, 従来各種の耐性 や信頼性の点でフレキシブル配線板が使用できなかっ た分野への応用が考えられる.また, 高純度, 低吸湿 という特徵から微細線回路での信頼性も高く, ワイヤ ボンティングも可能なことから, 高密度寒装基板とし ての使用にも威力を発揮するであるう。ささらに軽量性 ということからフロッピーディスク、ハードディスク ヘッドや, その他センサ, 航空宇宙関連機器の分野へ の応用も可能である.

\section{4. 今後の展開}

フレキシブルプリント配線板に対する要求はますま す多用化してきており，種々の使用形態に適用できる ように, 品種拡大や周辺技術の拡充を進めている.

\section{住友ベークライト（株）}

\section{フレキシブル回路事業部営業部} 本社

恶108 東京都港区三田 3-11-36 (三田日東ダイピル) ชా 03-457-8767 


\section{ネオフロン ${ }^{\circledR}$}

\section{熱溶融型フッ素樹脂}

ネオフロン®は, 射出成形や押出し成形が容易にで きる熱溶融型フッ素樹脂の総称です。

ネオフロン®は, PTFE の特性をそのまま維持 した PFA（テトラフルオロエチレンーパーフルオロフ ルキルビニルエーテル共重合体), FEP (テトラフル オロエチレンー八キサフルオロプロピレン共重合体) と分子中に $\mathrm{H} や \mathrm{Cl}$ を含み, 機械強度と溶融流動性に 優れた ETFE (テトラフルオロエチレンーエチレン共 重合体), PCTFE (ポリクロロトリフルオロエチレ ン), PVDF (ポリビニリデンフルオライド) の 5 品 種があります。

\section{1. 特徵}

ネオフロン®は, 表 1 に示すように品種によってそ れぞれ，優れた特徵があります.

ネオフロン PFA は, 最も耐熱性と成形性に優れ, PTFE にも匹敵する性能を有しており, FEP は若干 耐熱性が劣るものの, その他证 PFA に近い性質を持 っています. また ETFE は成形性, 機械強度, 耐薬 品性, 電気特性などバランスのとれた材料です

PCTFE は最も機械強度に優れた材料であり, 特 に,ガスバリヤー性や低温特性に優れています.

PVDF は, フッ素樹脂の中では最も低い温度で成 形でき, 機械強度と耐酸性に優れた汎用のフッ素樹脂 です。

\section{2. 用途}

ネオフロン®PFA, FEP, ETFE, PVDF は，耐熱性 と難燃性および電気特性に優れていることから電線被 覆材として多く使われていますが，このうち PFA は 不純物を含まず薬品などを污染しないこと, 耐薬品性 に優れていることから半導体装置の材料（ウェハーパ スケット、配管，エッチング槽なと゚）やライニング材 として最近注目されています.

主な用途について下記に示します.

PFA : 半導体関連器具, 耐食ライニング

FEP : 電線, 耐食ライニング, 離型フィルム

ETFE : 電線, 電気部品, 耐食ライニング

PCTFE : 防湿フィルム, 極低温バルブ

PVDF ：耐食ライニング, 耐候性塗料

\section{3. 将来の動向}

近年, 自動車・電気・電子・半導体分野の進歩は著 しいものがあります、今後さらに発展が期待される同 分野において, 小型化, 軽量化, 高信頼化が進む一 方，使用条件もますます苛酷なものとなり，今後いっ

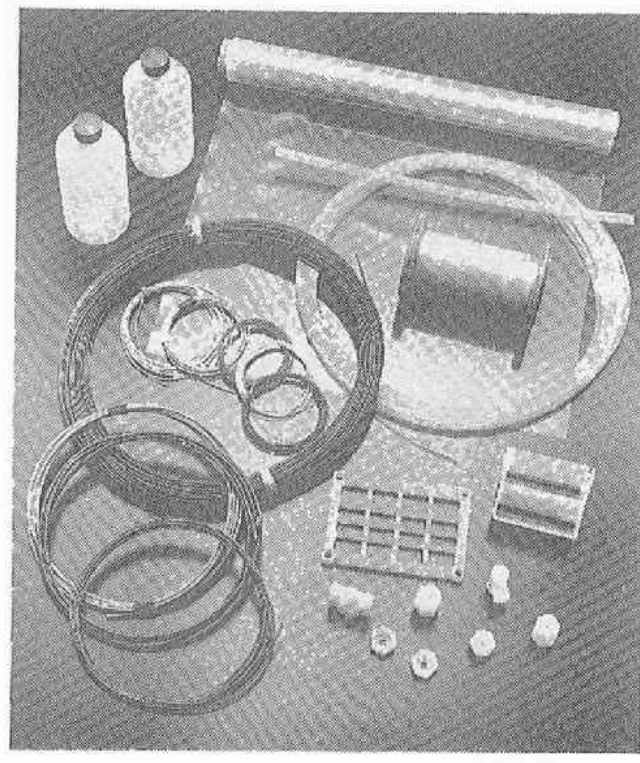

表 1 ネオフロン®の特性

\begin{tabular}{|c|c|c|c|c|c|c|c|c|}
\hline \multirow{2}{*}{ 特性 } & \multirow{2}{*}{$\begin{array}{l}\text { ポリ } \\
\text { フロン } \\
\text { PTFE }\end{array}$} & \multicolumn{5}{|c|}{ ネオフロン } & \multicolumn{2}{|c|}{ 沉用樹脂 } \\
\hline & & PFA & FEP & ETFE & PVDF & PCTFE & PP & PVC \\
\hline $\begin{array}{l}\text { 耐勢性 } \\
\left.\text { (裳用 }{ }^{\circ} \mathrm{C}\right)\end{array}$ & 260 & 260 & 200 & 150 & 150 & 130 & 100 & 60 \\
\hline $\begin{array}{l}\text { 機械的性放 } \\
\text { (䂺さ) }\end{array}$ & $\triangle$ & $\triangle$ & $\Delta$ & 0 & 0 & 0 & 0 & 0 \\
\hline 電気的性質 & (a) & (C) & (1) & (2) & 0 & 0 & (a) & $\triangle$ \\
\hline $\begin{array}{l}\text { 難燃性 } \\
(0.1 \%)\end{array}$ & 95 & 95 & 95 & 30 & 43 & 95 & 18 & 45 \\
\hline 耐薬品性 & (C) & (c) & () & (c) & $\Delta$ & 0 & $\Delta$ & $\Delta$ \\
\hline 耐候 性 & (2) & (C) & (0) & (2) & (C) & (c) & $x$ & $x$ \\
\hline スベリ性 & (a) & 0 & 0 & $\triangle$ & $\Delta$ & $\Delta$ & $\Delta$ & $\Delta$ \\
\hline 非粘着性 & (a) & (C) & (0) & 0 & $\Delta$ & $\triangle$ & 0 & $x$ \\
\hline 成 形 性 & $\triangle$ & (c) & (2) & (c) & (c) & 0 & (a) & (c) \\
\hline
\end{tabular}

$\mathrm{PP}:$ ポリプロピレン, PVC：硬質ポり塩化ビニル （）：非常に優れている，○：優れている, $\Delta$ : 使用可, $\times$ : 使用不可

そうフッ素樹脂の使用される分野が広がっていくもの と思われます。

\section{ダイキン工業 (株)}

化学事業部営業企画部

本社

３30 大阪市北区中崎西 2-4-12(梅田センターピル) 8ా 06-373-1201 (代表) 


\section{グラフトポリマー}

\section{1. 技術の背景}

東亜合成化学は，マクロモノマーの開発に続き，今 度，その技術を応用したグラフトポリマーGPシリー ズを開発した. グラフトポリマーGPは，マクロモノ マー法に基づいて合成されており，グラフト效率が高 く，分子構造の制御されたグラフトポリマーである.

近年, 樹脂成形分野においては, ニーズの多様化な どにより，沉用エンプラを中心としたポリマーアロイ やポリマーブレンドが盛んである。特にポリマーブレ ンドではその開発対象が相溶系から非相溶系に移りつ つあり, 適切な相溶化刘の開発が望まれている。グラ フトポリマー GP シリーズは，こうした要望に応える べく開発されたものであり，今後の発展が期待され る.

\section{2. 種類と構造}

グラフトポリマー GP シリーズの種類を表に示す その構造は, マクロモノマーが枝部分となる櫛型であ り, ポリマーブレンドの相溶性改良や樹脂の流動性改 良など, 少量添加により樹脂の物性改良を主たる目的 としたもの 5 グレード, 主に塗料やコーティング刘と して開発したもの 2 グレードがある。

\section{3. 効果と用途}

グラフトポリマーGP シリーズによれば，次のよう な効果と用途が期待できる。

1）相溶性の悪い樹脂同志のブレンドが可能.

2）樹脂の流動特性の改良.

3）印刷適性, 表面硬度など樹脂の表面物性の改良.

4）フィラー, 顔料など添加剤の分散性の改良.

5）症料，コーティング剤，接着郕に適用可能.

例えば,ナイロンの強鞋性，耐油性と ABS の耐衝 撃性, 成形性を利用したナイロン/ABS 系ポリマーブ レンドが検討されているが，この樹脂系は非相溶なた めブレンドすることができない.これにグラフトポリ マーGP-100を少量添加するだけで，ブレンドが可能 になる.同様に, 非相溶である PBT/PPO ポリマー ブレンドの相溶化剂として GP-500 があり, PBT の 特長である耐水性, 耐油性と PPO の特長である機械 的強度, 耐熱性を合わせ持ったブレンド樹脂とするこ とができる。

その他のポリマーブレンド、例えば PVC/ポリスチ レン系には GP-200, ナイロン/PPO 系にはGP-400, ポリオンフィン/ポリスチレン系にはGP-600の添加 が有奻である。
表 グラフトポリマーGP シリーズの種類

\begin{tabular}{|c|c|c|}
\hline グレード & 構造（幹／枝） & 主な用途 \\
\hline GP-100 & 変性アクリ $ル / \mathrm{PMMA}$ & 相溶化㧩 \\
\hline GP-200 & PS/PMMA & 流動性改良剈 \\
\hline GP-400 & 変性アクリル/PS & 表面改質浏 \\
\hline GP -500 & 変性アクリル/PS & 分散㓮 \\
\hline GP- 600 & 変性オンフィン/PS & 接着骫など \\
\hline GP-1000 & 変性アクリル/PMMA & コーティング剂 \\
\hline GP-2000 & 変性アクリル/PMMA & 㳂料など \\
\hline
\end{tabular}

また,グラフトポりマー GP-1000 (水系) や GP2000 (ラッカー系) を紙のコーティング剤に使用すれ ば, 柔軟性が有り, かつ, 表面の光沢・硬度の良好な 塗膜を得ることができる.

この他，グラフトポリマー GP シリーズとは別に, その姉妹品として，ナイロンに代表されるポリアミド 用反応性高分子潤滑剂：アロンルーブがある。これは ポリアミドと反応する官能基を持つシリコーン系グラ フトポリマーである.ポリアミドを成形, 織維, フィ ルムなどに加工する際, アロンルーブを少盡添加すれ ば，ポリアミドの欠点である潤滑性，吸水性，耐污染 性などが改善され, また, 従来のシリコーンオイル使 用に比へ，耐用年数を大幅に向上させることができ る.

\section{4. 将来の展望}

マクロモノマー法により開発されたグラフトポリマ 一 GP シリーズおよびアロンルーブは, 樹脂などの表 面や界面を改質し，新しい機能を付与させる効果が大 きいので, 今後, ますます既存材料の差別化剂, 機能 化偊として重要な位置を占めるであるう。

\section{東亜合成化学工業（株）}

研究企画室 機能材料開発グループ

西 105 東京都港区西新橋 1-14-1

80 03-597-7240 


\section{マクロモノマー}

\section{1. 技術の丠詈}

東亚合成化学は，長年培った機能性高分子合成技術 を基盤として，マクロモノマーを開発した。

近年の先端技術産業の発展に伴い, 高分子工業に扔 いては機能性高分子材料の開発が中心的課題になって いる．こうした時代の要請に対して，多成分系高分子 としてのグラフトポリマーが注目されている。これは ミクロ相分離構造に由来する多相構造をとり，効果的 に諸機能の発現が期待できることによる。

ポリマーの機能化から眺めた場合，例えば親水/踈 水，硬/軟などの相反する性簤を同時に満足させるこ とが重要な着眼点である。こうした相反する性賢を同 時に満足させる手段として，グラフトポリマーの利用 が有効であるが，従来のグラフトポリマーの合成方法 には制約が多く，汎用性の高いグラフトポリマーの合 成方法の開発が望まれていた。こうした要望に応える ベく開発されたのがマクロモノマーである。

\section{2. 特徵}

マクロモノマーとは，グラフトポリマー合成の前駆 物質として開発した末端に重合性官能基を有する简分 子量モノマーである. マクロモノマー法は，前もって 合成された枝成分（マクロモノマー）と幹成分モノマ 一を共重合させてグラフトポリマーとする，したがっ て, マクロモノマーで合成されたグラフトポりマー は，ホモポリマーの含有量が少なく，目的に合った分 子設計が可能になるという特徵がある。

\section{3. 構造と物性}

マクロモノマーの種類を表に示した。マクロモノマ 一のセグメントとして 5 種，末端重合性官能基として 3 種あり，付与したい機能によってマクロモノマーの セグメントを選び，共重合させるモノマーの種類によ り末端基を選ぶことができる。

\section{4. 機能と用途}

マクロモノマーで合成されたグラフトポリマーは, いくつかの特徵ある機能を持っている，幹部と枝部の 性質が大きく異なるグラフトポリマーは，両親媒性で ミセルを形成しやすい。この性質を利用し，分散重合 の分散剤として使用できる。

マクロモノマー法グラフトポリマーを直接窑料用ビ ヒクルに応用することも可能て，例えば AA-6 使用 により, 表面硬度と折り曲げ加工性の両立, 乾燥性の 向上など注目すべき物性改良効果が確認されている。

一方：シリコーン系マクロモノマーを使用したグラ
マクロモノマーの霾類

\begin{tabular}{l|c|c|c|c|c}
\hline \multirow{2}{*}{$\begin{array}{l}\text { 端基の } \\
\text { 種 }\end{array}$} & \multicolumn{5}{|c}{ マクロモノマーセグメントの種類 } \\
\cline { 2 - 6 } & St & St/AN & MMA & BA & シリコーン \\
\hline $\begin{array}{l}\text { メタクリ } \\
\text { ロイル基 }\end{array}$ & AS-6 & AN-6 & AA-6 & AB-6 & AK-5 \\
\hline $\begin{array}{l}\text { ジヒドロ } \\
\text { キシル基 }\end{array}$ & HS-6 & HN-6 & HA-6 & - & - \\
\hline $\begin{array}{l}\text { ジルルポ } \\
\text { キシル埾 }\end{array}$ & CS-6 & CN-6 & - & - & - \\
\hline
\end{tabular}

St：スチレン, AN：アクリロニトリル, MMA：メ チルメタクリレート、BA：ブチルアクリレート

フトポリマーは高酎候性塗料ビヒクルとして，また， 離型・潤滑特性を利用した用途へと展開可能である。

グラフトポリマーのミクロ相分離構造に基づく物理 架橋効果が，粘着剤の凝集力向上に役立つことが知ら れている。

さらに; 前記したグラフトポリマーの両親媒性を利 用して，非相溶性ポリマーブレンドの相溶化郕として 利用する試みがなされている。また，ポリマーアロイ への応用としては，マクロモノマーを反応押出成形に 利用する検討もなされている.

\section{5. 将来の展望}

マクロモノマーの応用範囲は，高分子材料全般にわ たり，機能性高分子の合成面の基本技術として，その 地歩を確立するであろう. 当面は, 塗料・コーティン グ材料・粘接着剂・樹脂成形材料分野での開発が進み, さらには医用分野や電子情報分野に打ける機能材料比 応用されよう。

\section{東亜合成化学工業（株）}

研究企画室 機能材料開発グループ

3105 東京都港区西新橋 1-14-1

× 03-597-7240 


\section{ソルダックス, ソルラック}

ポリパラバン酸樹脂 (PPA)

\section{1. 技術の背還}

電子部品は今やわれわれの生活と切離れないものに なっており，その進歩につれてますます高機能化，集 積化が進んでいる.これに伴い必要とされるのが䙳熱 性, 電気絶縁性の優れた素材であり, 各種のエンジニ アリング、プラスチックスの応用が検討されている。

東燃石油化学は，これらの要求に応えるものとして ポリパラバン酸樹脂 (PPA) フィルム「ソルダック ス』並びに PPA ワニス『ソルラック』を開発した。

このポリパラバン酸樹脂（PPA）は，エクソン社に よって開発されたジイソシアネートと青酸という㲸用 原料から合成されるュニークなポリマーで, 高温下で の電気特性に優れ，また種々の加工工程で要求される 耐熱性, 耐薬品性に十分応えられるガラス転移点が $290^{\circ} \mathrm{C}$ 以上の非晶性の高機能樹脂である。

ソルダックス・ソルラックは, これらの特性に加え てコスト的に有利な汎用原料を使用しており，䉓子部 品分野で今後の用途展開が期待される.

\section{2. 構造および物性}

ポリパラパン酸樹脂（PPA）はジイソシアネート （DI）と青酸とから合成される非晶性で本質的には熱 可塑性の樹脂である。

\section{-重合反応}

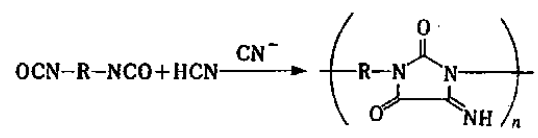

PIPA

- 加水分解

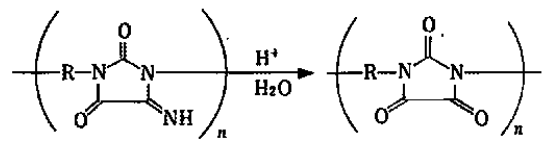

PPA

PPA の基本的な性質はこの五員環によるが，DI の 種類や組み合せ（共重合）により，いろいろな特性が 付与できる. DI としては下図のものが使われるが, コスト並びに実用特性の点で現状 MDI が中心であ る.<smiles>Cc1ccc(C)c(C)c1</smiles><smiles>Cc1ccc(Cc2ccc(C#N)cc2)cc1</smiles>

TODI $=$<smiles>Cc1ccc(-c2ccc(C)c(C)c2)cc1C</smiles>

EDI $=$

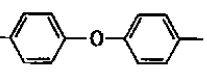

表 PPA の特性（25 $\mu$ フィルム）

\begin{tabular}{|c|c|c|c|}
\hline \multicolumn{2}{|c|}{ 項目 /グレード } & \multirow{2}{*}{$\frac{M}{1.36}$} & \multirow{2}{*}{$\frac{\mathrm{TM}}{1.36}$} \\
\hline 密度 & $\left(\mathrm{g} / \mathrm{cm}^{3}\right)$ & & \\
\hline 引彋破断強度 & $\left(\mathrm{kg} / \mathrm{mm}^{2}\right)$ & 11.5 & 18.0 \\
\hline 破断点伸び & $(\%)$ & 70 & 40 \\
\hline 引翏強度 & $(\mathrm{g} / \mathrm{mm})$ & 180 & 160 \\
\hline 色 相 & & 褐色选明 & 褐色透明 \\
\hline ガラス䎐移点 & $\left({ }^{\circ} \mathrm{C}\right)$ & 290 & 350 \\
\hline 熱膨张係数 & $@ 25^{\circ} \mathrm{C}\left(\mathrm{cm} / \mathrm{cm} /{ }^{\circ} \mathrm{C}\right)$ & $4.2 \times 10^{-5}$ & $3.0 \times 10^{-5}$ \\
\hline 熱伝酕率 & $50^{\circ} \mathrm{C}\left(\mathrm{kcal} / \mathrm{m} \cdot \mathrm{hr} \cdot{ }^{\circ} \mathrm{C}\right)$ & 0.27 & 0.27 \\
\hline 熱収繀率 @25 & (\%) & 0.30 & 0.20 \\
\hline ハンダ浴テスト & 15秒パス & 260 & 280 \\
\hline 長期使用荿熱温度 & $\left({ }^{\circ} \mathrm{C}\right)$ & 180 & 200 \\
\hline 吸湿率 & @ $25^{\circ} \mathrm{C}, 75 \% \mathrm{RH}(\%)$ & 1.6 & 1.6 \\
\hline 耐強アルカリ性 & & 劣 & 弱 \\
\hline 体稜抵抗率 & $(\Omega \cdot \mathrm{cm})$ & $5 \times 10^{16}$ & $5 \times 10^{16}$ \\
\hline 誘榓率 @1 $10^{8} \mathrm{~Hz}$ & $(-)$ & 3.4 & 3.4 \\
\hline 楅電正接@ $10^{3} \mathrm{~Hz}$ & $(-)$ & 0.0035 & 0.0035 \\
\hline 絶維破壊電圧 & $(\mathrm{KV} / \mathrm{mm})$ & 230 & 220 \\
\hline
\end{tabular}

表に代表的グレードのフィルムでの物性を示す。

3. 特性および用途

ソルダックス

ソルダックスは, PPA 溶液から流涩法により製膜 され, 高度な電気特性, 強度, 䨛熱性を要求される用 途に適す．特に耐熱フィルムとしてフレキシブルプリ ント回路 (FPC) 用途で必要とされる, リフロー型八 ンダ浴に酎える数少ないフィルムの一つである.

用途：FPC, TAB などの銅張耐熱絶緑基材および カパーレイ, 絶縁フィルム, ワイヤー/ケーブル被覆, 耐熱粘着テープ，スピーカー振動板.

ソルラック

ソルラックは, 重合の完結した PPA の溶液で, 溶 媒を蒸発させるだけでフィルムと同等の特性を有する 均一な可撓性の塗膜を形成し, 広い温度範囲で優れた 耐熱絶縁性, 耐薬品性を有す. 淡色にも着色可能. 密 着性，塗装性を改良した変性タイプも開発中.

用途：酎熱コート剂，酎熱塗料，耐熱エナメル線， 含漫ワニス, 酎熱接着剮.

\section{東燃石油化学 (株)}

本社 新製品事業本部 高機能樹脂開発グループ

(3) 104 東京都中央区築地 4-1-1

s. 03-542-7359 


\section{東レポリマーアロイ PPA シリーズ}

東レナイロン樹脂

\section{1. 技術の背景と市場動向}

ナイロン樹脂は, 剛性, 強勒性, 耐熱性, 成形性が 優れたエンプラであり, 自動車部品用途を中心にその 需要を拡大している. 最近では, ナイロン樹脂が有す る長所を保持しつつ, その欠点を補完するためにポリ マーアロイ技術が注目され，各種のナイロン系アロイ の検討が盛んに行われている.

東レが開発したポリマーアロイ “PPA” はナイロ ン,ポリフェニレンオキシドおよびゴム成分からな り, ユニークな構造と優れた特性を有する材料であ り, いろいろな用途展開が期待される.

\section{2. 構造と物性}

“PPA” は，結晶性のナイロンをマトリックス連続 相とし, 高 $T_{\mathrm{g}}$ 非晶性のポリフェニレンオキシドがー 次分散相を形成し,ささらに衝撃付与成分であるゴムが ポリフェニレンオキシド相中に二次分散するという独 特な相分離構造を呈している. 代表的物性を表に示 す.

\section{3. 特徵および用途}

“PPA" は次の特徴を有し, 写真に示すような自動 車のホイールキャップをはじめ, フェンダー・スポイ ラーなどの外板・外装部品, コネクターなどの自動車 のアンダーフード部品, 電気・電子部品, 一般機器の 構造部品などの用途に最適である.

（1）オンライン焼付塗装温度に耐える優れた耐熱性.

（2）低温でも脆性破壊しない高い耐衝撃性.

（3）剛性の温度による変化が小さく，耐クリープ性良 好.

（4）吸水性は小さく, 寸法安定性良好.

（5）ナイロンと同等の優れた耐薬品性, 耐油性.

（6）溶融流動性良好で，安定した成形性.

(7) 軽量.

\section{4. 将来動向}

材料に対する要求が，ますます高度化，複雑化する 中で, 東レのポリマーアロイは“PPA”をはじめとし て, 多様な展開が可能であり, 広範なマーケットへい っそうの貢献を目ざしている.

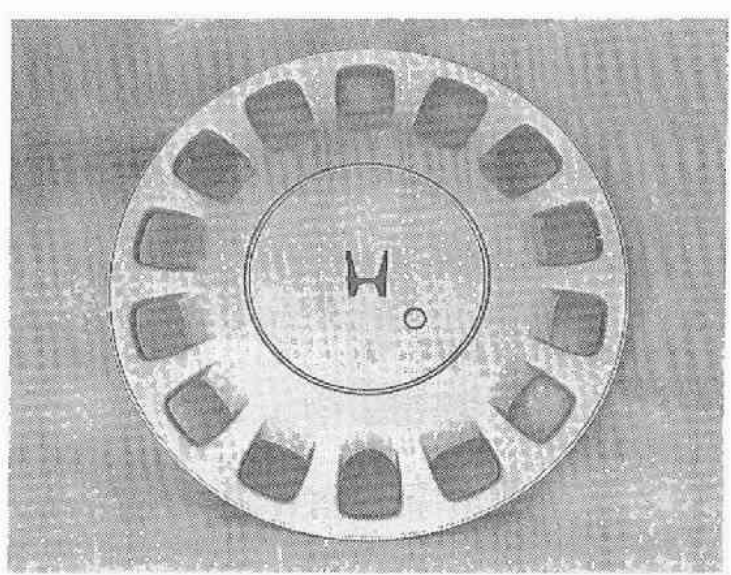

写真 "PPA" の用途例

表 東レポリマーアロイ “PPA” の代表的物性値

\begin{tabular}{|c|c|c|}
\hline 項＼cjkstart目（単位) & $\begin{array}{l}\text { PPA } \\
203\end{array}$ & $\begin{array}{l}\text { PPA } \\
263\end{array}$ \\
\hline 比 重 $(-)$ & 1.10 & 1.10 \\
\hline 引張強度 $\left(\mathrm{kgf} / \mathrm{cm}^{2}\right)$ & 590 & 560 \\
\hline 引張伸び(\%) & 60 & 80 \\
\hline 曲げ強度 $\left(\mathrm{kgf} / \mathrm{cm}^{2}\right)$ & 860 & 840 \\
\hline 曲げ弾性率 $\left(\mathrm{kgf} / \mathrm{cm}^{2}\right)$ & 21,000 & 21,000 \\
\hline $\begin{array}{l}\text { アイソ゚ット衝撃 } \\
\text { 強度 }(\mathrm{kgf} \cdot \mathrm{cm} / \mathrm{cm})\end{array}$ & & \\
\hline $1 / 2^{\prime \prime}$ ノッチ $23^{\circ} \mathrm{C}$ & 30 & 50 \\
\hline $1 / 2^{\prime \prime}$ ノッチ $\quad-20^{\circ} \mathrm{C}$ & 15 & 20 \\
\hline 熱変形温度 $\left({ }^{\circ} \mathrm{C}\right)$ & & \\
\hline $18.6 \mathrm{kgf} / \mathrm{cm}^{2}$ & 150 & 130 \\
\hline $4.6 \mathrm{kgf} / \mathrm{cm}^{2}$ & 190 & 190 \\
\hline 成形収縮率(\%) & $1.4 \sim 1.5$ & $1.0 \sim 1.1$ \\
\hline
\end{tabular}

\section{東レ（株）}

ナイロン樹脂事業部ナイロン樹脂販売課

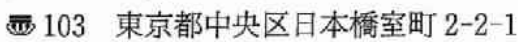

z 03-245-5497 5502

拜530 大阪市北区中之島 3-3-3

జ 06-445-3705 3709

《450 名古屋市中村区名駅 4-7-23

ชా 052-583-8231 


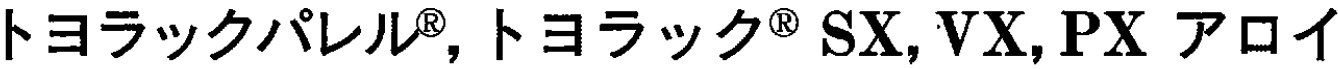

\section{東レ ABS}

\section{1. 技術の背豐と市場動向}

ABS は, 嶵性, 耐衝撃性, 耐熱性, 成形性, 価格 がバランスした樹脂であり, 自動車部品, 電気・電子 部品, OA機器, 一般機器, 雑貨などの用途を中心に その需要を拡大している，最近では，ABS の高機能 化，高性能化の手段としてポリマーアロイ技術が注目 され, 各種 ABS 系ポリマーアロイの検討が盛んに行 われている。

東レが独自のアロイ化技術を駆使して開発した（1) 永久制電性 ABS “トヨラックパレル”（2）高性能 $\mathrm{ABS}$ 系ポリマーアロイ“トヨラック” SX, VX, PX は，それぞれユニークな特徵を有する材料であり，い ろいろな用途展開が期待される。

\section{2. 構造と物性}

(1) “トヨラックパレル”

本材料は ABS 中に特殊な親水性ポリマーを独自の 相溶化手法を用いて微分散させたものであり，ABS の種類を変えることにより，標準，耐熱，難燃，ガラ ス瀻維強化，ポリカーボネートアロイなど多様なタイ プの永久制電性 ABS を設計することができる。透明 ABS と組合わせれば，原理的に透明タイプも可能で ある. “トヨラックパレル”標準タイプの一般物性を 表に示す。

(2) “トヨラック” SX, VX, PX アロイ

これらは ABS と汎用エンプラを組合わせた高性能 ポリマーアロイである．要求に応じてポリマーの種類 や配合組成を変えることができ，またガラス瀻維，あ るいはフィラー強化タイプ, 難燃タイプも設計可能で ある。それぞれの標準タイプの一般物性を表に示す。

\section{3. 特街および用途}

“トヨラックパレル”は ABS の優れた機械的特性, 表面外観，成形性を維持しながら，制電効果が半永久 的に持続される。成形品の表面固有抵抗は，布ふきや 水洗によって変化しない上に，帯電圧が小さく，帯電 圧の減衰が速いという特徵を有している．防麅や静電 気障害を防止したい用途に最適で，複写機・プリンタ ー・ファクシミリなどの OA 機器のハウジングや内部 部品, 電気・電子部品などのハンドリング用コンテナ, 光・磁気メディアの基板・収納ケースなどに展開でき る。

“トヨラック” SX, VX, PX は, 極めて高い衝擊強 度を有し, 耐熱性, 耐薬品性, 耐摩耗性, 成形性など が良好で，自動車の外装・内装・アンダーフード部品，
表 “トヨラックパレル”および “トヨラック” SX, VX, PX の物性

\begin{tabular}{l|r|r|r|r}
\multicolumn{1}{c|}{ 項 目 (単位) } & $\begin{array}{r}\text { パレル } \\
\text { TP 10 }\end{array}$ & SX.01 & VX 10 & PX \\
\hline 比重(一) & 1.05 & 1.07 & 1.16 & 1.10 \\
引張強度 \\
$\left(\mathrm{kgf} / \mathrm{cm}^{2}\right)$
\end{tabular}

䉓気・電子部品, 一般機器・OA 機器のハウジング 内部部品, スポーツ用品・玩具などの用途に最適であ る.

\section{4. 将来動向}

材料に対する要求が，ますます高度化，複雑化する 中で, 東レのポリマーアロイは多様な展開が可能であ り,マーケットへのいっそうの貢献をめざしている.

\section{東レ（株）}

トヨラック事業部トヨラック販売課

@103 東京都中央区日本橋室町 2-2-1 東レビル ح 03-245-5506 (值)

(330 大阪市北区中＼cjkstart島 3-3-3（三井ビル）

206-445-3715 (直)

４50 名古屋市中村区名駅 4-7-23 （豊田ビル 5 F） 2052-583-8231 (直) 


\section{トレリナ ${ }^{\circledR}$}

\section{PPS 樹脂}

\section{1. 技術の背㟟}

ポリフェニレンサルファイド (PPS) は 1973 年米国 フィリップス社により初めて上市された耐熱性, 酎薬 品性に優れた熱可塑性樹脂であり, 日本でもその需要 は着実に増加し，1987 年には，約 $4000 \mathrm{t} /$ 年となって いる。東レはフィリップス社との合弁会社である東 レ・フィリップスペトローリアム社から PPS 原末の 供給を受け，独自のコンパウンド技術を付加して，強 化材，充填材，潤滑材などと複合化した特長のある各 種グレードを製造・販売している.

\section{2. 特徵および用途}

\section{〈構造と特徴〉}

PPS の基本化学構造は下式で示され, 耐熱性, 耐 薬品性の他に難燃性（PPS 樹脂自体 UL94V-0 に合 格), 寸法安定性, 而疲労性, 耐クリープ性, 絶縁性 などにも優れている。

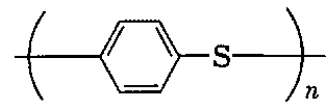

“トレリナ”にはベースポリマーとしてキ_アリン グ処理により部分架橋構造を有し，特に耐熱性の優れ た架橋型ポリマーと，高分子量で強鞄性に優れた直鎖 型ポリマーとがあり，各々の特長を生かした品質設計 がなされている.

表に“トレリナ”の代表的な射出成形グレードの物 性を示す. A504 は架橋型ポリマーをべースとしたガ ラス絨維強化グレードであり, 高温強度や流動性に優 れている. A310MX04はガラス織維と無機充墴材を 複合化して用い，特に高い寸法安定性を実現したもの である.一方, A604 は直鎖型ポリマーをガラス織維 で補強して扔り，直鎖型ポリマーの高い強靯性を反映 して, 高い強度と耐衝繁性を有している，A674M2 はさらにユニークなポリマーアロイ化技術を組み合わ せて著しく高い衝撃強度を達成したものである。

\section{〈用途〉}

“トレリナ”は，上記のように優れた特性を有して いることから，次のような用途に適している.

（1）䉓気・電子分野：コネクタ，コイルボビンなどの 電子部品, 電子レンジ用トレイなどの家電部品お よび IC やトランジスタなどの封止材.

（2）自動車分野：各種スイッチなどの電装部品, ウォ ーターポンプインペラなどのエンジン部品わよび ランプリフレクタなどの機構部品.
表 “トレリナ”射出成形グレードの物性

\begin{tabular}{|c|c|c|c|c|}
\hline 項 目 (単位) & A 504 & $\begin{array}{l}\text { A 310 } \\
\text { MX 04 }\end{array}$ & A 604 & $\begin{array}{c}\text { A 674 } \\
\text { M2 }\end{array}$ \\
\hline ベースポリマ(一) & 架檢型 & 架㛢型 & 直銷型 & 直鎖型 \\
\hline 補強材 (一) & GF & Gl & GF & GF \\
\hline 比 重 $(-)$ & 1.70 & 1.96 & 1.67 & 1.56 \\
\hline 引張強度 $\left(\mathrm{kg} / \mathrm{cm}^{2}\right)$ & 1,600 & 1,450 & 1,750 & 1,500 \\
\hline 曲げ強度 $\left(\mathrm{kg} / \mathrm{cm}^{2}\right)$ & 2,100 & 2,050 & 2,400 & 2,000 \\
\hline 曲げ弾性率 $\left(\mathrm{kg} / \mathrm{cm}^{2}\right)$ & 140,000 & 180,000 & 130,000 & 95,000 \\
\hline 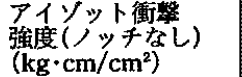 & 30 & 20 & 45 & 60 \\
\hline $\begin{array}{l}\text { 熱変形温度 } \\
\left(18.6 \mathrm{~kg} / \mathrm{cm}^{2}\right)\left({ }^{\circ} \mathrm{C}\right)\end{array}$ & $260<$ & $260<$ & $260<$ & 255 \\
\hline 燃狫性(U & 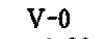 & $\mathrm{V}-\mathrm{C}$ & $\mathrm{V}-0$ & $\mathrm{~V}-1$ \\
\hline 成形收縮率 & 0.2 & 0.1 & 0.20 & \\
\hline $\begin{array}{l}\left(1 / 8^{\prime \prime} \mathrm{t}\right) \\
\left(\mathrm{kg} / \mathrm{cm}^{2}-\mathrm{G}\right)\end{array}$ & 26 & 38 & 32 & 33 \\
\hline
\end{tabular}

（3）一般機械分野：時計シャーシ，OA 機器部品など の精密部品および機械部品.

3. 将来の動向

PPS 樹脂は今後も約 $20 \% /$ 年の高率で成長し, 1992 年には名実ともに第 6 のエンジニアリングプラ スチックとして 1 万t/年の需要量に達するものと期 待されている, 東レは架橋型, 直鑟型の両ポリマを持 つ強みを生かして，ますます多様化するニーズに適合 した新製品の開発に注力している.

\section{東レ（株）}

機能樹脂事業部

機能樹脂販売第 2 課

e103 東京都中央区日本橋室町 2-2-1

8 03-245-5511 5513 FAX 03-245-5515

大阪機能樹脂販党第 2 橦

(530 大阪市北区中之島 3-3-3

806-445-3710 3711 FAX 06-445-3731

名古屋機能樹脂販売課

450 名古屋市中村区名駅 4-7-23

zా 052-583-8234 FAX 052-583-8216 


\section{東レ PBT 樹脂}

\section{ポリエステル樹脂}

\section{1. 技術の背罝と市場動向}

ポリブチレンテレフタレート (PBT) は, テレフタ

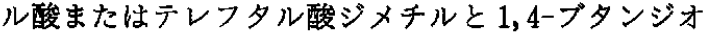
ールを重縮合させることによって得られる熱可塑性ポ リエステルの一種である，PBT は物理的・化学的性 筫，機械的性質，電気的性質などに優れているのに加 えて結晶化速度が速いことから，射出成形材料として 䉓気・電子機器部品, 自動車部品などの用途を中心に その需要を拡大しており，今や代表的なエンジニアリ ングプラスチック(エンプラ)の地位を確保している.

PBT は前記のように優れた特徵を有する反面， ッチ付衝撃強度や酎加水分解性が低いとの指摘もあ ク，これらの特性に対する要求が籗しい用途では，そ の使用が制限されていた，前者の衝撃強度改良につい ては種々の改良研究が行われ，東レの耐衝撃性改良グ レードである 5201 や $5101 \mathrm{G}$ シリースに代表される各 種の改良グレードが上市され，その用途拡大に寄与し ている. 一方, 雨加水分解性の改良に関しては依然と してPBTに抢ける大きな課題であった。

東レが罗近，新しいポリマー変性技術によって開発 した $5108 \mathrm{G}$ シリーズは，この耐加水分解性を大幅に 改良した画期的なグレードであり，従来 PBT の使用 が困難であった種々の用途に対して展開が期待され る.

2. 構造と物性

PBT の化学構造は下式で表わされる.<smiles>CCC(C)(C)OCCCCOC(=O)c1ccc(C(=O)C2(C)CCCC2)cc1</smiles>

5108G シリーズの物性を，一般のガラス絨維強化 PBT および耐衝撃性改良グレードと比較して表に示 す.

\section{3. 特徵および用途}

5108G シリーズは，PBT の一般的特徴である成形 性, 耐溶剤性, 耐熱性, 電気的性質, 機械強度などに 加え，次のような特街を有している.

(1) 耐加水分解性に優れている.

(2) 耐衝擊性が高い.

(3) 耐ヒートサイクル性に優れている。

(4) 耐乾熱劣化性および溶融滞留安定性が良好であ る.

前記のような特徵から, 電気・電子部品, 自動車部
東レ PBT 樹脂雱加水分解性改良グレードの物性

\begin{tabular}{|c|c|c|c|}
\hline 項 目 (単位) & $\begin{array}{r}5108 \text { G-15 } \\
\text { (醉㖥水分解性) }\end{array}$ & $\begin{array}{c}5101 \mathrm{G}-15 \\
\text { (高衡撃) }\end{array}$ & $\begin{array}{c}1201 \mathrm{G}-15 \\
\text { (標 準) }\end{array}$ \\
\hline 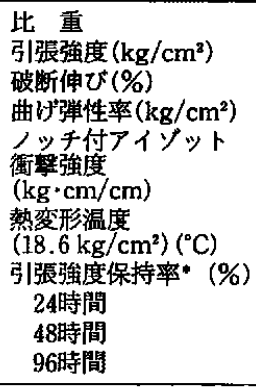 & $\begin{array}{r}1.36 \\
800 \\
7.5 \\
42,000 \\
\\
12.5 \\
\\
200\end{array}$ & $\begin{array}{r}1.36 \\
900 \\
5 \\
48,000 \\
\\
13.5 \\
\\
204\end{array}$ & $\begin{array}{r}1.42 \\
1,000 \\
5 \\
51,000 \\
\\
5.5 \\
\\
206\end{array}$ \\
\hline
\end{tabular}

* $120^{\circ}$ Cスチーム下放置

品，機械部品などに幅広く使用できる．特に耐加水分 解性の要求の厳しい自動車のアンダーフード部品など に対して今後，種々適用されるものと考えられる。

\section{4. 将来動向}

PBT 樹脂に対する要求は現在，ますます高度化・多 様化しており，従来の一般的な PBT では対応しきれ ない用途が多数出現している．東レはこのような種々 の要求に応えるべく, 前記以外にも各種のポリマーア 口イ技術，複合化技術，ポリマー変性技術などさまざ まな改良研究を行っており, 今後の PBT の新用途展 開に対していっそう貢献できるものと確信している。

\section{東レ(株)}

機能樹脂事業部

機能樹脂販売第 1 課

3. 103 東京都中央区日本橋室町 2-2-1

Z 03-245-5510 5511 FAX 03-245-5515

大阪機能樹脂販売第 1 課

530 大阪市北区中之島 3-3-3

206-445-3706, 3709 FAX 06-445-3731

名古屋機能樹脂販売課

巴50 名古屋市中村区名駅 4-7-23

z 052-583-8234 FAX 052-583-8216 


\section{モディパー A4000 シリーズ}

ポリオレフィン系グラフトポリマー

\section{1. 技術の背暴と市場勳向}

近年, プラスチックス材料の高機能化，多機能化が 市場の強い要請となっており，その一手段として異種 のポリマーを組合せたポリマーアロイが注目されてい ます.また，ポりマーアロイを開発するためには，相 溶化剤が必須であることが知られています。

日本油脂では，このような市場のニーズに対応すべ く,ブロックポリマーなどの機能性ポリマーを開発し てまいりましたが, このたび, 当社のグラフトポリマ 一製造技術を結集して，ポリオレフィン系グラフトポ リマーであるモディパーA4000 シリーズを開発いた しました。

\section{2. 構造と物性}

モディパー A4000 シリーズは, 主鎖のポリオレフ インが反応性を有する EGMA（エチレン・メタクリル 酸グリシジル，側鎖がビニルポリマーから成ってい るため, 縮合系エンジニアリングプラスチックスなど の官能基を有する他ポリマーと反応させることも可能 な極めて特徴のあるグラフトポリマーであります。

\section{3. 特徵と用途}

モディパー A4000 シリーズは，グリシジル基とい う官能基を有するグラフトタイプ高分子界面活性剂と いうことができますしたがって，用途としては，グ ラフトポリマーの特徵である他樹脂への分散性, ある いは分散性と反応性を利用した用途が考えられ，主に エンジニアリングプラスチックスの耐衝慗性改良刘, または, ポリマーアロイ用の相溶化剂, 接着性改良 剤，無機物分散助刘などへの応用が考えられます。

\section{4. 将来の動向}

現在, 当社では EGMA 以外の各種オレフィンを幹 としたグラフトポリマーを開発中であり, 近い将来に は皆様に提供することができます。
表 1 モディパーA 4000 シリーズの種類

\begin{tabular}{|c|c|c|}
\hline 品 名 & 構 & 重量比 \\
\hline A 4100 & EGMA-g-PS & $70 / 30$ \\
\hline A 4200 & EGMA- $\mathrm{g}-\mathrm{PMMA}$ & $70 / 30$ \\
\hline A 4400 & EGMA-g-AS*) & $70 / 30$ \\
\hline
\end{tabular}

*) AS 中のアクリロニトリル含有量は 30 重量\%

表 2 モディパーA 4000 シリーズの物性

\begin{tabular}{|c|c|c|c|c|}
\hline 項 目(単位) & 鶕験法 & A 4100 & A 4200 & A 4400 \\
\hline $\begin{array}{l}\text { メルトインデッ } \\
\text { クス }(\mathrm{g} / 10 \mathrm{~min})\end{array}$ & JIS K 7210 & 0.7 & 0.6 & 0.3 \\
\hline 密 度 $\left(\mathrm{g} / \mathrm{cm}^{3}\right)$ & JIS K 7112 & 0.977 & 0.993 & 0.977 \\
\hline $\begin{array}{l}\text { 引張最大強さ } \\
\left(\mathrm{kgf} / \mathrm{cm}^{2}\right)\end{array}$ & JSI K 7113 & 160 & 143 & 160 \\
\hline 破断点伸び (\%) & JIS K 7113 & 72 & 100 & 71 \\
\hline $\begin{array}{l}\text { 引張弾性率 } \\
\left(\mathrm{kgf} / \mathrm{cm}^{2}\right)\end{array}$ & JIS K 7113 & 1,440 & 862 & 1,360 \\
\hline $\begin{array}{l}\text { アイソット衝嶅 } \\
\text { 強度 }(\mathrm{kgf} \cdot \mathrm{cm} / \mathrm{cm})\end{array}$ & JIS $\mathrm{K} 7110$ & 破断せず & 破断せず & 破断せず \\
\hline $\begin{array}{l}\text { ビカット軟化温 } \\
\text { 度 }\left({ }^{\circ} \mathrm{C}\right)\end{array}$ & JIS K 7206 & 83 & 80 & 87 \\
\hline $\begin{array}{l}\text { 荷重たわみ温度 } \\
\left({ }^{\circ} \mathrm{C}\right)\end{array}$ & JIS K 7207 & 53 & 50 & 57 \\
\hline 硬度 (ショアD) & JIS K 7215 & 55 & 51 & 56 \\
\hline
\end{tabular}

*) 試験速度 : $50 \mathrm{~mm} / \mathrm{min}$ (上記数值は代表値であり 規格値ではありません。)

\section{日本油脂（株）}

化薬事業部化成品営業部開発グループ

业100東京都千代田区有楽町 1-10-1

o5 03-283-7242 


\section{ノバキュレート}

\section{液晶ポリマー}

ノバキュレート（NOVACCURATE）は，当社が独 自に開発した芳香族ポリエステル系のサーモトロピッ ク液晶ポリマーで, 次のような特長を有しています

非常にコストパフォーマンスの優れた新しいエンジ ニアリングプラスチックです。

特長

- 高剛性, 高強度

きわめて高弾性率の成形品が得られます 成形品 はまた高い強度を有しています。

・優れた寸法精度

線膨張係数がきわめて小さく（金庽アルミニウム 並み)，また，成形収縮率も非常に小さくかつ， 良好な寸法安定性を有することから寸法精度の要 求の高い成形品に適しています。

\section{-高溶融流動性}

溶融流動性が非常に良好なことから成形がきわめ て容易となり，極薄肉や複雑な形状物の成形が可 能となります。

・さらに

耐薬品性, 振動減臺特性, 低吸水性などに非常に 優れています
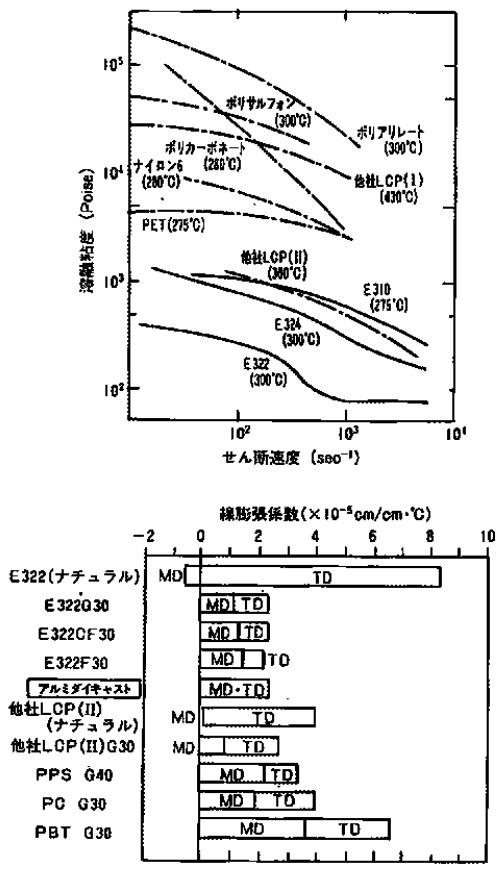

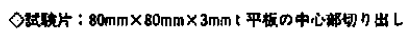
$\diamond ケ ゚-ト: 1.5 \mathrm{~mm}$ フイルム

方向: NO: 流野方向, TD:直䏍方向

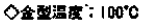

代表的グレード

\begin{tabular}{|c|c|c|c|}
\hline グレード & 程 類 & 特 & 㖕適成形 \\
\hline E 322 G 30 & $\begin{array}{l}\text { ガラス絩維 } \\
\text { (GF) 光城 }\end{array}$ & 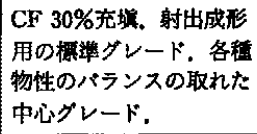 & 射出成形 \\
\hline E 322 CF 30 & $\begin{array}{l}\text { カーボン㼄維 } \\
\text { (CF)充埧 }\end{array}$ & $\begin{array}{l}\text { CF 30\%充顷，射出成形 } \\
\text { 用の高滆性ダレード. }\end{array}$ & 射出成形 \\
\hline E. 322 F 30 & $\begin{array}{l}\text { 無機フィラー } \\
\text { (F)充填 }\end{array}$ & $\begin{array}{l}\text { F 30\%充坫. 射出成形用 } \\
\text { の改賞 (表面性他) グレー } \\
\text { ド }\end{array}$ & 射出成形 \\
\hline
\end{tabular}

○上記の他; 各種特殊フィラー充城グレードや群燃グレード (UL $94 \mathrm{~V} \cdot 0 \cdots 1 / 32^{\prime \prime}$ ) 瀷動性改良ダレード, さらに, 稿々用 途仁合わせたカスタマーグレードも開発しております。

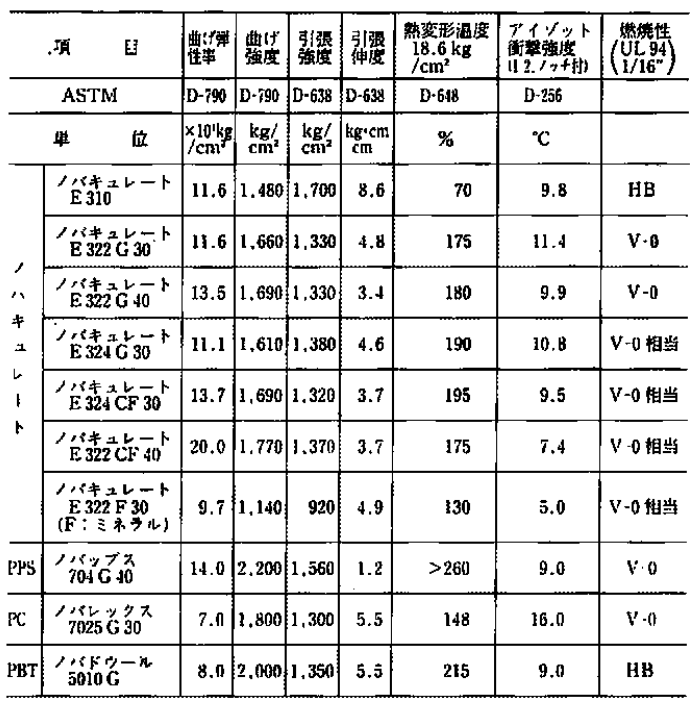

\section{三菱化成（株）}

\section{機能樹脂事業部}

本社

⑩0 東京都千代田区丸の内 2-5-2

(三菱ビルディング)

203-283-6782 - 6722 FAX 03-286-0090 


\section{ユーピロン $\mathrm{AL} \cdot \mathrm{FR}$, ユーピロン $\mathrm{Z}$}

機能性ポリカーボネートオリゴマー, 高アモルファスポリカーポネート

『ユーピロン AL』と『ユーピロンFR』はポリカー ボネートの技術から生まれた樹脂改質材である。

\section{1.「ユーピロン $\mathrm{AL}$ の特性}

「ユーピロン AL】はビスフュノール A ポリカーポ ネートのオリゴマーで，樹脂の耐熱性を損なうことな く成形加工性を改良する。

この改質材は通常の可塑剤のような金型污染がな W.

また粉本状で，ポリスキレン，ABS，アクリル， ポリエステル, ポリスルホン, PPS などに添加して 押出加工時にコンパウンド化できる。

例えぱ ABS 樹脂に『ユーピロン AL】を添加する と, 図のように耐熱性を損なうことなく流動性を改良 できる。

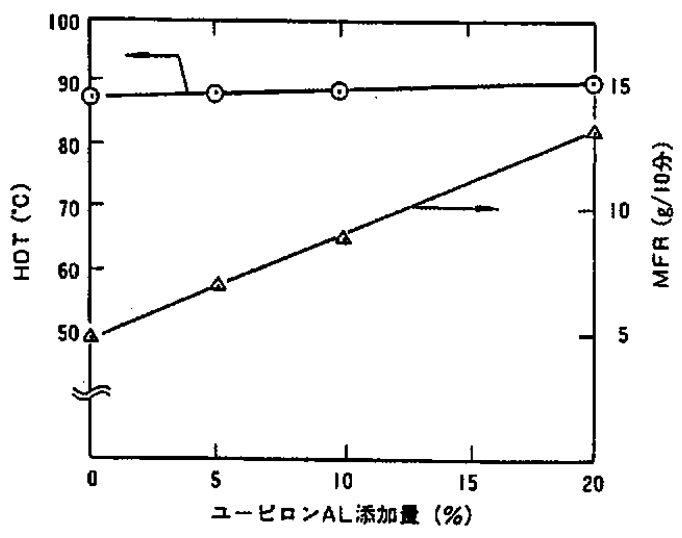

\section{2.「ユーピロン FR」の特性}

『ューピロンFR』は揮発性がほとんどない目熱性 の難燃剤である、テトラブロムビスフェノール A を 主原料にしたポリカーボネートオリゴマーから成る。

「ューピロンFR」には, ホモタイプ (FR-30) とコ オリゴマータイプ (FR-34) の 2 種類を用意している. 前者はフェノール性水酸基を有する反応タイプ, 後 者は非反応性の耐熟性タイプである。

\begin{tabular}{|c|c|c|c|c|}
\hline \multirow{2}{*}{ 性 } & \multirow{2}{*}{ 零 } & \multirow{2}{*}{$\underset{\mathrm{AL}}{\text { ユーピロン }}$} & \multicolumn{2}{|c|}{ ユーピロン FR } \\
\hline & & & FR-30 & FR-34 \\
\hline 外 & & 白色粉末 & 白色粉末 & 白色粉末 \\
\hline 平均重合度 & & 7 & 3 & 3 \\
\hline 溶 融 点 & ${ }^{\circ} \mathrm{C}$ & 210 & 170 & 170 \\
\hline 鼻萦含有率 & $\%$ & 0 & 57 & 55 \\
\hline
\end{tabular}

『ユーピロンZ】は下記のような棈造を持った高ア モルファスポリカーボネート樹脂である.

通常のビスフェノール A 型ポリカーボネートに比 べ結晶性がほとんどなく溶媒からキャストフィルムを 製造する用途に最適である。このため, 複写機用有機 光電詥体 (OPC) の電荷移動剂のバインダーや，オプ トエレクトロニクス用の基枋，例えば有機光導波路材 料として用いられている。<smiles>CC(C)(C)OC(=O)Oc1ccc(C2(c3ccc(OC(C)(C)C)cc3)CCCCC2)cc1</smiles>

1.「ユーピロンZ』の性票

- 外観

- 溶融点

白色粉末またはフレーク

- 粘度平均分子圐 $250^{\circ} \mathrm{C}$

2. ユーピロン Z の特性

（1）結晶化が起こらず得られたキャスティングフィ ルの透明度が高い.

（2）溶媒の種類に限らず溶液状態の保存安定性に優 れている。

（3）溶媒の選択楅が広い，例えばビスフェノール A 型ポリカーボネートの筫溶媒であるべンぜ ンやトルエンにも溶解する。

（4）得られたフィルムは, 硬度が高く丽摩耗性に優 れている.

（5）曲げ疲学特性に優れている.

\section{三菱瓦斯化学 (株) \\ 合成樹脂開発部 \\ ® 100 東京都千代田区丸の内 2-5-2（三菱ビル） \\ 8 03-283-4853 FAX 03-287-2642}




\section{ユーピロン/ユピタール/ユピエース/レニー}

\section{ポリマーアロイ}

\section{1. 開発の背景}

エンジニアリングプラスチックは, 優れた性能と使 いやすさなどによって産業界に浸透してきた.

しかし, 最近ではニーズの多様化と高度化によって 個々のエンプラでは対応できない場合も多く, アロイ 化による材料開発が脚光をあびるところとなった.

\section{2. 三菱瓦斯化学(株) のポリマーアロイ}

エンプラ 4 種を有する総合エンプラメーカー三菱瓦 斯化学 (株) は, 高度化する市場ニーズに応えるため, ポリマーアロイの各種開発に取り組んできた.

ここでは, ポリカーボネート (PC)『ユーピロン』, ポリアセタール (POM)『ユピタール】, ポリフェニレ ンエーテル (PPE)『ニピエース』, およびポリアミド (PAMXD 6)『レニー』をべースとするポリマーアロ イグレードを紹介する.

3. ポリカーボネートのアロイ

抜群の衝擊強度を有する PC『ユーピロン』は, 機 械的性質や耐熱性などの諸特性に優れた透明非晶性樹 脂であるが, 唯一つ, 耐ストレスクラック性に難点が あり，その応用範囲をせばめていた。

『ユーピロン MB2100』や『ユーピロン MB4300』 は, その改良を目的に設計されたアロイである, 各シ リーズの特長は以下のと初り。

『ユーピロン MB2100』: PC/PET 系

（改質）耐薬品・耐油性, 低温衝撃強度の改良

(用途) 自動車ドアハンドル，ビデオカメラスイッ チ,メーターハウジングなど

『ユーピロン MB2200 (GP)」: PC/ABS 系

(改質) 高流動化, ABS の強度, 而熱性向上

(用途) カメラ部品, 自動車のクラスター, インパ ネ類, ハウジングやシャーシー類

『ユーピロン MB3500」：PC/コポリエステル系

(改質) 耐 $\gamma$ 線照射性の改良, 透明性保持

(用途) ダイヤライザー, 人工心肺などの医療機器

『ユーピロン MB4000」: PC/PBT 系

（改質）耐薬品・耐油性, 低温衝撃強度の改良

（用途）ドアハンドル，バンパーなどの自動車部品

3. ポリフェニレンエーテルとポリアミドのアロイ

高い耐熱性と優れた機械的性質を有する非晶性の 『ユピエース』と優れた耐油性と成形性を有する結晶 性のポリアミドとを独自手法によりアロイ化した.

自動車の塗装ラインに使用できる抜群の耐熱強度と 低温衝撃強度を特長とするシリーズである.

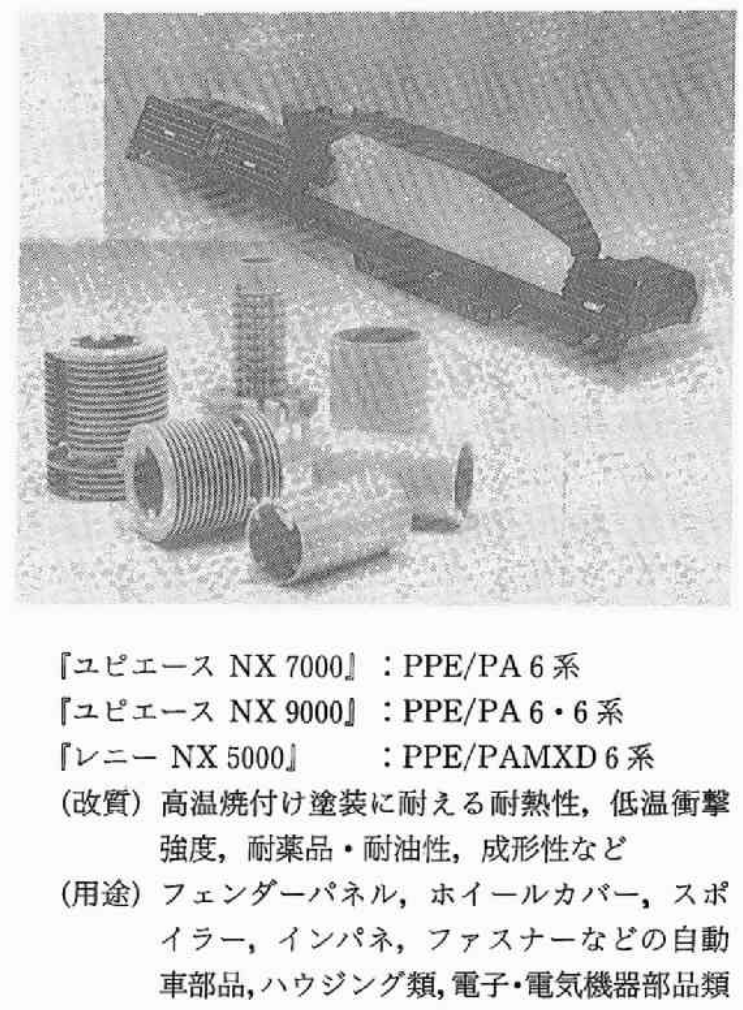

4. ポリアセタールのアロイ

耐摩擦・摩耗性, 耐疲労性, 耐油性などに優れた 『ユピタール」のアロイグレードである.

『ユピタール FU」: POM/ポリウレタン系

(改質) 衝撃強度, 軟質化

(用途) 軟質·無騒音歯車類, クリップ類, 自転車変 速切替ハンドルなど

当社は今後もューザー, モルダー各位と共に新しい 材料の開発を通じて社会に貢献するつもりである.

\section{三菱瓦斯化学（株）}

合成樹脂開発部

(3100 東京都千代田区丸の内 2-5-2 (三菱ビル)

z 03-283-4850 


\section{CFI プロセス}

\section{表面高機能化成形プロセス}

\section{1. 技術の背景とプロセス}

成形と同時に表面を高機能化できないだろうか？ この着想を三菱瓦斯化学は次の 3 つの技術を着実に研 究開発することで完成させた。

(1) ポリカーボネート樹脂『ユーピロン』のフィルム 製造およぴューピロンの射出成形技術

（2）ユーピロン・フィルムの高機能化技術（ハードコ ート. 防夢コートなど)

(3) ユーピロン・フィルムの金型へのインサート技術 「CFIプロセス』は高機能化ユーピロン・フィルムを 製品形状に合わせて打ち抜いたあと,これを金型に装 着して, 射出成形と同時に表面高機能化を行うという 斬新なものである. したがって工程の短縮と品質向上 を同時に可能とし，コストの削減にも貢献できる.

\section{2. 特長および用途}

『CFI プロセス』の特長を経済性, 物性, デザイン 性の 3 点から説明すると次のようになる.

(1) 抜群の経済性

(1) 従来工法にくらべて工程が大幅に短縮される.

(2) 不良率, 加工費の低減をもたらす.

(3) 安価な樹脂をコア材に使用でき，材料コストが 節約できる。

(4) 金型の鏡面仕上け゚を大幅に下げることができる.

（2）卓越した物性

(1) ハードコート処理による衝撃強度の低下がない.

(2) 脆いコア材を使用しても衝撃強度の優れた製品 を得ることができる.

(3) 超耐候性, 而摩耗性, 耐薬品性, 而熱性に優れ た製品を得ることか゚できる.

（3）デザイン性

(1) フローマーク. ウェルドラインの心配がない.

(2) 成形品端部も液だれがなく美しく仕上がる.

(3) レンズカット, 魚眼カット形状へも容易にマー ク・文字を入れることが可能.

用途としては, 自動車分野のグレージング, 内外装 部品・ OA 機器, 家庭電化製品, 建材分野のグレージ ングなどがあり, 特にデザイン性が高く, 高品質なも のを要求される部位に期待されている.

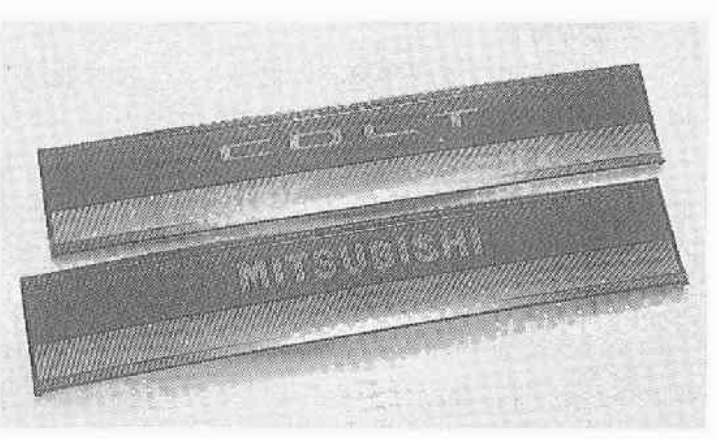

3. ハードコート成形品の物性例

\begin{tabular}{|c|c|c|}
\hline 性 & 単 & 測定値 \\
\hline 比 & & 1.2 \\
\hline 届 折 率 & & 1.59 \\
\hline 全光線透過率 & $\%$ & 93.6 \\
\hline 値 & $\%$ & 0.1 \\
\hline 引 張 強 さ & $\mathrm{kg} / \mathrm{cm}^{2}$ & 650 \\
\hline 引 張 伸 び & $\%$ & 120 \\
\hline 曲げ強さ & $\mathrm{kg} / \mathrm{cm}^{2}$ & 850 \\
\hline 曲 げ 弾 性 率 & $\times 10^{4} \mathrm{~kg} / \mathrm{cm}^{2}$ & 2.35 \\
\hline アイソ゚ット衝撃(ノッチ付き) & $\mathrm{kg} \mathrm{cm} / \mathrm{cm}$ & 85 \\
\hline $\begin{array}{l}\text { テーパー摩耗 } \\
500 \mathrm{~g} .100 \text { cycles }\end{array}$ & $\triangle \mathrm{H} \%$ & 2.0 \\
\hline 落砂試験 $\quad \# 80 \mathrm{Sic}, 1000 \mathrm{~g}$ & $\triangle \mathrm{H} \%$ & 4.6 \\
\hline$\# 80 \mathrm{Sic}, 1600 \mathrm{~g}$ & $\triangle H \%$ & 7.2 \\
\hline $\begin{array}{r}\text { スチールウールテスト } \\
1000 \mathrm{~g} 15 \text { press }\end{array}$ & $\triangle \mathrm{H} \%$ & 0.4 \\
\hline 鉛 筆 硬 度 & & $\mathrm{HB}$ \\
\hline 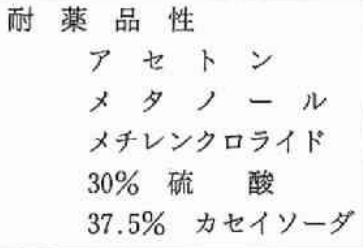 & & $\begin{array}{l}\text { 外観変 } \\
\text { 化なし }\end{array}$ \\
\hline
\end{tabular}

\section{三菱瓦斯化学（株）}

合成樹脂開発部

国 100 東京都千代田区丸の内 2-5-2 (三菱ビル)

2: 03-283-4850 FAX 03-283-2642 


\section{ダイヤアロイ ${ }^{\circledR}$}

\section{エンジニアリングプラスチックアロイ}

「ダイヤアロイ」は三菱レイヨンが, 独自の相溶化 技術により開発したエンジニアリングプラスチックア ロイです. 当社では, ABS 樹脂, 塩ビ改質材, 耐衝 慗性アクリル樹脂で培ったグラフト重合技術と PBT 樹脂におけるガラス瀻維などの強化技術を発展させ, エンプラの改質ならびに多機能化に成功したもので す. 次の 7 つのシリーズがあります。

(1) A シリーズ PC/ASA 系アロイ

アクリル系ゴムを使用しているので耐光性に優 れ, 耐薬品性も良好です。

\begin{tabular}{|c|c|c|}
\hline & $\underset{\text { TA-25 }}{\text { TA 般タイプ }}$ & $\begin{array}{l}\text { FA-30 } \\
\text { 難燃タイプ }\end{array}$ \\
\hline 熱帘形温度 & 108 & 108 \\
\hline $\begin{array}{l}\text { 衝赘強度 } \\
(\text { ア } \mathrm{kg} \cdot \mathrm{cm} / \mathrm{cm}\end{array}$ & 55 & 15 \\
\hline 燃焼性 & $\mathrm{HB}$ 相当 & $V-0$ \\
\hline
\end{tabular}

(2) B シリーズ PBT/ABS 系アロイ

ポリカーボネート樹脂を超える耐熱性があり, かつ流動性が抜群です。

\begin{tabular}{|c|c|c|c|}
\hline & & $\begin{array}{l}\mathrm{TB}-903 \mathrm{GE} \\
\text { 一般タイプ }\end{array}$ & $\begin{array}{c}\mathrm{FB}-906 \mathrm{G} \\
\text { 難燃夕イプ }\end{array}$ \\
\hline \multirow{3}{*}{$\begin{array}{l}\text { 熱変形温度 } \\
\text { 衝擊強度 } \\
\text { 燃焼性 }\end{array}$} & \multirow{3}{*}{$\begin{array}{c}{ }^{\circ} \mathrm{C} \\
\mathrm{kg} \cdot \mathrm{cm} / \mathrm{cm}\end{array}$} & 105 & 170 \\
\hline & & 7 & 7 \\
\hline & & HB & $V-0$ \\
\hline
\end{tabular}

(3) C シリーズ PC/ABS 系アロイ

ASB のメッキラインでメッキ可能です. 耐熱 性, 耐衝軗性が高いので製品の薄肉化が可能で す.

\begin{tabular}{lc|c|c}
\hline & & TC-35 & FC-30 \\
& & 般タイプ & 難燃タイプ \\
\hline 熱変形温度 & ${ }^{\circ} \mathrm{C}$ & 118 & 103 \\
耐撃強度 & $\mathrm{kg} \cdot \mathrm{cm} / \mathrm{cm}$ & 30 & 45 \\
燃燒性 & & $\mathrm{HB}$ & $\mathrm{V}-0$ \\
\hline
\end{tabular}

(4) E シリーズ PPE 系アロイ

特殊グラフトゴムを使用しているので光沢が高 く，高温エージング性が良好です。

\begin{tabular}{|c|c|c|c|}
\hline & & 一般タイプ & 難燃タイプ \\
\hline 熱変形温度 & ${ }^{\circ} \mathrm{C}$ & 120 & 100 \\
\hline 衝擊強度 & $\mathrm{kg} \cdot \mathrm{cm} / \mathrm{cm}$ & 20 & 16 \\
\hline 燃焼性 & & HB & $V-0$ \\
\hline
\end{tabular}

高分子 38 巻 6 月甼增刊 (1989 年)
(5) $\mathbf{P}$ シリーズ ポリエステル/PC 系アロイ 耐衝慗性に優れ，特にウエルド強度が高い。

\begin{tabular}{lc|c|c}
\hline & & TP-30E & TP-50 \\
\hline 熱変形温度 & ${ }^{\circ} \mathrm{C}$ & 105 & 80 \\
衝撃強度 & $\mathrm{kg} \cdot \mathrm{cm} / \mathrm{cm}$ & 64 & 69 \\
\hline
\end{tabular}

(6) X シリーズ PBT/PPE 系アロイ オンライン塗装可能な $150^{\circ} \mathrm{C}$ 耐熱性があり, かつ非ナイロン系なので吸水による性能変化が ありません。

\begin{tabular}{|c|c|c|}
\hline - & $\mathrm{TX}-70$ & $T X-70 \mathrm{H}$ \\
\hline 熱変形温度 & 150 & 160 \\
\hline ヒートサグ $150^{\circ} \mathrm{C} \mathrm{mm}$ & 2 & 1 \\
\hline $\mathrm{kg} \cdot \mathrm{cm} / \mathrm{cm}$ & 20 & 16 \\
\hline
\end{tabular}

(*) 低荷重 $4.6 \mathrm{~kg} / \mathrm{cm}^{2}$

（7） SR シリーズ ポリエステル系軟翼アロイ 温度による剛性の変化がマイルドです. 流動性 が特に優れているのでバンパーなどの大型成形 に適しています。

\begin{tabular}{lc|c|c}
\hline & & SR-20 & SR-30 \\
\hline 熱変形温度 & ${ }^{\circ} \mathrm{C}\left(^{*}\right)$ & 75 & 80 \\
ヒートサグ & $120^{\circ} \mathrm{C} \mathrm{mm}$ & 5 & 5 \\
衛撃強度 & $\mathrm{kg} \cdot \mathrm{cm} / \mathrm{cm}$ & 破壤せず & 破壊せず \\
\hline
\end{tabular}

(*) 低荷重 $4.6 \mathrm{~kg} / \mathrm{cm}^{2}$

$$
\text { 三菱レイヨン (株) }
$$

エンジニアリング・ブラスチック部

-104 東京都中央区京橋 2-3-19

803-245-8716

西 530 大阪市北区中之島 2-3-18

206-201-9453

450 名古屋市中村区名駅 3-28-12

จ 052-561-6711

東京研究所 樹脂応用第二技術センター

(4) 241 崎市多摩区登戸 3816

z: 044-933-7221 


\section{タフテック ${ }^{\circledR}$}

\section{飽和型熱可塑性エラストマー}

\section{1. 技術の背詈}

熟可塑性エラストマー (TPE) は, 常温ではゴムと しての特性を示し, 高温では可塑化されてプラスチッ クと同様に成形できる新しい機能材料である，姐化成 では TPE の代表商品であるスチレン系 TPE (TPS) のトップメーカーとして市場ニーズに応え，技術蓄積 を図ってきた。しかし，この TPS はソフトセグメン 卜に不飽和基を有するので, 耐候・耐熱性が要求され る高性能用途への対応には限界がある。

そこで，この不飽和基を選択的に水添して耐㑇・耐 熱性を大幅に改良した新しい飽和型 TPE の開発に着 手し，画期的な高活性水添触媒の開発と世界初の低 圧・無脱灰法水添プロセスの確立に成功し，1987 年に 工業化，「タフテック」として販売を開始した。

\section{2. 特長および用途}

「タフテック」は，ゴム弾性を示す水添ポリブタジ エンセグメントと物理架橋機能を有するポリスチレン セグメントを持つ独自構造のブロックポリマーであ り，主鎖に不飽和基を含まないのて，従来の TPS の 特性はそのまま保持して耐候・耐熱性が大愊に改良さ れた TPEである。

「タフテック」の製品種としては，樹脂改質材，粘 接着剤などに好適なポリマータイプ ( $\mathrm{H}, \mathrm{M}$ シリーズ) と, 各種成形品用途に好適なコンパウンドタイプ (K, $\mathrm{E}, \mathrm{S}$ シリーズ）があり，用途に応じて選択できるよ うに各種グレードを品揃えしている.

「タフテック」の基本特性は, (1)耐候性, 丽熱性に 優れ，物性バランス，ゴム特性に優れる，(2)無色透明 (除く $\mathrm{K}$ シリーズ) で, 安全性, 衛生性に優れる, (3) 耐薬品性, 電気特性, 低温特性に優れ, 使用温度領域 が広い, (4)加工性に優れ，一般のプラスチックと同様 に成形可能で,リサイクル使用が可能などである。

ポリマータイプは, これらの基本特性に加えて, (a 各種樹脂などとの相溶性に優れる, (粘着特性に優れ るなどの特徴があり, 衛材関係の粘接着剤, シーラン ト. 樹脂改買材, フィルムなどに好適に用いられる.

さらに，Mシリーズは，ポりマー鎖中に特殊な官能 基を導入した世界初の反応性 TPE で，グラフト反応 やポリマー反统が可能な特性に加えて, (a)ンプラに 対する相溶性が極めて高い, (b粘接着特性が大幅に向 上し, 各種金属, 各種樹脂に強力に接着するなどの特 性が付与されており,エンプラ改質材, ポリマーアロイ 相溶化材や FRP，エポキシ改質材などに好適である。

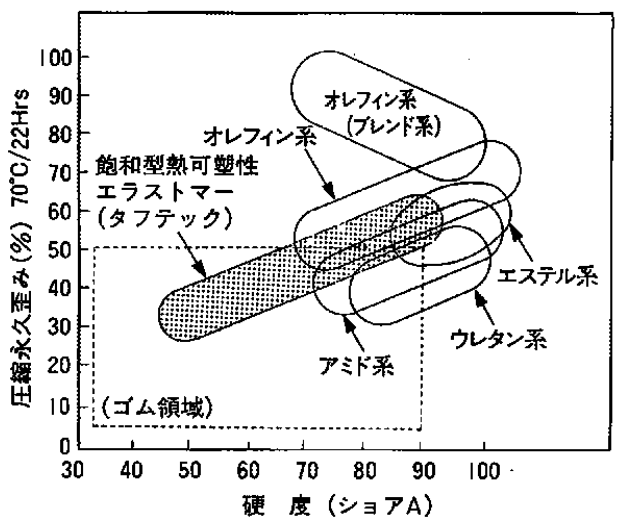

图 各程熱可塑性エラストマーの位置付け

一方「タフテック」コンパウンドは独自に設計し たベースポリマーに, 各種樹脂, 可塑郕などを配合し た成形用の高性能 TPE 製品で, 一般工業部品用の $\mathrm{K}$

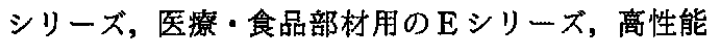
化・高機能化したSシリーズを揃えている，これらは， 先の基本特性に加えて, (a王縮永久歪みが小さく, TPE の中で最も加硫ゴムに近い性能バランスを示す, (b)着色, 硬度調整が自由にできる, (C)他樹脂との複層 成形ができるなど, 成形加工性とコストパフォーマン スに優れており, 自動車内外装部品, 医療部品, 食品 工業部品, 家電・ $\mathrm{OA}$ 機器部品, スポーツ部品, 各種 工業部品などに好適に用いることができる.

\section{3. 将来の展望}

「タフテック」は, 新しい飽和型 TPE として市場 での期待も大きいエラストマー機能素材である. 今後 もニーズに対応した新グレード開発と高品質化, 新用 途創出を積極的に推進する所存である。

\section{旭化成工業 (株)}

(《) 100 東宗都千代田区有楽町 1-1-2

203-507-2530 合成ゴム販壳第二部 30

(330 大阪市北区堂島浜 1-2-6

206-347-3774 合成ゴム担当

④60 名古屋市中区錦 2-2-13

2052-212-2153 合成ゴム担当 


\section{UBE-FRR}

\section{短織維強化ゴム}

\section{1. 技術の背景}

近年ゴム材料においても，高付加価值製品あるいは 新規用途向けに高機能の材料が強く要望され，これに 対応する研究開発が注目されている.

UBE-FRR はゴムマトリックス（母材）とポリマ 一短緎維（強化材）から成る短繊維強化ゴム材料であ る. 特に強化材の種類, 形状, 分散状態抢よび母材ゴ ムとの界面結合を重要視して, 当社独自の新規技術に より開発された. UBE-FRR 配合材料は数々の優れ た性質をもっており, 高性能ゴム製品・部品への好適 な使用が期待される.

\section{2. 性状および使用方法}

母材ゴムに天然ゴムと EPDM を用いた 2 種類があ り，いずれも強化材は超微細ナイロン短繊維である. 短瀻維は特殊処理により母材ゴムと強固に界面結合さ れここれによって母材中に細かく均一に分散してい る. UBE-FRR の種類と性状を下表に示す.

\begin{tabular}{|c|c|c|}
\hline 種 & UBE-FRR NR & UBE-FRR EPDM \\
\hline \multirow{2}{*}{ 材料組成 } & 天然ゴム 100 部 & EPDM 100 部 \\
\hline & ナイロン 65 & 50,100 部 (重量) \\
\hline 界面 結 合 & \multicolumn{2}{|c|}{ 化学的にグラフト結合 } \\
\hline 緎維平均径 & \multicolumn{2}{|c|}{$0.2 \sim 0.3 \mu \mathrm{m}$} \\
\hline アスペクト比 & \multicolumn{2}{|c|}{$>50$} \\
\hline 製 品 形 態 & シート状 & シート,チップ状 \\
\hline
\end{tabular}

UBE-FRR は母材ゴムに対してナイロン短瀻維が 重量比で 50/100, 100/100 の高充填系であるため, 用 途に応じてこれをそのまま，もしくは同種ゴムまたは 他材料とブレンドし，ナイロン短織維の含量を調整し て使用される.配合, 加工および加硫などは通常のコ ム材料とまったく同じ方法で行うことができる.

\section{3. 特徵および用途例}

上記の性状を反映して, UBE-FRR 配合物は次の

ような特徴を示す

・繊維含量が増すにつれて, 高いグリーンモジュラス と強度を示す, 他方, 配合物のムーニー粘度はほと んど変らないか, 増大の程度が小さい，また，ダイ スウェルが小さい. したがって, 形状保持性, 寸法 安定性が極めて良好であり, 押出加工時の表面肌に 優れる.

・高い弾性率をもつ加硫物が得られる，わずか $3 \mathrm{phr}$ の織維がカーボンブラックの $20 \mathrm{phr}$ 増量に相当す る補強効果を与える. また, 繊維含量の調整により

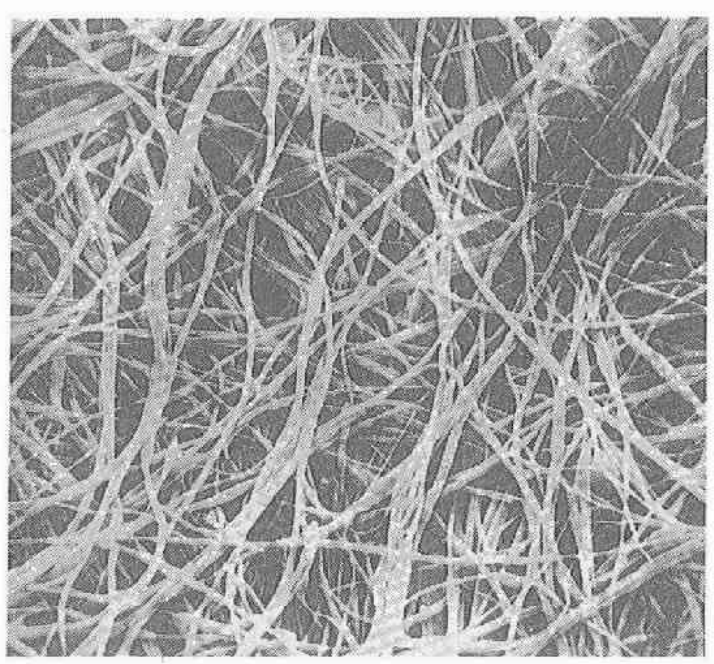

UBE-FRR NRから抽出されたナイロン短織維の SEM 写真

弾性率を広範囲に変えることが可能である.

- 同一硬度レベルで比較して, UBE-FRR 配合加硫 物はカーボンブラック增量系より高い反発弾性を示 す。また，低発熱性である。

・耐熱老化特性に優れる. 熱老化後の引張強さおよび 伸びの保持率が高く, 一方, 硬度の変化率は低い.

・耐油性が幾分改良されている。

・㵶維強化物特有の異方性が現われる.

これらの特徴を生かして種々の用途開発が図られて おり，次の例が揭げられる。

・自動車, 自転車用タイヤ部材.

・ラジェーターホース, ヒーターホース, 防振ゴムな どの自動車用部品.

・ベルト，ホース，ロール，スポンジなどの工業用ゴ 么製品。

・シューズ，ボールなどのスポーツ用ゴム製品.

・プラスチックス, ゴムの物性改良材.

\section{宇部興産 (株)}

研究開発本部市場開発第二グループ

夰107 東京都港区赤坂 1-12-32 アーク森ビル z 03-505-9235 


\section{UBE ポリアミドエラストマー}

\section{ポリエーテルブロックアミド樹脂}

\section{1. 技術の背晎と市場の勤向}

UBE ポリアミドエラストマーは，宇部興産が長年 培ったポリアミド分野での合成技術を基盤として，独 自の技術により開発したポリエーテルブロックアミド 樹脂である. UBE ポリアミドエラストマーは, ポリ アミドのエンプラとしての特長である成形性, 耐熱 性, 而薬品性と,ゴムの特長である柔軟性, 而衝撃性, 防振防音性を兼和備えた新しい熱可塑性樹脂である.

近年，自動車，笔機，機械，建材などの分野で，金 属から合成樹脂への素材の切り替えが進んでいる，そ のなかで, エンプラの特性とゴムの特性の境界領域を 補う材料の市場ニーズは強い。このような背累からエ ンプラ系エラストマーの市場の需要推移は, エンプラ が 7 8\%，合成ゴムが 3 4\%の年間使用量の伸び率 と推定されるているのに対し，エンプラ系エラストマ ーは 15〜20\%で推移すると予想されている.

\section{2. 構造と物性}

UBE ポリアミドエラストマーの一般式を次に示す。

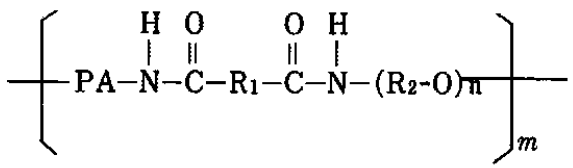

$\mathrm{PA}$ ：ポリアミド成分 $\mathrm{R}_{1}, \mathrm{R}_{2}$ :アルキンン基

一般式の中でポリアミド構成成分がハードセグメン トとして, ポリエーテル構成成分がソフトセグメント として機能している.

グレードとしては，ポリアミド成分がポリアミド 6 で構成される PAE600 シリーズと，ポリアミド12で 構成される PAE1200 シリーズがある。いずれも柔軟 性と耐熱性を兼ね備えている。表 1 に代表的な UBE ポリアミドエラストマーの基本的な性賀を示す。

\section{3. 特幑および用途}

UBE ポリアミドエラストマーの特徴を以下に述べ る.

（1）優れた耐油性，耐薬品性を有する.

(2) 強靯である。

（3）成形性（射出，押出）に優れる.

（4）耐熱性，耐寒性に優れる.

（5）優れた弾力性，屈曲疲労抵抗性を有する.

これらの特徵を利用して,プラスチックとゴムの境 界領域を補う分野へ多く利用されている，例皃ば，自 動車のウィンドモール，スポーツシューズのソール，
衰 1 UBE PAE シリーズの代表的な性質

\begin{tabular}{|c|c|c|c|c|c|}
\hline \multirow{2}{*}{ 性 } & \multirow{2}{*}{ 質 } & \multirow{2}{*}{ 単位 } & \multirow{2}{*}{$\begin{array}{c}\text { PA } 6 \text { 系 } \\
\text { PAE } \\
600\end{array}$} & \multicolumn{2}{|c|}{ PA 12系 } \\
\hline & & & & $\begin{array}{c}\text { PAE } \\
1200\end{array}$ & $\begin{array}{l}\text { PAE } \\
1200 \mathrm{~S}\end{array}$ \\
\hline 比 & 重 & - & 1.04 & 1.00 & 1.17 \\
\hline 融 & 点 & ${ }^{\circ} \mathrm{C}$ & 198 & 154 & 157 \\
\hline \multirow{2}{*}{ 吸水率 } & $\begin{array}{l}23^{\circ} \mathrm{C}_{\mathrm{k}} \\
65 \% \mathrm{RH}\end{array}$ & \multirow{2}{*}{$\%$} & 1.7 & - & - \\
\hline & $\begin{array}{l}23^{\circ} \mathrm{C} \text { 水中, } \\
24 \mathrm{hr}\end{array}$ & & - & 0.5 & 0.4 \\
\hline \multicolumn{2}{|c|}{$\begin{array}{c}\mathrm{MFR}\left(\mathrm{a}: 190^{\circ} \mathrm{C}\right. \\
\left.\mathrm{b}: 235^{\circ} \mathrm{C}\right)\end{array}$} & $10 \mathrm{~min}$ & $50 \widetilde{b}$ & $10 \sim$ & 6 $13 \mathrm{a}$ \\
\hline \multicolumn{2}{|c|}{ 引張り強さ } & $\mathrm{kgt} / \mathrm{cm}^{2}$ & 110 & 90 & 130 \\
\hline & $\%$ & $>300$ & $>300$ & $>300$ \\
\hline \multicolumn{2}{|c|}{ 曲げ強さ } & $\mathrm{kgf} / \mathrm{cm}^{2}$ & 130 & 70 & 90 \\
\hline \multicolumn{2}{|c|}{ 曲引゙弾性率 } & $\mathrm{kgf} / \mathrm{cm}^{2}$ & 3,300 & 1,500 & 1,800 \\
\hline \multirow{2}{*}{\multicolumn{2}{|c|}{$\begin{array}{cc}\text { 衝繁強度 } & 23^{\circ} \mathrm{C} \\
& -40^{\circ} \mathrm{C}\end{array}$}} & $\begin{array}{l}\mathrm{kgf} \cdot \mathrm{cm} \\
\mathrm{cm}\end{array}$ & NB & NB & NB \\
\hline & & $\begin{array}{c}\mathrm{kgf} \cdot \mathrm{cm} \\
\mathrm{cm}\end{array}$ & 24 & 14 & - \\
\hline \multicolumn{2}{|c|}{ かたさ (ショアD) } & - & 60 & 56 & 58 \\
\hline \multicolumn{2}{|c|}{$\begin{array}{l}\text { 熱変形温唐 } \\
\left(4.64 \mathrm{~cm}^{2}\right)\end{array}$} & ${ }^{\circ} \mathrm{C}$ & 71 & 82 & 84 \\
\hline \multicolumn{2}{|c|}{ 燃焼性 (UL-94) } & - & (HB) & (HB) & $\mathrm{V}-0$ \\
\hline
\end{tabular}

テニスラケットのグロメット. VTR やオーディオ機 器の消音効果を目的とするギア，産業機械に使用され るチューブやホース類などがあげられる．また難燃グ レードを用いた酎圧チューブや，他の樹脂の改質材と しての用途など特異な展開も進められている.

\section{4. 将来の動向}

UBE ポリアミドエラストマーは, 当分の間, プラ スチックとコムムの中間をうめる素材として用途展開さ れると思われるが，今後ゴム領域の弾性が実現でき， コストダウンが可能となれば，その成形の容易さから 用途は拡大されると推定される。 また，エラストマー の特徴を生かし，織維分野への用途拡大も期待され る.

\section{宇部興産 (株)}

ナイロン樹脂事業部技術部

通 107 東京都港区赤坂 1-12-32 アーク森ビル 8. 03-505-9357 


\section{クラプレン LIR}

\section{液状ポリイソプレンゴム}

\section{1. 背黑}

わが社は，特殊な重合法により新規イソプレン系溜 状ゴムを開発し，クラプレン LIR-30，50 として上市 した，その後，カルボキシル基，水酸基を有するタイ プを LIR-400，500 シリーズとして相次ぎ開発し上市 している.これらの各種 LIR は，ジェン系ゴムとの 相溶性に優れることから，タイヤを初めとする各種ゴ 么製品の, 非移行性, 非抽出性の反応性可塑剂, 天然 ゴムなどをべースとする粘着剤の，非ブリード性の低 温性能に優れる高分子量可塑㓮として，また，高純度 のイソプレンポリマーとして各種反応の原料としても 使用されている，カルボキシル基を有するタイブは， ゴムと金属などの材料との接着性を改良する改筫郕と して使用されている他，官能基を利用し架橋すること により，シーリング材，コーティング材，あるいは， 後架橋型の粘着剤にもその応用が広まっている，水酸 基を付加したタイプは，イソシアナートにより架橋で き, ウレタンの分野を中心に応用されている.

\section{2. 新規開発液状イソプレンゴムの特性}

従来のイソプレン系液状ゴムは上述のとおり，ユニ 一クな特性を示すものの，他のジエン系の液状ゴムと 同様，分子鎖中に存在する二重結合により，耐熱性， 耐候性が不十分という久点がある。そこで，この点に 注目した水添ポリイソプレンコムを開発した。さる に，他のモノマーとの共重合により新たな機能を付与 した，共重合液状ゴムを開発した。

2-1. 水添ポリイソプレンゴム

LIR-290 は, 液状イソプレンゴムの二重結合の 90\%を水添したものであり，優れた耐熱性，酎候性を もつと同時に, EPDM などの極性の低いコムと十分 な相溶性を有し，さらに残存する二重結合により，よ り加硫が可能という性質も併せ持つ，EPDM，IIR な どにブレンドし使用することにより，成型加工時には 可塑効果を示し, 加硫後はベースのゴムと共加毓し得 ることから，強度の性能を低下させることがなく，ブ リード，抽出されることのない，反応性可塑威として 優れた特性を示す，また，ポリイソプレンの水添物は エチレンープロピレン交互共重合体の構造となり，ポ リオレフィンとの相溶性にも優れ, PE, PP などのポ リオレフィン, SEBS などの飽和系のポリマーの改質 唷としての応用も可能である，ポリオレフィンの低温 特性改良剤, SEBS ベースとした粘着剤の低温特性の 改良効果が得られる。
クラブレン LIR の性状

\begin{tabular}{|c|c|c|c|}
\hline LIR & グレード & ${ }^{\text {分子量 }}$ & 官能基䜳 \\
\hline 水 & 290 & 25,000 & - \\
\hline IP-BD 共重合 & 390 & 40,000 & - \\
\hline IP-ST 共重合 & 310 & 31,000 & - \\
\hline 標 潐 品 & 30 & 29,000 & - \\
\hline$n$ & 50 & 47,000 & - \\
\hline $\mathrm{COOH}$ 付加物 & 403 & 25,000 & 3 \\
\hline " & 410 & 25,000 & 10 \\
\hline $\mathrm{OH}$ 付加物 & 503 & 25,000 & 3 \\
\hline$n$ & 506 & 25.000 & 6 \\
\hline
\end{tabular}

\section{2-2. 共塞合液状ゴム}

○イソプレン-ブタジエン共重合ゴム（LIR-390)

耐熱性に優れるジエン系液状ゴムという観点から， イソプレンーブタジエンブロック共重合体を開発した。 これは, ポリイソプレンとポリブタジエンとの熱劣化 挙動の差を利用した耐熱劣化性に優れたジエン系ゴム である．また，イオウ，パーオキサイドなどによる架 橋が可能であり，架橋物はゴム弾性に優れており， $200^{\circ} \mathrm{C}$ 程度, 1 時間の加熱後もゴム弾性を保持すると いう十分な耐熱劣化性を示す，特に，高温での耐熱劣 化性が必要とされる自動車用のシーリング材用の材料 として最適である。

○イソプレンースチレン共重合ゴム (LIR-310)

この LIR-310 は，スチレン系熱加塑性ポリマーと の相溶性に優れ，これをべースとした粘着剤の低温特 性を改良する，ブリードすることのない改質郕として 特に適している。

以上のように，さまざまな液状ゴムを開発している が，今後も，さらに新たな機能を有する液状ゴムを開 発中であり，今後も幅広い用途，分野に対応していき たい.

\section{(株)クラレ}

化学品第二事業本部

(3) 103 中央区日本橋 3-8-3 新日本橋ビル

803-277-3242 ポリマー販売部

显 506 大阪市北区梅田 1-12-39 新阪急ビル

806-346-2551 大阪販売部 


\section{住友 TPE}

\section{高品質熱可塑性エラストマー}

\section{1. 技術の偹墨}

オレフィン系熱可塑性エラストマー（以下 TPO と 略す）は，1972 年米国ユニロイヤル社が「TPR」と いう商品名で最初に上市した．住友化学はその技術を 導入して「住友 TPE」という名称て国内上市し，す でに 10 年余りを経過した。その間，自動車・家電・エ 業材料などの分野で，順調に市場を拡大してきた。

このほど住友化学では, ショアー硬度 $50 \mathrm{~A} \sim 60 \mathrm{D}$ の TPO 全域にわたり，従来の TPO より一段と高品 貿のグレードを品揃えすることに成功し，「住友 TPE」 3000 シリーズとして新上市することになっ た.

\section{2. 特徴および用途}

「住友 TPE」3000シリーズは, 従来タイプ TPOの 長所 (低比重, 耐寒酎熱性, 耐候性, 耐薬品性, 電気 絶縁性，䤰装着色性など）をそのまま保持した上で， 機械的物性のバランス, 成形加工性, 外観のいずれも 大偪に向上させたものである。

表 1 预よび図 1 に, 「住友 TPE」3000シリーズ主 要グレードの基本物性, ならびに従来タイプ TPO と の物性比較を示す。

用途的には，自動車（外装・内装・エンジンルーム 内部品), 家電, 各種工業材料, 雑貨, 電線などに展 開の予定である。

表 1 「住友 TPE」3000 シリーズ 主要グレードの一般物性

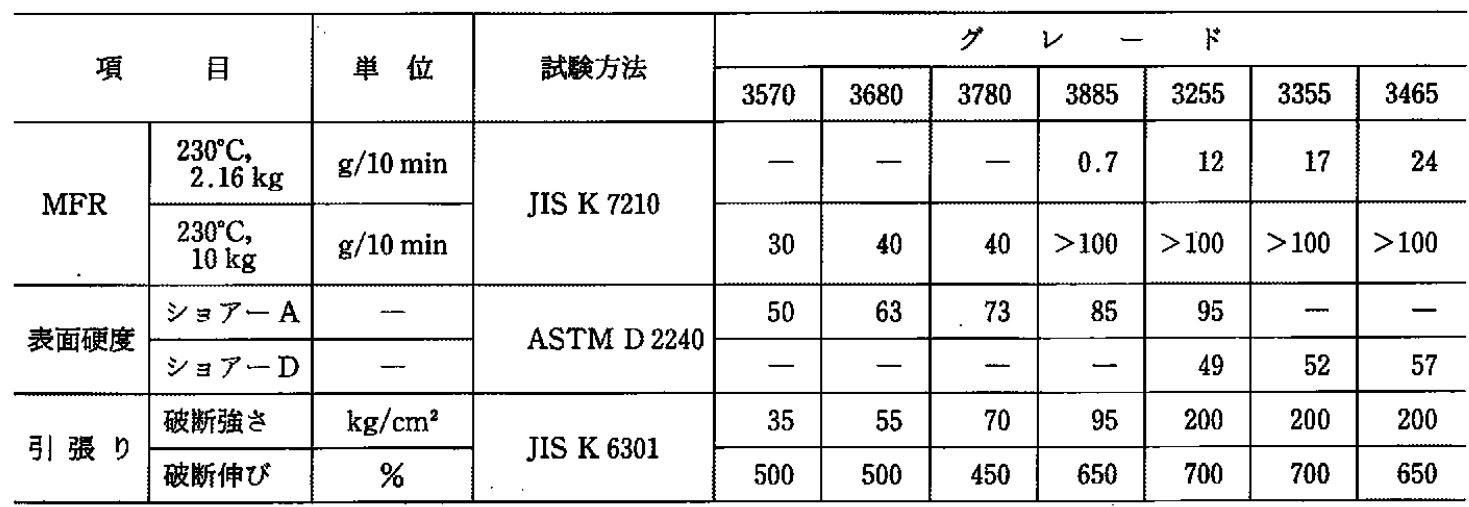

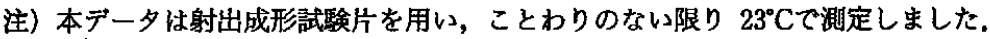

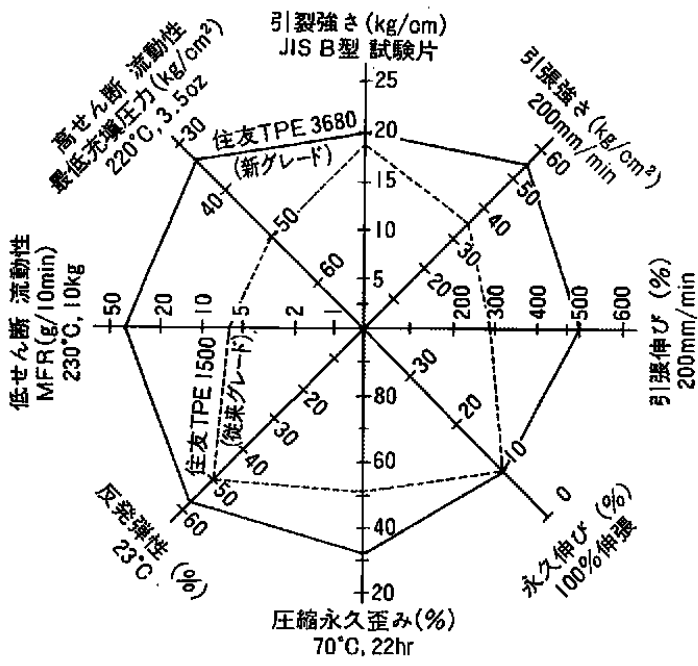

図 1 射出成形品物性の比較

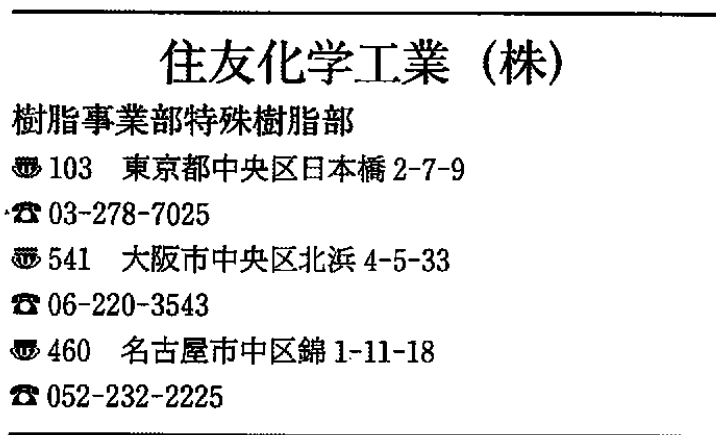

高分子 38 巻 6 月号增朋 (1989 年) 


\section{ダイエル ${ }^{\circledR}$}

\section{フッ素ゴム}

ダイキン工業は，1970 年ビニリデンフルオライドヘキサフルオロプロピレン系フッ素ゴム“ダイエル” なる商品名で初めて国産化して以来, 長年培ったフッ 素化学技術を生かし, 各分野のニーズに応えた品種を 開発してきました。

ダイエルは, 卓越した耐熱性, 耐油性, 耐薬品性を 有しており，近年の自動車工業界をはじめとする各産 業界より, 苛酷な使用条件やメンテナンスフリーの要 求加, また優れた機能性, 経済性の面から需要が増 加してきています

\section{1. 組成と性質}

ダイエルは，圧縮永久ひずみの小さいVDF-HFP の二元共重合体, および極性溶媒に強い VDF-HFPTFE の三元共重合体が主流となっています.

最近開発されたダイエルサーモプラスチックは, フ ッ素ゴムとフッ素樹脂のハイプリットで, 加工性, 成 形品の透明性, 耐薬品性などを有しています.

またダイエルパーフロは, TFE-パーフルオロピニ ルエーテルの共重合体であり, 弾性のあるフッ素樹脂 ともいえる新しいフッ素ゴムで, あらゆる薬品, 溶剤 に対して最高の耐薬品性を示します。

\section{2. タイエルの品種}

ダイエルの代表的品種を表 1 に示します

\section{3. 特徵および用途}

VDF-HFP 共重合体は, 耐熱性, 耐油性, 耐薬品 性など特性のバランスが良く，加工性も良いので幅広 い分野に使用され，特に圧縮永久ひずみが最小である ため，O-リングを始めとするシール材に多く使用さ れています。

VDF-HFP-TFE 三元共重合体は，さらにフッ素含 有量を增やして，耐ガソホール(アルコール混合ガソ リン) や薬品性が向上しています。

タ゚イエルサーモプラスチックは，世界で初めて開発 した熱可塑性フッ素ゴムであり, 常温てはゴム弾性を 示し, 融点以上の高温では熱可塑性プラスチックと同 様の挙動を示しますこのため成形加工性は熱可塑性 樹脂, 常態物性はフッ素ゴム, 耐薬品性はフッ索樹脂 に類似するという多面的特長を持っており, 各分野で シール材として使用されています。

ダイエルパーフロは, 炭素, フッ素, 酸素原子のみ で構成されておう，従来のフッ素ゴムでは耐性がなか ったケトン類, フラン類, エステル類やエーテル類に 而える特性を有しており, 分析, 理化学機器, 半導体

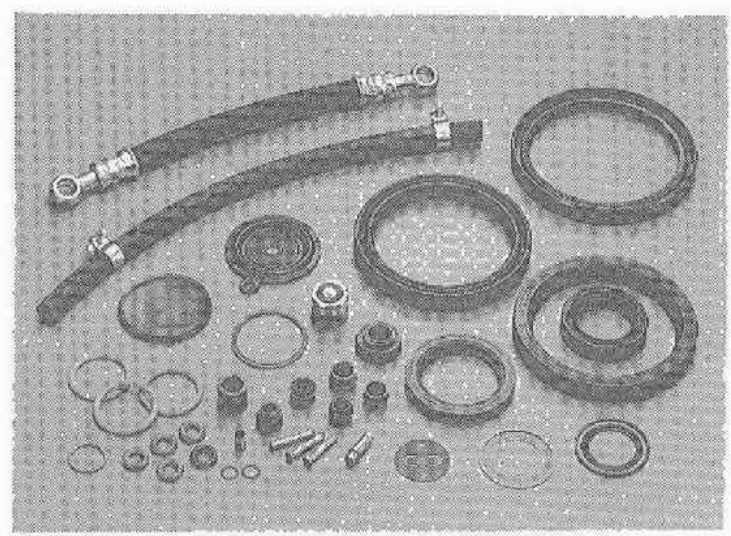

表 1 ダイエルの代表的品種

\begin{tabular}{|c|c|c|c|}
\hline ポリマー 加䃄系 & ポリアミン & ボリオール & パーオキサイド \\
\hline 二 元 & - & $\begin{array}{l}\text { G-701 } \\
\text { G-751 } \\
\text { G-755 } \\
\text { G-763 }\end{array}$ & $\mathrm{G}-801$ \\
\hline 三 元 系 & $\begin{array}{l}\text { G-201 } \\
\text { G-501 }\end{array}$ & $\begin{array}{l}\mathrm{G}-555 \\
\mathrm{G}-602 \\
\mathrm{G}-621\end{array}$ & $\begin{array}{l}\text { G-901 } \\
\text { G-902 }\end{array}$ \\
\hline 液状コム & \multicolumn{3}{|l|}{ G-101 } \\
\hline ラテックス & \multicolumn{3}{|c|}{ GL-152, GL-252, GLS-213 } \\
\hline サーモプラスチック & \multicolumn{3}{|c|}{$\mathrm{T}-530, \mathrm{~T}-630$} \\
\hline パーフロ & \multicolumn{3}{|c|}{ GA -50, GA-55 } \\
\hline
\end{tabular}

関係などの分野に利用されています。

\section{4. 将来の展望}

各産業分野よりフッ素コムに対して, コスト面, 成 形加工面, 特性面から種々の要求が強まっている.

フッ素ゴムは, これらの要求, ニーズに応じた品種 の開発や成形加工法の開発により，さらに用途拡大が 期待できよう.

\section{ダイキン工業（株）}

化学事業部営業企画部

本社

\$530 大阪市北区中崎西 2-4-12 (梅田センタービル) שా 06-373-1201（代表） 


\section{チッソエラスリット, チッソエラストダル}

\section{塩化ビニル樹脂系エラストマー}

\section{1. まえがき}

熱可塑性エラストマーとは常温でゴム状弾性を示す が，高温では可塑化され成形可能な高分子化合物のこ とである，そしてゴムと比較した場合その特徴は

（1）従来の熱可塑性樹脂用加工機械で成形加工でき る.

（2）加硫工程が不要である.

(3) リサイクルが可能である.

2. 塩ビ系エラストマーについて

塩ビ系エラストマーは上記特徴とともに価格の手頃 さのために近年急速に㲸用化してきた。

塩ビ系エラストマーと他の熱可塑性エラストマーと 比較した場合の特徵は

（1）一次加工時に扔ける生産性が良好である，例えば 押出成形における吐出量, 射出成形におけるサイク ル時間などは塩ビ系エラストマーが良好である。

（2）二次加工性が良好である。例えば，フィルム，シ ートに対する印刷性，ウェルダー加工，接著性加工 などは他エラストマーに比べて容男である。

（3）調色の自由度, 透明性に優れているのでファッシ ヨナブルな用途に適している。

3. チッソエラスリットについて チッソエラスリットは上記塩ビ系エラストマーの特 徵に加えて次のような特徵を有している.

（1）押出，射出分野で硬度 40〜90 度（ゴム硬度）と 広範囲をカバーしており，多用途に対応できる。

（2）特殊配合によりゴム状弾性（圧縮永久昰み，反発 弾性，etc）が優れ，また耐寒性も良好である $\left(-60^{\circ} \mathrm{C}\right)$.

（3）塩ビ系菜材の特徵である難燃性，耐熱性，耐オゾ ン性，耐薬品性などについてはさらに配慮がなされ ており，ユーザーの要求性能により，さらなるグレ ードアップも可能である。

4. チッソエラストダルについて

エラストダルはチッソが他社に先がけて開発した靘 消し高弾性体特殊コンパウンドである。従来成形品の 艶を消すためには，シボうちするか，低温加工する か，あるいは哑消し澄料を塗布する方法が用いられて いた.

エラストダルは，原料そのものが艶消し素材である ので, 二次加工の必要もなく，通常の成形条件で美麗 でかつしなやかな数消し製品が得られる，特に本質的 に光の反射を嫌いうァッション性を重視する自動車内
装部品や壁装材に最邂な素材といえよう。

5. エラスリット，エラストダルの成形法

(1) 射出成形

$\mathrm{PP}, \mathrm{PE}$ など㛙可塑性樹脂と基本的に違う操作は

(1)作業終了時にシリンダー内を $\mathrm{PE}$ などの他樹脂で

置換しておくこと。

(2)金型を防錆して招くこと

この基本さえ, 遵守したら他は全く他の熱可塑性樹 脂と同じ操作条件でよい。

(2) 押出成形

塩ビ専用機が望ましいが，ポリオレフィン用を用い るときはスクリューは浅潬のものと交換する。スクリ ューは $L / D=22$ 以上, 圧縮比 2.5 以上のものが望ま Uw.

\section{6. 用途}

䅺近，塩ビ系エラストマーは機能性が高い割には価 格が手頃なことより㲸用化し, 自動車内外装部品, 建 材用 (ガスケット, 防振材), 家電部品, 履物類, 木 一ス，電線被覆材などに用いられている。

$$
\text { チッソ (株) }
$$

⑩0 東京都千代田区丸ノ内 2-7-3 東京ビル $4 \mathrm{~F}$ 803-284-8569 FAX 03-284-8548 


\section{JSR アフラス}

\section{フッ素ゴム}

フッ素ゴムは他のゴムに比へて耐熱性・耐油性に優 れ, 自動車・航空機・機械・化学プラントなどの分野 で高性能・高機能ゴム部品用素材として使用されてい る. 今後もこれらの分野をはじめとしてゴム部品の使 用環境はますます厳しくなることが予想され，フッ素 ゴムの重要性はさらに增大するものと考えられる.

$\mathrm{JSR}^{\circledR}$ アフラスは, フッ素ゴムの中でも非常にユニ ークな性能を有する素材であり，既存のゴム素材では 対応できなかった分野への応用の可能性を有してい る.

\section{1. アフラスの構造および加工}

アフラスの構造と代表的配合内容を以下に示す.

1）構造：テトラフルオロエチレンとプロピレンの交 互共重合体であり，他のフッ素ゴムより比重も小さ w.

$$
\begin{array}{r}
-\mathrm{CF}_{2}-\mathrm{CF}_{2}-\mathrm{CH}_{2}-\mathrm{CH}_{\pi} \\
\text { I } \\
\mathrm{CH}_{3}
\end{array}
$$

2）配合内容

（i）カーボンブラック補強のみで十分な強度を有 し，比較的単純な配合組成で使用できる.

（ii）架橋剤は有機過酸化物であり（パーオキサイ ド加硫), 架橋剤の反応生成物などのゴムへの残留 はほとんどない.

\section{2. アフラスの特徵}

アフラスの一般的な特徴を以下に示す.

1）耐熱性に優れる。( $\left(250^{\circ} \mathrm{C}\right.$ の長時間使用に耐える)

2）電気絶縁性に優れる.（他のフッ素ゴムの約 100 倍)

3）耐油性・耐水性に優れる.

4）而藥品性に優れる.（潤滑油の性能向上のための添 加物剤などに対しても，他のフッ素ゴムにない優れ た耐性を示す，図 1 および図 2 参照)

以下にアフラスが耐える薬品の概要を示す.

(酸)

硫酸・硝酸・塩酸など強酸, ギ酸など有機酸

(アルカリ)

水酸化ナトリウムなど強アルカリ，アンモニア水

(各種塩類)

強酸塩, 弱酸塩, 次亜塩素酸塩, フッ踆塩, フェノ 一ル塩

(その他)

硫化物, アルコール類, アルデヒド類, フェェノール 類, アミン類

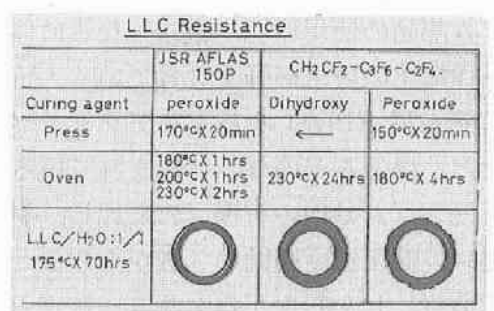

図 1 耐ロングライフクーラント性 (アフラスと通常 フッ素ゴムの比較)

通常のフッ素コムは劣化溶解している.

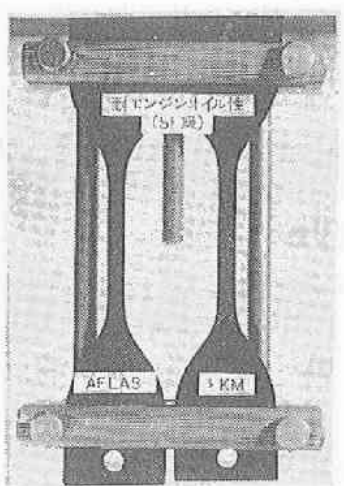

図 2 耐 SF 級エンジンオイル性 $\left(175^{\circ} \mathrm{C} \times 70 \mathrm{hr}\right)$ (アフラスと通常フッ素ゴムの比較)

通常のフッ素コムには無数の龟裂が発生している.

3. アフラスの用途

以上の特性を生かした用途例を次に示す

1）薬品タンクローリー, 電解槽, メッキ槽, 纎維漂 白槽, エンジン関係のパッキン, ガスケット，Oリングおよびシャフトシール。

2) 排煙脱硫装置, 耐酸バルブ, スチームパルブなど のバルブ弁座およびダイヤフラム。

3）電線被覆材.

4）複写機，酸洗浄機械などのロール.

5）自動車用オイルホースなど耐油性・耐薬品性の必要 なホース, チューブ, ベルトなど.

\section{日本合成ゴム (株)}

合成ゴム事業本部特殊ゴム販売課

昰104 東京都中央区築地 2-11-24

z 03-541-4111 夜間直通 03-545-4029

大阪支店 ت706-203-0041

名古屋支店 20052-571-1231

広島支店 $80082-221-7252$ 


\section{JSR JENIX E}

\section{シリコーン複合ゴム}

近年ゴム部品の使用環境が厳しくなるに伴い,ゴム 素材の高性能化の要求が強くなっている. 特に使用温 度範囲の拡大が EPDM をはじめアクリルゴム, フッ 素ゴムなど，ほとんどのコムに望まれている。

シリコーンゴムは他の有機ゴムに比し，耐熱性・耐 寒性に優れ, 使用温度範囲の広さからみると理想に近 いコムである。しかしながらシリコーンゴムは機械的 強度が小さい, 而熱水性・耐スチーム性に劣るなどの 欠点を有する。

有機ゴムとシリコーンゴムをうまく複合化すれば， 有機ゴムの使用温度範囲の拡大とともに，シリコーン ゴムの久点・弱点を改良することも可能となろう.

このような見地から開発された JSR ${ }^{\circledR}$ JENIX E (シリコーン/EPDM 複合ゴム) を中心にシリコーン 複合ゴムについて紹介する。

\section{JENIX E の特徴}

シリコーンと EPDM の複合ゴムである JENIX E の特徵をシリコーンゴムおよぴ EPDM との比較で示 す.

1) EPDM との比較

i ) JENIX E は耐熱性に優れる.（図 1 参照）

ii）機械的強度は EPDM と同レヘルである.

iii） JENIX E は機械的強度の温度依存性が小さく, 高温時の引張強さ, 引裂強さが大きい,

2) シリコーンコムとの比較

i ) JENIX E は機械的強度に優れる.

ii）JENIX E は而墂水性・耐スチーム性に優れる.

iii）電気特性（絶縁抵抗）は EPDM; シリコーン ゴムと同様に優れる.

\section{JENIX E の用途}

以上の特性を生かした用途例を次に示す.

i ) 自動車用の各種キャップ，プーツ類

ii）自動車用ラジエータ・ヒーターホース

iii）電気器具の各種部品（アノードキャップなと゚）

iv）電線の絶縁およびシース材

v) ソーラー部品

vi）乾質のゴムロール

vii）キーポード

これらのなかの二, 三の製品例を図 2 に示す

\section{3. シリコーン複合ゴムの展開}

上述の JENIX E 以外にも, 例えぱアクリルゴムゃ フッ素コムとシリコーンとの複合ゴムも下記の特性か゚ 期待される.

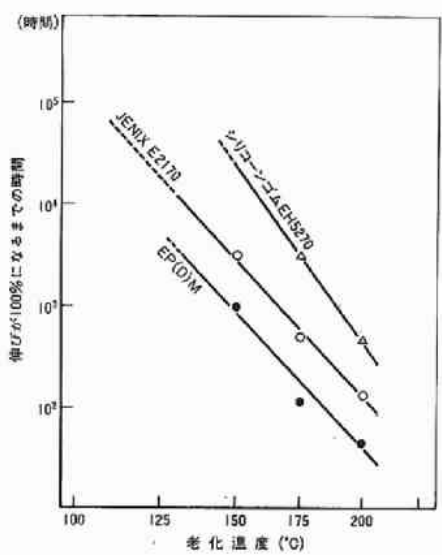

図 1 老化温度と伸びが $100 \%$ になる までの老化時間の関係

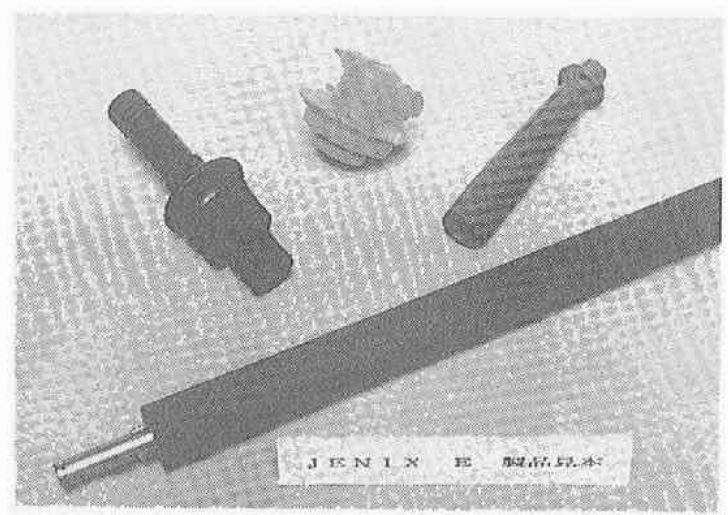

図 2 JENIX E の製品見本

i ）アクリルゴム，フッ素ゴムの耐寒性改良

ii）アクリルゴムの耐熱性改良

iii）シリコーンゴムの機械的特性や耐油性の改良

これらの複合化は兩者の相溶性が悪く困難をきわめ たが，当社ではこれをブレークスルーする新規な複合 化法を見いだしており，実用化検討中である.

\section{日本合成ゴム（株）}

合成ゴム事業本部特殊ゴム販売課

严104 東京都中央区築地 2-11-24

洛 03-541-4111 夜間直通 03-545-4029

大阪支店 Z 03-203-0041

名古屋支店 052-571-1231

広島支店 $8082-221-7252$ 


\section{Nipol SBR NS シリーズ}

\section{末端改質タイヤ用溶液重合 SBR}

\section{1. 技術の背暴と市場の動向}

現代の私達の生活において自動車は無くてはならな い必需品であり，そのバリエーションはますます増加 しています．自動車タイヤにおいても「高性能タイ ヤ」・「低燃費タイヤ」などが主流となり, 乗用車の夕 イヤのトレッド用ゴム材料に求められる品質特性も高 度化かつ複雑になってきています．これらのなかでも 時代の要求として特に求められるのは, 安全性と経済 性という二律背反の品質特性を同時に满足させるゴム 材料であります．乗用車タイヤのトレッド用ゴム材料 の代用特性で表せば，高いウェットスキッド抵抗と高 い反発弾性率を有することが重要です

日本ゼオンが新たに上市した「 Nipol SBR NS シリ ーズ」はこのような品質特性を満足すべく開発された 溶液重合 SBR であり, 既に国内外の多くのタイヤメ 一カーで好評を得ています。

\section{Nipol SBR NS シリーズの物性}

「Nipol SBR NS シリーズ」は高い反発を実現する ために，その重合触媒の特街を生かして，ポリマー分 子の末端に特殊な極性基を導入して抢り，この極性基 が混練の際に補強剤であるカーボンブラックの表面に 存在する極性基と相互作用をもち, カーボンブラック の分散を促し，かつ分散状態を安定化する効果を有し ます.

カーボンブラックの分散安定化の結果は, 従来の配 合物中で存在したカーボンブラックの凝集体が隇少 し，凝集体の破壊によるエネルギ一損失は少なくな

り，加硫物の反発弾性が高くなります。

このような特殊な極性基を導入した「Nipol SBR NS シリーズ」を用いた加硫ゴムは, 反発弾性だけで なく発熱性などのその他の動的性質も改良されていま す.

また，極性基はポリマー分子末端に一個導入されて いるだけであり，ウェットスキッド抵抗などの他の加 硫物性はほとんど影響されません。

Nipol SBR NS シリーズを用いた加硫ゴムの反発弾 性率 $\left(60^{\circ} \mathrm{C}\right)$ とウェットスキッド抵抗との関係を図に 示します。

Nipol SBR NS シリーズの優れた特徴が上の図から も明らかです。

\section{Nipol SBR NS シリーズの用途}

このように優れた特徵を有する Nipol SBR NS シ リーズは低燃費タイヤ・高性能夕イヤなどのトレッド

高分子 38 卷 6 月㤏增刊 (1989 年)

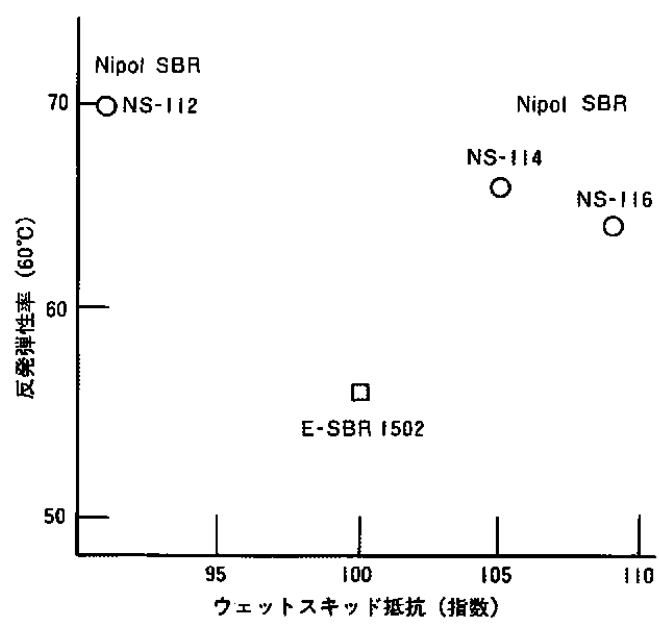

材料として好適であるばかりでなく，動的特性が優れ ているので防振ずム用材料としてもその特徴を生かす ことが可能であります。

\section{日本ゼオン（株）}

\section{ゴム事業部製品技術部}

\section{本社}

(e) 東京都千代田区丸の内 2-6-1

(古河総合ビル内)

203-216-2337 


\section{ゼットポール}

\section{高飽和型ニトリル系ゴム}

\section{1. 技術の背暴と市場動向}

耐油性ゴムの中で, 使用墨の多いニトリルゴム (NBR) やクロロプレンゴムの耐熱性が不足している 部分をエピクロロヒドリンゴム,アクリルゴム $(\mathrm{ACM})$ ，フッ素ゴム (FKM) などが補っている。し かし，これらのゴムにも固有の弱点があり, 性能上の バランスが取れているとはいえず，それぞれ限られた 用途に使用されている。

一方，自動車，航空機，産業用機械などの份野にお いては，公害規制，省エネルギーなどの社会的要誚 や. 技術革新に伴って，そこに使われる耐油性ゴム部 品の使用環境はますます厳しくなっている。このため 既存のゴム材料では十分耐えられなくなり，これまで 以上の初期性能と耐久性を持った耐油性のゴムの出現 が, 広く各方面から強く望まれている。

「ゼットポール」は, これら信頼性, 耐久性への要 求を認識して, 当社が世界で初めて開発した高耐久 性, 涌油性ゴムである。

なお，この「ゼットポール」を分子構造設計の段階 から工業的製造技術に到るまで，自社技術で開発した ことに対して昭和 61 年度日本化学会化学技術賞を受 賞した。

2. 構造と特性および品番 図 1, 表 1 参照.

\section{3. 特徴および用途}

「ぜットポール」は，NBR の耐油性を保持したま ま, 而熱老化性 (ACM 同等), 耐候性, 耐酸敗劣化ガ ソリン性 (NBR の 4 5 倍), 強度特性, 耐寒性 (FKM より約 $20^{\circ} \mathrm{C}$ 優れる)，化学薬品性などの諸特性 に優れ，現有する涌油性ゴムの中できわ立って高い性 能バランスを持つ。

以上のような優秀な性能が注目され，従来のゴムで は品貿上問題の多い分野で使用されている。

1) 自動車燃料油系ホース，ダイヤフラム，2)オイル クーラーホース, シール, パッキング，3) 自動車用夕 イミングベルト，ポりVベルト，4)石油堀削部品，5） その他のシール, パッキング, O-リング, ダイヤフ ラム,ベルト、ケーブル被覆，ロールなど.

\section{4. 将来動向}

高信頼性，長期酎久性を兼ね備えた新しいゴムとし て，世界的にも注目され，広汎な用途展開が図られ， 確固たる地位を築きつつある。

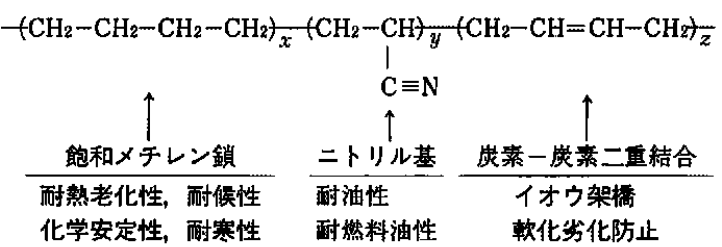

図 1 ゼットボールの構造と特性

表 1 ゼットポールの品番

\begin{tabular}{|c|c|c|c|}
\hline 品 番 & $\begin{array}{l}\text { 二トリル } \\
\text {.䒤量 }(\%)\end{array}$ & $\begin{array}{c}\exists \text { 絮価 } \\
(\mathrm{g} / 100 / \mathrm{g})\end{array}$ & 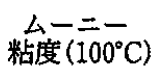 \\
\hline $\begin{array}{c}\text { ゼットポール } \\
1010\end{array}$ & 44 & 10 & 80 \\
\hline 1020 & 44 & 25 & 78 \\
\hline 2000 & 36 & 4 & 85 \\
\hline 2010 & 36 & 11 & 85 \\
\hline 2020 & 36 & 28 & 88 \\
\hline $2020 \mathrm{~L}$ & 36 & 28 & 57.5 \\
\hline
\end{tabular}

\section{日本ゼオン（株）}

ゴム事業部・ゼットポールチーム

西 100 東京都千代田区丸の内 2-6-1（古河総合ビル) 80 03-216-1771

大阪支店

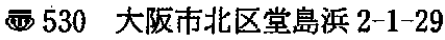

206-343-0721

名古屋支店

恶 460 名古屋市中区錦 1 19-24

- 052-231-8871

岡山営業所

a 700 岡山市丸の内 1-5-22

ธ 0862-31-0201 


\section{グドマー}

\section{高性能オレフィン系熱可塑性エラストマー}

\section{1. 技術の背景と市場動向}

グドマーは, 三井石油化学が長年にわたるプラスチ ックおよび合成ゴムの製造技術, 変性技術, アロイ化 技術を基礎に開発した，高性能オレフィン系熱可塑性 エラストマーである.オレフィン系熱可塑性エラスト マーは, その優れた耐熱性から自動車部品, 土木建 材，工業材料などの多岐にわたる分野で，年及需要が 伸びている.これらの分野では, 成形機の開発と相ま って, 複合成形による製品の高性能化, 並びに製造合 理化が盛んに進められている.

異種材料との親和性, 感熱接着性に優れ, ブレンド 使用や積層成形が可能な, 新しい高性能オレフィン系 熱可塑性エラストマー「グドマー」に, 大きな期待が 寄せられている.

\section{2. 特徵}

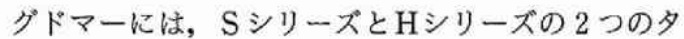
イブがあり, 既存の熱可塑性エラストマーに比較して 次の特徵がある.

（1） Sシリーズは，樹脂・金属・セラミックスとの感 熱接着が容易である.

（2）Hシリーズは，熱線膨張係数が小さく，寸法安定 性に優れている.

（3）耐熱性, 耐候性, 柔軟性, 成形性は, 既存のオレ フィン系熱可塑性エラストマーと同様.

3. 用途

自動車外装材 : 大型バンパー

$$
\text { ソフトフェイシア }
$$

自動車内装材：ドアトリム

$$
\text { インスツルメントパネル }
$$

土木建材 : シート

$$
\text { シール材 }
$$

工業材料 : ホース

$$
\text { チューブ }
$$

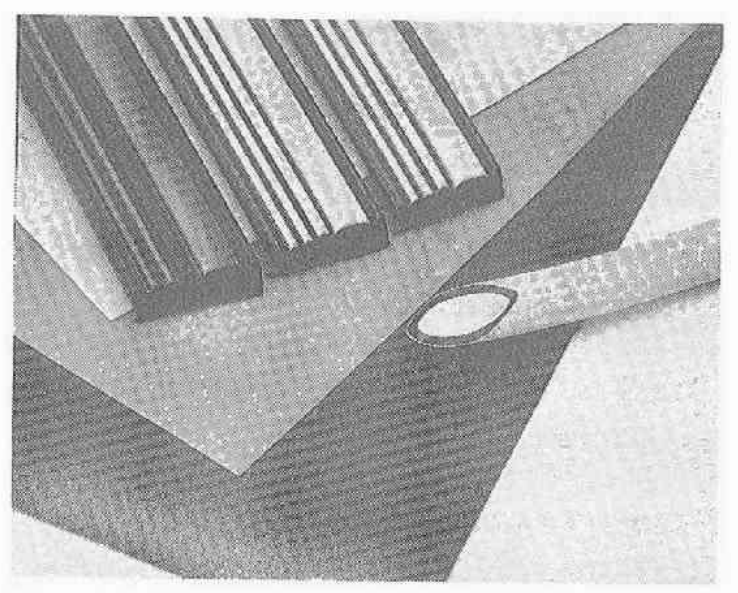

異種材料との感熱接着性 (S シリーズ)

\begin{tabular}{l|c|c}
\hline \multicolumn{1}{c|}{ 異種材料 } & グドマーS シリーズ & 従来品 \\
\hline ナイロン & $>1.5$ & $<0.1$ \\
\hline 鉄 & $>1.5$ & $<0.1$ \\
\hline ガラス & $>1.5$ & $<0.1$ \\
\hline
\end{tabular}

(単位 $: \mathrm{kg} / \mathrm{cm}$ )

寸法安定性 (S シリーズ)

\begin{tabular}{c|c|c}
\hline & グドマー $\mathrm{H}$ シリース & 従来品 \\
\hline $\begin{array}{c}\text { 線膨張係数 } \times 10^{-4} \\
\left(\mathrm{~mm} / \mathrm{mm} /{ }^{\circ} \mathrm{C}\right)\end{array}$ & 0.8 & 1.4 \\
\hline
\end{tabular}

\section{三井石油化学工業（株）}

工業材事業部

本社

国100 東京都千代田区霞が関 3-2-5(霞が関ピル)

జా 03-580-4425 


\section{リベルテ ${ }^{\circledR}$}

\section{消臭・抗菌性繊維}

緎維製品に対するニーズは, 生活を演出するファッ ション性とともに, 快適でより健康的な生活を維持す るための機能性へと高まっている.

帝人はこれに答えて,これまでにさまざまな新瀻維 を開発してきたが, 消臭・抗菌性瀻維「リベルテ®」 もその一つである.「リベルテ®」は従来の “消臭性” のみにとどまらず，有機物を分解して悪臭のもとをつ くる菌類の増殖を阻止する “抗菌性”をも有する高機 能織維である.

\section{1. 技術概要}

「リベルテ®」は帝人の特殊紡系技術を駆使して開 発された 2 種類の瀻維で構成される.

1）片方は，銅微粉末を高濃度に混合したポリプロピ レンを特殊紡糸したもので，“イオウ系悪臭の消 真と抗菌性”を有する。

2）他方は，高濃度カルボキシル基保有ポリマーを鞘 (シース)に, ポリエステルを芯（コア）とした 繊維で, “アミン系悪臭を消臭”する.

\section{「リベルテ ${ }^{\circledR} 」 の$ 擮維構造}

〈イオウ系消臭・抗菌性〉

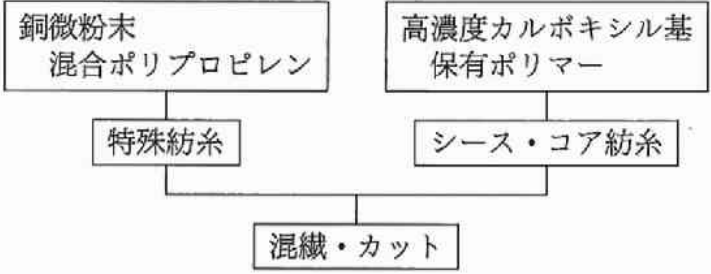

2. 特徵

1）消自性 ・イオウ系，アミン系悪臭を消臭する.

例えば，イオウ系悪臭の硫化水素の場合,「リ ベルテ®」 $1 \mathrm{~g}$ 当りで $36 \mathrm{mg}$ も吸収するが, これ は $1 \mathrm{ppm}$ 濃度の 9 畳間を消臭するのに，わずか 1 $\mathrm{g}$ でよいことに相当する.

また, アミン系悪臭については, 使用後屋外な どで空気中に晒すことで再生できるので, 何度で も繰り返し使用が可能である.

2) 抗菌性 ・ 細菌（黄色ブドウ状球菌, 肺炎桿菌, 大腸菌など）を隇少させる.

・真菌（黒カピ, 青カピ, 白鮮菌など） の成育を阻止する.

3）その他・洗濯や熱処理で効果が落ちない.

・110 $130^{\circ} \mathrm{C} て ゙$ 熱接着できる.

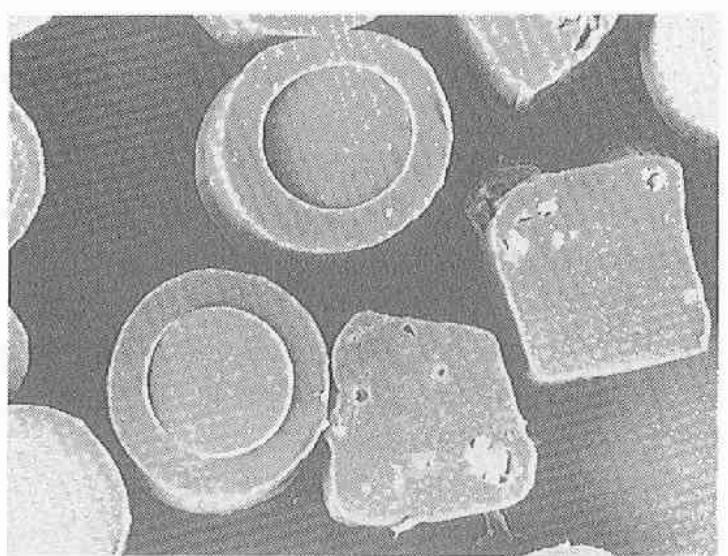

角断面：イオウ系消臭・抗菌性㵶維 丸断面：アミン系消臭緎維

\section{3. 用途}

\begin{tabular}{ll|l}
\hline \multicolumn{1}{c|}{ 分 野 } & \multicolumn{1}{|c}{ 用 } \\
\hline & & \multicolumn{1}{c}{ 途 } \\
\hline 詰 & 老人ホーム用布団, 病院用布団, 業務用 \\
& $\begin{array}{l}\text { 布団, 自動車用クッション, ペット用マッ } \\
\text { トなど }\end{array}$ \\
\hline 不 織 布 & $\begin{array}{l}\text { 台所用シート, 衛生材料, 衣料中綿, レ } \\
\text { ジャー用品, カーペット基布, シートカ } \\
\text { バーなど }\end{array}$ \\
\hline
\end{tabular}

「リペルテ®」は，わた状物や熱接着機能を生かし た不織布として加工され，表のような用途に活用され る.また, 紡績加工が可能であり, 新しい機能性織編 物製品開発への期待が高まっている.

\section{帝人（株）}

東京広報課

東京本社

(100 東京都千代田区内幸町 2-1-1（飯野ビル）

ช 03-506-4055 6

大阪広報課

大阪本社.

(541 大阪市中央区南本町 1-6-7 (帝人ピル)

20 06-268-2761 3 


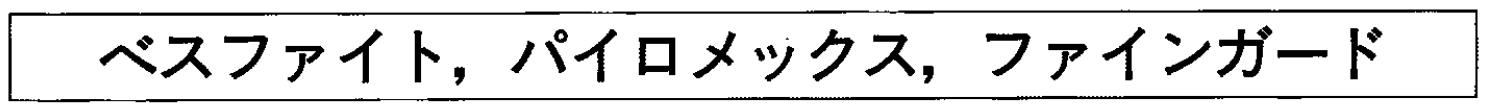

炭素織維およびその関連繊維

\begin{tabular}{|c|c|c|c|c|c|c|c|c|c|c|c|c|}
\hline \multirow[b]{3}{*}{ 特 性 值 } & \multicolumn{12}{|c|}{ ベスファイトの性能 } \\
\hline & & \multicolumn{2}{|c|}{ 高強度 } & 高伸度 & \multicolumn{3}{|c|}{ 中弾性 - 高強度 } & \multicolumn{3}{|c|}{ 高 弾 性 } & \multicolumn{2}{|c|}{ メタルコート } \\
\hline & 单 位 & HTA & HTA & ST-3 & IM-400 & IM-500 & $1 \mathrm{M}-600 \mathrm{X}$ & HM-35 & HMS-40 & HMS-55X & MC-I & MC- II \\
\hline フィラメント数 & 本 & 6000 & 6000 & 6000 & 6000 & 6000 & 12000 & 6000 & 6000 & 12000 & 6000 & 6000 \\
\hline 単辌維直径 & $\mu \mathrm{m}$ & 7 & 7 & 7 & 6.4 & 5.0 & 5.0 & 6.7 & 6.6 & 4.4 & 7.5 & 8 \\
\hline 引張強さ & $\mathrm{kgf} / \mathrm{mm}^{2}$ & 380 & 380. & 440 & 440 & 510 & 590 & 280 & 340 & 386 & 340 & 315 \\
\hline 引張弾性率 & $10^{3} \cdot \mathrm{kgf} / \mathrm{mm}^{2}$ & 24 & 24 & 24 & 30 & 30.5 & 29 & 35 & 40 & 56.9 & 23 & 21 \\
\hline 伸 び & & 1.6 & 1.6 & 1.8 & 1.5 & 1.7 & 2.0 & 0.8 & 0.8 & 0.7 & 1.5 & 1.5 \\
\hline 密 度 & $\mathrm{g} / \mathrm{cm}^{3}$ & 1.77 & 1.77 & 1.77 & 1.75 & 1.76 & 1.82 & 1.79 & 1.84 & 1.93 & 2.7 & 3.4 \\
\hline
\end{tabular}

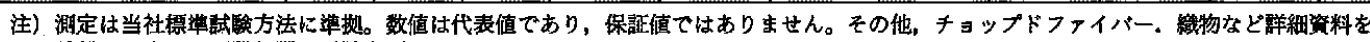

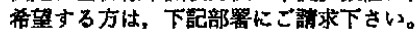

\section{1. 炭慗瀻維 ベスファイト}

東邦レーヨンは, 世界有数の炭索䌜維生産能力（年 産 1,380トン) を持つとともに，米国 CCF 社 (BASF), 西独 AKZO 社に技術を供与し, 日・米・欧 の協力体制の下に，世界市場において強力な販売を展 開しています

ハイグレード化するベスファイトは，スポーツ・レ ジャ一用品から各種産業用途, 航空宇宙用途にいたる 応い分野で使用され，その優れた性能が認められてい ます。

\section{2. 耐炎瀻維 パイロメックス}

パイロメックス®は在来の有機㵶維の中で最も優れ た耐炎性をもっている．耐炎性を評価する方法として 一般に採用されている LOI 值は50〜60の範囲にあ り，他䄉維と比較して抜群に高い。

\begin{tabular}{l|c|c|c}
\hline & 単位 & パイロメッス & アスベスト \\
\hline 值 径 & $\mu \mathrm{m}$ & $13 \sim 15$ & $\sim 0.1 \sim$ \\
引偓強さ & $\mathrm{g} / \mathrm{d}$ & $1.8 \sim 2.6$ & $10 \sim 24$ \\
伸 び & $\%$ & $10 \sim 16$ & $3 \sim 3.5$ \\
密 度 & $\mathrm{g} / \mathrm{cm}^{3}$ & $1.35 \sim 1.45$ & $2.4 \sim 2.6$ \\
水分(RH65\%) & $\%$ & $6 \sim 10$ & 2.3 \\
比抵抗 & $\Omega \cdot \mathrm{cm}$ & $10^{10} \sim 10^{12}$ & $(\mathrm{RH} 85 \%)$ \\
\hline
\end{tabular}

\section{3. 活性炭类緎維 ファインガード}

ファインガードは特異な吸着性を示す活性化された 炭素繊維である。

代表的吸着特性

・吸着・脱着速度が速い,

・低濃度ガスに対してもよく吸着する。

・イオウ化合物，オゾン，塩素などに対し，良好な 吸着 (分解) 特性を示す.

\begin{tabular}{l|c}
\hline 比表面稓 & $500 \sim 1200 \mathrm{~m}^{2} / \mathrm{g}$ \\
平均細孔直径 & $20 \sim 40 \AA$ \\
織維直径 & $7 \sim 15 \mu \mathrm{m}$ \\
織維引張強度 & $20 \sim 50 \mathrm{~kg} / \mathrm{mm}^{2}$ \\
$\mathrm{~N}$ 含有量 & $2 \sim 10 \%$ \\
外表面穔 & $0.2 \sim 0.7 \mathrm{~m}^{2} / \mathrm{g}$ \\
ベンザン平衡吸着量 & $20 \sim 50 \%$ \\
\hline
\end{tabular}

\section{東邦レーヨン（株）}

ベスファイト：803-278-7664 (山本)

パイロメックス： 203-278-7665 (長谷部)

ファインガード：⓪3-278-7667 (荒井)

303 東京都中央区日本榻 3-3-9 


\section{ダイニーマ SK60}

\section{超高強力ポリエチレン緎維}

ダイニーマSK60 讨, 東洋紡績（株）とオランダの DSM 社が共同で開発した超高強力ポりエチレン織維 である。本瀻維は，「ゲル紡糸法」と㭔ばれるニュー テクノロジーにより生み出されたスーパー織維であり 数々の優れた特性を有している。

\section{1. 基本的性能}

「ゲル紡系法」の概念とダイニーマSK60 の構造を 模式的に示すと図1のようになる。

図にみられるように非常に高い分子配向性と結晶性 を有するダイニーマSK60 は, (1)比強度・比弾性率が 既存のどの織維よりもバランス良く高い（図 2)。 た，(2)比重が1以下と軽量であることも大きな特長で ある。その他に，(3)耐衝倝性，(4)耐菒品性・耐候性， (5)票摩耗性·䃌疲労性，(6)水分率=0\%，(7)振動減衰性 などに優れるという特長を持つ。

\section{2. 用途}

軽量かつ高強力，しかも水分率 $=0 \%$ のダイニーマ は，ロープ・コード分野，特に海洋分野でのロープ・ 釣系などで魅力的な素材である，また，本緎維の後加 工性の良さを利用して作られたファブリックは，セ一 ルクロス・フィルター・ジオテキスタイルなどの分野 で利用できる。

ダイニーマ SK60 の軽量・高強力・振動減衰性・昅 湿しない，さらには耐衝擊性に優れるといった特性 は，コンポジット用補強材としても威力を発揮する. 特に，音の伝播特性の良さを利用してのスピーカーコ ーン用素材が注目を集めている，また，他のヘルメッ ト・スポーツ用品などの用途も考えられる。

その他の用途例として, 光ファイバーの抗張力材 防護手袋などの防蒦材・压力容器・アーチェリーの弦 などのユニークなものがあげられる。

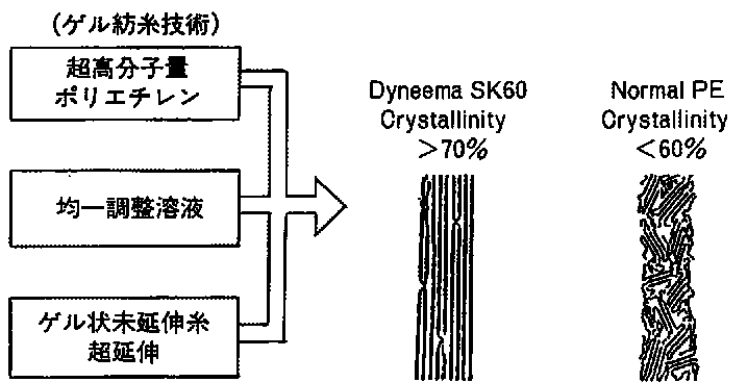

図 1 ゲル紡系法とダイニーマ SK60 の構造の概念図

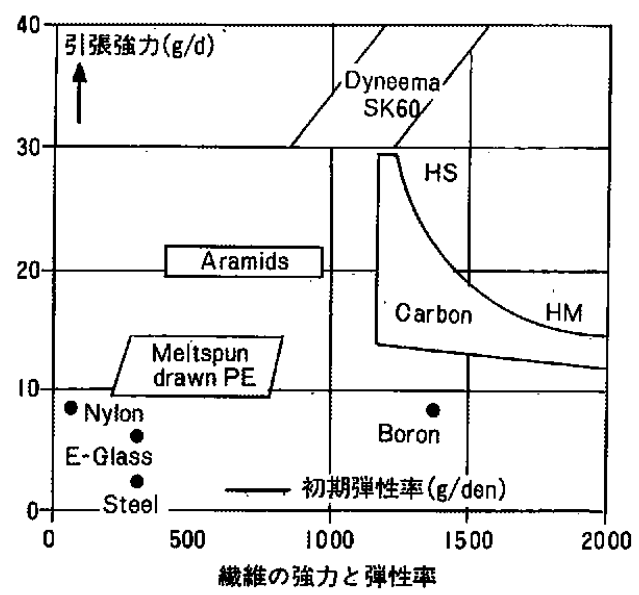

图 2 各種緎維の強度と弾性率

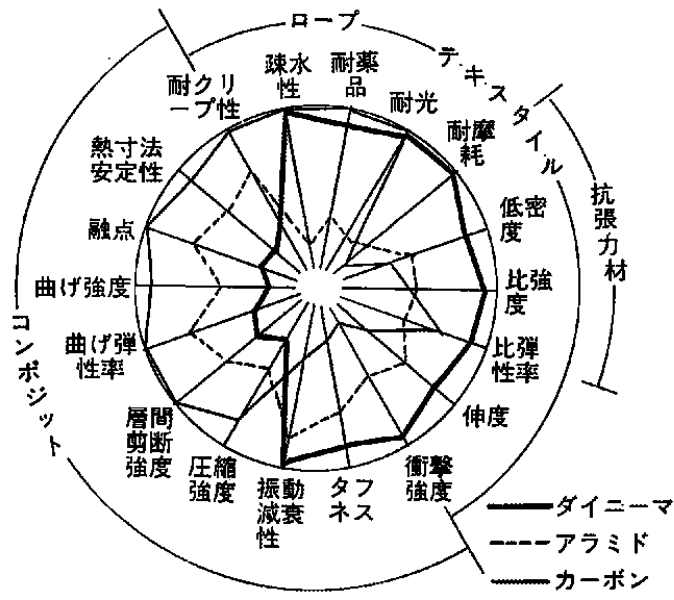

图 3 各種高強力織維の特性と各用途における要求品留 (外周に向かうほと好ましい)

\section{3. 今後の展望}

ダイニーマ SK60 の優れた特徵を生かした新用途が 開発される一方で，ポリエチレンであるゅえの弱点と しての接着性・耐熱性などは, 今後改善されていくと 考えられる。

\section{東洋紡績 (株) \\ ダイニーマ・ジャパン社}

E5 530 大阪市北区堂島 2-2-3

क 06-348-3445 


\section{テクミロン ${ }^{\circledR}$}

\section{超高強度ポリエチレン繊維}

超高強度ポリエチレン繊維とは，直鎖状ポリエチレ ン繊維の分子構造を高次制御することによって得られ る, 極めて強度, 弾性率に優れた織維である.この点 では従来最も優れていた, 芳香族ポリアミド（アラミ

ド）織維をも上回る性能を持っている.

製造方法としては, 工業化の可能な方法として現在 「ダル紡糸法」および「溶融延伸配向法」と呼ばれる, 二つの方法が紹介されている. 前者が, 低濃度のポリ マー溶液からポリエチレン分子鎖同士のからみ合いの 少ないゲル状繊維を紡系するのに対し, 後者は流動性 付与剤の効果を利用し, 分子構造を制御しながら配向 纎維を紡糸するものである.

超高強度ポリエチレン繊維の特長は, 前述の強度, 弾性率に優れる点の他，ポリエチレンが本来持つ耐水 性, 而酸・アルカリ性, 而候（光）性, 而寒性の優れ た特性も保持している. 反面，ポリエチレンの弱点で ある耐熱性，耐クリープ性には劣るとされてきた。

三井石油化学では, これらの弱点を改善した, いわ ゆる第二世代の超高強度ポリエチレン瀻維 “テクミロ ン®”の開発に成功した.

\section{1. 物性}

(1) テクミロン耐熱銘柄 “テクミロン-HR”

テクミロン-HR は耐熱性が大幅に改善されてお り, 絨維を固定した状態での加熱加工では, 短最時 間ではあるが $200^{\circ} \mathrm{C} に も$ 耐えることができる.

〈基本物性〉

銘柄名 : HA $310(1,000 \mathrm{~d} / 100 \mathrm{f})$

引張強度 : $2.2 \mathrm{GPa}(24 \mathrm{~g} / \mathrm{d})$

弾性率 $: 60 \mathrm{GPa} \quad(700 \mathrm{~g} / \mathrm{d})$

破断伸び： $5.0 \%$

〈耐熱性〉

図 1 に示す.

(2) テクミロン耐クリープ銘柄 “テクミロン KR”

テクミロン KR はクリープ特性が大幅に改善さ れており，芳香族ポリアミド繊維に匹敵するほどの 低いクリープ特性を示す.

〈基本物性〉

銘柄名 : KA $310(1,000 \mathrm{~d} / 100 \mathrm{f})$

引張強度 : $2.0 \mathrm{GPa}(22 \mathrm{~g} / \mathrm{d})$

弾性率 : $55 \mathrm{GPa} \quad(600 \mathrm{~g} / \mathrm{d})$

破断伸び: $5.0 \%$

〈クリープ特性〉

図 2 に示す.

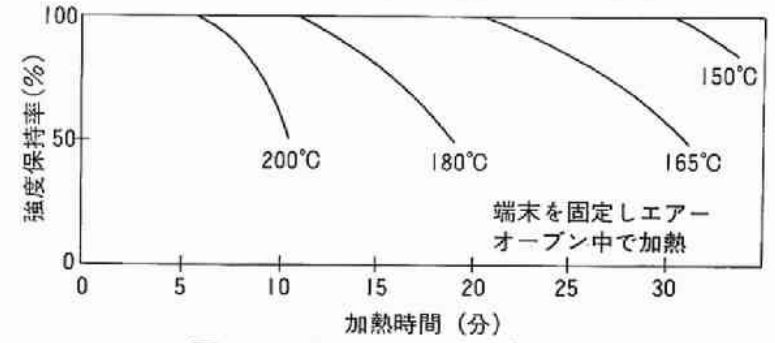

図 1 テクミロン-HR の耐熱性

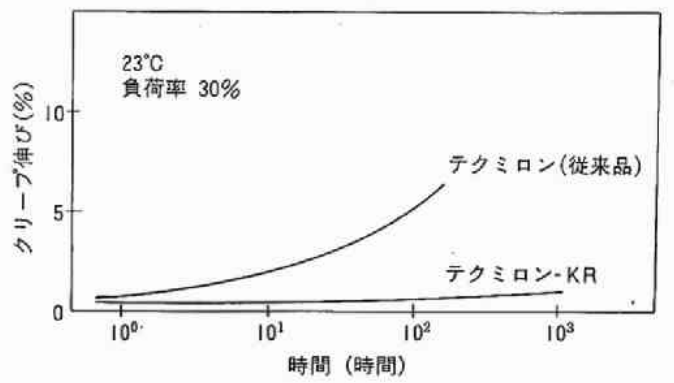

図 2 テクミロン-KR のクリープ特性

2. 用途

○単材：ロープ・ひも類（海洋ロープ・釣糸など）, 織布・不織布類（防弾チョッキ・帆布など）, 電気ケーブル, その他

○複合材料：スポーツ用品(各種ラケットなど), レ ジャー用品(ヨット、サーフィンボー ド), 音響材料 (スピーカー), その他

\section{三井石油化学工業 (株)}

\section{新素材開発部}

本社

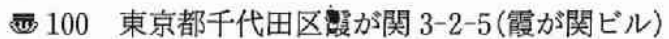

รా 03-593-2248 


\section{東セロ “TAF-502, TPX, ADF”}

\section{多層 PP フィルム, 特殊ポリマーフィルム}

\section{1. 技術の背景}

食品包装用フレキシブルフィルムから産業用特殊フ イルムまで，永年蓄積された当社のキャストフィルム 製造技術と高性能の共押出多層フィルム生産設備を駆 使して,これまでに多数の CPP フィルム, 特殊多層 フィルム “TAF”, 特殊ポリマーフィルムなどを開発 し，市場に供給してきました。

このたび新たに，M社製の最新鋭の多層フィルム設 備を設置し, 三井石油化学特殊ポリマー事業部の協力 を得て, 超高速自動包装用フィルム“TAF-502” 開発するとともに, エポキシ樹脂硬化用特殊離形フィ ルム・TPX, 鋼板ラミネート用特殊接着フィルム ADF を完成することができました。

\section{2. 特徵と応用}

TAF-502〈東セロ多層 PP フィルム〉

多層構造の表層に, 特異な結晶形挙動を示す立体規 則性高分子量ポリマーを導入した無延伸多層特殊フィ ルムで, ポリプロピレン系フィルムの特徵とともに超 低温ヒートシール性を兼備したフィルムである。

（1）一般 PP より， $40^{\circ} \mathrm{C}$ 低い超低温 HS 性.

（2） PP フィルムと同水準の透明性, 機械強度.

(3) OPP フィルムのシーラント層として最適.

（4）高速自動包装用シーラントとして，50\% 以上の 生産性向上を期待しうる。

TPX〈特殊ポリマーフィルム〉

プロピレン二量体を重合した4-メチルペンテンポ リマーをキャスト形成したフィルムで，ポリオレフィ ン樹脂の中では最も高い融点 $\left(235^{\circ} \mathrm{C}\right)$ を示し, 耐熱 変形性が優れた特殊フィルムである。

（1）透明性がよい一光線透過率 $90 \%$ 以上

（2）エポキシ樹脂に対する離型性がよい (表面張力 24 dyne $/ \mathrm{cm}$ )

（3） $200^{\circ} \mathrm{C}$ における寸法変化が少い（2\% 以下）

（4）電気絶縁性（耐電圧 $65 \mathrm{KV} / \mathrm{mm}, \varepsilon 2.12$ )

（5）耐油性，耐酸・耐アルカリ性，耐水・耐薬品性）

これらの性質から電子材料成形や食品工業用途にお ける高温離形フィルム, 電力ケーブル用絶縁フィル ム，その他種々の応用が期待されます．

$\mathrm{ADF}$ 〈アドマーフィルム〉

アドマーフィルムは, 三井石油化学工業 (株) と当 社が独自の技術で開発した熱接着性高分子フィルム で, 各種基材に強固に接着する機能性ポリオレフィン フィルムである，ポリオレフィン樹脂に特殊な官能基

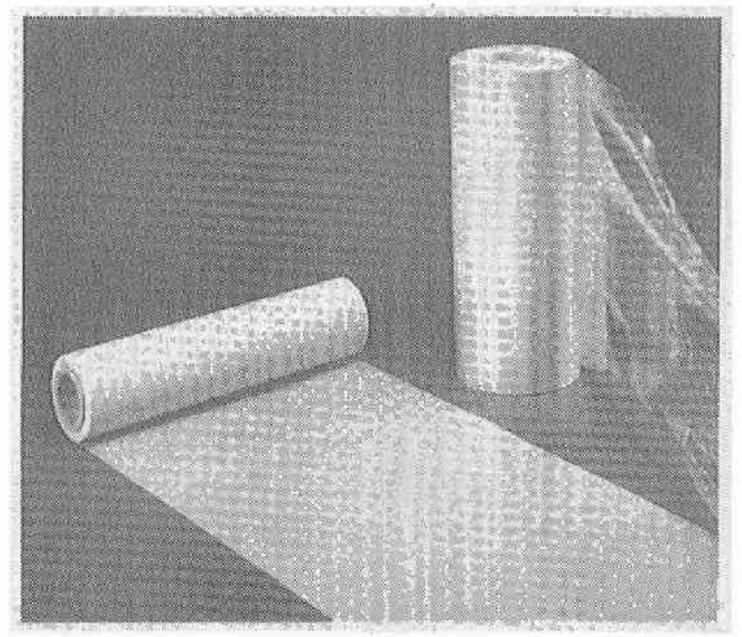

を導入し改質したポリマーフィルムで，ポリオレフィ ン樹脂の優れた性質を完全に保持したまま熱接着性フ イルムとして機能します

（1） アルミ䇴，鋼板などの金属接着用途

（2）工業薬品用金属容器ラミネート用途

（3）布，織物，不織布用乾式接着用途

（4）家具, 家電, 自動車内装など接着用途

$\mathrm{ADF}$ フィルムには, PP 系, PE 系, EVA 系の 3 種 があり, 被着材の種類, 接着条件に応じて選択できる よう用意されています。

\section{東セ口化学（株）}

開発部，技術部

本社

③06 茨城県猿島郡総和町丘里 3

\& 0280-98-1115 FAX 0280-98-3084

注) TPX フィルムの販売悹口は三井石油化学工業·特殊 ポリマー事業部(ð003-593-1630)となっています. 


\section{ルピック (LUPIC)}

\section{高密度ポリエチレン二軸延伸フィルム}

搞密度ポリエチレン（HDPE）は非常に古い歴史を もつ樹脂でありながら，結晶性の䒽い特有の結晶構造 をもつため, 二軸延伸加工は極めて難しいものとされ ていました。

HDPE をポリプロピレン (PP) や, ポリエステル (PET) などと同様な方法で二軸延伸を行っても延伸 中に破膜し，また，たとえ延伸できたとしても均一延 伸が難しく，高透明で均質なフィルムを得ることは困 難であり.ました。

当社は二軸延伸のために特別に開発した樹脂と独自 の製膜法によって世界で初めて HDPE 二軸延伸フィ ルム「ルピック」の開発に成功いたしました。

「ルピック」は，縦・横ともバランスのとれた強度 と，強靶性をもち，また画期的な機能性および自在な 加工適性を併せもっています。

また原料樹脂の分子設計とフィルムの製造条件をコ ントロールすることにより，「ルピック」の特有の機 能を強調した多様な銘柄をつくることができます.

「ルピック|の主な特賑は以下のとおりです。

○啜蒿の耐折り曲げピンホール性

(耐フレキソクラック性)

○優れた防湿性能

○優れた折り曲げ適性（デッドフォールド性）

(折り目をつけることができる性質)

○画期的な表面平滑性

○優れた離型性

$O \gamma$ 線殺菌しても劣化せず無臭

○倀れた耐衝慗強度（特に低温衝撃）

○高透明・高光沢

○優れた縦・横の強度・剛性バランス

○䤠のない直線カット性

○セロファンによく似た感触

このような特性から，「ルピック】は次のような用 途展開が可能です。

(1)軟包装で従来の包装は，包材全体の強度と機能

およびシール性を出すために，異なったフィル ムを何層も重ねることが多かったが,「ルピッ ク」の使用で多くの機能性が付与される上に尿 構成が簡略化できます。

(2)ブローボトル用のラベルへの応用ができます。 素材がボトルと同じ HDPE で, 透明で调性の ある厚手のフィルムシートができることから，

一体感，喬級感のあるラベルをつくることがで
LUPIC の標準物性

\begin{tabular}{|c|c|c|c|c|c|}
\hline \multirow{2}{*}{$\begin{array}{l}\text { フィルム銘柄 } \\
\text { 公称原み } \mu \mathrm{m}\end{array}$} & \multicolumn{3}{|c|}{ LUPIC-H } & \multirow{2}{*}{$\frac{V}{15}$} & \multirow{2}{*}{$\frac{\mathrm{K}}{15}$} \\
\hline & 15 & 20 & 25 & & \\
\hline $\begin{array}{ccc}\text { 透 } & \text { 明 } \\
(\%) & \text { 度 }\end{array}$ & 2.5 & 3.0 & 3.8 & & 4.0 \\
\hline 光 $\begin{array}{c}\text { 沢 度 } \\
(\%)\end{array}$ & 150 & 145 & 140 & & 140 \\
\hline $\begin{array}{c}\text { 引㲀破断強度 } \\
{[\mathrm{MD} / \mathrm{TD}} \\
\left(\mathrm{kg} / \mathrm{mm}^{2}\right)\end{array}$ & $15 / 18$ & $16 / 18$ & $16 / 17$ & $15 / 18$ & $15 / 18$ \\
\hline $\begin{array}{l}\text { 引張破断伸度 } \\
{[\mathrm{MD} / \mathrm{TD} \text { (\%) }}\end{array}$ & $80 / 60$ & $80 / 60$ & $85 / 63$ & $80 / 60$ & $80 / 60$ \\
\hline $\begin{array}{c}1 \% \text { 引張弾性率 } \\
(\mathrm{MD} / \mathrm{TD}] \\
\left(\mathrm{kg} / \mathrm{mm}^{2}\right)\end{array}$ & $230 / 275$ & $250 / 290$ & $250 / 290$ & $230 / 275$ & $210 / 250$ \\
\hline $\begin{array}{c}\text { 打抜衛擊強度 } \\
\mathrm{kg} \cdot \mathrm{cm}\end{array}$ & 7.5 & 9 & 11 & 7.5 & 7.5 \\
\hline 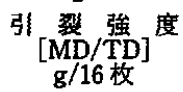 & $4 / 3$ & $8 / 6$ & $11 / 8$ & $4 / 3$ & $4 / 3$ \\
\hline $\begin{array}{c}\text { 水蒸気透過率 } \\
\mathrm{g} / \mathrm{m}^{2} \bullet \\
24 \mathrm{Hr}\left(40^{\circ} \mathrm{C}\right)\end{array}$ & 5 & 3.5 & 2.8 & 0.2 & 2.2 \\
\hline $\begin{array}{c}\text { 酸率過率 } \\
\text { c.c. } / \mathrm{m}^{2} \cdot \\
24 \mathrm{Hr}\left(30^{\circ} \mathrm{C}\right)\end{array}$ & 2,000 & 1,500 & 1,250 & & 6 \\
\hline
\end{tabular}

きます

(3)「ルピック」のデッドフォールド性（折り目が つく性筫や耐ピンホール性，防湿性を生かして 特に紙やアルミ䇴とラミネートする用途に向い ています。

(4)光沢の良さや強度, デッドフォールド性を生か したひねり包装への用途にも適しています。

「ルピック」の開発は 1981 年にスタート．特許も基 本特許，応用特篦，海外特許，併せて 30 件以上を出 願しています。

1988 年に川崎市の千悬工場内に，年産 300 トンの パイロットラインが完成し，現在サンプルを用いて市 場開発を進めています

本格的な商業規模での生産は1990年に予定してお り，現在の千鳥工場内に年産約 4,000トン規模のプラ ントを予定しています 既にテスト販売を開始してお り内外のユーザーに採用され始めています。

\section{東燃石油化学（株）}

ルピック営業部

s 104 東京都中央区築地 4-I-1（東劇ビル）

¿ 03-5565-0952 FAX 03-5565-1654 


\section{東レアラミドフィルム}

\section{パラ系芳香族ポリアミドフィルム}

\section{1. 技術的背尞}

アラミド (パラ系芳香族ポリアミド)・フィルムの実 現には，(1)製造自体が困難（異方性ドープの問題）, (2)湿度特性が悪い，という問題が存在していた，これ らの障害を克服したのが，東レが開発したアラミドフ イルム「TX-I]で, 高剛性・耐熱・薄葉フィルムとい う新しはカテゴリーに属する高機能フィルムである.

\section{TX-I の特徵}

\section{（1）機械的特性}

パラ系アラミドフ・イルムの最大の特長は機械特性で あり, 破断強度はポリイミドの 2.5 倍, PET の 2 倍, 弾性率は PET の 3 倍と工業フィルム中最高である. したがって，薄いフィルムでも腰の強さ（スティフネ ス）が大きいために，厚い他のフィルムと同様の取扱 いが可能である. 現在 $1.5 \mu \mathrm{m}$ の厚さまで製造でき る.

（2）熱的特性

耐熟性と寸法安定性（耐ハンダ性など）はポリイミ ドに次ざ，融点，ガラス転移点が存在しないため瞬間 的には $300^{\circ} \mathrm{C}$ 以上の使用も可能である，長期耐熱性は $180^{\circ} \mathrm{C}$ 以上（現在 UL $746 \mathrm{~B} 160^{\circ} \mathrm{C}$ 暫定認定取得. 試験 継続中), 燃焼性は自己消火性 (UL94 V-O 取得) で, $6 \mu \mathrm{m}$ 以上と非常に薄い範囲から耐熱用途で使用でき る.

熱膨張係数は $0.8 \times 10^{-5}\left(1 /{ }^{\circ} \mathrm{C}\right)$ から $2.5 \times 10^{-5}$ $\left(1 /{ }^{\circ} \mathrm{C}\right)$ まで調整可能で，銅䇴などと積層してもカー ルの問題は生じないフィルム設計ができる。

(3) 化学的特性

従来のアラミドの吸湿率, 湿度膨張が大きいという 欠点はフィルムにとって致命的であるが，TX-I では 特異的に，これを実用レベルにまで低下させることに 成功した。

酎薬品性は良好で, 汎用有機溶剤, 酸, アルカリに は十分耐える．また高温高湿度下でも加水分解しない 点はポリイミドやPET にない特長である。

（4）その他の特性

(1)表面超平滑化が可能（表面粗度 $0.002 \mu \mathrm{m}$ 以下）, (2)接着性が良好, (3)印刷適性が良好, (4)加熱成形加工 が可能（例党ば振動板）などの特性は実用段階では重 要な特性だど考えられる。

\section{3. 用途}

TX-I はその特性から,フィルムが薄いことによっ て付加価值を生じる用途，さらに耐熱性，難燃性が必

\begin{tabular}{|c|c|c|c|c|}
\hline \multicolumn{2}{|r|}{ 項 目(単位) } & TX-I & ポリイミド & PET \\
\hline \multicolumn{2}{|r|}{ 密 度 $\left(\mathrm{g} / \mathrm{cm}^{3}\right)$} & 1.50 & 1.42 & 1.40 \\
\hline $\begin{array}{l}\text { 機 } \\
\text { 械 }\end{array}$ & $\begin{array}{l}\text { 破断強度 }\left(\mathrm{kg} / \mathrm{mm}^{2}\right) \\
\text { 破断伸度 }(\%)^{\circ} \\
\text { 引張弾性率 } \\
\left(\mathrm{kg} / \mathrm{mm}^{2}\right)\end{array}$ & $\begin{array}{r}50 \\
60 \\
1,300\end{array}$ & $\begin{array}{r}18 \\
70 \\
300\end{array}$ & $\begin{array}{r}25 \\
130 \\
400\end{array}$ \\
\hline 熱 & 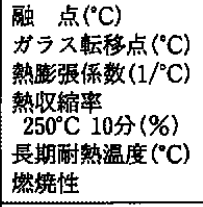 & $\begin{array}{c}\text { なし } \\
\text { なし } \\
2.0 \times 10^{-5} \\
0.7 \\
180 \\
\text { 自己消火性 }\end{array}$ & $\begin{array}{c}\text { なし } \\
\text { なし } \\
2.5 \times 10^{-3} \\
0.3 \\
210 \\
\text { 自己消火性 } \\
\end{array}$ & $\begin{array}{r}263 \\
69 \\
1.7 \times 10^{-5} \\
- \\
120 \\
\text { 徐々に燃焼 } \\
\end{array}$ \\
\hline $\begin{array}{l}\text { 化 } \\
\text { 学 }\end{array}$ & 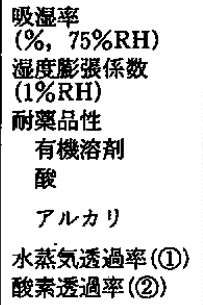 & $\begin{array}{c}1.5 \\
1.0 \times 10^{-5} \\
\text { 依 } \\
\text { 強酸に疆い } \\
\text { 優 } \\
0.22 \\
0.15\end{array}$ & 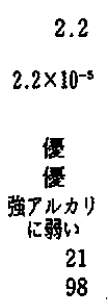 & $\begin{array}{c}0.4 \\
1.2 \times 10^{-3} \\
\text { 传 } \\
\text { 優 } \\
\text { 優 } \\
6.9 \\
19\end{array}$ \\
\hline $\begin{array}{l}\text { 殗 } \\
\text { 気 }\end{array}$ & $\begin{array}{l}\text { 絶縁破断電圧 } \\
(\mathrm{KV} / \mathrm{mm}) \\
\text { 誘電率 } \\
(-, 1 \mathrm{KHz}) \\
\text { 誘電正接 } \\
(\%, 1 \mathrm{KHz})\end{array}$ & $\begin{array}{l}4.2 \\
2.5\end{array}$ & $\begin{array}{l}3.5 \\
0.3\end{array}$ & $\begin{array}{l}310 \\
3.3 \\
0.2\end{array}$ \\
\hline
\end{tabular}

(1): $\left(\mathrm{g} / \mathrm{m}^{2} / 24 \mathrm{hr} / 0.1 \mathrm{~mm}\right)$

(2): $\left(\mathrm{cc} / \mathrm{m}^{2} / 24 \mathrm{hr} / 0.1 \mathrm{~mm} / \mathrm{atm}\right)$

要な用途に適している.

磁気テープの分野では，フィルムの薄葉化がカセッ トの小型化, 長時間化を可能にする。.また今後実用化 される蒸着型磁気記録媒体ではフィルムの耐熱性によ って磁性層の特性向上を容易に達成できると考えられ る.

界華型感熱転写では，フィルムが薄く非溶融である ことにより高速・高濃度のプリントが可能となる.

耐熱フィルムの代表的用途として FPC があるが， TX-I はポリイミドと同様の加工, 使用が行え，加え て印刷特性,成形性を生かして従来にない形態の FPC の実現も期待できる。

以上の代表例以外にも，これまで薄い耐熱フィルム が存在しなかったがゆえにフィルムが使用されなかっ た用途も数多く存在するものと考えられ，それらの分 野での展開が期待される.

\section{東レ（株）}

ルミラー第 1 事業部工業材料販売課

巴5 103 東京都中央区日本橋室町 2-2

8 03-245-5427 FAX 03-245-5523 


\section{トレリナ}

2 軸延伸ポリフェニレンサルファイドフィルム

\section{1. 技術の背罢}

“トレリナ”は東レ(株)が新しく開発した高結晶性, $\mathrm{F}$ 種耐熱性高性能フィルムで, 東レの得意とする高分 子技術, 製膜技術を駆使し,また PPS の産みの親であ る米国 Phillips Petroleum 社とも提携しつつ，2 軸延 伸 PPS フィルムの開発を行った結果, 1982 年初めよ り,このフィルムの商業生産を開始するに至りました.

\section{2. “トレリナ" の特長}

“トレリナ”の主要な特性を，他のフィルムと比較 して，表に示します。

（1）製法おるび性状 “トレリナ”は，約 $40 \%$ の結 晶化度を有する結晶性の 2 軸配向フィルムです.

（2）機械特性および厚み ポリエステルフィルムに 匹敵する機械特性を示し, 単体で最大 $125 \mu \mathrm{m}$ の厚み のフィルムが提供できます。また, $2 \mu \mathrm{m}$ 以下のごく 薄いフィルムの製造も可能です。

（3）耐熱性・耐寒性 UL746B 規格の長期酎熱温度 インデックスは, 機械物性で $160^{\circ} \mathrm{C}$, 電気物性で $180^{\circ} \mathrm{C}$ に及び,極めて高い温度における連続使用が可能です。

（4）吸湿特性抒よび耐加水分解性 吸湿率, 吸湿膨 張係数のいずれもポリエステルフィルムに比べて一桁 低い值を示しており, 湿度変化に対する諸物性の変化 がほとんどありません，また，高温の水蒸気中で劣化 が加速されるという欠点もありません。

（5）難燃性 自己消火性を有しており，25 $\mu \mathrm{m}$ 以 上の厚みにおいては，UL94 規格の V-0 グレードに 認定されています，また，これより薄いものも，本質 的には同じ性質を有しています。

（6）耐薬品性 ほとんどすべての化学薬品に対して 抜群の耐久性を有して扔り，特に，このフィルムを常 温で溶解する溶媒は見いだされていません，酸，塩基 に対しても極めて安定です。

（7）耐放射線性 $\gamma$ 線, 中性子線などの放射線に対 して優れた耐久性を有しております。

（8）電気特性 誘電率の温度および周波数依存性が 小さく，また極めて低い誘電損失を，より高温まで維 持しています。

\section{3. “トレリナ” の用途}

PPS フィルムの最大の特長は各種特性のバランス の良さにあります，そのために，用途分野はモー夕 一,トランスなどの F 種耐熱電気絶縁材料としての応 用にとどまらず, コンデンサー, 回路基板, 粘着テー プ，自動車・電子部品など多岐にわたっています。
表 1

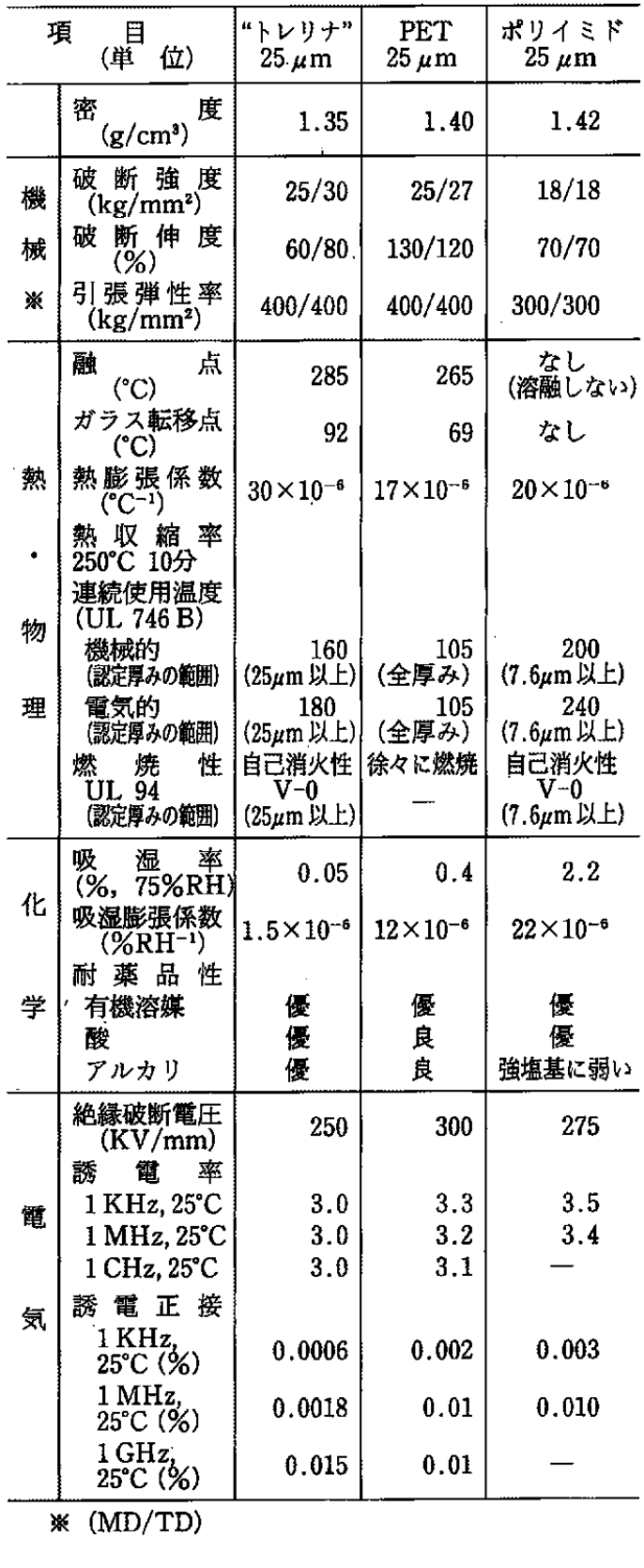

東レ（株）

ルミラー第 1 事業部工業材料販売課

心103 東京都中央区日本橋室町 2-2

¿03-245-5427 FAX 03-245-5523 


\section{特殊機能加工品シリーズ}

\section{無機質充塤ポリオレフィン系フィルムおよびシート}

\section{1. 技術の背墨と市場動向}

日産丸善ポリエチレンは，長年のコンパウンド技術 と成形加工技術を駆使して，一連の “特殊機能加工品 シリーズ”を開発した. それそれの機能を持った充填 剤を特殊ポリオレフィン樹脂に均一に分散させて成形 したのち, 種々の加工工程を経て得られる.

これらは適度な透気性, 透湿性を有したり, 酸素を 吸取したり，吸湿や脱臭の性質を持つなどの特徴があ る.

わが国では，消墨生活の多様化が進み，包装，衣 料，建築などの分野て用いられる材料はますます高機 能化，高性能化して，種々の使用目的や新規なデザイ ンに調和する性筫が要求されるようになった，当社の “特殊機能加工品シリーズ”はこれらのニーズに対し, きめ細かく対応するべく開発された。

\section{2. 特徽と用途}

(1) 透湿性フィルム

ポリオレフィンに無機質充潩剤を配合し，特殊な加 工を経て得られたもので，数 $\mu \mathrm{m}$ 以下の微細な孔を 有している，連通孔のため，空気，水蒸気などは通す が，水は通さないという特徵がある。空気通過量は用 途に対応して適切な調節も可能である。柎水性があ り，引裂強度のタテ，ヨコのバランスが良好でしなや かな風合いを持つ. また, ホットメルト適性, シール 適性が十分であり二次加工性に優れている，製品とし ては,フィルム単品型と不織布などと貼り合わせた積 層型がある。

蒸れない, 漏れないという特徵を生かして, 紙おむ つ・生理用品の防水シート，手術衣，敷布などの医療 用品, 防水衣料, 脱酸素㓮・乾燥剤などの包装フィル ム, 壁紙, 結露防止用フィルムなどへの応用が考えら れる.

(2) 脱酸素フィルム

ポリオレフィンに金属粉を均一に分散させたのち, 特殊な積層工程を経て得られる。充填刜との反応によ りフィルム，シートは，周囲の酸素を吸収できる。

食品, 医薬品などは貯蔵中に酸素により酸化されて 変質したり, カビ, 好気性細菌の増殖により品質劣化 したりするが，この包荘材料を用いることによって酸 素のない環境となり，これらの問題は解決される.

任意の大きさ, 形状に切り出し, 酸素遮断性の密閉 容器内に挿入したりこの材料を賦形して容器を作 り, 容器自体に脱酸素性能を持たせるなどの使用法が

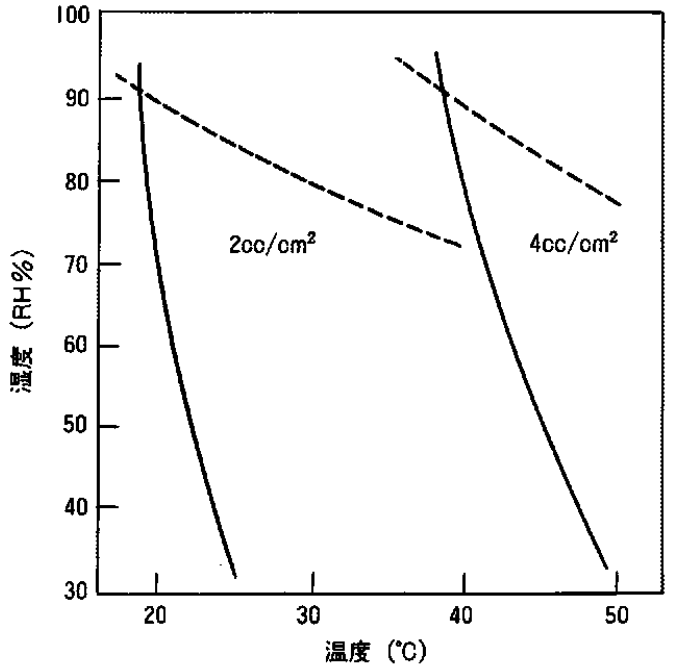

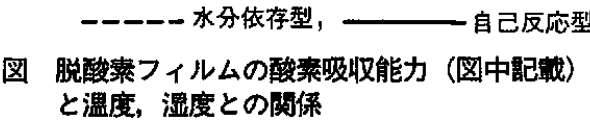

ある，さらに他の材料との貼り合わせ，組み合わせや 印刷を施すことにより種々の新しい包装システムに応 用できる，高湿度下で用いられる水分依存型と乾燥状 態でも用いられる自己反応型の 2 種類のグレードがあ る. 食品, 医薬品の包装の他, 精密機器, 電子機器の 包装，高級衣料品の保存などの用途が考えられる.

（3）脱湿フィルム抢よび脱茼シート

ポリオンフィンに水分を反応吸着できる充填剤を配 合した脱湿フィルム，鼻気成分を吸着できる特殊活性

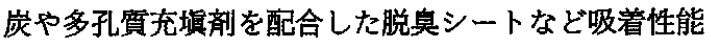
を特街とするシリーズである。

脱臬シートに㹥気成分がシート基質内に十分に拡 散し, 充填剤と反応できるように微細な連通構造を有 している，包装袋や挿入用シートなど多目的に使用可 能である。

\section{日産丸善ポリエチレン（株）}

301 東京都千代田区神田錦町 3-7-1

Z7 03-296-8326 FAX 03-296-8366 


\section{ハイレトフレックス}

「ハイレトフレックス」は, ファッショナプルなプ ラスチック外锶を有しながら気体, 水蒸気, 光を完全 に遮断し, 食品を 2 年間の長期にわたり保存すること ができるハイテク時代の新しいカップ状容器である (写真 1).

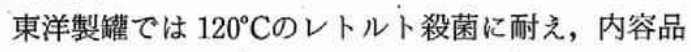
を長期保存できるレトルトパウチ「RP-F」を開発し, 新しい包装食品の分野を築いてきたが，このパウチで 用いられている高度のラミネート技術に加えて, 新た に開発された高性能スチール䇴を基材とした新積層材 料，およびこれを成形するために独自に開発した特殊 成形技術によって実現したのがハイレトフレックスで ある。

\section{1. 材料構成}

図 1 にハイレトフレックスの材料構成を示す. 中間 層の $75 \mu \mathrm{m}$ スチール箔は優れた成形性を示し, 特殊 表面処理により耐食性や接着性が向上されている.

内外面層には, ファッショナブルな外観を表現する ためチタンホワイトを充填したポリプロピレン (CPP) フィルムが用いられている. 内面 CPP は直接 食品と接触するためにフレーバー特性のよいグレード が選定されている，また各層の接着には，成形が高温 でのレトルト殺菌に耐えるような耐熱性接着剤が用い られており, 高い初期接着強度が得られている.

\section{2. ハイレトフレックスの特徵}

(1)気体, 水蒸気, 光の透過がなく, 常温で 2 年間 の食品保存性がある (表 1). (2)内外面の白色 CPP に より清潔でソフトな外観を有する.（3)湯殺菌, $120^{\circ} \mathrm{C}$ のレトルト殺菌が可能. (4) アルミ䇴容器より強度が あり，かつ手による圧潰も可能という適度な剛性を有 する. (5)イージーピーラブル蓋との組合せにより, 優れた易開封性が得られる：(6)東洋製罐が独自に開 発した窒素ガス置換方式の「ナイスパック (NiSVAC) システム」により, ヘッドスペースの酸 素に敏感な食品への適用も可能.

\section{3. 成形方法}

成形プロセスは，ロール供給されたラミネート材の 打抜・成形工程, フランジ周縁部のカーリング工程, カール部をシール面より下げるカールリフォーム工程 からなる. 成形法の特徵は, 金属パンチの代りに金属 の芯材に合成ゴムを巻いた弾性体パンチを用いている こと.これにより側壁部にシワが全くない容器が得ら れる.

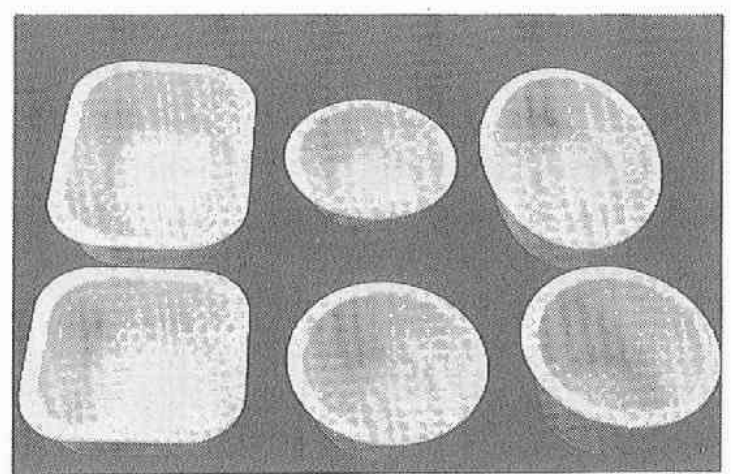

\section{写真 1}
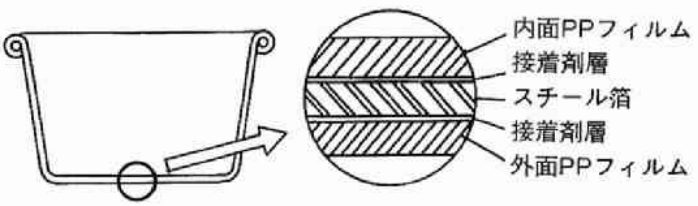

図 1 ハイレトフレックスの材料構成

表 1 ハイレトフレックスの保存性

\begin{tabular}{|c|c|c|c|c|c|c|}
\hline & \multirow{2}{*}{$\begin{array}{c}\text { 殺菌条件 } \\
\text { (温度, } \\
\text { 時間) }\end{array}$} & \multirow{2}{*}{$\begin{array}{l}\text { (保存条件 } \\
\text { (温度,期間) }\end{array}$} & \multicolumn{2}{|c|}{$\begin{array}{c}\text { 保存後 } \\
\text { 接着強度 } \\
(\mathrm{kg} / 15 \mathrm{~mm})\end{array}$} & \multirow{2}{*}{$\begin{array}{l}\text { 特性評価 } \\
\text { 面 }\end{array}$} & \multirow[t]{2}{*}{ 適用 } \\
\hline & & & 側壁 & 底部 & & \\
\hline $\begin{array}{l}\text { オレンジ } \\
\text { せリー }\end{array}$ & $\begin{array}{l}95^{\circ} \mathrm{C}, \\
25 \text { 分 }\end{array}$ & $\begin{array}{l}\mathrm{RT}, 2 \text { 年 } \\
37^{\circ} \mathrm{C} \text { 6力 }\end{array}$ & $\begin{array}{l}1.0 \\
1.2\end{array}$ & $\begin{array}{l}1.2 \\
1.1\end{array}$ & $\begin{array}{l}\text { ピタミンC } \\
\text { 残存率 }\end{array}$ & 可 \\
\hline $\begin{array}{l}\text { フルーシ } \\
\text { ソース }\end{array}$ & $\begin{array}{l}95^{\circ} \mathrm{C}, \\
25 \text { 分 }\end{array}$ & $\begin{array}{l}\mathrm{RT}, 2 \text { 年 } \\
37^{\circ} \mathrm{C} \text { 6力月 }\end{array}$ & $\begin{array}{l}1.3 \\
1.5\end{array}$ & $\begin{array}{l}1.2 \\
1.4\end{array}$ & $n$ & $n$ \\
\hline $\begin{array}{l}\text { 引らごし } \\
\text { リンざ }\end{array}$ & $\begin{array}{l}95^{\circ} \mathrm{C}, \\
25 \text { 分 }\end{array}$ & $\begin{array}{l}\mathrm{RT}, 2 \text { 年 } \\
37^{\circ} \mathrm{C} \text { 6か }\end{array}$ & $\begin{array}{l}1.7 \\
1.4\end{array}$ & $\begin{array}{l}1.5 \\
1.2\end{array}$ & $n$ & $\|$ \\
\hline $\begin{array}{l}\text { レバー- } \\
\text { ベースト. }\end{array}$ & $\begin{array}{c}115^{\circ} \mathrm{C}, \\
45 \text { 分 }\end{array}$ & $\begin{array}{l}\mathrm{RT}, 2 \text { 年 } \\
37^{\circ} \mathrm{C} \text { 6力 }\end{array}$ & $\begin{array}{l}1.0 \\
1.2\end{array}$ & $\begin{array}{l}1.9 \\
1.1\end{array}$ & POV & $n$ \\
\hline $\begin{array}{l}\text { y+r゙vッ } \\
\text { シンダ }\end{array}$ & $\begin{array}{c}120^{\circ} \mathrm{C}, \\
35 \text { 分 }\end{array}$ & $\begin{array}{l}\mathrm{RT}, 2 \text { 年 } \\
37^{\circ} \mathrm{C} \text { 另月 }\end{array}$ & $\begin{array}{l}1.1 \\
1.3\end{array}$ & $\begin{array}{l}1.2 \\
1.2\end{array}$ & $\|$ & "I \\
\hline $\begin{array}{l}\text { ポテト } \\
\text { サラダ }\end{array}$ & $\begin{array}{c}115^{\circ} \mathrm{C}, \\
40 \text { 分 }\end{array}$ & $\begin{array}{l}\text { RT,2年 } \\
37^{\circ} \mathrm{C} \text { 6力 }\end{array}$ & $\begin{array}{l}1.2 \\
1.1\end{array}$ & $\begin{array}{l}1.1 \\
1.2\end{array}$ & 色の変化 & " \\
\hline $\begin{array}{l}\text { ワイン } \\
\text { ゼリー }\end{array}$ & $\begin{array}{l}95^{\circ} \mathrm{C}, \\
11 \text { 分 }\end{array}$ & $\begin{array}{l}\mathrm{RT}, 2 \text { 年 } \\
37^{\circ} \mathrm{C} \text { 另月 }\end{array}$ & $\begin{array}{l}1.5 \\
1.6\end{array}$ & $\begin{array}{l}1.5 \\
1.7\end{array}$ & $\begin{array}{c}\text { 色の変化 } \\
\mathrm{pH}\end{array}$ & $n$ \\
\hline $\begin{array}{l}\text { ゆで } \\
\text { あずき }\end{array}$ & $\begin{array}{c}117^{\circ} \mathrm{C}, \\
50 \text { 分 }\end{array}$ & $\begin{array}{l}\mathrm{RT}, 2 \text { 年 } \\
37^{\circ} \mathrm{C} \text { 6力 }\end{array}$ & $\begin{array}{l}1.6 \\
1.5\end{array}$ & $\begin{array}{l}1.5 \\
1.7\end{array}$ & 色の変化 & $\eta$ \\
\hline
\end{tabular}

\section{4. ハイレトフレックスの採用例}

(1)フルーツゼリーなどのデザート食品, (2) 焼と り,さざえの塩焼などのおつまみ類，(3)コーンポタ ージュ, パンプキンペーストなどのベピーフード.

\section{東洋製罐（株）}

恶100 東京都千代田区内幸町 1-3-1

జా 03-508-8855 FAX 03-503-8631 


\section{MX ナイロン}

\section{ガスバリアー材料（ポリアミド MXD 6 樹脂）}

\section{1. 技術の背景}

『MXナイロン』とは, メタキシリレンジアミン (MXDA) を用いた三菱瓦斯化学(株) のポリアミド の総称である.

なかでも MXDA とアジピン酸からなる『MXナイ ロン』は高強度・高弾性率といった特徵だけでなく, 高いガスバリアー性を有し, 成形加工性に優れるた め, 成形材料, 包装材料をはじめとしてモノフィラメ ントやポリマーアロイなど幅広い用途への応用が期待 されている.

成形材料としては, 当社より『レニー』の商品名で 上市されているが，ここではその他の用途について述 ベる.

\section{2.「MX ナイロン』の特幑と用途}

ガスバリアー材料として「MX ナイロン」は次の 特幑を有している.

（1）湿度による酸素透過率の変化が小さい.

（2）適度な結晶化速度を有し, 成形加工性に優れる.

（3）熱安定性に優れ，ゲル発生が少なくリサイクルが 容易である.

（4）ポリオレフィンと組み合わせた多層容器はレトル 卜処理後もガスバリアー性が良好でその回復も速 やかである.

これらの特徴から『MX ナイロン」を PET, PP ある いは PEなどと組み合わせて, ガスバリアー性に優れ た容器, シートあるいはフィルムを得ることができ る.

例えば，『MX ナイロン」/PET の共射出延伸ブロ 一成形による多層ポトルは, 既に市場で好評を博して いる. 例えば, PET 層の厚みの 7 10\%の『MX ナ イロン』層を使用すると, 酸素透過率を PET 単層ボ トルの約半分にすることが可能である.

また, 『MX ナイロン」/PP 多層容器をレトルト処 理すると, 処理後 60 日間の透過酸素量は同一構成の $\mathrm{EVOH} / \mathrm{PP}$ 品と比較して, 3 分の 1 以下である.

\section{3. 将来動向}

上記以外の包装材用途にもざまざまな検討が進めら れている. また, 包装材以外の用途，例えばモノフィ ラメントやポリマーアロイの分野にも，『MX ナイロ ン」の高強度・高弾性率や特幑ある結晶化挙動の性質 に着目した実用化が試みられている。

『MX ナイロン」の今後の展開が期待される.
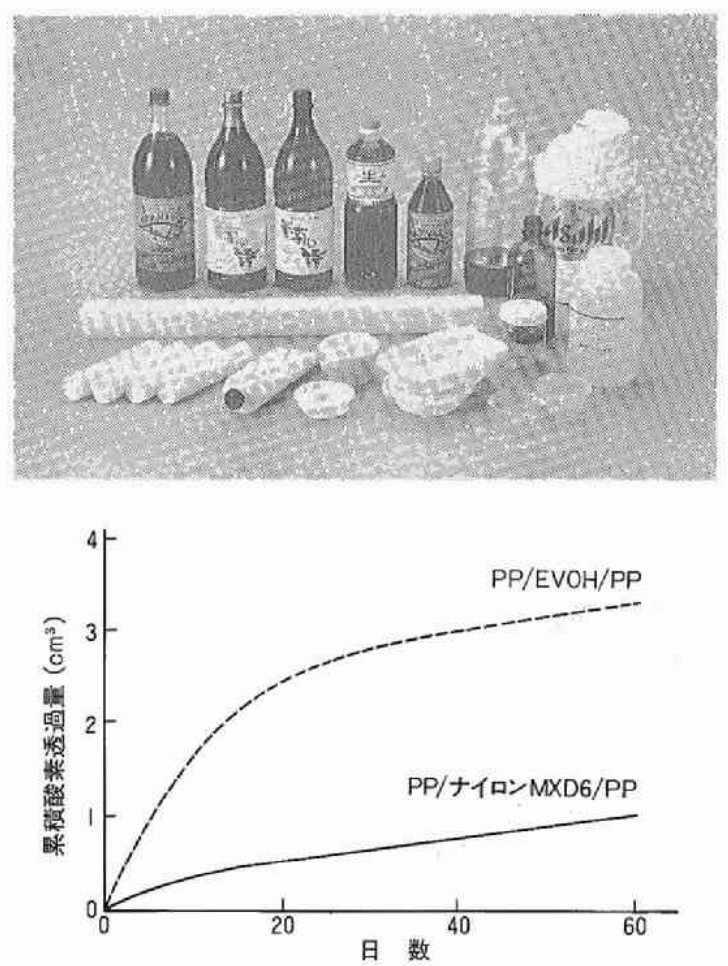

$$
\begin{aligned}
& \begin{array}{ll}
\mathrm{EVOH} & : \text { エチレン32モル\% } \\
\text { レトルト条件 } & : 120^{\circ} \mathrm{C}, 30 \text { 分 }
\end{array} \\
& \text { 容器仕様 : 表面積 } 200 \mathrm{~cm}^{2} \text {, 内容積 } 300 \mathrm{~cm}^{3} \\
& \text { PP/ガスバリアー層 : 200/20/200(ミクロン) } \\
& \text { 条件 }: 23^{\circ} \mathrm{C} \\
& \text { 内側 : 100\%RH } \\
& \text { 外側: } 50 \% \mathrm{RH}
\end{aligned}
$$

図 レトルト処理後の多層容器の累積酸素透過量

\section{三菱瓦斯化学 (株)}

石油化学品開発部

—100 東京都千代田区丸の内 2-5-2 (三菱ビル)

203-283-4815 FAX 03-214-0938 


\section{ヨイナーカプセル}

\section{セキスイレジンカプセルアンカー}

\section{1. 技術の背票}

ジョイナーカプセルは，積水化学工業が長年の実續 をもつ粘接着技術をべースに新しく開発した土木建築 用のカプセル型アンカーボルト固着剤である。

本製品は，コンクリートや岩盤などの母材に穿孔し た孔内にボルトを固着させ一体化を図る後付け工法用 に使用される。

従来のコンクリート打設養生前にボルトをセットす る方法に比べ，取り付き精度が大幅に向上する。 た，従来の後付け用金屬㧒張アンカーと比較して，接 童による一体化が図られるため耐层性に優れているな どの理由から，建設分野において多方面への使用が期 待される。

\section{2. 構造と種類}

ジョイナーカプセルは, 主剤樹脂, 硬化剤㧍よびセ ラミック骨材を収容した密栓二重ガラス管構造となっ ている。

製品峏耐食ポリエステル系（ジョイナーカプセル SP) およびエポキシ系（ジョイナーカプセル SE）の 2 種類あり，そのカプセル標準サイズは表に示すよう に使用ボルトに適合した 9 サイズから成っている。

\section{3. 特徴および用途}

ジョイナーカプセルの特徵は, 耐アルカリ性に優れ た樹脂および粒径の均一なセラミック骨材を使用して いるため, 固着強度が安定で経時変化がほとんどな く，また，施工作業性にも優れていることである，特 に, エポキシ系（ジョイナーカプセル SE）について は低温施工においても短時間で硬化するという従来の エポキシ系にはなかった特徽を有しているとともに， 高いレベルの固着強度と非常に優れた耐振動性が得ら れる.

ジョイナーカプセルは, 後付けアンカー工法に使用 されるが, 強固で安定した固着力を有することから設 備機械の据付, 空調ダクト吊り, 防音壁取付けなどの 特に耐振施工用途への展開が今後もますます期待され る.

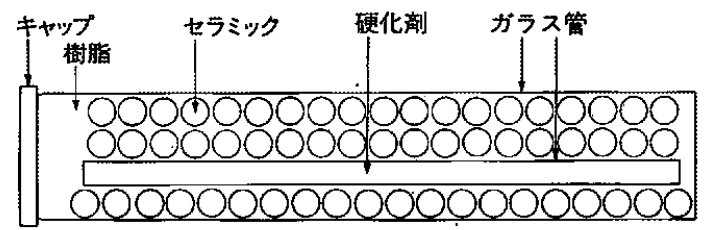

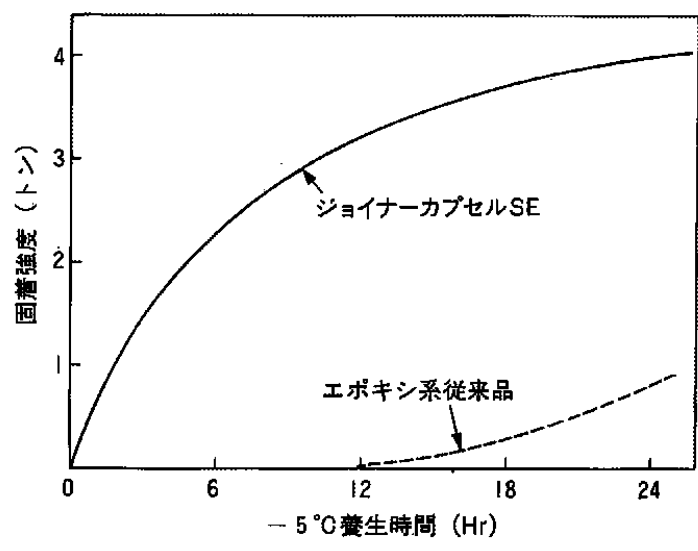

図 ジョイナーカプセル SE の低温固苒強度 $\left(-5^{\circ} \mathrm{C}\right)$

表 製品檟準サイズ

\begin{tabular}{|c|c|c|c|}
\hline \multirow{2}{*}{ 種 類 } & \multicolumn{3}{|c|}{ カプセル } \\
\hline & 外 径 $(\mathrm{mm})$ & 度 さ (mm) & 容 $\left(\mathrm{cm}^{2}\right)$ \\
\hline SP-8, SE-8 & 8 & 70 & 3.5 \\
\hline$S P-10, S E-10$ & 10.5 & 80 & 5 \\
\hline SP-12,SE-12 & 13 & 85 & 8.5 \\
\hline SP-16, SE-16 & 16.5 & 110 & 21 \\
\hline $\mathrm{SP}-20, \mathrm{SE}-20$ & 20 & 150 & 43 \\
\hline $\mathrm{SP}-22, \mathrm{SE}-22$ & 24 & 200 & 85 \\
\hline SP-24, SE-24 & 28 & 250 & 145 \\
\hline SP-30, SE-30 & 35 & 300 & $260^{\circ}$ \\
\hline $\mathrm{SP}-36, \mathrm{SE}-36$ & 40 & 350 & 420 \\
\hline
\end{tabular}

\section{積水化学工業（株）}

化学品部門 ケミカルスペシャリティ事業部 接着剂企画部

巴530 大阪市北区西天満 2-4-4

806-365-4531 


\section{タケライト UV-500}

\section{UV 硬化型プリントラミネート用接着剤}

\section{1. はじめに}

プリントラミネーションは，印刷された紙とフィル ムを貼り合わせ, インキの保護，美粧性，耐水性など を目的として行われ，医薬品，化粧品の箱，あるいは 書籍の表紙，ポスターなどに利用される．現在用いら れているプリントラミネート用接着剮の大半はトルエ ンや酢酸エチルなどの有機溶剂を用いた溶剤型接着剤 であるが，最近は次のような理由により，接着剤の改 良が進んでいる。

（1）流通の近代化により，ロットの小型化，納期の短 縮化などが要請され，生産合理化，スピードアッ プの対応が急務となっている。

（2）安全衛生，環境污染に対する意識向上，あるいは 省エネルギー，省資源の要請により，水性化，脱 溶戍化への試みがなされている。

このような状況下で武田薬品工業（株）は，プリン トラミネート用接着剤として, UV（紫外線）による 硬化方式を用いたタケライト UV-500 を開発した。

\section{2. タケライト UV-500 の特徵}

（1）UV 照射すると直ちに硬化を完了する，したがつ てラミネートされた製品はすぐに出荷可能とな り，短納期の実現が可能である。

(2) OPP, PVC, PET および OPS などの各種のフ イルムに良く接着する。

（3）アート紙，コート紙，合成紙，PVC，PET，ア ルミ蒸着紙などの各種の基材に良く接着する.

（4）指着剤は一液型で UV 照射しない限り安定なの で, 使用時の增粘やゲル化がなく使用後の廃液も 出ない,

（5）溶剂として水溶性アルコールを使用しているの で, 使用中は溶剤の希散が少なく, 樹脂の粘度上 昇や．溶剤臭が少ない，また，UV 硬化型樹脂で あるにもかかわらず特有の異臭がない，

（6）ラミネート品は光沢, 透明性, 耐候性および霜黄変 性に優れている，同時に柔軟性にも富むので折曲 げ，㗪線および深絞り加工などに十分耐え得る。

（7）UV 照射前㹥柔らかく平滑性が良いので，基材へ のフロー性が良い.したがって圧着ロール忏ほと んど加熱を要しないのでラミネート品は熱による 変型がない。

（8）この接着剤は既存のプリントラミネーターに若千 の改造を加えて UV ランプを設置すれば使用可 能となる。
表 1 タケライト UV-500 の接著性能（一r例）

\begin{tabular}{|c|c|c|c|c|c|c|}
\hline \multirow{2}{*}{$\begin{array}{c}\text { フィルム } \\
\text { 基材 }\end{array}$} & OPP & PVC & $\mathrm{PET}$ & $\mathrm{OPP}$ & PVC & OPS \\
\hline & アート紙 & コート紙 & アート紙 & 合成紙 & ステッカー & アート紙 \\
\hline 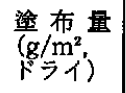 & 4.0 & 5.5 & 4.5 & 5.0 & 5.0 & 5.0 \\
\hline $\begin{array}{c}\text { 運転速度 } \\
(\mathrm{m} / \text { 分 })\end{array}$ & 30 & 25 & 20 & 30 & 25 & 25 \\
\hline $\begin{array}{r}\text { UVランプ } \\
(\mathrm{W} / \mathrm{cm}) \\
\end{array}$ & 120 & 120 & 120 & 120 & 120 & 120 \\
\hline 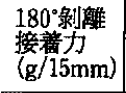 & $\begin{array}{l}150 \sim 200 \\
(\text { (紙材破) }\end{array} \mid$ & 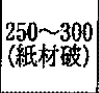 & $\begin{array}{l}200 \sim 250 \\
(\text { 絓材破) }\end{array}$ & $\begin{array}{l}200 \sim 250 \\
(\mathrm{OP} \text { 切 })\end{array}$ & $\mid \begin{array}{c}200 \sim 250 \\
(\mathrm{OP} \text { 切 })\end{array}$ & $\begin{array}{l}250 \sim 300 \\
(\text { 紙村醊) }\end{array}$ \\
\hline $\begin{array}{c}\text { 耐熱クリ } \\
-7(\mathrm{~mm}) \\
\left(50 \mathrm{~g}, 50^{\circ} \mathrm{C}\right)\end{array}$ & 0 & 0 & 5 & 3 & 0 & 0 \\
\hline $\begin{array}{l}\text { 耐ヶロシ } \\
\text { シ性 } \\
(5 \mathrm{sec} \\
24 \mathrm{hr} \text { 後) }\end{array}$ & 良 好 & 良 好 & 良 好 & 良 好 & 良 好 & 良 好 \\
\hline $\begin{array}{c}\text { 耐折曲性 } \\
\left(50^{\circ} \mathrm{C}\right. \\
60 \mathrm{~min}) \\
\end{array}$ & 良 好 & 良 好 & 良 好 & 良 好 & 良 好 & 良＼cjkstart好 \\
\hline 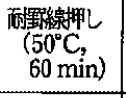 & 異常なし & 異常なし & 翼常なし & 異常なし & 異常なし & 異常なし \\
\hline 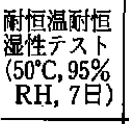 & 良 好 & 良 好 & 良 好 & 良，好 & 良 好 & 良 好 \\
\hline $\begin{array}{l}\text { 耐候性テス } \\
\Gamma\left(60^{\circ} \mathrm{C}\right. \\
40 \mathrm{hr}) \\
\end{array}$ & 良 好 & 良 好 & 良 好 & 良 好 & 良 好 & 良 好 \\
\hline $\begin{array}{l}\text { 外 解 } \\
\text { (光沢) }\end{array}$ & 良 好 & 良 好 & 良 好 & 良 好 & 良 好 & 良 好 \\
\hline
\end{tabular}

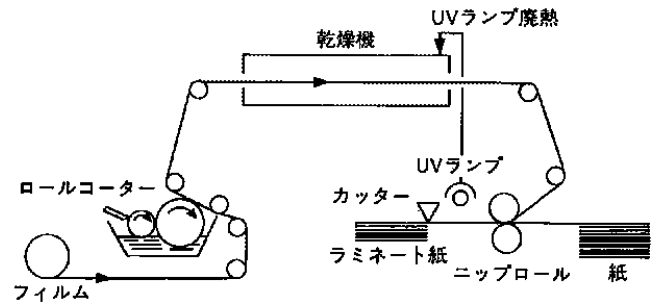

図 1 タケライトUV-500 のシステム

\section{武田薬品工業（株）}

化学品事業部営業第 4 部

亚 103 東京都中央区日本㗚 2-12-10

203-278-2777

- 541 大阪市東区道修町 2-27

- 06-204-2480 


\section{NUC-ACE GA-007/GB-401}

\section{接着性ポリオレフィン}

\section{1. 技術の背暴}

多尿フィルム，多層テープ用材料が，ますます高機 能，多様化していくなかで，その接着用材料にも，新 しい機能, 合理的な価格が要求されている，日本ユ二 カーの “GA-007”と“GB-401” は, 接着性ポリオ レフィン, NUC-ACE シリーズのなかで, 特に, 2 種以上の官能基を導入し，金属，塩ビ，ポリアミド, ポリカーボネート，ケン化 EVA などに強固に接着す るよう設計したものである.

\section{2. 特徵および用途}

（1）各種基材に対する接着強度を表 1 に示した。

（2） GA-007，GB-401 とも，容易にフィルム化でき る. 通常のインフレーション法で, $20 \mu \sim 100 \mu$ の フィルム製造が可能である。このフィルムを熱ロー ルで被着体に接着する。金属簿（例えば鉛箔）とプ ラスチックス（例えば塩ビ）の接着層に最適であ る。融点は $120^{\circ} \mathrm{C}$ ，望ましい接着温度は $150^{\circ} \mathrm{C}$.

(3) GB-401 の場合, 基材に直接押出しコーティング もできる。

（4）耐水性，熱安定性が良い。空気中での熱分解開始

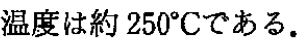

（5）他樹脂との相溶性が良い。したがって例えばポり プロピレンにブレンドして接着性を付与できる。

（6）またプラスチックスの相溶化戍として使用でき る.

（7）硬質塩ビなどの衝撃改良肪に利用できる。また， 各種のフィラー入りコンパウンドの改質が期待でき る.

\section{3. その他}

GA-007，GB-401 は変性ポリオレフィンで，昅湿 性や経時劣化はない，一般的物性は表 2 に示した。

フィルムの特性の一例を示すと, インフレ法で作っ た GB-401の $50 \mu$ のフィルムは, 引張強さ $250 \mathrm{~kg} /$ $\mathrm{cm}^{2}$ 伸び 700\% (MD).ブロッキング防止のため特殊 処方されている。

一般的に接着性フィルムには，低温接着性と，酎熱 性という相反する特性が要求される，GA-007のビカ ーット軟化点は比較的高いが, 必ずしも十分でない. GA-007，GB-401とも，パーオキサイドや照射で架 橋可能で耐熱性を向上できる。
衰 1 接雃強度 $(\mathrm{kg} / \mathbf{1 5} \mathrm{mm})$

\begin{tabular}{l|r|r|c}
\hline \multicolumn{1}{c|}{ 基 材 } & GA-007 & GB-401 & $\begin{array}{l}\text { 参 考 } \\
\text { NUCACE } \\
\text { GA-002 }\end{array}$ \\
\hline 鉄 箔 & 3.5 & 10.5 & 4.0 \\
アルミ箔 & 3.0 & 11.0 & 3.5 \\
鉛 簿 & 1.0 & 3.0 & 1.0 \\
ポリ塩化ビニル(硬質) & - & 5.5 & - \\
6ナイロン & 8.0 & 3.5 & - \\
ポリカーボネート & 1.0 & 10.0 & - \\
ケン化 EVA & 10.0 & 10.0 & - \\
ポリステレン & - & 6.0 & - \\
\hline
\end{tabular}

接着条件 : 基材/接着層 $(50 \mu) / ア ル ミ$ 簿という棈

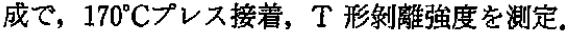

表 2 一般物性

\begin{tabular}{|c|c|c|c|}
\hline 物 性(単位) & 試就㑒法 & GA-007 & GB-401 \\
\hline $\begin{array}{l}\text { メルトインデックス } \\
\text { (g/10 min) }\end{array}$ & K 6760 & 0.2 & 1.2 \\
\hline 密 度 $(\mathrm{g} / \mathrm{m} l)$ & m & 0.900 & 0.926 \\
\hline 引張強さ $\left(\mathrm{kg} / \mathrm{cm}^{2}\right)$ & " & 260 & 140 \\
\hline 伸 び(\%) & $n$ & 810 & 800 \\
\hline ショア硬度 & D 2240 & 43 & 28 \\
\hline 融 点 $\left({ }^{\circ} \mathrm{C}\right)$ & DSC & 120 & 120 \\
\hline ビカーット軟化点 $\left({ }^{\circ} \mathrm{C}\right)$ & K 7260 & 86 & 56 \\
\hline
\end{tabular}

$$
\text { 日本ユニカー (株) }
$$

商品開発部

E 100 東京都干代田区大手町 2-6-1

- 03-270-2552 


\section{アレスフロン}

NAD一非水ポリマーディスパージョンー型フッ素樹脂

アレスフロンは，簡便に施工できる有機貿系塗料の なかで最も優れた品質と耐久性を持った高耐候性常温 硬化 NAD 型フッ䒺樹脂塗料である.

$\mathrm{NAD}$ 型フッ素樹脂は, 当社が永年にわたり蓄積し てきた NAD 合成技術により，世界に先駆けてアクリ ル系ミクロスフェアを溶剤可溶型フッ素樹脂中に安定 かつ均一に分散させたものである。

\section{1. 技術の背景一目的・方法}

恧候性・耐化学薬品性に優れるフッ素樹脂の特長と 機械的性貿などの設計の自由度の大きいアクリル樹脂 の特長を伴せ持つ複合系ポリマーの開発を目的とし た.

これを, 溶㓮可溶型フッ素樹脂一フルオロエチレン ビニルエーテル共重合体一を分散安定剤とする $\mathrm{NAD}$ の合成により達成した.アクリル粒子はサブミクロン 級 $(0.1 \sim 1.0 \mu \mathrm{m}$ の範囲で自由に制御できる）の粒 子として安定に存在する. 得られるフィルムはミクロ 不均一搼造をとっており, 連続相はフッ素樹脂, 分散 相はアクリル樹脂からなっている（図 1).

\section{2. 特幑および用途}

アレスフロンは以下の多くの特徵を持っている.

1. 溶刘可溶型常温硬化フッ素樹脂の高耐候性が維 持できた（図 2)。

2. 塵埃などによる污染を受けにくい.

3. 水との接触角が大きく, 濡れ難い.

4. 紫外線遮蔽効果により下地保護に優れる.

5. 耐化学薬品性, 而水性に優れる.

6. 酸素透過性, 水蒸気透過性がともに低い.

7. 涍膜の機械的特性の設計が容易に行える.

8, 架橋性, 乾獭性に優れ作業時間の短縮化が可 能.

9. 耐溶剤性に優れ, チヂミを発生し難い.

10. NAD の特徴である構造粘性を示し, タレ難く

肉持感のある塗膜が得られる.スプレー, ローラ 一, 八ケ塗り作業性に優れる.

推奨周途は, 建築外装材の仕上用, 建築物外部鉄部 の上塱, カーテンウォールの新設および望替, 長期間 の防食, 耐候性が要求される土木構造物の上塗などで ある。

なお上記特長はフッ䒺樹脂とアクリル樹脂とのグラ フト化，あるい霖者の単なるブレンドでは得られな かった. NAD 型フッ素樹脂から得られる塗膜におい てのみ, 連続相（表面層も）がフッ素樹脂からなり,
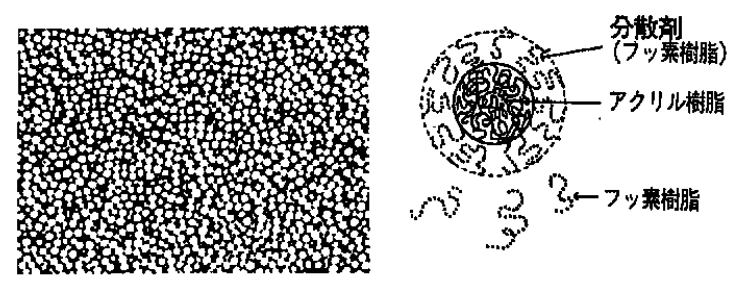

図 1 NAD 㤠フッ察橵脂硬化塗膜の TEM 写蒖 および NAD 概念図

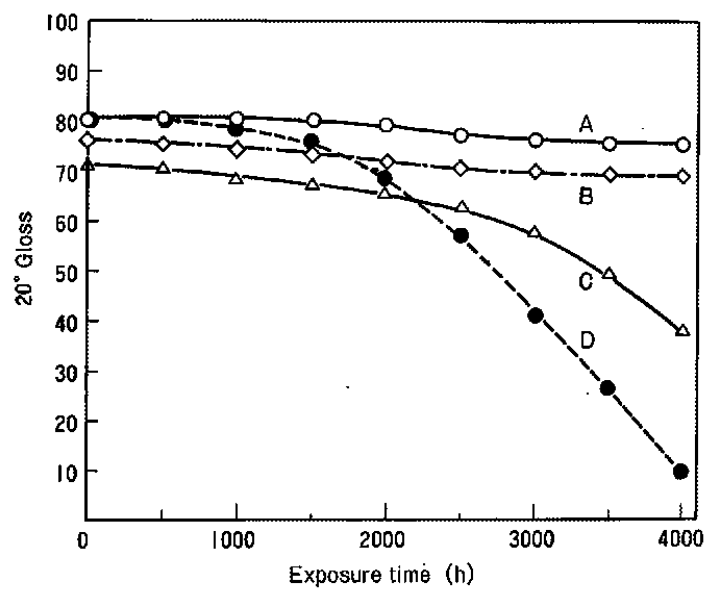

A. アレスプロン B. 当社常温硬化フッ亲樹脂塗料

C. 常温硬化フッ禁樹脂/常温硬化アクリル混合系料

D. 常温硬化アクリル塗料

いずれも，イソシアネート系硬化昘で架檽硬化させた。

図 2 促進耐候性試験 (SWOM)

分散相がアクリル樹脂からなるミクロ不均一構造が形 成される。この構造のためにフッ素樹脂の特長を維持 したまま耐污染性, 機械的性能, 硬化性の補強, レオ ロジー特性の付与が達成できたものと考えられる。

\section{関西ペイント (株)}

技術研究所 1 部

巴254 神奈川県平塚市東八憣 4-17-1

20 0463-23-2101

FAX 0463-21-6872 


\section{セフラルコート}

\section{溶剂可溶型塗料用フッ素樹脂}

\section{1. 技術の背睘}

従来, 鋼板,アルミなどの耐食, 耐候性コーティン グ剤として用いられてきた四フッ化エチレン樹脂およ びフッ化ビニリデン樹脂塗料は，いずれも造膜温度が 高く, 230 380 Cでの焼付が必要であり, 用途が制限 されていた。セントラル硝子は, フッ素の化学につい て培った技術をもとに, 独自に常温での造膜が可能な 溶剤可溶型フッ素樹脂 “セフラルコート”を開発し た.

\section{2. 特徽と用途}

セフラルコートは, 酎候性; 耐污染性に優れたフッ 素樹脂である，硬化前は，ケトン，エステル，塩素系 溶剤, 芳香族系溶剤に溶けるので，これらの溶剤を用 い塗料化し，スプレーガン，朋毛，ローラーなどによ り現場施工することが可能である．また，セフラルコ ートは,イソシアネートなどの硬化剈と反応しうる官 能基を有しており, 塗装後は架橋反応により耐薬品性 が向上する．表 $1 に$ ，セフラルコート硬化塗膜の基本 特性を示した。

セフラルコートのイソシアネート硬化品は, 225 $\mathrm{nm}$ より光を透過し始め, $300 \mathrm{~nm}$ ではほとんど光を 吸収しない。また，地上での太陽光のスペクトルに は, $300 \mathrm{~nm}$ 以下の波長の紫外線は，0.01\% と極くわ ずかしか含まれていない。このことは，セフラルコー トの太陽光の吸双率が大変低いことを示し, さらに, セフラルコートの劣化の速度が非常に遅くなることを 示唆する. セフラルコートの高耐候性は, 促進霜候性 試験によって実証された。これに対し，アクリルウレ タン塗膜は, $300 \mathrm{~nm}$ より長波脣の光線をかなり吸取 する。

現在, セフラルコートは, 耐候性, 耐污染性（污れ の取り易さ）などを生かし，建築物の上塗り塗料用 に, また, 耐候性, 酎薬品性を生かし, 化学プラント の防食望装の上塗り塗料用に市場開拓中であるが，さ らに，車輛，橋梁などに対する上塗り塗料向に用途開 発を行う予定である。
衰 1 セフラルコート硬化哛膜の基本特性

\begin{tabular}{l|c}
\hline \multicolumn{1}{c|}{ 試 験 項 目 } & \multicolumn{2}{c}{ セフラルコート } \\
室温硬化
\end{tabular}

*) 硬化剂：ヘキサメチレンジイソシアネート三量体

\section{セントラル硝子（株）}

本社 化成品研究開発部弗素樹脂開発室

要 101 東京都千代田区神田錦町3-7-1 (興和一檽ビル)

o $03-259-7375$

大阪支店 弗素樹脂課

e 530 大阪市北区兽根崎 2-5-10 （梅田三井ビル）

206-315-1541 


\section{SOLDEREX K1000}

\section{アルカリ現象型液状フォトソルダーレジスト}
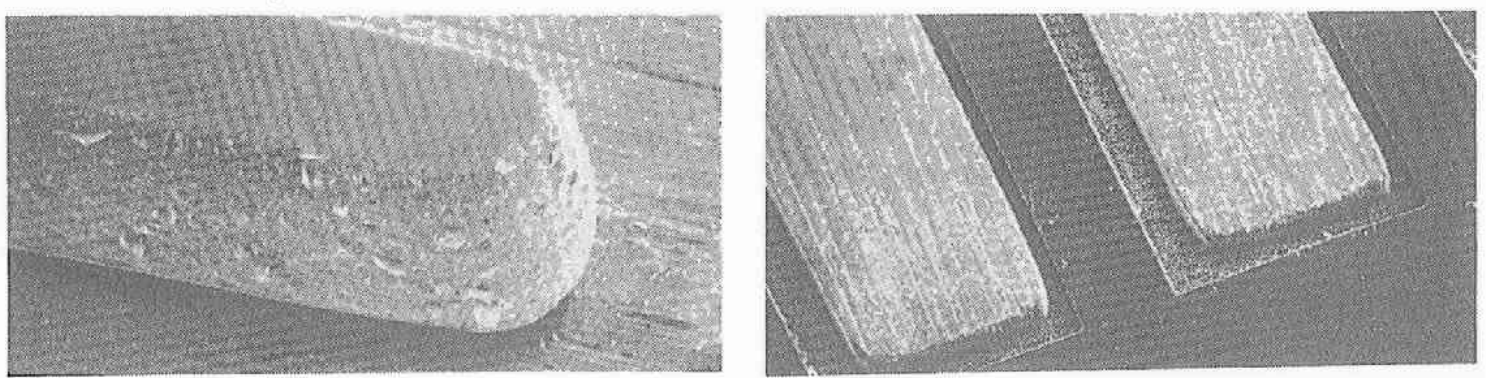

電子顕微鏡写真

プリント配線板の高密度化や表面実装化などが急ピ ッチで進む今日, 従来のスクリーン印刷によるソルダ ーレジストでは対応できない基板が増えており，写真 法でパターンニングできる液状フォトソルダーレジス トへの転換が進められています，しかし，1,1,1-トリ クロロエタンを使用する溶㓮現像タイプは公害問題な どから，今後その使用がますます困難になっており， アルカリ現像型の液状フォトソルダーレジストの登場 が切望されていました。

アルカリ現像型液状フォトソルダーレジスト 「SOLDEREX K1000」は, これからの時代の高解像 度，低公害のソルダーレジストです。

\section{1. 製品概要}

SOLDEREX K1000 には汎用タイプの D11, 高品 質タイプの $\mathrm{D} 12$ と 2 種類のグレードがあります. 各 グレードの特徵は以下のとおりです，使用目的に合せ て御選び下さい.

D11 の特微

（1）プレベーク時の熱かぶりがない.

（2）マスクフィルムの貼付きが少なく，作業性が技群 に優れています。

（3）裏露光の少ない設計のため，両面同時露光が容易 です.

（4）水溶性フラックスに対し安定です.

（5）電解金メッキに対し安定です.

D12 はさらに下記の特徵があります.

（1）水溶性フラックス，特にケンコ\# 183 など浸透性 の強いフラックスに対し安定です.

（2）電解金メッキに対し安定です. $1.5 \mu$ 厚までの金 メッキに耐性があります.

\section{SOLDEREX K1000 の特性}

特性を表に示します それぞれのグレードについて は, 詳しい技術資料を用意してありますので御請求下 さい.
表 SOLDREX K 1000 の特性

\begin{tabular}{|c|c|c|c|}
\hline \multicolumn{4}{|c|}{ 1ンキの特性 } \\
\hline \multicolumn{2}{|c|}{ タイர゙ } & \multicolumn{2}{|c|}{2 波混合型 } \\
\hline \multicolumn{2}{|c|}{ 色 調 } & \multicolumn{2}{|c|}{ 緑 色 } \\
\hline \multicolumn{2}{|c|}{ 固型分 } & \multicolumn{2}{|c|}{$79 \pm 1 \%$} \\
\hline \multicolumn{2}{|c|}{ 粘 度 $\left(25^{\circ} \mathrm{C}\right)$} & \multicolumn{2}{|c|}{$200 \pm 20$ ps } \\
\hline 保存期間 & $\left(25^{\circ} \mathrm{C}\right)$ & \multicolumn{2}{|c|}{$\begin{array}{l}2 \text { ケ月 } \\
6 \text { ケ月 }\end{array}$} \\
\hline \multicolumn{2}{|c|}{ ポットライフ } & \multicolumn{2}{|c|}{$12 \mathrm{hr}$ ( 2 液混合後 $)$} \\
\hline \multicolumn{2}{|c|}{ プレベータ } & \multicolumn{2}{|c|}{$\begin{array}{ll}\text { D } 11: 75^{\circ} \mathrm{C} & 20 \text { 分 } 45 \text { 分 } \\
\text { D } 12: 75^{\circ} \mathrm{C} & 20 \text { 分 } 30 \text { 分 }\end{array}$} \\
\hline \multicolumn{2}{|c|}{ 必要露光量 } & \multicolumn{2}{|c|}{$300 \sim 700 \mathrm{~mJ} / \mathrm{cm}^{2}$} \\
\hline \multicolumn{2}{|c|}{ 現 像 } & \multicolumn{2}{|c|}{ 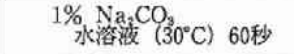 } \\
\hline \multicolumn{2}{|c|}{ 熱硬 化 } & \multicolumn{2}{|c|}{$140^{\circ} \mathrm{C} 40$ 分 } \\
\hline \multicolumn{4}{|c|}{ 硬化皮膜物性 } \\
\hline \multicolumn{2}{|c|}{ 㷱膜硬度 } & \multicolumn{2}{|c|}{$6 \mathrm{H}$} \\
\hline \multicolumn{2}{|c|}{ 密着性（銅上） } & \multicolumn{2}{|c|}{$100 / 100$} \\
\hline \multicolumn{2}{|c|}{ はんだ恧熱性 } & \multicolumn{2}{|c|}{$260^{\circ} \mathrm{C} 15$ 秒 10 サイクル 良好 } \\
\hline \multicolumn{2}{|c|}{ 耐溶坟性メチレン) } & 常温60分漫漬 & 良好 \\
\hline \multirow[t]{2}{*}{ 耐酸性 } & $\begin{array}{l}10 \% \\
\mathrm{HCl}\end{array}$ & 常温60分浸清 & 良好 \\
\hline & $\begin{array}{l}20 \% \\
\mathrm{H}_{2} \mathrm{SO}_{4}\end{array}$ & 常温60分漫滍 & 良好 \\
\hline 耐アルカリ性 & $10 \%$ & 常温60分浸湍 & 良好 \\
\hline 絶緑抵抗 & $\begin{array}{l}\text { 初期值 } \\
60^{\circ} \mathrm{C} 95 \% \\
\mathrm{RH} 1000 \mathrm{H}\end{array}$ & \multicolumn{2}{|c|}{$\begin{array}{l}1 \times 10^{13} \Omega \text { 以上 } \\
1 \times 10^{11} \Omega \text { 以上 }\end{array}$} \\
\hline \multicolumn{2}{|c|}{ 耐金メッキ性 } & \multicolumn{2}{|c|}{$1 \mu$ (D 11), $1.5 \mu$ (D 12) } \\
\hline 燃焼 & & UL 規格 94 & \\
\hline
\end{tabular}

東洋インキ製造（株）

\section{新事業開発部}

恶104 東京都中央区京橋 3-14-6 斉藤ビル 203-567-8161 


\section{トセエース ES}

\section{塩素化塩化ビニル樹脂}

\section{1. 技術の背景}

トセエース ES は，当社独自の塩化ビニルの重合技 術と塩素化技術により, 従来の塩索化塩化ビニル系樹 脂にはない，優れた溶剤溶解性を有する樹脂です。

トセエース ES は, 塩化ビニル系樹脂が本来有す る, 耐水性, 耐薬品性, 耐候性, 印刷特性などの性能 を損なうことなく，塩素化塩化ビニル系樹脂の特徴で ある, 耐熱性, 強靱性, 難燃性を付与した樹脂であ り, 各種溶削への溶解性に優れている点より，各種の 塗料, 接着剤，インキのバインダーなどへの輻広い用 途展開が可能です

2. 特徵

（1）耐熱性，強靶性，耐摩耗性に優れています。

（2）各種溶剤への溶解性に優れており，溶滆種の選択 により，高濃度化も可能です。

（3）各種樹脂との相溶性に優れています。

（4）塩素系溶斎を含んでおらず，安全です。

(5) 酸化チタンなどの顔料分散性に優れています。

（6）無味，無臭，無毒です。

3. 用途例

(1) 塗料用

イ）建築用，橋梁用などの防食塗料

口）船底中塗り塗料

八）塩化ビニル椥脂， ABS 樹脂などのプラスチッ ク用塗用

（2）インキ用

イ）特殊グラビアインキ

ロ）紙用グラビアインキ

八）建材用グラビアインキ

二)オーパーコートニス

ホ）転写用インキ

(3) 接着剂用

イ）ゴム系接着剂の耐熱向上

ロ）各種プラスチック用接着剤

4. 品種と物性

表に示す.
表 品種と物性

\begin{tabular}{|c|c|c|c|c|}
\hline & ES-951 F & ES-941 F & ES-941 M & ES-941 N \\
\hline 外 観 & 白色粉末 & 白色粉末 & 白色粉末 & 白色粉末 \\
\hline 掸発分 (wt\%) & 1 以下 & 1 以下 & 1 以下 & 1 以下 \\
\hline 平均重合度*1 & $450 \pm 30$ & $350 \pm 30$ & $300 \pm 30$ & $250 \pm 30$ \\
\hline $\begin{array}{l}\text { 塩素含有量 } \\
\text { (wt\%) }\end{array}$ & $63 \pm 1$ & $63 \pm 1$ & $68 \pm 1$ & $70 \pm 1$ \\
\hline $\begin{array}{l}\text { 办ラス転移点 } \\
\left({ }^{\circ} \mathrm{C}\right)\end{array}$ & 95 & 95 & 120 & 125 \\
\hline $\begin{array}{l}\text { 粘 度 }(\mathrm{cps})^{* 2} \\
\text { 签解性*3 }\end{array}$ & 70 & 40 & 40 & 40 \\
\hline MEK & $S$ & S & PS & I \\
\hline トルエン & S & $\mathrm{S}$ & $\mathrm{S}$ & $\mathrm{s}$ \\
\hline 酥酸エチル & PS & S & I & I \\
\hline
\end{tabular}

*1 平均重合度 : JIS K 6721

*2 粘 度：MEK/トルエン $1 / 1 \quad 20 \%$ 溶液 B 型粘度計

测定温度 $25^{\circ} \mathrm{C}$

*3 溶 解 性: S ; 溶解, PS ; 一部不溶解, I；不溶解

\section{積水化学工業（株）}

東京支店/化学品営業所 $\cdot \mathrm{CS}$ 担当

⿶105 東京都港区虎ノ門 3-4-7（虎ノ門 36 森ビル）

- 03-434-9308

近畿支店 /化学品営業所 $\cdot \mathrm{SP}$ 担当

⑤30大阪书北区西天満 2-4-4（堂岛関䉓ビル）

206-365-4329

製造元/徳山積水工業(株) 南陽工場

函 746 山口県新南陽市大字富田 4560

20 0834-63-0192 


\section{粉体塗料用ポリエステル樹脂}

\section{1. 技術の背景と市場動向}

粉体㴔料は大気污染や石油危機を契機に, 無公害, 省資源の観点から開発され，わが国でも本格的に採用 されて 10 年以上経過した, 粉体塗料使用量はわが国 では全塗料の $1 \%$ と少ないが, 欧米での使用量は 5〜 6\%と多くその伸び率も大であり, 今後日本でも同 程度まで伸びると期待されている。

熱硬化性粉体登料としては，わが国においてはポリ エステル・ウレタン系が主流であるが，世界的にはポ リエステル・ウレタン系, TGIC 系, エポキシ系, ポ リエステル/エポキシ・ハイブリッド系の使用量が多 い. それぞれ優れた特性を有しており, その特幑を活 かした用途に使用されている.

日本エステル (株) ではそれらの粉体叙料に適した ポリエステル樹脂について, 使用目的, 用途に応じ任 意に広範囲に選択できるよう, 多くのグレードを取り そろえている.

\section{2. 特徵および用途}

日本エステル (株) では硬化形式別に, 各種グレー ドの粉体塗料用ポリエステル樹脂を生産している. 硬化形式別

ウレタン硬化型ポリエステル樹脂

IPDI を主体としたイソシアナート硬化.

エポキシ樹脂硬化型ポリエステル樹脂

固形エポキシ樹脂硬化 (ハイブリッド).

TGIC 硬化型ポリエステル樹脂

TGIC などのグリシジル化合物硬化.

エポキシ硬化型ポリエステル樹脂

エポキシ化合物（硬化剤）を練り込んだ樹脂. グレード別

\section{基本グレード}

物性, 而候性などのバランスの取れたグレード.

多くの用途に使用可能.

耐候性グレード

耐候性が特に優れたグレード

フロリダ暴露試験での耐候性が実証済.

耐污染性グレート゚

耐マジックインキ性などの耐污染性に優れたグ

レード

高フロー性グレード

塗膜外観が優れたグレード.

樹脂の流動性が良く, 平滑な塗膜が得られる 低温硬化グレート゚

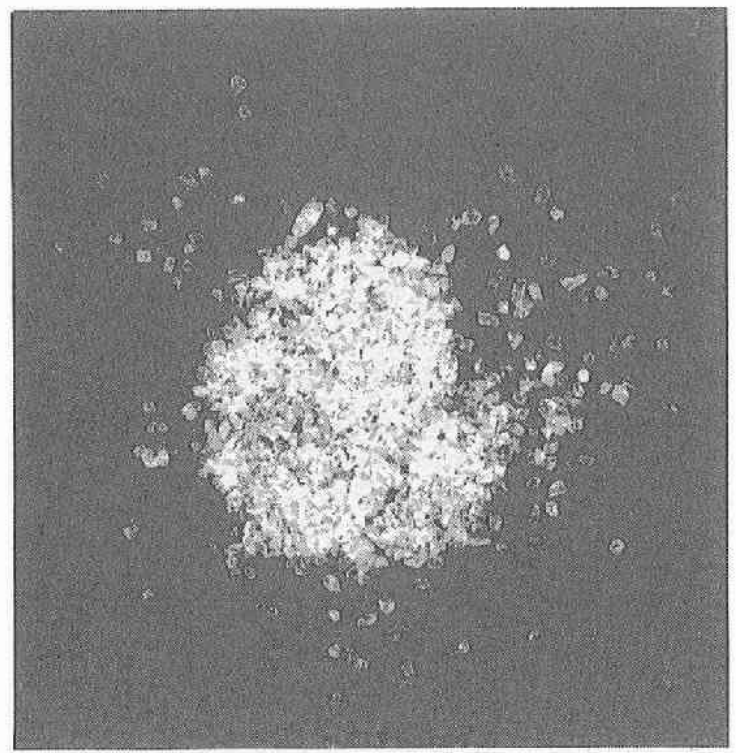

粉体淕料用ポリエステル樹脂

低温硬化 $\left(150^{\circ} \mathrm{C} \times 20 \mathrm{~min}\right)$ が可能のグレード プレコートメタル・グレード

加工性, 物性, 外観などの優れたグレード. 高䙵消しグレード

艶消し剂を必要としない高鄷消しク゚レード。

グロス $10 \%$ 以下が可能.

\section{3. 将来の動向}

粉体塗料は塗膜性能が優れており，また，将来的に は溶剂規制が戦しくなると予想されるので，今後も粉 体塗料の使用量はますます増大するものと思われる.

現在の主用途恰冷蔵庫などの家庭電気製品, 自動車 部品, 建材などであるが, 今後もそれらの分野での使 用量が拡大されるであろうし，また，スチール家具， 電子機器, 屋外設備などでの使用が進むであろう.

\section{日本エステル（株）}

표 531 大阪市北区中津 1-6-28

జా 06-372-0601 


\section{一液架橋型エマルション}

\section{アクリル系エマルション}

\section{1. 技術の背景}

アクリル系エマルションの用途の多様化あるいは高 性能化が進み, エマルションの性能に対する要求もま すます緟しくなってきている。一液架橋型エマルショ ン（SC-シリーズ）はこのような状況に対応するため に開発された高性能エマルションである。

\section{2. 特徵}

SC-シリーズは乳化剂として反応性高分子乳化㨈を 使用し，乳化㨈の親水基と乳化重合で生成したポりマ 一中の官能基とを水が飛散する過程で反応させるシス テムをとることにより，得られる皮膜を架撟体とし， かつ, 親水基を消失させ, その結果, 皮膜の雨水性, 密着性などの各性能が従来のエマルションに比べて著 しく向上しているものである.

特徴をまとめると下記の項目となる。

（1）常温ないし低温で架橋反応が進行する一液架橋型 エマルションである。

（2）耐水性が優れている。

（3）密着性が優れている.

（4）耐溶剤性が優れている.

(5) 耐ブロッキングが優れている.

（6）皮膜強度が優れている。

（7）眝蔵安定性が良好である。

（8）ノンホルマリン型である.

（9）アニオン性およびカチオン性の両タイプがある.

SC-シリーズの硬化特性の一例を図1, 図 2 に示 す. 塗料用の SC-106 例にとり，フィルムの吸水率 を硬化度の尺度とした。

衰 1

\begin{tabular}{|c|c|c|c|c|}
\hline & SC-92 & SC-106 & SC-107 & SC-150-7 \\
\hline 不揮発分 (\%) & 33.4 & 33.9 & 33.9 & 51.6 \\
\hline 粘 度(cps) & 20 & 18 & 15 & 360 \\
\hline $\mathrm{pH}$ & 7.8 & 8.0 & 4.6 & 7.5 \\
\hline イオン性 & アニオン & アニオシ & カチオン & アニオン \\
\hline 最低造膜温度 $\left({ }^{\circ} \mathrm{C}\right)$ & $0>$ & 3 & 4 & $0>$ \\
\hline $\begin{array}{l}\text { プル物性 }\left(23^{\circ} \mathrm{C}\right) \\
\text { 破断強度 }\left(\mathrm{kg} / \mathrm{cm}^{2}\right) \\
\end{array}$ & 47 & 110 & 106 & - \\
\hline 伸び率(\%) & 360 & 150 & 200 & - \\
\hline 昅水率 $(\%)$ & 3.2 & 4.0 & 2.5 & - \\
\hline (用黄，考特徵) & 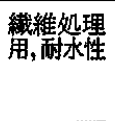 & 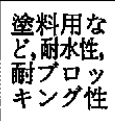 & 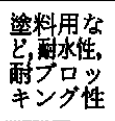 & 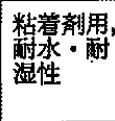 \\
\hline
\end{tabular}
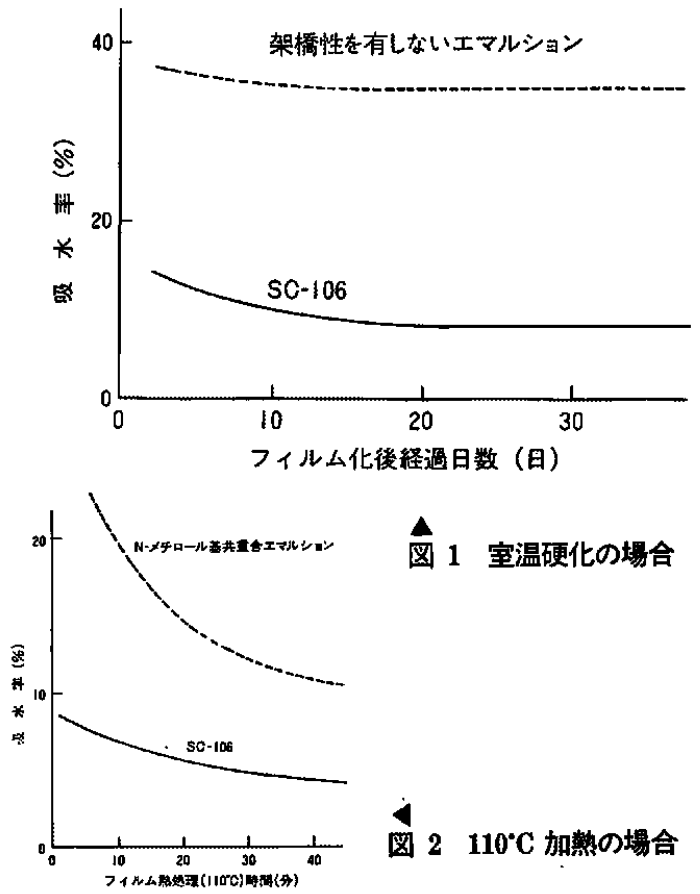

図 1 室温硬化の場合

图 $2110^{\circ} \mathrm{C}$ 加熱の塄合

\section{3. 用途}

表 1, 表 2 に SC-シリーズ各タイプの物性を示す

表 2

\begin{tabular}{|c|c|c|c|c|}
\hline & SC-309 & SC-313 & SC-548 & SC-564 \\
\hline 不掸発分 (\%) & 49.0 & 49.5 & 30.6 & 48.8 \\
\hline 粘 度 (cps) & 4,800 & 320 & 25 & 4,100 \\
\hline $\mathrm{pH}$ & 8.6 & 8.5 & 5.4 & 6.9 \\
\hline イオン性 & Pニオン & アニオン & $P=オ ン$ & Pニオン \\
\hline 最低造膜温度 $\left({ }^{\circ} \mathrm{C}\right)$ & 5 & 1 & - & 10 \\
\hline $\begin{array}{l}\text { ᄀ伀物性 }\left(23^{\circ} \mathrm{C}\right) \\
\text { 破断強度 }\left(\mathrm{kg} / \mathrm{cm}^{2}\right)\end{array}$ & 100 & 110 & - & - \\
\hline 伸び率(\%) & 250 & 250 & - & - \\
\hline 吸水率 (\%) & 10.7 & 6.2 & - & - \\
\hline （用迺，素徽） & 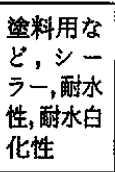 & 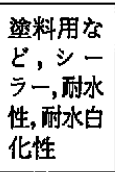 & 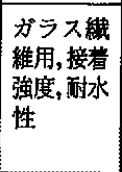 & 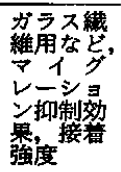 \\
\hline
\end{tabular}

541 大阪市中央区高麗橋 4-1-1 (興銀ビル)

- 06-223-9238 FAX 06-202-1765 


\section{デュアルプレート処理システム“コニカ得得くん”}

\section{コニカ PS 版現像処理システム}

\section{1. 技術の背景}

市場で最も一般的に使用されている PS 版の現像処 理システムは, 繰り返し使用される現像液を用いた自 動現像機によるものであり，こうした方式では現像液 において，PS 版処理㧈よび経時による疲労が伴うた め, 多量の PS 版を安定に処理するには現像液の補充 が必要である. しかし, PS 版の補充現像処理システ ムにおいては,補充の精度や調整の問題, PS 版の品種 対応の問題，およびポジ型 PS 版とネガ型 PS 版を同 時に処理できないなど，いくつかの欠点を有してい る.こうした面倒な補充なしに多品種の PS 版を安定 に，しかも液交換なしにポジ・ネガ両タイプ PS 版を 同時に処理できる現像処理システムが久しく望まれて いた.コニカはこうしたニーズに応えるものとして， 新規な技術を採用した新しい処理システムを開発し た.

\section{2. システムの特長}

（1）常にフレッシュ現像

常にフレッシュな現像液で処理するため, 高安定 な現像処理性が得られる。

(2) 新現像方式

塗布現像＋浸漬現像により最少必要量の現像液で 高品筫の仕上りが得られる.

（3）ポジ・ネガ共通処理

同一自動現像機，同一現像液でポジ型 PS 版，ネ ガ型 PS 版とも処理できる.

（4）現像液補充システム不要

現像液補充システムが不要になるため，わずらわ しい現像液感度コントロール作業がなくなる。

（5）迅速処理

Dry to Dry 60 秒という迅速処理ができるため, 菊全版がわずか 80 秒で処理完了.

（6）自動ミキシング

現像液は自動ミキシングにより調合されるため, 作業は濃縮現像液カートンをセットするだけ，希 釈作業の手間が省ける。

\section{3. システム構成}

本システムは, コニカポジ型 PS 版,ネガ型 PS 版, 自動現像機 (PSU シリーズ) および現像液 (ポ ジ・ネガ共通現像液 SD-32, ポジ専用現像液 SDP-12) から構成されている. PS 版としては, 従来のものが そのまま使用でき, 現像液は本システム専用となって いる. 自動現像機は，新液塗布現像方式が採用されて

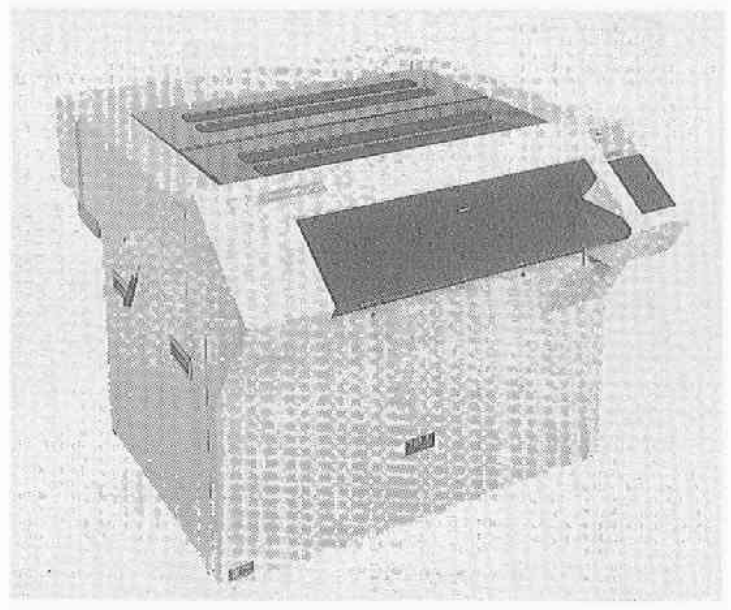

おり, 高安定な現像が行われ, 後処理工程について は, プレリンス方式の採用により, 水洗フリーで安定 性のある刷版処理で再現されるようになっている。

4. 自動現像機の仕様

$$
\text { PSU-820 }
$$

PSU-1315

型

式：ローラー搬送方式

塗布一漫漬一回転ブラシによるコスリ現

像，プレリンス方式

現象版材: コニカオフセットPS 版ポジタイプ・ネ ガタイプ (一部使用不適の品種有)

処 理 版：最大幅 $820 \mathrm{~mm}$

サイ ス 最小幅 $300 \mathrm{~mm}$ 最小幅 $300 \mathrm{~mm}$ 最小長 $450 \mathrm{~mm}$ 最小長 $450 \mathrm{~mm}$ 処 理 時 間 : 20 秒 $/ 30$ 秒 $/ 40$ 秒 (3 段切替)

搬送速度: $990 \mathrm{~mm} \sim 495 \mathrm{~mm} /$ 分 $1530 \mathrm{~mm} \sim 765 \mathrm{~mm} /$ 分 処 理 能力: 現像20秒, 54 版/時 現像 20 秒, 78版/時 (1003×800mmサイズ) (1050×1310mmサイズ) 現像液自動：内藏 内藏

ミキシング装置

現 像 液: SD-32（ポジ・ネガ共用）

SDP-12（ポジ専用）

ドライヤー：標準装備＼cjkstart標準装備

\section{コニカ (株)}

印刷産商販売事業部

本社

恶 163 東京都新宿区西新宿 1-26-2（新宿野村ビル） : 03-349-5155 


\section{エラスロン}

\section{フレキソ印刷用感光性樹脂}

\section{1. 技術の背景}

東京応化の感光性樹脂版は昭和 49 年にナイロン系 感光性樹脂版「トプロン」を開発し, 以来水溶性感光 性樹脂版「ミラクロン」「リジロン」, フレキソ用感光 性樹脂版「エラスロン」を商品化してきた，東京応化 は長年培ったこれらの知識をべースに新たに改良した 「エラスロン」について紹介する。

フレキソ印刷は，わが国では段ボール印刷が主な用 途であり，欧米においては段ボール印刷と軟包装印刷 とが主な用途である，今後段ボール印刷においては， 商品イメージアップのための美粧化，大型化の要求， 物流バーコードの普及などの問題, 一方, 軟包装印刷 においても印刷再現性の向上, 刷版コストの低減など の要求があり, 印材である感光性樹脂版についてもよ りいっそうの改良が要求される。このような要求を満 たすべく新たに改良した「エラスロン」の期待は大き いものと考えられる.

\section{2. 構造}

「エラスロン」は合成ゴムを主体とした感光性樹脂 版（感光波長域：300 400 nm）であり, 版の構造 は, 保護カパーフィルム, スリップコート層（品種に よっては無し), 感光性樹脂層, ベースフィルム（ま たは保護かパーフィルム) から成っている, 版の厚み は 1 7.5 mm まで, 版サイズは最大 $841 \times 2,400 \mathrm{~mm}$ まで，版の硬度は $30^{\circ} \sim 50^{\circ}$ （ショアーA）まで揃えて おり，印刷ニーズにきめ細かな対応を行うことができ る.

\section{3. 特徵}

1）解像性，露光ラチチュードが優れている.

求められるデザインは，ますます多様化していく が，どのようなデザインにも対応しやすくなる．

2) 版厚精度が高い.

版厚精度は $\pm 2 / 100 \mathrm{~mm}$ 以内であり, 軽い印圧でも 鮮明な印刷上がりとなる。

3）反発弾性の向上.

反発弾性の向上により印圧レンジを広くとることが でき，また高速印刷にも十分対応できる。

4）インキ受理性, 転位性の向上.

インキ受理性，転位性を向上させたので，印刷品質 は格段に向上する.

5）経日変化が少ない。

長期保存した場合の版の劣化およびカールが少なく 長期間の置版が可能となる.

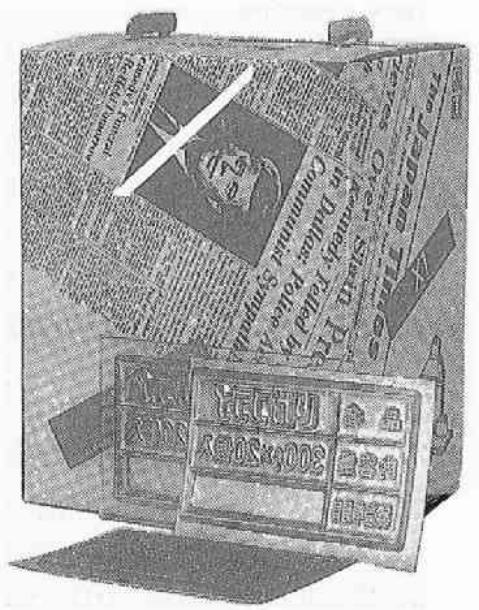

東京応化「エラスロン」

6）露光後のパターン確認ができる.

主露光後, 露光部と非露光部との濃度差があり, 現 像前にパターンを肉眼で確認できるので, 二重露光な どのトラブルがなくなる。

7）新しい製版方法の開発.

「エラスロン」のベース品は露光後イメージを確認 できるので，その囲りに專用カッターで切り込みを入 れ未露光部をべースから㥗ぎ取ったのち現像処理で き，作業の合理化が図れる。

4. 弚の他

東京応化は凸版印刷(リジロン，ミラクロン，テピ スタ他), 新聞印刷(リジロン他), フレキソ印刷(エラ スロン他)，スクリーン印刷(スーパーキング，オーカ スター他), グラピア印刷 (TPR, PMER), 平版印刷 (TOK・PS プレート), 特殊印刷分野の印刷版材のす ぺてを網羅しており，印刷版材の総合メーカーとして 印刷業界に貢献してゆく所存である。

\section{東京応化工業（株）}

営業二部印刷材料課

②11 川崎市中原区小杉町 1-403

8 044-722-9571 FAX 044-733-7984 


\section{フォテック ${ }^{\circledR}$ (PHOTEC)}

感光性フィルム

\section{1. 技術の背暴と市場動向}

電算機，電子通信機などの産業用機器をはじめ，テ レビ, カメラ, 腕時計, ビデオカメラ, 卓上計算機な どの民生用機器にも電子部品の電気的接続のため, プ リント配線板 (以下，PWB と略す) が多用されてい る. 感光性フィルム“フォテック®” 線パターンを形成する際のエッチングレジストあるい はめっきレジストとして使用されている，また，部品 を搭載する際のはんだレジストとして用いられる永久 マスクタイプのフィルムもある。

最近, 機器の高性能化, 小形化に伴い, PWB は高 密度化, 高精度化が図られておう, 感光性フィルムに 対しても高解像度, 高密着性および高作業性などが要 求されている．日立化成工業(株) ではこれらの要求 に応える各種感光性フィルムを昭和 50 年から製品化 している。

\section{2. 構成と用途および特性}

“フォテック”㤝図に示すように，ベースフィル ム, 感光層, 保護フィルムの三層から成り, 所定幅で ロール状に巻いたものである.

“フォテック”の用途と特性を表に示す。

\section{3. 特 長}

（1）配線パターン形成用フィルムは次に示す特長を有 する。

(1) 短時間の露光で精密なパターンが得られる.

(2) 膜強度に優れ，しかも密着性が良いのでテント （スルホールの保護）信頼性が向上する。

(3) 露光により濃青緑色に変色するので露光作業の 管理が容易である。

(4) 耐薬品性に優れている.

(5) 作業幅の裕度が広い。

（2）永久マスクフィルムは次に示す特長を有する。

(1) 写真法で像形成するため, 精密な画像が得られ る.

(2) はんだ雨熱性，耐溶郕性，電気絶縁性に優れて いる.

(3) 密着性および熱流動性に優れているので, 基板 の山凸面を均一な厚さに被蕧できる。

(4) UL94V-O の認定（No. E79926）を取得してい る.

表に示す製品はすべてアルカリ水溶液で現像でき， 有機溶隹を使用しないので，作業環境を簡便に管理す ることができるとともに，ランニングコストを下げる

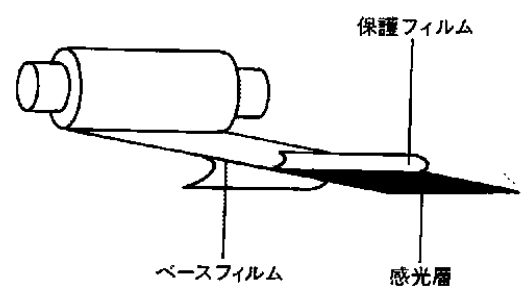

図 フォテックの構成

害 “フォテック®” の用途・特性

\begin{tabular}{|c|c|c|c|}
\hline 品 名 & パターン形 & 用フィルム & $\begin{array}{l}\text { 永久マスク } \\
\text { フィルム }\end{array}$ \\
\hline 項 目 & $\mathrm{H}-\mathrm{S} 250$ & $\mathrm{H}-\mathrm{F} 240$ & SR-2300G-75 \\
\hline 用 & $\begin{array}{l}\text { エッチングレ } \\
\text { ジスト(デン } \\
\text { ティング) }\end{array}$ & $\begin{array}{l}\text { エッチングレ } \\
\text { ジスト } \\
\text { めっきレシスト }\end{array}$ & はんだシスト \\
\hline 感光層愿さ $(\mu \mathrm{m})$ & 50 & 40 & 75 \\
\hline $\begin{array}{c}\text { 現像条件 } \\
\mathrm{Na}_{2} \mathrm{CO}_{3} \text { aq.滣度 }(\%) \\
n \text { 温度 }\left({ }^{\circ} \mathrm{C}\right) \\
\text { 最少現像時間(秒) }\end{array}$ & $\begin{array}{c}1.0 \pm 0.3 \\
30 \pm 2 \\
40\end{array}$ & $\begin{array}{c}1.0 \pm 0.3 \\
30 \pm 2 \\
35\end{array}$ & $\begin{array}{c}1.0 \pm 0.3 \\
32 \pm 2 \\
75\end{array}$ \\
\hline $\begin{array}{l}\text { 感光特性 } \\
\text { 感 度 }\left(\mathrm{mJ} / \mathrm{cm}^{2}\right) \\
\text { 解像度 }(\mu \mathrm{m}) \\
\text { 密着性 }(\mu \mathrm{m})\end{array}$ & $\begin{array}{l}50 \\
70 \\
60\end{array}$ & $\begin{array}{l}60 \\
60 \\
60\end{array}$ & $\begin{array}{r}200 \\
125 \\
80\end{array}$ \\
\hline $\begin{array}{l}\text { イメージング性* } \\
(\Delta E)\end{array}$ & 35 & 9 & - \\
\hline $\begin{array}{l}\text { はんた耐熱性 } \\
\left(260^{\circ} \mathrm{C}-10 \text { 秒 }\right)\end{array}$ & - & - & 3 回 $\mathrm{OK}$ \\
\hline
\end{tabular}

*露光部と末簿光部の色差

ことができる。

\section{4. 将来動向}

今後，PWB はますます配線の微細化，高密度化が 進むとともに, PWB の生産性向上，コスト低減，製 造プロセスの自動化が図られていくものと思われる。

これに伴い，顧客で使用しやすい感光性フィルムが 必要となり，諸特性の向上が必要である。

日立化成工業(怢) では，これらの要求に応えるた め, 各用途別に, 製造プロセスに合った感光性フィル ムの開発を積極的に進めている。

\section{日立化成工業（株）}

山崎工場

317 日立市東町 4-13-1

20294-22-5111 FAX 0294-21-0487 


\section{TUFFY ${ }^{\circledR}$}

\section{防湿絶縁塗料}

日立化成工業(株)では，1980 年以来，実装回路板 およびハイブリッド IC の保護コーティングを目的と

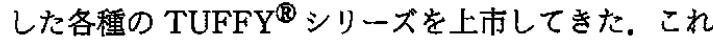
らは実装回路板およU゙ハイブリッド IC の信頼性向上 に効果があることが認められ，多岐にわたる用途の各 種実装回路板およびハイブリット゚ IC に採用されてい

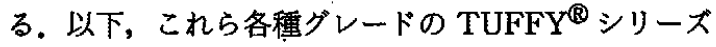
の特性を紹介する。

\section{TUFFY ${ }^{\circledR}$ シリーズの特性}

TUFFY $^{\circledR}$ シリーズの特長扔よび用途を表 1 に，特 性を表 2 に示す。

表 1,2 に示すような各種の TUFFY இシリーズは, それぞれの特徴に応じて，産業の広い分野の各種実装 回路板抢よびハイブリッド IC 用の保護コーティング 材料として使用されている.今後, 機器の実装密度の 高度化と高信頼性の要求がますます強く求められてい

表 1 TUFFY@ シリーズの特長および用途

\begin{tabular}{|c|c|c|c|}
\hline 対 象 & 品 名。 & 特 & 用 \\
\hline \multirow{5}{*}{ 䒠㸵路板 } & TF-1141 & 常乾タイプ,一液,軟質の沉用夕 & 電装用基板他 \\
\hline & TF-1147 & 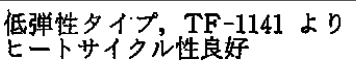 & 電装用基板他 \\
\hline & TF-1141T & $\begin{array}{l}\text { TF-1141 の厘膜タイプ. } \\
\text { 而湿性良好 }\end{array}$ & 工作機器他 \\
\hline & TF-5100 & 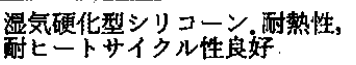 & 電装用基板他 \\
\hline & TF-7100* & $\begin{array}{l}\text { 2液のウレタン系注型タイプ. } \\
\text { 耐湿性良好 }\end{array}$ & 洗濯機他 \\
\hline \multirow{2}{*}{$\begin{array}{l}\text { ハイブ } \\
\text { リッ }\end{array}$} & $\begin{array}{l}\mathrm{TF}- \\
3340 \mathrm{~K}-2\end{array}$ & 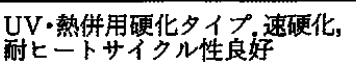 & VTR 他 \\
\hline & HIT- 8000 & 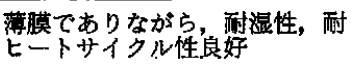 & 交換機他 \\
\hline
\end{tabular}

*TF.7100 以外はすべて䇠料タイプ るが, TUFFY® シリーズはこのような市場ニーズに 十分貢献できるものと確信している。

衰 2 TUFFY®シリーズの特性の一例

\begin{tabular}{|c|c|c|c|c|c|c|c|}
\hline 特 性 項 目 & $\mathrm{TF}-1141$ & TF-1147 & $\mathrm{TF}-1141 \mathrm{~T}$ & $\mathrm{TF}-5100$ & $\mathrm{TF}-7100$ & $\mathrm{TF}-3340 \mathrm{~K}-2$ & HIT- 8000 \\
\hline $\begin{array}{l}\text { 液状特性 } \\
\text { 樹脂のタイプ } \\
\text { 粘 度 }\left(25^{\circ} \mathrm{C}, \mathrm{Pa} \cdot \mathrm{S}\right) \\
\text { 不揮発分 }(\%) \\
\text { 指触乾㷥時間 }\left({ }^{\circ} \mathrm{C} / \text { 分 }\right)\end{array}$ & $\begin{array}{c}\text { アクリル } \\
0.17 \\
36 \\
23 / 6\end{array}$ & $\begin{array}{c}\text { アクリル } \\
0.18 \\
36 \\
23 / 7\end{array}$ & $\begin{array}{c}\text { アクリル } \\
2.1 \\
39 \\
23 / 15\end{array}$ & $\begin{array}{c}\text { シリコーン } \\
1.1 \\
70 \\
23 / 45\end{array}$ & $\begin{array}{c}2 \text { 液ウレタン } \\
1.5^{* 1} \\
- \\
-\end{array}$ & $\begin{array}{c}\text { 特殊アクリル } \\
0.04 \\
37 \\
\mathrm{UV}^{* 2} / 1.5\end{array}$ & $\begin{array}{c}\text { エポキシ } \\
0.4 \\
43 \\
120 / 10\end{array}$ \\
\hline $\begin{array}{l}\text { 硬化膜の特性. } \\
\text { 可とう性 (マンドレル径mm) } \\
\text { 鉛筆硬度 } \\
\text { 絸弾性係数 }\left(25^{\circ} \mathrm{C}, \mathrm{N} / \mathrm{mm}^{2}\right) \\
\text { 体積抵抗率 }\left(25^{\circ} \mathrm{C}, \Omega-\mathrm{cm}\right) \\
\text { 比誘電率 }\left(25^{\circ} \mathrm{C}, 50 \mathrm{~Hz}\right)\end{array}$ & $\begin{array}{c}2 \\
3 \mathrm{~B} \\
980 \\
4 \times 10^{15} \\
2.8\end{array}$ & $\begin{array}{c}2 \\
4 \mathrm{~B} \\
10 \\
3 \times 10^{15} \\
2.5\end{array}$ & $\begin{array}{c}2 \\
3 \mathrm{~B} \\
980 \\
2 \times 10^{15} \\
2.8\end{array}$ & $\begin{array}{c}2 \\
<6 \mathrm{~B} \\
36 \\
2 \times 10^{15} \\
2.7\end{array}$ & $\begin{array}{c}\frac{2}{-} \\
1 \times 10^{13} \\
5.3\end{array}$ & 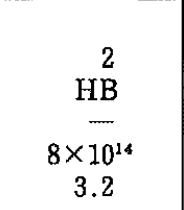 & $\begin{array}{c}\frac{2}{4 \mathrm{H}} \\
\frac{-}{3 \times 10^{15}} \\
3.3\end{array}$ \\
\hline 硬化条件の一例 $\left({ }^{\circ} \mathrm{C} /\right.$ 分 $)$ & $50 / 15$ & $50 / 15$ & $50 / 120$ & $50 / 60$ & $80 / 30$ & $\begin{array}{l}U_{\text {は }}{ }^{* 2} / 30 / 60 \\
\text { また }\end{array}$ & $\begin{array}{l}120 / 60 \\
+150 / 90\end{array}$ \\
\hline
\end{tabular}

${ }^{* 1} \mathrm{~A}$ 液, B 液配合後 $25^{\circ} \mathrm{C} 3$ 分後の粘度 ${ }^{* 2} \mathrm{UV}$ は $30 \mathrm{~mW} / \mathrm{cm}^{2}$ で察囲気温度 $150^{\circ} \mathrm{C}$

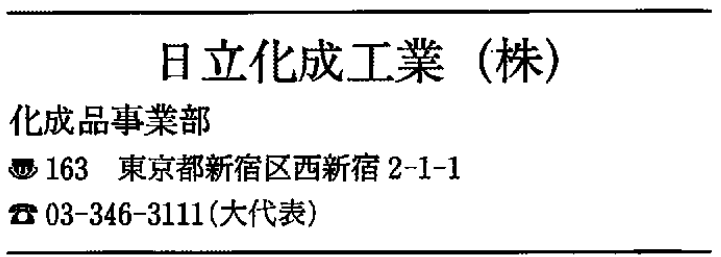




\section{Adwill $^{\circledR}$-アドウィルシステム}

\section{1. はじめに}

FSK のキーテクノロジーは, 精密 コーティング技術, 粘接着技術, 高分 子材料加工技術ならびにメカトロニク スを駆使してそれらをシステム化する “テープトロニクス”にある。ここに 揭げる Adwill ${ }^{\circledR}$ システムはまさにテ ープトロニクスの所産で, 高機能性テ 一プ群と精密機械群から構成される. 指数関数的に增大する集積度は遈か らずギガビットとなる，その時代に対 処すべく Adwill テープは超クリー ンルーム（米国連邦規格クラス 100) 内で一貫生産されている。 また精密機 械群の設計理念怆, 半導体組立工程の高度ファクトリ ーオートメーション (FA) 化を達成させることにあ る. ソフト\&ハードのシナジー効果により Adwill ${ }^{\circledR}$ システムはさらなる飛躍を遂げるものと予測される。

\section{2. 整品群（図 1)}

Adwill システムは，1）完成ウェハのバックグラ インディング工程，2）テップ化するダイシング工程, 3）モールド製品のパッケージング工程に適応される.

\section{3. 特長}

主力製品について概要を示す.

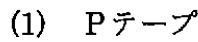

粘着剂，金属イオンなどの污染を最少限にした回路 保護用テープでウェ八面にレジストをコートせずに直 接貼付することができる.万一回路面に残存しても純 水洗浄で除去できる粘着片ゆえに，有害なトリクレン 洗浄が不要となった。

(2) RAD-3100 \& 3200

ウェハサイズに合わせたラベル状テープを供給する 方式のため装置内のテープカットが不要で，ウェ八に 負荷がかからない（前者)。バキュームステージでウ エハを全面吸着し強粘着テープでPテープを剝離する 方式で，薄いウェハ $\left(300 \mu \mathrm{m} / 6^{\prime \prime}\right)$ でも破損すること なく連続作業が行える(後者).

両機種とも 100 故/時間の処理能力を有している.

(3) Dテープ (図 2)

アクリル系ポリマーに特定の分子量分布を有する UV 硬化型オリゴマーがフォーミュレートされた粘着 剤である，ダイシング時には強い接着力で確実にチッ プを保持し，ダイボンディングの際は UV 照射によ
Adwill ${ }^{\mathbb{S}}$ System

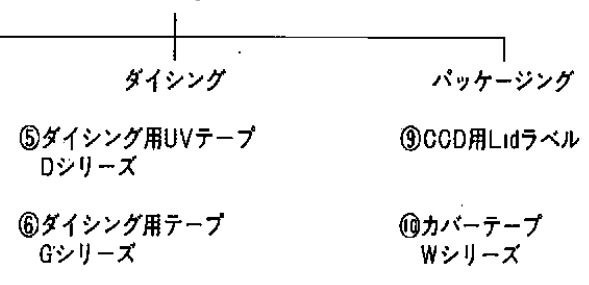

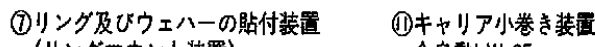
(リングマウント装霟) 全自動 全自勤RAD-2580

(8)UV装置 全自動FAD-2000 全自動RAD-1000
図 2 (工程]

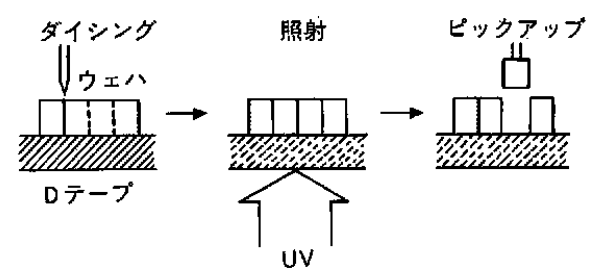

〔接着力〕 テープ UV照射前 UV照射後

D- $105 \quad 210 \mathrm{~g} / 25 \mathrm{~mm} \quad 25 \mathrm{~g} / 25 \mathrm{~mm}$ D- $203 \quad 2400 \mathrm{~g} / 25 \mathrm{~mm} \quad 30 \mathrm{~g} / 25 \mathrm{~mm}$ D-606 $100 \mathrm{~g} / 25 \mathrm{~mm} \quad 30 \mathrm{~g} / 25 \mathrm{~mm}$

り所望の弱い接着力を示すュニークなダイシングテー プである。

(4) RAD-2500

回路面非接触方式でウェハにダイシングテープを貼 る装置である（フラットフレームも枚葉でテーピング される).ウェハのバーコード管理システムや光学ア ライメント機能を備えた高度 FA 型装置で，100枚/ 時間の処理能力を誇る。

\section{FSK (株)}

(m) 173 東京都板橋区本町 23-23

本社市場開発部

203-579-6111（代）

画 335 埼玉県硔市錦町 5-14-42

研究本部研究所

จ 0484-43-6171

FAX 0484-41-6110 


\section{PSI-Nシリーズ(多層配線層間絶縁用シロキサン变性ポリイミドワニス)}

\section{シロキサン変性ポリイミドワニス}

\section{1. 技術の背景}

LSI の高密度, 高集積化に伴い, 多層配線技術が必 須となってきている. 現状では, プラズマCVDによ り形成される窒化ケイ素膜あるいは酸化ケイ素膜など の無機膜が使われている.しかし, これらの膜では平 坦化および内部応力の緩和が難しいため多層化が困難 であるといわれている. 平坦化を実現するためにエチ ルシリケートオリゴマー塗布液 (SOG とよばれる) が検討されてきたが，厚膜化ができないことおよび焼 成温度が高過ざることなど問題が多い, 無機材料の欠 点を補なうものとして熱的, 機械的, 電気的性質が優 れている全芳香族ポリイミドが検討されたが，無機材 料との密着性が不十分であるなどの欠点を有してい る. 密着性を改良するためポリマー構造中にジメチル シロキサン成分を組み込んだポリイミドも検討された が, 而熱性が低下しこの用途には適さない.

このような状況に鑑み, 弊社と日本電気(株) 超 LSI 開発本部が共同研究を行い, 上記欠点を改良するとと もに新たな長所をも付加した層間絶緑膜用シリコンポ リイミドワニス, PSI-N シリーズを開発した.

2. 特性

○ワニスの特性

\begin{tabular}{|c|c|}
\hline 溶 & $N, N$-ジメチルアセトアミド \\
\hline 固 形 分 漕 度 & $20 \sim 30$ wt $\%$ \\
\hline 度 & $100 \sim 300$ CPS \\
\hline 厚 & $1 \sim 2 \mu \mathrm{m}$ \\
\hline ガードナー色数 & 10 以下 \\
\hline 過 & $0.2 \mu \mathrm{m}$ \\
\hline
\end{tabular}

○膜特性

\begin{tabular}{|c|c|c|}
\hline 機械特性 & $\begin{array}{cccc}\text { 引 } & \text { 張 } & \text { 強 } & \text { 度 } \\
\text { 引 } & \text { 張 } & \text { 伸 } & \text { 度 } \\
\text { 密 } & & & \text { 度 }\end{array}$ & $\begin{array}{l}5.6 \mathrm{kgf} / \mathrm{mm}^{2} \\
0.4 \% \\
1.40 \mathrm{~g} / \mathrm{cm}^{3}\end{array}$ \\
\hline 熱 特 性 & $\begin{array}{lrr}\text { 融 } & \text { 点 } \\
\text { 燃 焼 性 } \\
\text { 熱 膨 張 係 数 } \\
\text { ガラス転移点 }\end{array}$ & $\begin{array}{c}\text { な し } \\
\text { 自己消火性 } \\
4 \times 10^{-5} /{ }^{\circ} \mathrm{C} \\
\left(25^{\circ} \mathrm{C} \sim 450^{\circ} \mathrm{C}\right) \\
\text { な し }\end{array}$ \\
\hline 電気特性 & $\begin{array}{l}\text { 比 誘 電 率 } \\
\text { 誘 電 正 接 } \\
\text { 体 積 抵 抗 率 } \\
\text { 表 面 抵 抗 } \\
\text { 絶縁破壞電界強度 }\end{array}$ & $\begin{array}{l}3.2(1 \mathrm{MHz}) \\
0.003 \\
3 \times 10^{16} \Omega \\
1 \times 10^{15} \Omega \\
3 \mathrm{MV} / \mathrm{cm}\end{array}$ \\
\hline
\end{tabular}

高分子 38 巻 6 月号堌刊 (1989 年)

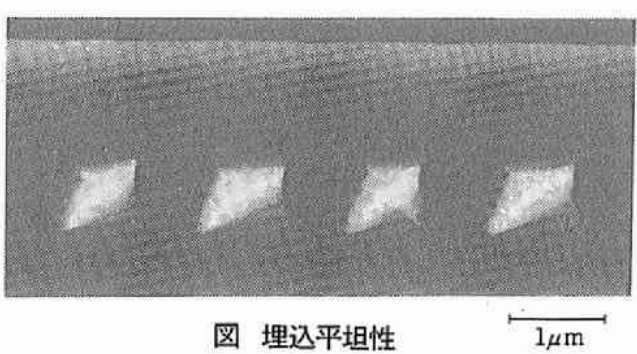

\section{3. 特徵および用途}

OPSI-N シリーズの特徵

分子構造: ポリイミド連鎖に $\mathrm{SiO}$ 成分が化学的に 結合している.

耐 熱 性: 熱処理後の膜は従来の全芳香族ポリイミ ドと同等の耐熱性を有している。

熱膨張特性： $25 \sim 450^{\circ} \mathrm{C}$ 温度範囲で, 直線的に変化 する. 従来の芳香族ポリイミドにみられ るガラス転移点はない。

接 着 性：金属膜, 無機膜と優れた接着性を有して いる.

埋込平坦性：サプミクロン配線間を完全に埋込み，か つ, 平坦性に優れている (図).

不純物 量: アルカリ金属などの不純物は, 極微量で ある.ウラントリウムなどの放射性元素 は $1 \mathrm{ppb}$ 以下である.

電気特性: 絶縁特性に優れている. 特に高温 $\left(200^{\circ} \mathrm{C}\right)$ におけるリーク電流が小さい.

OPSI-N シリーズの用途

PSI-N シリーズは高接着性, 高耐熱性を有し, 高 信頼性の膜形成を可能にし, 優れた熱特性, 電気特性 も有しており, 特に, IC, LSI, 超 LSI の多層配線層 間絶縁膜に適しています さらに, 他の電子部品など にも十分使用可能です.

\section{参考文献}

○本間他:「シロキサン変成ポリイミド膜による平坦化技 術」月刊 Semiconductor World (1988.8) p.37

○本間他: 「多層配線用新ポリイミド膜」月刊電子材料 (1988. 12) p.46

\section{チッソ（株）}

開発室

(100 東京都千代田区丸の内 2-7-3

20 03-284-8505 FAX 03-284-8486 


\section{パラリンクス TS}

\section{メタクリル樹脂}

\section{1. 技術背景}

パラリンクス TS は, 協和ガス化学が独自の技術に より開発した耐熱性と耐溶剂性の優れたメタクリル樹 脂板です，通常の熱可塑性のメタクリル樹脂板とは異 なり，分子間に架橋構造を導入することで,メタクリ ル樹脂に特有の光学的性質や耐候性などの優れた特性 をまったく損なわずに，前記の特性の向上を実現しま した.

パラリンクス TS は, 熱変形温度が高い銘柄ほど, 各種溶剤に対してより大きな最小ヒビ割れ応力值を示 します、溶剂や応力によるクレーズの発生が間題とな る用途など，これまで通常のメタクリル樹脂板の使用 が困難だった用途にもメタクリル樹脂板の利用が可能 になりました。

\section{2. パラリンクス TS の特徵}

（1）超耐熱性であること.

熱変形温度が, 最高 $140^{\circ} \mathrm{C}$ 製品まで, 取りそろ えています。

（2）耐薬品性が優れていること.

通常の有機溶剤に溶解せず，優れた而七ビ割れ性 を示します。また多くの無機酸に対しても優れた 耐性を示します。

（3）透明性が優れていること.

室温だけでなく高温でもへイズが発生せず優れた 透明性を示します。

（4）耐候性が優れていること.

（5）スチーム滅菌処理が可能であること.

（6）その他，多くの性能が通常メタクリル樹脂板と同 水準にあります。

3. 物性

パラリンクス TSの基本物性を表 1 に示す. 図 1 に は，各種溶剤に対する最小ヒビ割れ応力を示す。

4. 用途

(1) 自動車用途 サンルーフ，サンバイザーメーターカバーなど

（2）電気㹈品用途 照明カパー, 電子レンジ前面板など

（3）工業用部品用途 機械カバー，銘板，厨屏温蔵庫の窓など

（4）建材用途

サウナ室空, サンルーム, 浴室の空など

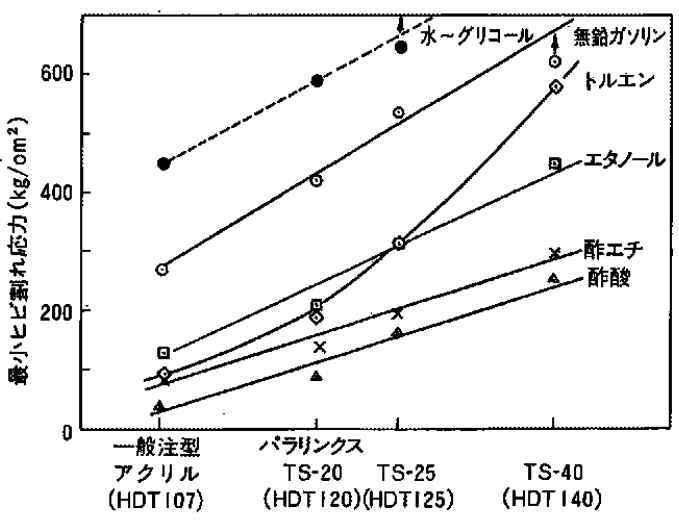

図 1 パラリンクスの各璉溶㓮に対する最小ヒビ割れ 応力 (at R.T)

衰 1 パラリンクス TS の基本物性

\begin{tabular}{|c|c|c|c|c|}
\hline 銘 柄 & TS-20 & TS-25 & TS-40 & 対照"1 \\
\hline $\begin{array}{l}\text { 熱変形温度 } \\
\end{array}$ & 120 & 125 & 140 & 107 \\
\hline $\begin{array}{l}\text { 線膨張 率 } \\
\left(1 /{ }^{\circ} \mathrm{C}\right)\end{array}$ & $7 \times 10^{-5}$ & $7 \times 10^{-5}$ & $7 \times 10^{-5}$ & $7 \times 10^{-5}$ \\
\hline $\begin{array}{c}\text { 引張強 度 } \\
\left(\mathrm{kg} / \mathrm{cm}^{2}\right)\end{array}$ & 800 & 820 & .710 & 780 \\
\hline $\begin{array}{c}\text { 引張伸び率 } \\
\end{array}$ & 6.0 & 6.0 & 4.0 & 6.0 \\
\hline $\begin{array}{l}\text { 引張弾性率 } \\
\left(\mathrm{kg} / \mathrm{cm}^{2}\right) \\
\end{array}$ & $3.3 \times 10^{4}$ & $3.3 \times 10^{4}$ & $3.3 \times 10^{4}$ & $3.3 \times 10^{4}$ \\
\hline 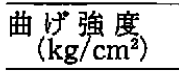 & 1,250 & 1,250 & 1,200 & 1,200 \\
\hline $\begin{array}{l}\text { 曲げ弾性率 } \\
\left(\mathrm{gg} / \mathrm{cm}^{2}\right)\end{array}$ & $3.3 \times 10^{4}$ & $3.3 \times 10^{4}$ & $3.3 \times 10^{4}$ & $3.3 \times 10^{4}$ \\
\hline 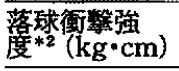 & 46 & 63 & 36 & 38 \\
\hline $\begin{array}{l}\text { 至光線涹過 } \\
\text { (\%) }\end{array}$ & 93 & 93 & 93 & 93 \\
\hline ヘイズ (\%) & 0.3 & 0.3 & 0.3 & 0.3 \\
\hline
\end{tabular}

*1一般注型メタクリル樹脂板, *2. 板厚 $3 \mathrm{~mm},{ }^{* 3}$ 板 厚 $3 \mathrm{~mm}$

\section{協和ガス化学工業 (株)}

画 104 東京都中央区八丁堀 2-9-1 秀和東八重洲ビル co3-297-9425
FAX 03-297-9418 


\section{光ディスク用非球面プラスチックレンズ}

\section{アクリル系樹脂}

1. はじめに

当社は，1984年 6 月，CD（コンパクトディスク） 用対物レンズとして，アクリル系樹脂を使った高精度 単玉非球面プラスチックレンズの開発・量産化に成功 した。 それを契機として，その後，非球面そールドガ ラスレンズ, 屈折率分布型レンズ, グレーティングレ ンズなどが開発されているが，現在利用されている $\mathrm{CD}$ 用対物レンズの $80 \%$ 以上が非球面プラスチック レンズであり，他のディスクシステムの分野にも，そ のピックアップ用対物レンズとして非球面プラスチッ クレンズが利用されはじめている。本稿では光ディス ク用非球面プラスチックレンズの最近の状況をプラス チック素材の改良と対応させながら紹介したい.

2. 光ディスク用非球面プラスチックレンス

非球面プラスチックレンズは，1）性能が複数枚構 成の球面ガラスレンズよりも優れている，2）軽量で ある $(0.07 \mathrm{~g} \sim 0.13 \mathrm{~g}) ， 3)$ 大量生産時には低コス卜 でできる，4）環境温湿度による焦点位置変化はピッ クアップのオートフォーカス機構により問題とならな い，などの特長を有している.

\section{3. 素材の選定}

レンズ用菜材として特に重要なパラメーターは，涌 熱性，耐湿性，内部歪みが小さいことなどがあげられ る。光ディスク用対物レンズとして使う場合, 回折限 界までの結像性能が要求されるため, 内部歪みの小さ いこと蚌常に重要であるアアクリル系樹脂はその内 部歪みが小さく，光ディスク用対物レンズとしてはふ さわしい素材である。

\section{4. 丵材の改良と用途の拡大}

\section{1 ・高耐㺘性対物レンズ}

プラスチックレンズの耐環境特性（耐熱性，耐湿 性）は素材の改良で著しく向上している，通常の CD 用対物レンズでは， $75^{\circ} \mathrm{C}$ 耐熱保存温度が保証されて いるが，特殊な用途，たとえば車載 CD 用レンズには より高い耐熱保存温度が必要である。1986 年に量産 化にされた車載 CD 用非球面プラスチックレンズはア クリル系耐熱素材が使われており，100年の耐熱保存 温度を有している。

\section{2 高開口数対物レンズ}

光学式 VD (ビデオディスク), DRAW（追記型光 ディスク), 書換え可能型光ディスクには，情報の高 密度再生，記録およびアクセス時間の短縮という要求 がある。したがって対物レンズは，高開口数であるこ

高分子 38 巻 6 月号增刊 (1989 年)
表 1 アクリル系樹脂の物性比較

\begin{tabular}{|c|c|c|c|}
\hline & 通常菜材 & 耐熱菜材 & 耐熱耐湿慈材 \\
\hline 屈 折 率 & 1.49 & 1.51 & 1.50 \\
\hline 熱変形温度 & $100^{\circ} \mathrm{C}$ & $122^{\circ} \mathrm{C}$ & $105^{\circ} \mathrm{C}$ \\
\hline 線膨張係数 & $7 \times 10^{-5} /{ }^{\circ} \mathrm{C}$ & $7 \times 10^{-6} /{ }^{\circ} \mathrm{C}$ & $7 \times 10^{-5} /{ }^{\circ} \mathrm{C}$ \\
\hline 飽和吸水率 & $2.0 \%$ & $1.9 \%$ & $1.1 \%$ \\
\hline 複 屈 折 & 少 & 少 & 少 \\
\hline & $\mathrm{CD}$ 用 & 車載 CD 用 & $\begin{array}{l}\text { 光学式VD 用, } \\
\text { 光メ王りー用, }\end{array}$ \\
\hline
\end{tabular}

と（0.50〜0.55)，軽量であること，また環境温湿度 変化に対する性能変化の許容量も䈆しくなる. 1987 年に量産化された光学式 VD 用対物レンズディスク およびその後開発された DRAW 用, 青換え可能型光 ディスク用対物レンズには吸水率が従来の $1 / 2$, さら に 80〜85Cの環境下でも性能が劣化しないアクリル 系耐熱耐湿素材が用いられている，表 1 にこれら素材 の比較対応を示す.

\section{4. むすび}

$\mathrm{CD}$ 用非球面プラスチックレンズが量産されて以 来, プラスチック菜材の改良とともに光ディスクのあ らゆる分野のレンズがブラスチックレンズで実現され た。 今後市場の成長とともに，市場ニーズにふさわし い小型, 軽量, 高性能な非球面プラスチックレンズが 開発されてゆくであろう。

$$
\text { コニカ (株) }
$$

オプト事業部

(3) 192 東京都八王子市石川町 2970 コニカ八王子工場 ت 0426-42-0161 FAX 0426-44-5212 


\section{スミカライト}

\section{ポリカーボネート系光学用位相差フィルム}

\section{1. 技術の背暴と市場動向}

住友化学は，長年培った高分子合成技術および高分 子加工技術を基盤として，光学的に均一な複㞑折性を 有する光学位相差フィルム, スミカライトを開発し た.このフィルムは, STN 型液晶表示装監の白黒表 示を可能とする要素材料として用いるのに十分な均質 性と耐久性を有し, STN 型液晶表示装置の高品質化 を達成する機能を有する。

最近の液晶表示装置は，ワードプロセッサー, パー ソナルコンピューターなどの普及に応じて, 液晶分子 のねじれ角を 180〜270 度にして大画面化の要請に応 えた STN 型液晶表示装置が開発され，実用化されて いる、しかし，STN 方式は，液晶部分の複屈折によ り, 透過光が波長によって異なるため, 表示が着色 (イエローモードあるいはプルーモード) する問題が あった。 そのため, コントラスト, 視認性が低下し, 任意のカラー表示も困難であった.

この問題を解決するため, STN 液晶セルを二層 (一つは色補償セル) 用いる三潧方式が開発され, 白 黒表示および任意のカラー表示が可能となった。この 二居方式は, STN 方式に比べて，厚くて重いという 欠点を有する：しかし，色補償セルのかわりに，それ と同等の機能を有する当社の開発した光学位相差フィ ルム, スミカライトを用いることによって, 薄くて軽 いという液晶表示装置の特徴を生かしたままで, 白黒 表示が可能となった，スミカライトの今後の成長が期 待される.

\section{2. 構造と物性}

スミカライトは, ポリカーボネート系フィルムを, 特殊な延伸技術により，一軸に粈密延伸して得られる ものであり, 透明性に優れた光学的に均一な複屈折性 (フィルム面内の屈折率異方性) を有するフィルムで あって，偏光の状態をかえるために用いられる，スミ カライトの主な仕様を下記に示す。

(1) 光線透過率: $90 \%$ 以上

(2) フィルム厚み: $50 \sim 200 \mu \mathrm{m}$

(3) 光学特性值 (位相差) : 任意に設定可能

(4) 光学的均一性: 極めて良好

(5) 耐久性能：すべての偏光板との組み合わせで使 用でき, 偏光板より良好

\section{3. 用途}

スミカライトを STN 型液晶表示装置の色補償フィ ルムとして用いることによって，下記の特徽を有する
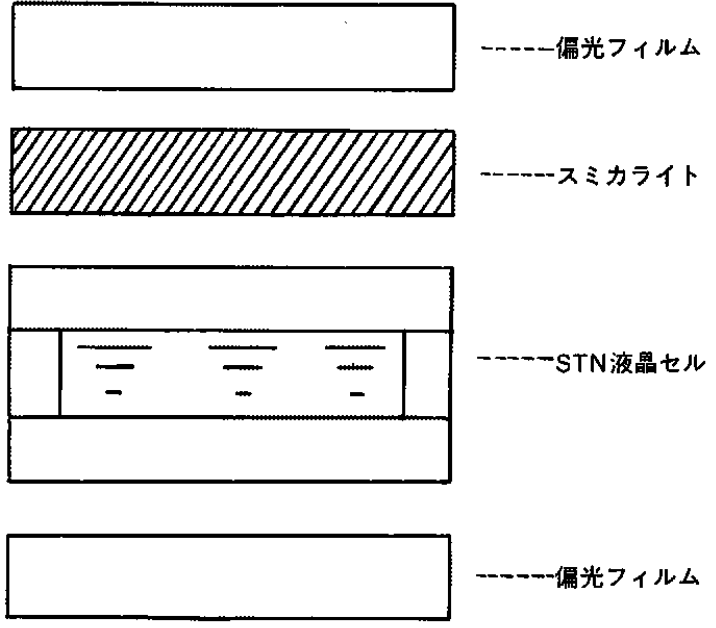

図 カスミライトを用いた STN 型液晶表示装貫の例

液晶表示装置が得られるようになった，この装置は， 薄型・大型ディスプレイ機器として極めて有望である.

(1) 薄くて軽い大容量の白黒表示 $\rightarrow$ 将来任意のカラ 一表示

(2) コントラスト比が STN 型に比べて1.5〜2.0 倍と非常に良好

(3) 透過および反射モード，ネガおよびボジモード のいずれも可能

(4) EL ランプをバックライトとして使用可能 その他，スミカライトの光学特性を利用した種々の用 途が考えられている.

\section{4. 将来動向}

当社は，スミカライトの製造技術を確立し，市販し ている.スミカライトを用いた STN 型液晶表示装置 の高品質化への要求に対応するため, 光学特性值の均 質化, 複届折性の制御, 最適特性を有するポリマーの 合成などに着手し，その基本技術を確立している。

\section{住友化学工業 (株) \\ 新規事業部}

本 社

(341 大阪市中央区北浜 4-5-33

80 06-220-3423 


\section{オプトレッツ ${ }^{\circledR} \mathrm{OZ}-1000$}

光学レンズ用低吸湿 - 高耐熱性プラスチック

\section{1. 技術の背景}

オプトエレクトロニクス技術の発展に伴い，コンパ クトディスクやレーザーディスク用のプレーヤー， ス チルカメラ，ビデオカメラ，投写型 TV など民生用 光学機器の小型・軽量化が促進されている. 非球面プ ラスチックレンズの使用も，そのための方策の 1 つで ある、ところが, 既存の光学用プラスチックを用いた レンズは，吸湿率が大きく，しかも耐熱温度が低いた め使用環境雾囲気によって, 光学性能が著しく低下す るという問題をかかえている，そこで，日立化成は， 独自に開発した特殊アクリルモノマーと長年培った熱 可塑性プラスチックの合成技術を基盤として，低吸湿 性と高耐熱性に優れた光学レンズ用熱可塑性プラスチ ック・オプトレッッ” ${ }^{\circledR} \mathrm{OZ}-1000$ を開発した。

\section{2. 特徵}

1) クラウン系光学ガラス領域の光学定数

屈折率 $\left(n_{0}\right)$ が 1.50 , アッベ数 $\left(\nu_{0}\right)$ が 57 とレンズ 用プラスチックとして広範囲にわたって用いられてい るポリメチルメタクリレート (PMMA) と同領域の光 学定数を有す.

\section{2）低吸湿性に優れる}

飽和吸湿率が小さいので (1.0\%), 吸湿による寸法 変化は $0.18 \%$ 以下であり, PMMA のそれの約 $1 / 2$ である.このため, 吸湿に伴うレンズ焦点距離の変化 は， $0.1 \%$ 以下となる。

3）耐熱性に優れる

ガラス転移温度が $122^{\circ} \mathrm{C}$, 熱変形温度が $103^{\circ} \mathrm{C}$ と高 いので, クラウン系のプラスチックレンズの中で最も 高い実用耐熱温度 $\left(85^{\circ} \mathrm{C}\right)$ が達成できる.

4）透明性に優れる

近紫外〜遠赤外領域にわたって, PMMA と同等の 光透過率を示す．また，樹脂骨格にフェニル基などを 有さないこともあり, 紫外線曝露による光線透過率の 低下はみられない。

5）複届折が小さい

OZ-1000 は，フェニル基などのような分子配向し やすく，しかも分極率の大きな基を有さないこともあ り, 成形品の複屈折は小さい.

6）容易な成形加工

流動性に優れ，しかも非晶質であることから射出成 形などにより, 精度の高い光学成形品が得られる。

\section{3. 用途}

“オプトレッツ®” OZ-1000 は，前記の特徴を有し，

高分子 38 巻 6 月号增刊 (1989 年)

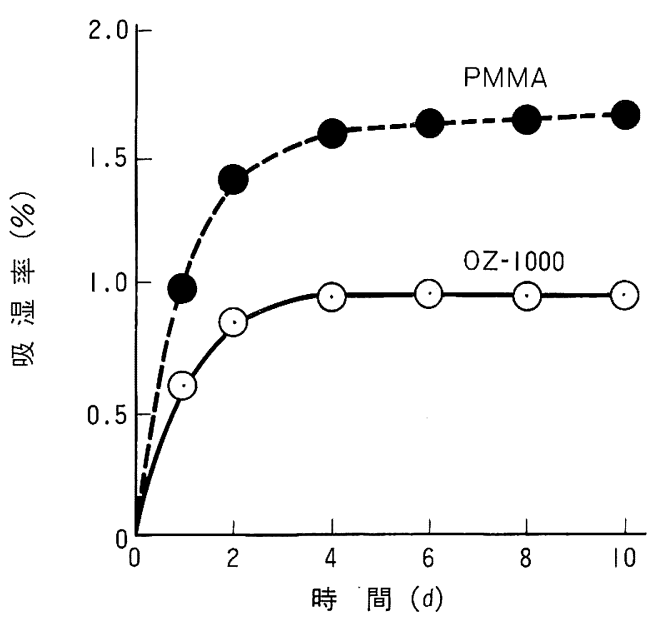

図 吸湿率の経時変化 $\left(60^{\circ} \mathrm{C} 95 \% \mathrm{RH}\right)$

しかも物性のバランスのとれたレンズ用プラスチック である。このため，ビデオカメラ用ズームレンズ，レ ーザーピックアップレンズなどの実用化に供され, 各 種カメラ, OA 機器, ハイビジョン対応プロジェクシ ヨン TV, TV 電話などのレンズへの応用も期待され ている.

4. $\mathrm{OZ}-1000$ の特性例

\begin{tabular}{|c|c|c|c|}
\hline \multirow{3}{*}{\multicolumn{2}{|c|}{ 屈 折 率 }} & \multirow{3}{*}{$\begin{array}{l}n_{p} \\
n_{\mathrm{F}} \\
n_{\mathrm{C}}\end{array}$} & 1.4997 \\
\hline & & & 1.5064 \\
\hline & & & 1.4976 \\
\hline \multirow{3}{*}{\multicolumn{2}{|c|}{$\begin{array}{c}\text { ヅ 数 } \\
\text { 届 } \\
\text { 光 線 透 過 }\end{array}$}} & $\nu_{\mathrm{D}}$ & 57 \\
\hline & & 折 & $5 \mathrm{~nm}$ \\
\hline & & 率 & $93 \%$ \\
\hline \multirow{2}{*}{\multicolumn{3}{|c|}{$\begin{array}{l}\text { 飽和 吸湿 率 } \\
\text { 吸湿寸法変化率 }\end{array}$}} & $1.0 \%\left(60^{\circ} \mathrm{C}, 95 \% \mathrm{RH}\right)$ \\
\hline & & & $0.18 \%$ \\
\hline \multicolumn{3}{|c|}{ ガラス転移温度 } & $122^{\circ} \mathrm{C}$ \\
\hline \multirow{4}{*}{\multicolumn{2}{|c|}{ 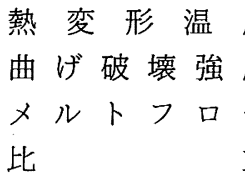 }} & 度 & $103^{\circ} \mathrm{C}$ \\
\hline & & 度 & $420 \mathrm{~kg} / \mathrm{cm}^{2}$ \\
\hline & & - & $4 \mathrm{~g} / 10$ 分 $\left(230^{\circ} \mathrm{C}, 3.8 \mathrm{~kg}\right)$ \\
\hline & & 重 & 1.15 \\
\hline
\end{tabular}

\begin{tabular}{l}
\hline 日立化成工業（株） \\
化成品事業部 \\
巴 163 東京都新宿区西新宿 2-1-1 \\
⓪3-346-3111(大代表)
\end{tabular}




\section{ゴム光ファイバー}

\section{1. 技術の背景}

ブリデストンは，長年にわたって培ってきたゴム技 術を基盤にして, 材料, 製法などに種々研究・開発を 重ねた結果, コア, クラッド、被覆材のすべてがゴム 弾性材料からなる, オールゴム製光ファイバを世界で 初めて開発した. ゴム特有の柔軟性, 耐衝撃性および 耐熱性の良さを利点として備え, 従来のガラス系およ びプラスチック系の光ファイバーでは困難であった 種々の用途への応用が期待される.

\section{2. 構造と物性}

当社のゴム光ファイパーは, ステップ・インデック ス型の光ファイパーで，コアとクラッド材には屈折率 の異なる透明シリコーシゴムを, 被覆材には外乱光除 去, 耐久性向上のためにフッ素系ゴムを用いており， 外径は $3 \mathrm{~mm}$ である. 光ファイバーの透光性を左右す るものに材料自身の吸収と, 不純物混入やファイパー 構造の不完全性などに起因する散乱の 2 つがあるが, 当社は, 材料およびプロセスの研究・開発により, 上 記損失要因を徽底的に排除することで, ゴム材料の光 ファイバー八の適用を可能とした。すべての素材をゴ ム弾性材料にて構成したことにより, 従来の光ファイ

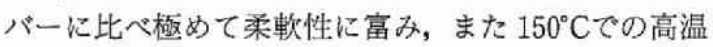
使用を可能としている. 表にゴム光ファイパーの特性 を示す

\section{3. 特徵および用途}

ゴム光ファイパーは従来のガラス系, プラスチック 系光ファイバーに比べ, 次のような特徵を有してい る.

（1）柔軟性に富み, 屈曲, 伸び, 衝撃などに強い.

（2）シリコーンゴム，フッ索系ゴムを素材に用いてい るため, 耐熱性, 而寒性, 耐久性に優れる.

（3）ゴム弾性のため, 外力に対し変形し易く, その結

果, 外力の大きさに応じた伝送光量の変化を生じ, センシング機能を発現することができる.

用途としては, 耐熱性, フレキシブルな配線が可能 なことを生かして, 自動車エンジンルームやオーブン などの高温機器内部の光通信用として, また, シリコ ーンゴムの人体適合性を生かした医療分野への応用が 考えられる. さらに，ゴム光ファイパーのセンシング 機能を生かした，センサー・スイッチ分野への応用が 可能である. そこで当社は, ゴム光ファイパーをセン サ部に応用した, アナログ検知が可能な線状感圧セン サ（商品名：オーネス）を開発した. 外力のアナログ

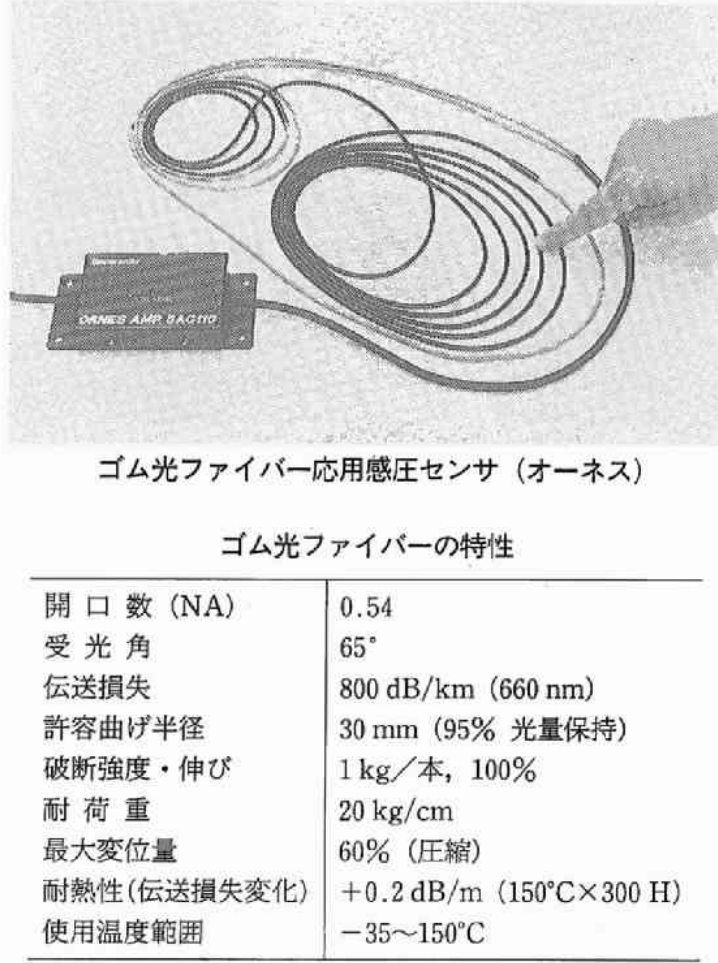

検知が可能なほか，任意に設定した感度て ON/OFF 信号を送り出すことができる。また耐衝撃性，耐熱性 に優れ，断面が丸いのでセンシングに方向性が無いな ど, 数々の特徴を備えている. スイッチ・センシング 素子として, 自動車, ロポット, 土木, 防犯, 計測, 医療，ゲームなどの広範な分野で用途開発を展開中で ある.

\section{4. 将来動向}

ゴム光ファイバーのセンシング機能を応用したセン サ・スイッチ分野での用途拡大が期待できる。 また, 伝送損失の低減, ファイパーの細径化の達成により, 中・短距離光通信への応用が可能となり, それによっ ていっそうの応用分野への拡大が期待される.

\section{（株）ブリヂストン}

工業用品開発棠業部

恶104 東京都中央区京橋 1-10-1

a 03-563-6931 FAX 03-567-0127 


\section{ユーピロン ODX}

\section{光磁気ディスク用低複屈折材料}

\section{1. 書換え可能な光磁無ディスクの技術的背景}

高密度記録媒体として光ディスクが，実用段階にな ってきている，特に韶換え可能なディスクが注目を集 めている。

書換え可能な光磁気ディスクでは，再生方式として は，カー回転効果やファラデー効果などの磁化状態に よるレーザービームの偏向面の微妙な回転の差を利用 している。そのためディスク材料の複屈折が $\mathrm{C} / \mathrm{N}$ 比 に悪影響を与える。

また，レーザービームを対物レンズによって集光し

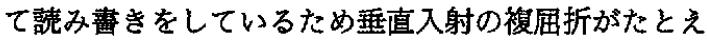
ゼロであってもレンズ外周部から入射してくる斜め入 射光による複届折が問題となる。

ポリカーボネート樹脂は, 化学構造の理由で, この 斜め入射の複届折が高くなる久点がある。例えば, レ ンズの開口度が 0.5 のとき, 垂直入射の複屈折がゼ口 であっても外周部の斜め入射 (30 度) の複屈折は, 約 $80 \mathrm{~nm}$ になる。この欠点を軽減するためハード側 では，差動光学へッドを用いて対応している，しか し，材料の改良についても要求が強く，分子設計の手 法を用いた検豇が必要であった。

この度, 三菱瓦斯化学(株) で開発した低複届折林 料「ユーピロン ODX】は，斜め入射と垂直入射の複 凮折を極力小さくコントロールした，すなわち［卫 一ピロン ODX」は, 固有の複屈折がプラスのポリカ 一ボネートとマイナスのスチレン系樹脂とをグラフト 共重合させたものである.

\section{2.『ユーピロン ODX』の特徵}

a. 光学的に均一で光線透過率が $91 \%$ である.

b. 複届折は, 斜め入射 (30 度)，垂直入射とも 15 nm 以下でノイズレベルは PMMA 並である。

c. 耐熱性は PC 並である.

d. PC にくらべ硬度が高い.

e. PC 上り飽和吸水率が低く, PCの 70\%である。

f. ミクロンオーダーのダストが制御されている。

g. 成形加工性が PCよりも優れる。

『ューピロン ODX」と従来の光ディスク用ポリカ ーボネート招よびポリメチルメタクリレートの性能比 較を表に示す。

以上のように『ユーピロン ODX」は，光磁気ディ スク用として優れた性能を有する新規な材料である。

この材料は，ピックアップレンズのようなプラレン ズ分野の用途にも有用な材料となるものと思われる.

\begin{tabular}{|c|c|c|c|}
\hline 性頁 & ーヒำ & 光元用 P $\mathrm{PC}$ & PMMA \\
\hline \multicolumn{4}{|l|}{ 光学的性質 } \\
\hline 光透過率 & 91 & 91 & 93 \\
\hline $\begin{array}{l}\text { 㞑折率 } \\
\text { 複屈折 }\end{array}$ & 1.59 & 1.59 & 1.49 \\
\hline （垂直） & $<15$ & $<15$ & $<15$ \\
\hline$\left(30^{\circ}\right.$ 斜め) $\mathrm{nm}$ & $<15$ & $<70$ & $<15$ \\
\hline 熱・機械的性質 & & & \\
\hline 軟化温度 & $>130$ & 145 & 110 \\
\hline 引張強度 $\mathrm{kg} / \mathrm{cm}^{2}$ & 600 & 620 & 440 \\
\hline 引張伸び & 6 & 31 & 2 \\
\hline 飽和吸水率 & 0.25 & 0.34 & $>2.2$ \\
\hline
\end{tabular}

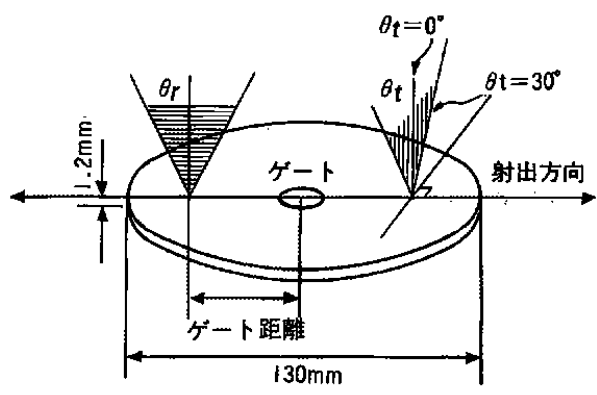

図 1 ディスク薪板複屈折の測定法

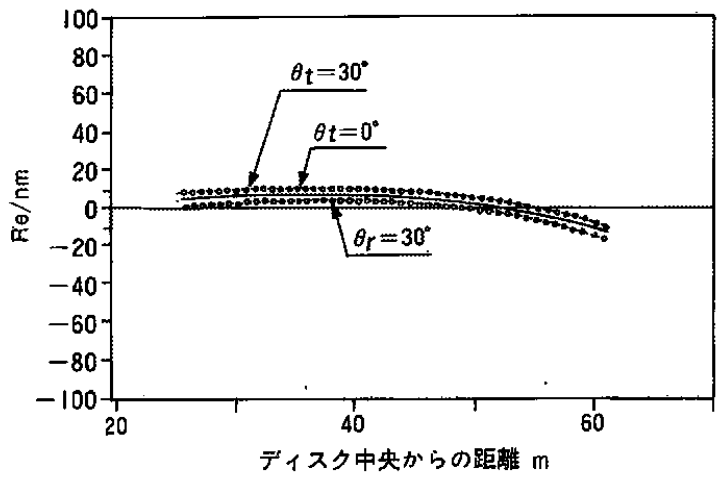

図 2 ディスク基板の複屈折分布

\section{三菱瓦斯化学（株）}

合成樹脂開発部

8300 東京都千代田区丸の内 2-5-2（三菱ビル） 03-283-4853 


\section{アクリペット ${ }^{\circledR}$ (光学グレード $)$}

メタクリル樹脂成形材料

PMMA（ポリメチルメタクリレート）浪，樹脂の 中でも最も優れた透明性を有し，かついろいろな環境 下においても，その性能が維持されるがゆえに，用途 の多くは，何らかの意味で光学材料としての使われ方 となっている. 最近の光ディスク, 光ファイバー, 光 学レンズなどオプトエレクトロニクス分野では, 光学 性能の向上，寸法安定性の向上，過酷な条件下での性 能維持がよりいうそう求められ, 耐熱性付与, 低吸湿 化などが目下 PMMA の重要な改質の方向となってい る.

三菱レイヨンは，これらのニーズに応えるべく，光 学部材用として, 次のような代表的射出成形用特殊グ レードの開発を行っている。

(1) レンズグレード グレード名ＨDT

吸水率

$\left({ }^{\circ} \mathrm{C}\right) \quad$ ， 飽和/室温）

TE-201

91

0.8

WF-100

104

1.3

TE-415

121

1.7

(対比) VH

100

2.1

耐熱性向上と低吸湿化を両立させることは一般にむ づかしいが，WF-100 および TE-415 は，一般用耐熱 グレードの VH よりも HDT が高く, かつ飽和吸水 率も改良されている。

(2) ディスクグレード

グレード名ＨDT 流動性

$\left({ }^{\circ} \mathrm{C}\right)\left(\mathrm{g} / 230^{\circ} \mathrm{C}, 3.8 \mathrm{~kg}, 10\right.$ 分 $)$

TH-1

100

4

TF-3

90

21

PMMA は，他の樹脂に比較し，複届折が小さく， 表面硬度が高く, 成形性が良いなどの特徵を有してい るが, 上記グレードはこれらの特徴に加えて, 加熱分 解特性に優れ，また塊状重合プロセスで製造されるた め, 微小異物の混入が極めて少なく, 高純度であるな どの性能を有する.
（3）超耐熱透明グレード

$\begin{array}{lcc}\text { グレード名 } & \begin{array}{c}\text { HDT } \\ \left({ }^{\circ} \mathrm{C}\right)\end{array} & \begin{array}{c}\text { 全光線透過率 } \\ (\%)\end{array} \\ \text { ST-300 } & 110 & 91 \text { 以上 } \\ \text { ST-200 } & 115 & n \\ \text { ST-100 } & 120 & \prime \prime \\ \text { PMI-130 } & 130 & n \\ \text { PMI-140 } & 140 & n \\ \text { PMI-150 } & 150 & \prime \prime\end{array}$

機械的強度, 耐紫品性, 成形加工性など主要な性䓄 は通常の PMMA 成形材料の性能を保持しているが, 複届折, 飽和吸水率については, 前述のレンズグレー ド, ディスクグレードの方が優れている。したがって 高度の性能が要求される光学レンズ, 光ディスクの精 密光学部品よりは，一般的には車輛用各種レンズ類, 照明あるいは機器類のカバーなど透明性, 而熱性の要 求される用途に適している.

PMI シリーズは，現在開発を進めているものであ るが，ST シリーズと異り，イミド基を含有するもの で，耐熱性でポリカーボネートを凌ぐものも得られ， 表面硬度，剛性も高い，新しい透明エンプラ材料とし ての用途がひらけることを期待している.

\section{三菱レイヨン（株）}

本社 アクリペット部

西 104 東京都中央区京櫑 2-3-19

03-245-8716

東京研究所 樹脂応用第二技術センター

241 神宗川県川崎市多摩区登戸 3816

8044-933-7221（代） 


リポソーバー LA-15 システム

\section{血獎浄化システム}

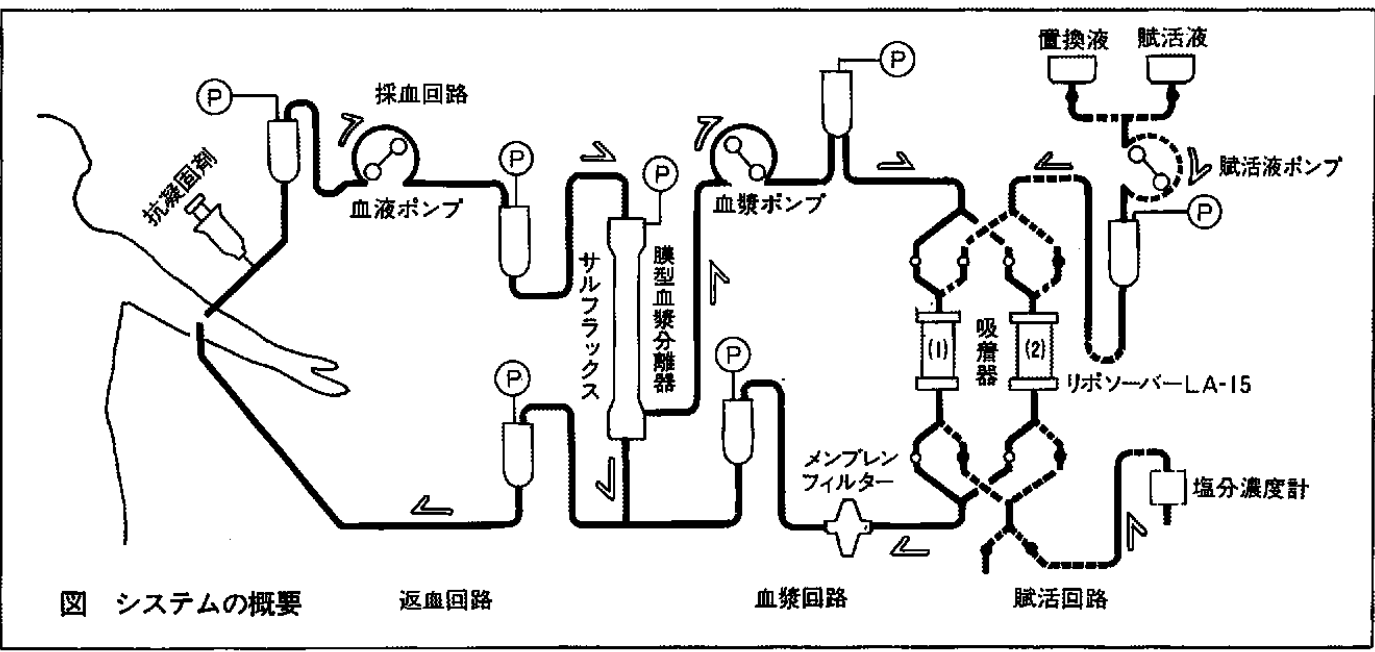

\section{1. 技術の背景}

高脂血症（高コレステロール血症）は，虚血性心疾 患の最重要リスクファクターとして知られています が，食揧療法，薬物療法では治療効果が不十分である 症例がかなり見られ，最近，血槳净化療法にその治療 効果が認められ，普及しています.

その血漿浄化療法のなかで, 血槳製剂を使用しない 選択的血装成分吸着器（リポソーバータ) を用いた 「リポソーバー LA-15 システム」(Continuous LDL Apheresis System) は，血將中の過剩な LDL（低密 度リポタンパク）を吸着除去し，高脂血症およびその 合併症を改善するために開発されたシステムです。

\section{2. 特與}

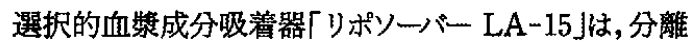
された血墏中よりアポリポタンパク B含有りポタンパクを 除去することを目的とし，次の特長をもっています．

(1) LDL, VLDL に対し，高い選択的吸着能を有して います.

（2）賦活回数を変えることにより，吸着量を任意に設 定できます

（3）HDL は，ほとんど減少しません。

（4）脂質以外の血漿成分にはほとんど影響を与えませ ん.

（5）アルプミンなどタンパク質の吸着が少ないため, 特別の場合を除いてアルプミンなどの補充液は不 要です

3. システムの概要

本システムは, 膜型血槳分離器 (サルフラックス FS-
05), 選択的血獎成分吸着器 (リポソーパー LA-15), 血 液回路（血漿交換療法用回路 LT-MA2），血奬净化装 圈（MA-01）を組み合わせて使用し，血熬中の LDL （および VLDL）を吸着・除去するシステムです。

図に示されるように, 血液ポンプにより引出された 血液は, 膜型血漿分離器により血漿画分と血球画分に 分離されます 分離された血獎は選択的血槳成分吸着 器により LDL を吸着・除去し, 净化された後に血球 画分と合流し，患者の体内に戻されます。

リポソーバー LA-15の 2 本の LDL 吸着器は, 自 動的に賦活されて交互に繰返し使用されます。賦活は 専用の賦活液 (4.1\%食塩液)により行われます。賦 活後の吸曾器は, リングル液などに置換された後に使 用されます。

（注）賦活とは，吸着器に吸着された LDL を専用の 賦活液（ $4.1 \mathrm{~W} / \mathrm{V} \%$ 食塩液）により吸着器より脱離 させ，再び吸着可能な状態にすることをいいます。 ※本システム忙医療用具を用いる治療行為です. 本シ

ステムの適用にあたっては医師の判断により，実施 して下さい.

\section{鐘淵化学工業(株)}

\section{医薬品事業部}

本 社 530 大阪市北区中之島 3-2-4

Z 06-226-5137 医楽品事業部医療器大阪営業部

東京支社 -107 東京都港区元赤坂 1-3-12 203-479-9570 医薬品事業部医療器東京営業部 


\section{エバール膜（KF シリーズ, エバフラックス）}

エチレン・ビニルアルコール共重合体樹脂

\section{1. はじめに}

近年, 高分子化学の発達に伴い, 各種中空糸膜が開 発され，医爎用分野，特に体外循環による血液浄化法 に応用され，数多くの実續を上げ，医療分野の中で大 きな地位を占めている，血液浄化法とは，血液を体外 に取り出し，血中の病因関連物質を各種中空糸膜によ り分離し，血液を浄化する方法である．古くは㹂不全

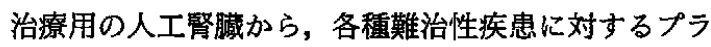
ズマフェレーシスまで非常に多䀞にわたって臨床応用 されている.

\section{2. 膜の特徵}

エバール膜は，エチレン・ビニルアルコール共重合 体樹脂（エバール樹脂）を原料とし，各種紡系方法に より製膜される。

化学構造式 $\left.\left.\quad+\mathrm{CH}_{2}-\mathrm{CH}_{2}\right)_{m}+\mathrm{CH}_{2}-\mathrm{CH}\right)_{+}$

平均孔径は $40 \AA$ から $400 \AA$ までの孔径を有した均質 構造膜が作製され，人工掔臟から，プラズマフェレー シスの血嶈成分分離器まで幅広く使用されている.

膜の特徵は，(1)樹脂のみならず，製膜時においても 油剤, 可塑剂, 中空系形成剤などの添加剤を必要とし ない. 安全性を非常に配虑した膜となっている。（2)エ バール樹脂は，1 分子中に蹯水性セグメント（エチレ ン）と親水性セグメント（ビニルアルコール）を有 し，その物性は，組成により大幅に変化する，医療用 エバール膜は, 両者の比率について, 透過性能, 機械 的性質，血液適合性などの観点から種々検討し，エチ レン含有率約 $30 \%$ 程度に設定している。

\section{3. 用途}

\section{3-1. 人工緊茂}

腎不全の治療に，人工腎臓による透析療法が導入さ れ，数多くの患者の延命に効果を上げてきた，透析療 法の向上とともに, 透析治療が長期化し, それに伴 い,さまざまな合併症がクローズアップされている。 人工腎臓の要求性能が単なる延命から, Quality of life を求めるレベルになってきた.

膜の除去性能についても同様であり，単なる低分子 物算の除去から，従来の人工監膱に欠けていた，中，

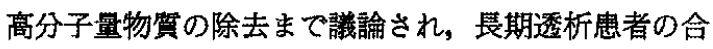
併症との関係が問題となっている.エチレン・ビニル アルコール共重合体膜（製品は $\mathrm{KF}$ シリーズ）は，尿 素, クレアチニンに代表される低分子物質から，数万 の分子量の小分子タンパクを含めた中, 高分子量物質

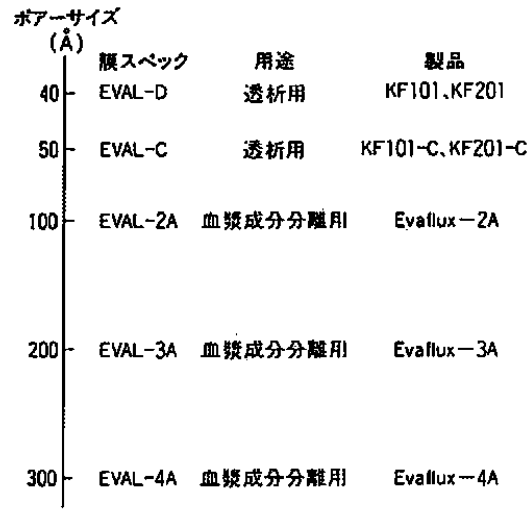

図中空系の種類

まで，幅広い除去性能を有している，臨床の面加ら は, 数多くの施設にて, 長期透析患者の合併症である 貧血, 関節痛, 瘦痒感の改善に良好な臨床効果を上げ ている.

\section{3-2. プラズマフェレーシス}

プラズマフェレーシスは，血液の血漿中に存在する タンパク質などの高分子墨の病因関連物質を除去し， 家族性高脂血症，慢性関節リウマチ，重症筋無力症， 高マクログロブリン血症, 劇症肝炎などの種々の難治 性疾患の治療に臨床応用され良好な成績を上げてい る.

方法としては，1）分離血墏をすべて廃楽する血墏 交換法，2）分離血频中の病因関連物質を含む高分子 量物望を分離・廃棄するダブルフィルトレーションプ ラス゚マフェレーシス (DFPP 法)，3）分離血漿中の病 因関連物筫を吸着除去する血漿吸着法が行われてい る.

エチレン・ビニルアルコール共重合体膜（商品はエ バフラックス）は 2)の方法における血嶈成分分離器 として使用されている.

以上のように現在はれ径による分離が中心である が, 将来的には, 各種官能基の導入が比較的簡単な材 料であるので, より選択性のある膜による展開が期待 される.

\section{(株) クラレ}

亚 530 大阪市北区梅田 1-12-39

206-348-2283 研究開発本部

×06-348-2583 メディカル事業本部 


\section{中空糸型人工腎臓}

\section{高性能血液透析膜}

人工材料で生体機能を代行する代表的なものに人工 腎臟がある，週 2 3 回の透析療法を受けておられる 患者数は日本で約 8 万人, 世界では約 30 万人にのほ り, 最も長い透析歴は 20 年以上にいたっている.

透析歷が長くなるととも活々の合併症が発生して くるが, 1986 年下条博士らにより, 長期透析患者に 多発する手根管症候群を始めとした種々の骨関節症状 を引き起こす原因物質が $\beta_{2}-\mathrm{MG}$ (ミクログロブリン, 分子量 11,600 ) と同定され, 対策としてこの分子量 領域の除去に焦点が絞られてきた。

従来の人工腎臓は低分子量の老廃物を膜の孔で拡散 除去する機構に依存しており， $\beta_{2}-\mathrm{MG}$ のような大分 子量の物質を透析により除去することは原理的に困難 であった，そのため膜の孔径を大きくする試みがなさ れてきたが， $\beta_{2}-\mathrm{MG}$ を十分に除去し得る大きな孔径 を持つ膜においては, 有用タンパクであるアルブミン （分子量 67,000 ）まで除去されてしまい, 長期使用で 㹥問題となっていた.

これに対しアルブミンのリークなしに $\beta_{2}-\mathrm{MG} を$ 散除去し得る, 従来概念では矛盾ともいえる要求特性 を解決したものが, 東洋紡で開発したトリアセテート 中空系型血液透析膜である.

\section{1. 仕様}

(1) 素材：トリアセテート

（2）形状：中空系型（内径 $200 \mu \mathrm{m}$ )

クリンプ付与により透析液側境膜抵抗を極 限まで減少

（3）膜厚 : $15 \mu \mathrm{m}$ の均一厚み薄膜

(4) 構造: 平滑な内面微細構造

\section{2. 特徵}

（1）生体膜に近づけたシャープな分画特性

膜の孔径制御により，膜面上での開孔率を高めると ともに $\beta_{2}-\mathrm{MG}$ が拡散機構で透過し得る孔径を付与し た. しかも，血液が流れる際には中空系膜の内面にア ルブミンの単分子層が形成され, 形成された単分子層 がアルブミンのバリアとなってリークを防ぐとともに $\beta_{2}-\mathrm{MG}$ の透過能を保持し得る, 生体腎臟に類似した 分画特性を持つ.

（2）クリンプ中空系による高い透析効率

中空系膜自体にクリンプを付与することにより，膜 全体をモアレ構造化している. モアレ構造は中空糸膜 集合体としては整然とした配列を有しながら, 透析液 が流机る際にも系同志が密着することなく，1本1本

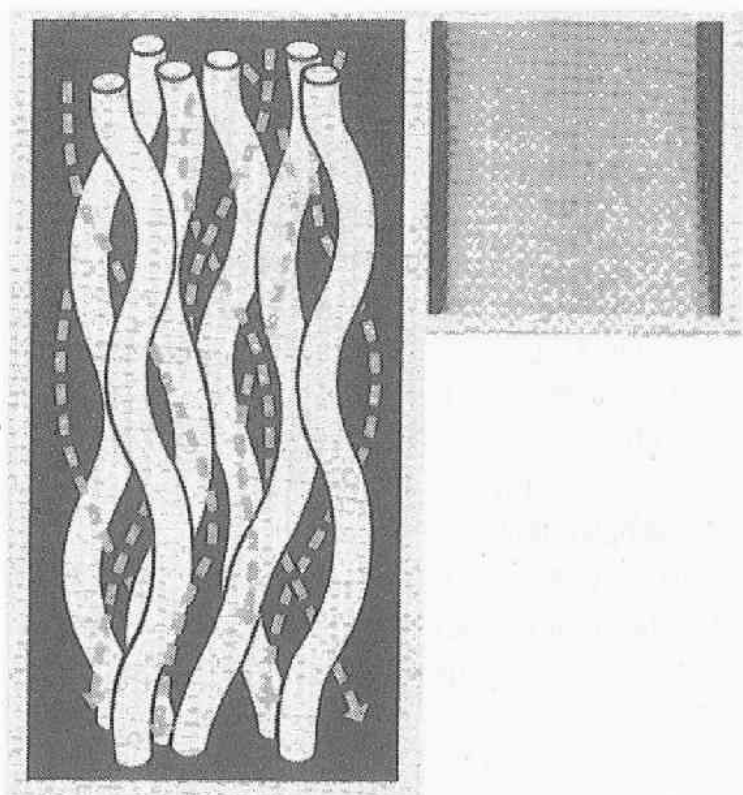

透析液は，中空糸外側（点線部）を境膜を削ぎとる ように流れ，高い透析効率を発揮します。

の糸の間に透析液の均一な流れが発生する。この結果 透析液側の境膜抵抗が最小となり高い透析効率を有す 優れた人工腎臟性能が発現する.

（3）トリアセテートによる優れた生体適合性

トリアセテートの持つ適切な疎水/親水バランスは, 生体へのなじみに優れ, 生体の持つ複雑な防御機構で ある補体系や血小板系を活性化することなく，優れた 生体適合性を発揮している.

\section{東洋紡績（株）}

医用機材事業部

本 社

洜 530 大阪市北区堂島浜 2-2-8

80 06-348-3361

総合研究所

(1) 520-02 滋賀県大津市堅田 2-1-1

ฮా 0775-21-1481 


\section{フィルトライザー BK}

\section{ポリメチルメタクリレート系中空糸型血液透析器}

\section{1. ·技術の背景}

ポリメチルメタクリレート (PMMA).のステレオコ ンプレックス現象を利用した PMMA 系中空系膜は血 液透析膜や血液沪過膜として利用されるようになって 久しい. 1985 年に長期透析患者の合併症のひとつの 原因物質として分子量 11,800 の $\beta_{2}$-ミクログロブリ ン $\left(\beta_{2}-\mathrm{MG}\right)$ の有害性が明らかにされて以来, $\beta_{2}-\mathrm{MG}$ などの低分子量タンパウのの除去が人工腎臟の保有すべ きひとつの性能とされつつある. PMMA を膜素材と して用い, 本目的に合うよう設計された透析器がフィ ルトライザー BK である。

\section{2. 膜構造と性能}

PMMA 膜では，製膜条件を変更することにより， 広範囲の含水率, 細孔半径を持つほぼ均一な膜を得る ことができる，この性質を利用して，沪過性能の種々 異なった膜を用いたダイアライザーが製造されてい

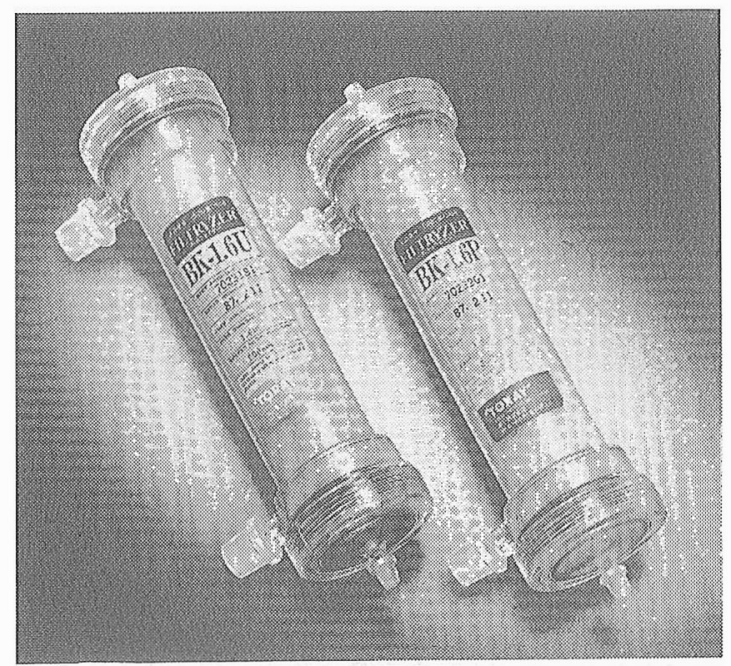

フィルトライザー BK の外観

る.

フィルトライザー $\mathrm{BK}$ 膜は, 膜厚 $30 \mu \mathrm{m}$, 示差熱

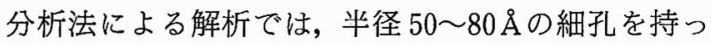
ている. (図)。この細孔の大きさは, 血液透析器本来 の機能である水, 尿素, クレアチニンなどの除去に加 えて $\beta_{2}-\mathrm{MG}$ などの低分子量タンパクの透過を可能に した。しかし，人体に有用なタンパク質であるアルブ ミン以上の分子量の血中成分は透過しない.

フィルトライザー $\mathrm{BK}$ 膜による $\beta_{2}-\mathrm{MG}$ の除去は, 透過だけでなく吸着による除去も行われており，その 寄与も大きい.

\section{3. 臨床効果への期待}

透析療法の進歩により 10 年以上透析を続ける患者 が増加している，それにともなって，骨障害など長期 透析合併症が改めて問題となっている。PMMA 膜は 白血球や補体などの血液成分への影響が少ない生体適 合性の優れた膜として知られ,さらに BK では前述 の合併症の原因物質のひとつとされる $\beta_{2}-\mathrm{MG}$ などの 低分子量タンパクを除去する機能が付与されており, 臨床症状の改善が期待されている.

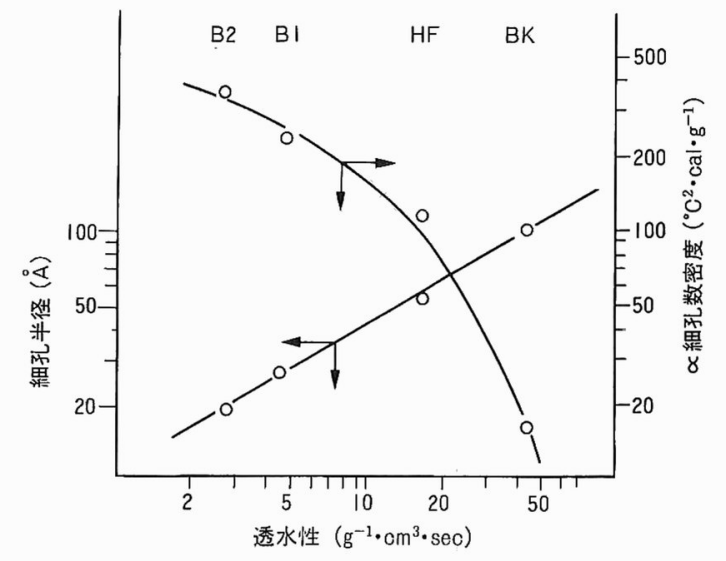

図 1 各種 PMMA 膜の膜構造上の位置付け

\section{東レ (株)}

丞103 東京都中央区日本橋室町 2-2-1

ซా 03-245-5680 FAX 03-245-5630 


\section{アンスロン®}

\section{抗血栓性材料}

東レのポリマーサイエンスの技術から生まれたへパ リン化親水性材料アンスロン®は, 人体に優しく, 生 体適合性に優れたバイオマテリアルである.

徐々に放出されるへパリンにより，長期にわたって 優れた抗血栓性を発揮するため, 各種カテーテルに応 用されている。

カテーテル術により血栓の形成が認められ, これか゚ さまざまな合併症を引き起こすことは数多く知られて いるが,これはカテーテルの長期留置においてのみで はなく, 数時間の短期使用においても深刻な問題にな っている.

アンスロン®をコーティングした各種カテーテル は, この血栓形成を防ぎ, より安全なカテーテル術を 可能にした.

\section{1. 抗血栓性のメカニズム}

アンスロン®は, 親水性ポリマーにヘパリンをイオ ン結合させた材料であり, 血中で図のようなメカニズ ムで徐々にへパリンを放出する.

材料表面のへパリンが(A), 血中に放出されても (B), 材料の内部に存在するへパリンが, 表面に移動 し (C), 血液と接触する面には常にへパリンが存在す る状態が保たれる。

このように, アンスロン®は長期間にわたりへパリ ンを徐放するため, テフロン, ポリエチレン, 塩化ピ ニール, シリコンなどの多種材料はもちろん, 他の抗 血栓性材料と比較しても, より長期間, 優れた抗血栓 性を維持することが可能である.
2. アンスロン®の臨床例
(1) 高力口リー翰液用
(2) 肝癌の動注・塞栓用
(3) 血管造影用
(4) 一時的プラッドアクセス用
(5) 門脈バイパス用
(6) 大動脈パイパス用

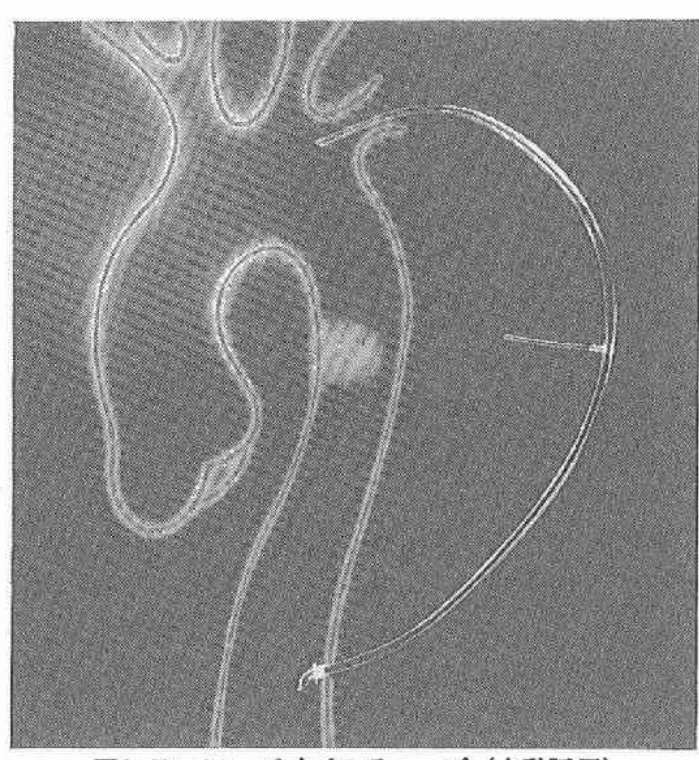

アンスロン®パイパスチューブ（大動脈用）

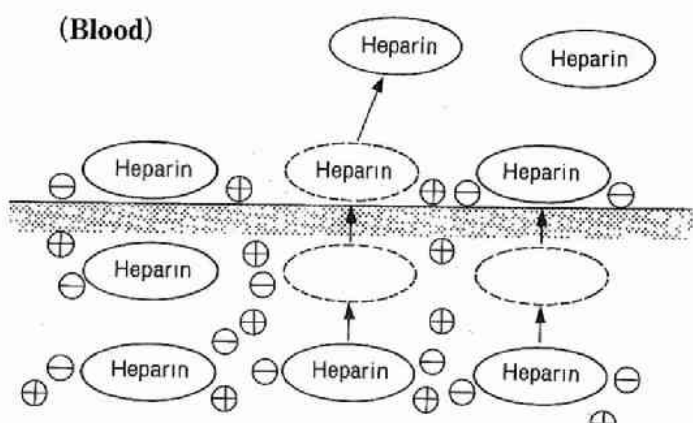

(Anthron $_{\mathbb{B}}$ )
(A)
$\longrightarrow$ (B)
(C)

図 1 抗血栓性のメカニズム 


\section{アシプレックス-F $\mathbf{F}^{\circledR}$}

\section{フッ素系イオン交換膜}

アシプレックス $-\mathrm{F}^{\circledR}$ とは, 旭化成が開発し，製造販 売しているパーフロロカーボン製の陽イオン交換膜で す

\section{1. 特徵}

アシブレックス $-\mathrm{F}^{\circledR}$ は，食塩電解用のイオン交換膜 として用いたとき，その特徴を最大に発揮するよう設 計されています，その特幑は，次のとおりです。

(1) 化学的に極めて安定

(2). 高度な陽イオン選択透過性

(3) 良好な電無伝筫性

(4) 高い製品純度

旭化成は, 1975 年に世界最初のイオン交換膜法苛 性ソーダ工場をスタートさせて以来，常にこの分野の パイオニアとして高品位の膜, 電極, 電解槽および電 解ブロセス技術を提供してきました，世界の食塩䉓解 でイオン交換膜法の占める割合は，まもなく20\%を 越えるところまできて招ります。今後もいっそうの拡 大が予想されて扔り，この面でのアシプレックス- $\mathrm{F}^{\circledR}$ の寄与が期待されています

\section{2. 樥造と性能}

ポリマーは, 基本的にはカルボン酸とスルホン酸の

2 層構造となっています。

カルボン酸：高度な陽イオン選択透過性を与える。

高い苛性ソーダ品質を保証する。

スルホン酸：イオン交換膜に必要な強度を与える. 高純度塩素ガスを得ることができる.

さらにイオン交換膜には PTFE 製の織布が埋め込 まれており，膜の引き裂き伝播抵抗を高めると同時に 膜に寸法安定性を与えています。

䉓解性能

電流効率 $95 \%$ 以上 $\left(\mathrm{Na}^{+}\right.$イオン選択透過率 $)$

電 圧 $3.0 \sim 3.2 \mathrm{~V}\left(3 \sim 4 \mathrm{KA} / \mathrm{m}^{2}\right)$

䔅性ソーダ (50\%) 中の食塩 $30 \mathrm{ppm}$ 以下

\section{3. 今後期待される用途}

食塩電解用隔膜としての用途に加えて,アシプレッ

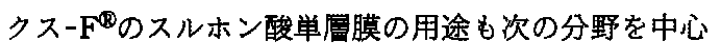
に期待されています

(1) 燃料電池用隔膜

(2) 各種の電解酸化・還元反応用隔膜

(3) 水電解による水素製造用隔膜

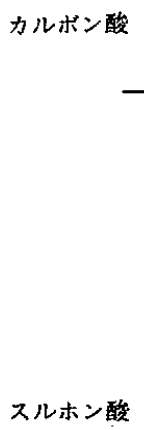

カルボン酸

スルホン酸 


\section{極性ガス除湿膜}

\section{フッ素系樹脂}

\section{1. ニーズの背景}

半導体素子の製造工程では, 多種の高純度ガスが使 用されている、それらのうち, 窒素, 水素などの非極 性ガスは，吸者刘などの良い乾燥技術があり，ppbの オーダーまで除湿されて使われている. 一方, 極性ガ スは吸着剤の適用が難しく, しかもガスそのものの吸 湿性が強いため, 半導体素子製造工程のガスのスース ポイントでは, 非極性ガスに比へてかなり水分が多い 状態で使用されているのが実態である.ところが, 半 導体素子の集積度があがり, 線幅が小さくなり, 各層 の厚みが薄くなるにつれて, 極性ガス中の主な不純物 である水分が問題視されるようになりつつある.

「極性ガス除湿膜」は，このように現在適当な技術 のない極性ガスの除湿を目的に開発されたものであ る.

\section{2. 除湿の原理と性能}

（1）モジュール：耐薬品性に優れ，かつ水分に対して 通択透過性を持つ, フッ素系樹脂中空系膜 (1本当り の太さ数百ミクロン) を数百本束ねて, 太さ $27 \mathrm{~mm}$, 長さ $627 \mathrm{~mm}$ のステンレス製パイプに納められてい る.

（2）使用方法：中空糸膜の外側を真空状態に保ってお き, 中空糸膜の入口から極性ガスを注入すると, 中空 糸膜と接触しながらガスがモジュールの中空系膜の内 側を通り抜ける間に，水分だけが選択的に中空系膜の 外側へ拡散移動し, 極性ガスは乾燥されてでてくる仕 組になっている.

（3）除湿性能 : 塩化水素ガスの場合, 露点 $-30^{\circ} \mathrm{C}$ (水 分約 $35 \mathrm{ppm}$ ) のガスを露点 $-65^{\circ} \mathrm{C}$ (約 $\left.4 \mathrm{ppm}\right)$ に下 げることができる，運転条件は原料がスの圧力 $3 \sim 9$ $\mathrm{kg} / \mathrm{cm}^{2} \mathrm{G}$, モジュールの処理能力は $1 \sim 3 \mathrm{~L} / \mathrm{min}$.

\section{3. 半導体素子製造プロセスへの適用期待効果}

半導体素子製造プロセスで使用されている塩化水素 に,この「除湿膜」を適用すると次のような効果が期 待される.

（1）ウエハまたはデパイスに直接または間接に接触す る塩化水素ガスに含まれている水分がなくなることに より，ウエハまたはデバイスの品質が向上する.

(2) 塩化水素を導入する配管，バルブおよび計器類の 腐食が少なくなり，サピに起因する重金属不純物がリ アクターに混入して起こるトラブルが防止できる.

（3）サセプター洗浄ガス八適用するとサセプターの表 面にコーティングされているシリコンカーパイド層の 高分子 38 巻 6 月号増刊 (1989 年)

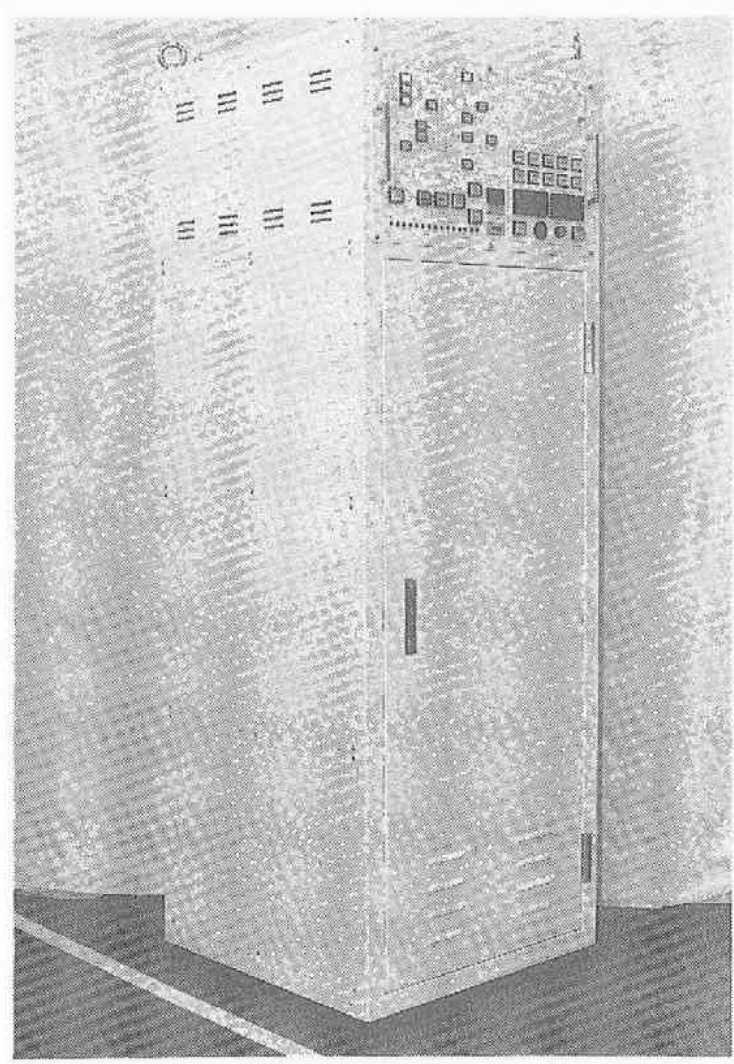

ピンホール発生が押えられ, サセプターの寿命が延ぴ る.

\section{旭化成工業（株）}

機能膜事業部商品開発部

(100 東京都千代田区内幸町 1-1-1

(インペリアルタワー)

జ 03-507-2255 


\section{レクタン ${ }^{\circledR}$}

\section{ポリプロピレン多孔中空糸膜材料}

\section{1. 技術の背景と市場動向}

宇部興産は, 長年培った高分子成形加工技術, 特に ポリオレフィン系樹脂の配向結晶化に関する基礎的研 究および溶融紡糸・延伸技術を基盤として, ポリプロ ピレン多孔中空系膜材料「レクタン®」を開発した. この膜材料は，原料のポリプロピレン樹脂から当社で 一貫生産体制をとり，安全性を考慮した特別な原料を 使用し, かつ溶剤を必要としない溶融紡糸法で製膜さ れている.

近年, 中空系膜フィルターと活性炭を組み合せた浄 水器の需要が高まっていること, 半導体製造などの電 子工業分野, 食品・医薬品・化学品などのファインケ ミカル分野などでも膜分離法が採用されつつあること から, クリーンで安全な精密沪過膜レクタンの成長が 期待される.また, ポリプロピレンは生体適合性にも 優れているため, 最近話題となっている血漿分離など のメディカル関連分野での需要も期待される.

\section{2. 特徵および用途}

写真にみられるように, ポリプロピレン多孔中空系 膜材料「レクタン」は, 中空糸膜周壁部に, 中空糸 膜の長さ方向に対し, ほぼ直角に走る比較的太いロッ ド群と, その各ロッド間につながる微小フィブリル群 とによって構成され, これらのロッド群および微小フ イブリル群によってほぼ均一な短冊状の微小孔群を形 成している、このため, 孔径分布は函めてシャープで あり,かつ空陵率も大きい. 微小孔形状のこれらの特 徵のため, レクタン®使用した精密沪過フィルター は, 微粒子や細菌の除去性能に優れ, かつ透水性が大 きく長寿命である. 微小孔形状は溶融紡系・延伸条件 により僌密に制御することが可能で, 広範囲の孔径 空隙率の多孔中空系膜材料が得られるため, 用途に応 じて最適な膜が選択される.

膜素材であるポリプロピレンは, 酸やアルカリに強 く, 広い範囲の有機溶㓮に対して耐久性がある. 加え て,レクタン®の原料となるポリプロピレン樹脂は, 衛生面での安全性を考慮して特別に当社で製造したも のであり, かつ製膜は溶剤を必要としない溶融紡系・ 延伸法によっているため, 溶剤や可塑剤などの夾雑物 が溶出することがなく, 極めてクリーンで安全な膜で ある.これらの特徴は, ポリプロピレンが生体適合性 に優れることと相俟って, 飲料水・食品・医薬品関連, メディカル関連用途から電子工業・化学工業関連用途 まで, レクタン®の利用できる用途範囲を極めて広範

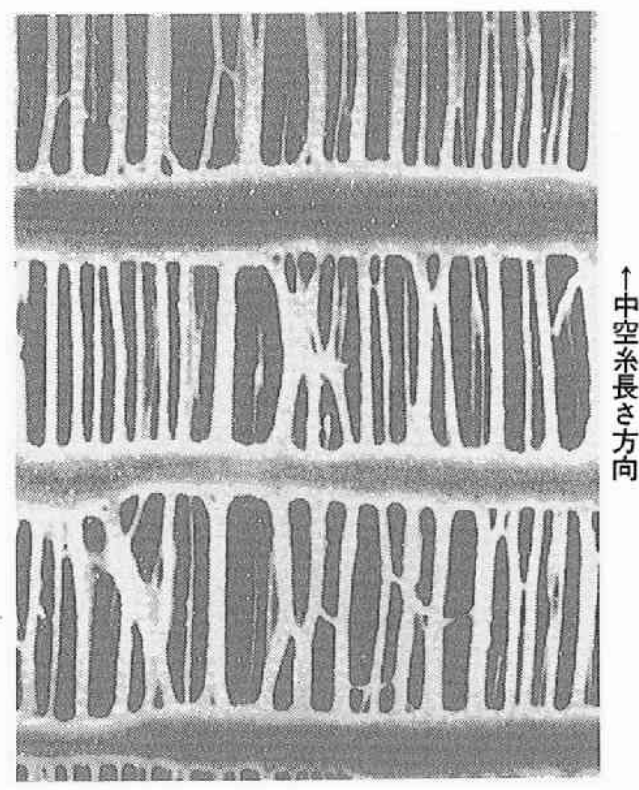

囲なものにしている.

次表にレクタン®の般的な仕様を示す.

\begin{tabular}{|c|c|c|c|c|}
\hline \multicolumn{5}{|c|}{ レクタン®の一般的仕様 } \\
\hline \multicolumn{5}{|c|}{$\begin{array}{lr}\text { 膜 厚 } & 50 \mu \mathrm{m} \sim 70 \mu \mathrm{m} \\
\text { 中空外径 } & 200 \mu \mathrm{m} \sim 800 \mu \mathrm{m} \\
\text { 分画特性 } & 0.05 \mu \mathrm{m} \sim 0.5 \mu \mathrm{m} \\
\text { 疎水性膜および親水性膜 } \\
\\
\text { 標準グレード }\end{array}$} \\
\hline \multicolumn{2}{|c|}{ グレード名 } & $\mathrm{PH}-10$ & PH-15 & $\mathrm{PH}-30$ \\
\hline \multicolumn{2}{|c|}{ 分 画 特 性 } & $0.1 \mu \mathrm{m}$ & $0.15 \mu \mathrm{m}$ & $0.3 \mu \mathrm{m}$ \\
\hline \multirow{2}{*}{ 中空系 } & 外径 & $430 \mu \mathrm{m}$ & $430 \mu \mathrm{m}$ & $430 \mu \mathrm{m}$ \\
\hline & 内径 & $320 \mu \mathrm{m}$ & $320 \mu \mathrm{m}$ & $320 \mu \mathrm{m}$ \\
\hline
\end{tabular}

レクタンシは現在, 携带用浄水器「ゾネス $\left.{ }^{\circledR}\right\rfloor$, 家庭 用清水器「清水くんき, 工業用途向「精密沪過カー トリッジ」などの各種精密汇過フィルター, ガス交換 膜, 菌体濃縮膜などに広く利用されるとともに, 血漿 分離などのメディカル関連用途にも商品展開中であ る.

\section{宇部興産 (株)}

研究開発本部・市場開発第二グループ

\$107 東京都港区赤坂 1-12-32 アーク森ビル ธా 03-505-9235

FAX 03-505-9234 


\section{フロロポア® フィルター}

\section{フッ素樹脂製高性能フィルター}

当社では, 従来より独自のフッ素樹脂加工技術によ り四フッ化エチレン樹脂 (PTFE) 単体から成るフロ ロポア®フルターを生み出し, 販売してきました. このフロロポア ${ }^{\circledR}$ フィルターは

(1) 抜群の耐薬品性

(2) 抜群の耐熱性 $\left(260^{\circ} \mathrm{C}\right)$

(3) 孔径の均一性と品揃え（0.1〜10 ミタロン)

(4) 高強度

を特良としています。

ところが最近では，半導体分野やバイオ，医療分野 で, より高流量, 高補集効率のフィルターが要求され るようになったきました，そこで当社では，その要求 に応えるため, 新しいタイプの高性能フィルターを開 発し，販売を開始しました。

\section{高流量かつ高捕集効率を達成}

今回開発した高性能フィルターは, 従来のタイプの 持つ特長に加え,

(1) $1.6 \sim 2$ 倍の液体流量

(2) $3 \sim 4$ 倍の気体流量

という特長も兼ね備えています。

また, 気体中の粒子捕集時, 最もフィルターの捕集 効率が低くなるといわれている $0.01 〜 0.1$ ミクロンの 粒径領域においても「99.9999999\% 以上の捕集効率」 を示すことが確認されました。

一般にフィルターは, 流量が大きくなると粒子捕集 効率が悪くなる傾向にありますが，本フィルターは， 両特性を同時に向上させた画期的なフィルターである といえます。

\section{親水性フィルターも開発}

PTFE 製フィルターは，一般に水をはじく性質が ありますが，当社は，用途により水が容易に漫透する よう表面処理をした親水性フィルターも開発しており ます.

当社ではューザーニーズの多様化に応じたフィルタ 一仕様を決め, 種々の用途に対応できるように努めて います。

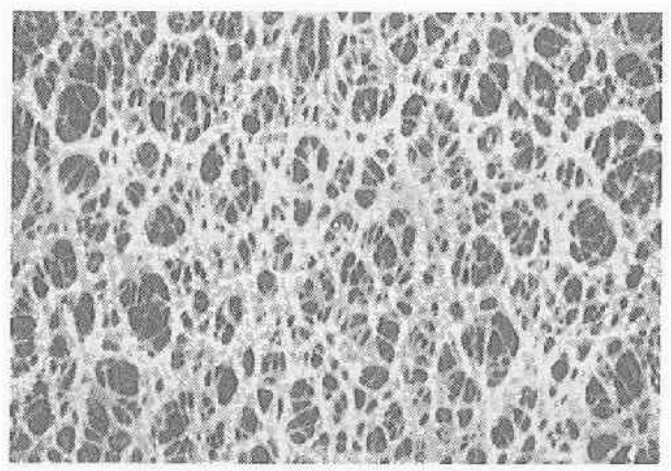

フッ菜樹脂製高性能フィルター電子顕微鏡写真

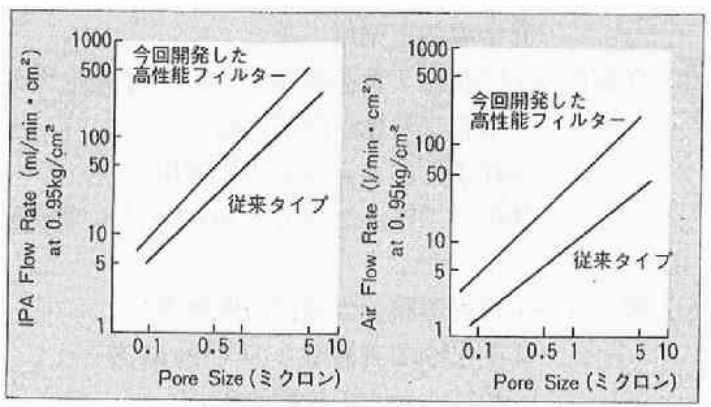

フロロポア®フィルター 孔径別液体流量比較図

フロロポア®フィルター 孔径別気体流量比較図

\section{住友電気工業 (株)}

ハイブリッド製品事業部大阪営業部

逐 554 大阪市此花区島屋 1-1-3

206-466-5564

ハイブリッド製品事業部東京営業部

(107 東京都港区元赤坂 1-3-12

జ 03-423-5151

ハイブリッド製品事業部弗素樹脂技術部

密 590-04 大阪府泉南郡熊取町大字野田 950 番地

20724-52-7196(代) 


\section{セパレール (SEPAREL)}

\section{酸素・窒素分離用中空糸膜}

DIC は，独自に開発した溶融成形法により，従来 の複雑なコーティング法と異なり，均一な遮断穈を持 つ高性能な不均質膜を一段成形法で，容易かつ安価に 製造することが可能である。

この中空糸膜は，ポリオレフィンを素材とし，特に 酸素/窒菜の分離や，気・液系でのガス交換の面で優れ た性能を持っている.

1. 用途

(1) $\mathrm{N}_{2}$ 富化…11タンク・反応槽などにおける防爆用

(2)食品・藥品類の酸化防止用

(3)生鮮食料品貯藏用 (CA 用)

(4)配管類などの設備保守用 (防錆)

(5)金属熱処理堂囲気ガス用

(6)半導体工業用 など

（2） $\mathrm{O}_{2}$ 富化…可檠品・食品産業での好気性微生物の 培責における酸素供給

(2)好気性菌による廃水処理用

(3)化学工業・医薬品工業に打的空気酸 化

（3）脱ガス…(1)逆漫透膜の供給液の脱酸素

(2)微生物培養液からの $\mathrm{CO}_{2}$ 除去

(3)超純水からの脱酸素など

2. 仕様

材 質:ポリオレフィン

膜構造：外表面に緻密層を持つ中空系型不均質膜 内径/膜厚 : $200 / 25 \mu \mathrm{m}$

酸素透過速度 : $0.2 \times 10^{-5} \mathrm{~cm}^{3}(\mathrm{STP}) / \mathrm{cm}^{2} \cdot \mathrm{sec} \cdot \mathrm{cmHg}$ $\mathrm{O}_{2} / \mathrm{N}_{2}$ 分離係数 : 3.8

水の脱酸素量 : $50 \mathrm{l} / \mathrm{h}, \mathrm{m}^{2}$ (at 40 Torr, $25^{\circ} \mathrm{C}$ )

耐 圧：約 $10 \mathrm{~kg} / \mathrm{cm}^{2}$

※関連特許 10 件出願中

3. 特徵

（1）優れたガス分離能

透過速度に優れ, かつ酸素/窒素の分離係数が $3.8 \sim 4.0$ と高い値を持つ. また, 分離能と酸素 透過量を，要望により図 1 の線上で自由に変化さ せることができる。

（2）優れたガス交換能

水への酸素供給や，水からの脱酸素・脱炭酸ガス 交換膜に優れた性能を持つ。

(3) コンパクト性

中空糸型であり, しかも細く膜厚も薄いため装置 体積当りの膜表面積を大きくすることが可能。

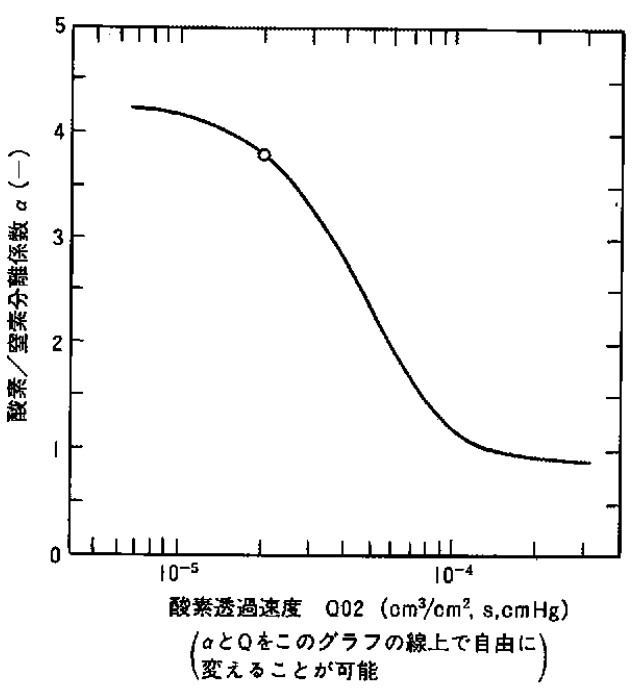

図 1 気体分離特性

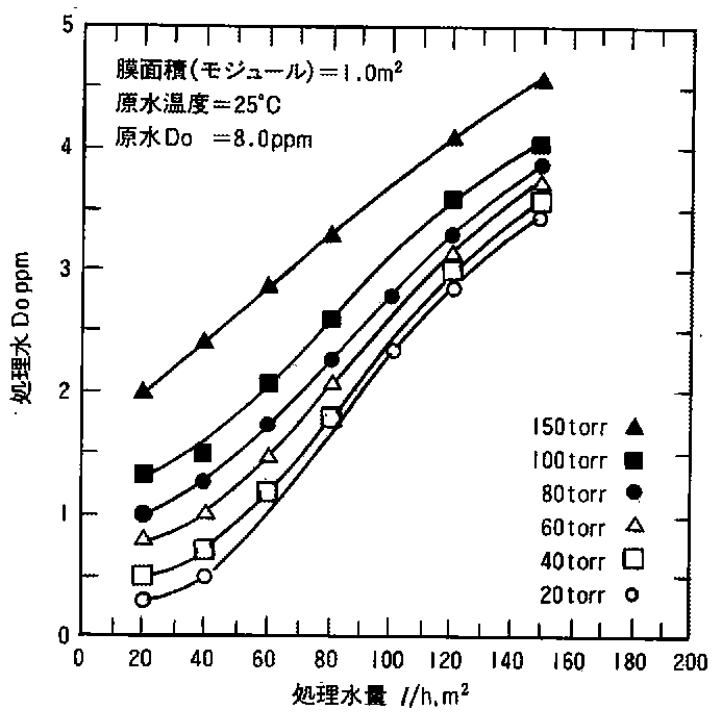

图 2 水の脱酸秦特性

（4）安全・清潔

ポリオレフィンを素材とし，溶融成形法で製造さ れるため, 溶出物が無く安全・清潔.

\section{大日本インキ化学工業（株）}

ポリマ関連企画開発室

(3103 東京都中央区日本橋 3-7-20

203-272-4511 FAX 03-274-3058 


\section{チッソ CP フィルター ${ }^{\circledR}$}

\section{ポリプロピレン, ポリエチレン, ポリエステル}

「チッソCPフィルター』とは, チッソが開発した 熱可塑性樹脂を使用した熱融着性複合瀻維（「ES 緎 維」）から製造した円筒状フィルターである.

「ES 繊維」とは，1本の細い瀻維の中に低融点成分 と高融点成分を, 低融点成分が緎維の表面となるよう に配置してなる複合緎維であり，加熱処理のみによっ て繊維形状を保持したままで，表面の低融点成分を織 維相互の交絡点で融着できる特徵を有する瀻維であ り, 昭和 55 年度の瀻維学会賞を受賞している。

CP フィルターは, この ES 紴維をかさ高なウェプ 状とし, 均一に加熱しながら低融点成分を溶融させて 繊維を点接着させながら, 中芯に巻き付けて冷却後, 抜芯切断し製品とするもので，次の特幑を有する.

(1)繊維同志がかさ高な状態で点接着しており，抵抗 が小さく沪過流量が多い.

(2)フィルターの内側から外側に向けて密度勾配をも たせてあるため，異物粒子を表面のみではなく全体 で捕集でき，沪過ライフが長い.

(3)沪過精度は, 瀻維の太さでコントロールしている が，点接着であり公称精度ではあるが優れている.

(4)瀻維を均一加熱して点接着しているため, 沪過時 に沪材など余分なものの流出がない.

(5) CP フィルターの素材はポリオレフィンであり, かつ接着などを一切使用していないため, 而薬品性 に優れている。

(6)緎維の熱融着成形体で, 肉厚も約 $20 \mathrm{~mm}$ あるた め耐圧性などの機械的強度が大きい.

(7)耐熱性は普通夕イプでは約 $80^{\circ} \mathrm{Cまでであるが,}$ 約 $120^{\circ} \mathrm{C}$ で使用可能なHタイプもある.

CP フィルターには沪過精度によって, 次の 12 種 類がある。

$\mathrm{CP}-\mathrm{A} 5 \cdots(0.5 \mu), \mathrm{CP}-\mathrm{A} 7 \cdots(0.7 \mu), \mathrm{CP}-01 \cdots(1 \mu)$ $\mathrm{CP}-03 \cdots(3 \mu), \mathrm{CP}-05 \cdots(5 \mu), \mathrm{CP}-10 \cdots(10 \mu)$ CP- $25 \cdots(25 \mu), \mathrm{CP}-50 \cdots(50 \mu), \mathrm{CP}-75 \cdots(75 \mu)$

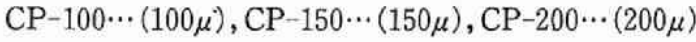

また CP フィルターの標準サイズは, 外径 $68 \mathrm{~mm}$, 内径 $30 \mathrm{~mm}$ で長さは $250 \mathrm{~mm}, 500 \mathrm{~mm}, 750 \mathrm{~mm}$ で あるが，特殊サイズについても注文に応じられる。

「チッソ CPフィルター」は, 以上のごとき特徵と 米国の食品衛生規格である F.D.A. に適合しているこ とを生かして, 次のような産業分野の清澄および選別 沪過に広く使用されている。

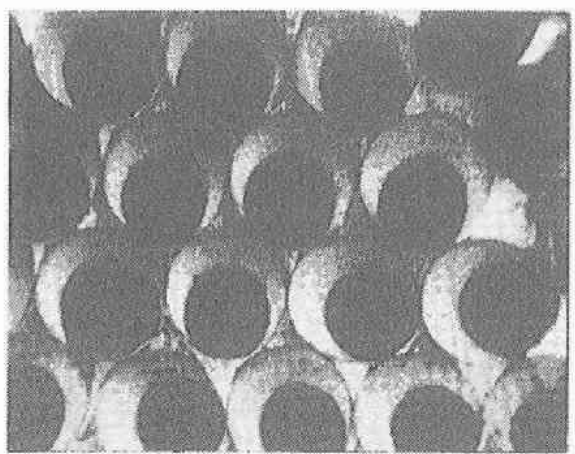

ES の緎維の断画

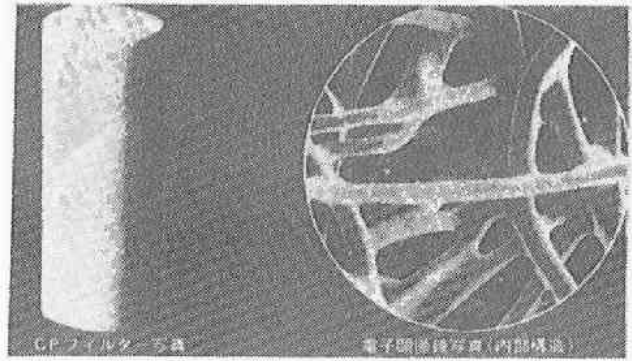

CP フィルター
a）塗料・塗装分野
b）インキ・印刷分野
c) 磁気テープ分野
d）食品・醹造分野
e）医薬品 - 医療分野
f) 水処理分野
g）その他（化学工業，メッキ，プールなど）

严530 大阪市北区中之島 3-6-32（大阪ピル）

8 06-441-3254 FAX 06-441-4458 


\section{低圧逆浸透膜 NTR-759HR}

\section{芳香族ポリアミド}

\section{1. 技術の背墇}

逆漫透膜は水溶液に漫透圧以上の圧力を加えて水中 に溶解しているイオン類や有機化合物などと水とを相 変換を伴わずに分離する機能を有する，逆浸透分離法 はその省エネルギー性, コンパクト性ゆえに, 分離・

精製・濃縮を目的として各種産業用途で広く使用され ている.

逆浸透膜性能（溶質分離性=阻止率や透過流束）は 操作圧力に依存し，圧力が低くなるほど性能低下をき たす 他方，経済性の面ではより低い圧力で高い性能 を示すほど好ましく，そのような低圧逆漫透膜が強く 望まれている。

日東電工は 1983 年に塩化ナトリウム阻止率はそれ ほど高くないが，有機化合物阻止率が高く，従来の酢 酸セルロース逆浸透膜 (CA膜) の 1/2 1/3の 10 $\mathrm{kgf} / \mathrm{cm}^{2}$ 前後の低压て運転できる逆浸透複合膜： NTR-7250を上市し，低圧逆浸透膜の時代を拓いて きた.

NTR-759HR は従来の逆漫透膜を超える, 非常に 高い溶質分離性と低圧運転可能な高い透過流束を有す る低圧逆浸透膜である。

\section{2. 構造}

NTR-759HR は厚さ $40 \mu \mathrm{m}$ のポリスルホン多孔性 支持膜の表面に溶質分離性能を支配する $0.2 \mu \mathrm{m}$ 程度 の厚さの芳香族ポリアミドから成る非常に繳密で均一 な超薄蟹（スキン層）を形成させた複合膜であり， PET 不織布で裏面が補強された構造である。

\section{3. 特幑}

NTR-759HR の溶貿分離性能を表に示す，比較の ために CA 膜の性能もあわせて表に示した. NTR$759 \mathrm{HR}$ の塩化ナトリウム阻止率は $99.5 \%$ であり， $\mathrm{CA}$ 膜のそれは $97 \%$ である。このことは膜を透過し てくる水中の塩化ナトリウム濃度が NTR-759HR で はCA 膜の $1 / 6$ であり，はるかに高純度の水が得られ ることを示している. 各種のイオンを含む通常の水道 水（電導度 $100 \sim 300 \mu \mathrm{S} / \mathrm{cm}$ ) を処理した時に, NTR $-759 \mathrm{HR}$ の透過水電遵度は $2 \sim 4 \mu \mathrm{S} / \mathrm{cm}$ である.

イソプロピルアルコールの阻止率は $96 \%$, ショ糖 の阻止率は 99.9\% 以上であり, NTR-759HR は非常 に優れた有機化合物分離性能を有している。

他方, $15 \mathrm{kgf} / \mathrm{cm}^{2}$ の圧力下での水の透過流束は $1.0 \mathrm{~m}^{3} / \mathrm{m}^{2}$ ・ day であり, CA 膜の約 3 倍の值を示す. この低压運転性ゆえに低電力消費が達成できる。
表 溶質分雕性能

\begin{tabular}{|c|c|c|c|}
\hline \multirow{2}{*}{\multicolumn{2}{|c|}{ 溶 筫 (分子量) }} & \multicolumn{2}{|c|}{ 阻 止 率 (\%) } \\
\hline & & NTR-759 HR & $\mathrm{CA}$ 眀 \\
\hline $\mathrm{NaCl}$ & (58) & 99.5 & 97 \\
\hline $\mathrm{MgCl}_{2}$ & (94) & 99.8 & 99 \\
\hline $\mathrm{MgSO}_{4}$ & (120) & 99.9 & 99 \\
\hline $\mathrm{NH}_{4} \mathrm{NO}_{3}$ & (80) & 96 & 90 \\
\hline エタノール。 & (46) & 53 & 23 \\
\hline $\begin{array}{l}\text { イソプロピル } \\
\text { アルコール }\end{array}$ & (60) & 96 & 45 \\
\hline グルコース & (180) & 99.8 & 97 \\
\hline ショ糖 & (342) & $>99.9$ & 99 \\
\hline
\end{tabular}

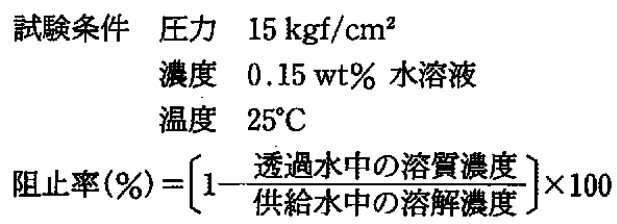

使用 $\mathrm{pH}$ 範囲は 2〜10（洗浄時は1〜11）であり， 酸およびアルカリに対する耐久性に優れている，過酸 化水素や塩素（次亜塩素酸ナトリウム）などの酸化剈 耐性にも優れており，これら酸化倣による殺菌・洗浄 が可能である.

\section{4. 用途}

NTR-759HR はこれらの特徵を生かし下記の用途 で水の精製や高純度化, 有洒物の濃縮や分離などに使 用されている。

- 地下水や水道水の脱塩用途

・超純水の造水用途

- 排水の再利用・水回収用途

・各種プロセスでの濃縮・分離用途

今後ますます多くの分野で使用されることが期待さ れる。

\section{メンブレン事業部}

\section{日東電工（株）}

支社

⑩2 東京都千代田区麯町 5-7-2（第 31 森ビル） ธ2 03-264-2101 


\section{ポーラスカーボンプレート}

\section{各種燃料電池および新型二次電池用電極板}

\section{1. 技術の背景と市場動向}

王子製紙は，長年培った抄紙技術と紙加工技術を基 盤とし，カーボンメーカーの焼成および加工技術との 組み合わせによりポーラスカーボンプレートを開発し た。このポーラスカーボンプレートは各種燃料電池お よび新型二次電池用の電極板として用いるのに十分な 機能を示す.

わが国では，燃料電池発電技術は国の大型省エネル ギー技術開発プロジェクト (ムーンライト計画) とし て位置づけられ, 昭和 50 年代に研究開発が始められ た. 燃料電池発電システムは

・高エネルギー効率

・コージェネレーション

・低公害

・分散配置に適する

特徵があるため, 現在はパイロット機によるテスト段 階であるが，数年後には実用化段階を迎えるものと考 えられている。

\section{2. 特徵および用途}

（1）材 質：カーボンなしいグラファイト

（2）代表寸法： $700 \times 700 \mathrm{~m} / \mathrm{m}(1000 \times 1000 \mathrm{~m} / \mathrm{m}$ につ いては開発の目途がついている)

（3）形 状：フラット（リブ加工も可能）

（4）特 徵：当社のポーラスカーポンは従来のポー ラスカーポンに比較して高強度であ り, 高温処理されているため, 電気伝 導性, 寸法安定性などに優れておりま す.

・曲げ強さ $250 \mathrm{kgf} / \mathrm{cm}^{2}$ 極わめて高強度です

・耐薬品性に優れています。

・耐熱性に優れています。

・電気伝導性に優れています.

（5）用途：リン酸型燃料電池用電極 メタノール型燃料電池用電極 新型二次電池用電極

\section{3. 将来の動向}

当分，用途は燃料電池関係に限られると思われる が，将来は下記分野への展開が期待される.

(1) 断熱材

（2）汇過材

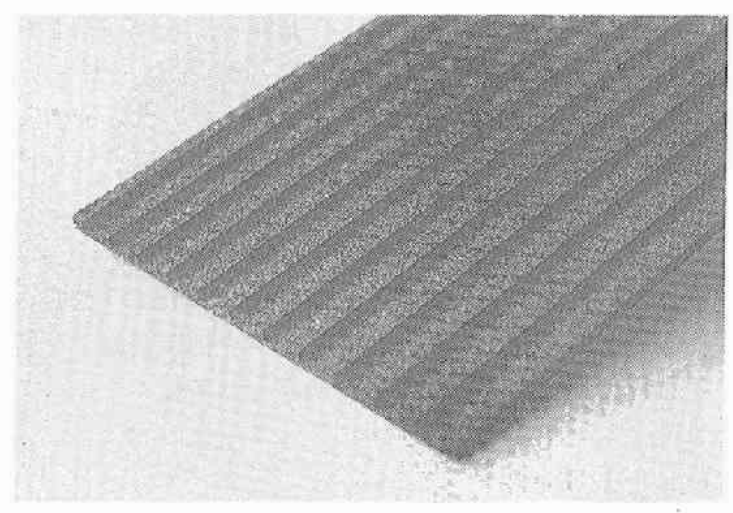

\begin{tabular}{|c|c|c|}
\hline \multicolumn{3}{|c|}{ 一般特性 } \\
\hline 特 性 & 単 位 & 当社標準品 \\
\hline 嵩 密 度 & $\mathrm{g} / \mathrm{cm}^{2}$ & 0.55 \\
\hline 気 孔 率 & $\%$ & 70 \\
\hline 固有抵抗 & $\mu \Omega \mathrm{cm}$ & 2000 \\
\hline 曲げ強さ & $\mathrm{kgf} / \mathrm{cm}^{2}$ & 250 \\
\hline 弾 性 率 & $\mathrm{kgf} / \mathrm{cm}^{2}$ & 1000 \\
\hline 熱膨張係数 & $10^{-6} /{ }^{\circ} \mathrm{C}$ & 0.8 \\
\hline 熱伝導率 & $\mathrm{kcal} / \mathrm{mhr}^{\circ} \mathrm{C}$ & 1 \\
\hline 気 孔 径 & $\mu \mathrm{m}$ & 50 \\
\hline 気体透過率 & $\mathrm{cc} / \mathrm{hrcm}^{2} \mathrm{mmAq}$ & 700 \\
\hline 灰 & $\%$ & $0.2>$ \\
\hline
\end{tabular}

商品開発部

\section{王子製紙（株）}

必 104 東京都中央区銀座 4-7-5

జా 03-563-7018 


\section{樹脂改質用シリコーン製品}

\section{シリコーン樹脂}

日常生活に不可欠な多様な樹脂類の機能特性の改買 に：シリコーン製品が使用されていることは意外に知 られていないのではないでしょうか，長い使用実續を 持つシリコーン・ポリエーテル共重合体がポりウレタ ンフォーム整泡㶡として，ジメチルシリコーン油がス チレン系樹脂の酎摩耗性向上などにその使用例をあげ ることができます，樹脂の高機能化がいっそう検討さ れる最近の傾向に対し，シリコーンを構造面および製 品形状より樹脂改質用に設計開発した各種シリコーン 新製品を今回ご紹介します:

1.「トレフィル」シリーズ

パウダー状シリコーン樹脂,「トレフィル」 F, E, R を表 1 に示します. Fシリーズはシリコーンポリマ 一を高濃度に含む流動性に優れたパウダーで, 粘稠な シリコーンのハンドリング性が著しく改善されていま す. E シリーズは $100 \%$ シリコーン分の弾性超微粒子 で,シリコーン特有の優れた柔軟性，表面特性，温度 特性を持ち，樹脂への分散性にも優れています。有機 ゴム系微粒子にない特性付与が期待されます， R シリ 一ズは融点を持たないレジン状の $100 \%$ シリコーンパ ウダーで，酎熱性，撥水性，耐候性などに特長があり ます、これらのトレフィルパウダーの考えられる用途 として, 樹脂, フィルム, 塗料, 化粧品, 研磨阂など への添加などがあげられます

\section{2. 変性シリコーン}

シリコーン反応，非反応性有機基を結合させた変性 シリコーン製品の代表例を表 2 に示します，有機基の 導入によりシリコーンを容易に有機樹脂に反底させる ことが可能となり，樹脂改質におけるシリコーンの添 加効果を十分に発揮させることができます。また相溶 性の向上による効果も期待できます。最近の例として 封止剤用エポキシ樹脂への応用が報告されています。

3. シリコーンコンセントレート BY27 シリーズ

シリコーン高分子量ポリマーを各種プラスチックス に高濃度に含有しペレタイズ化した BY27 シリーズ をご紹介します（表 3).ポリエチレン，ポリプロピ レン, ポリスチレン, ナイロン, ポリアセタールなど に添加することにより，従来シリコーン油添加に見ら れない, 改普された摺動性，成形特性を持つ樹脂を得 ることができます。
襄 1 シリコーンパウダー「トレフィル」

\begin{tabular}{cccc}
\hline 製品名 & タイプ & 粒径分布 & シリコーン分 \\
\hline $\mathrm{F}-250$ & $\mathrm{~F}$ & $<300 \mu \mathrm{m}$ & $60 \%$ \\
$\mathrm{E}-500$ & $\mathrm{E}$ & $1 \sim 5 \mu \mathrm{m}$ & $100 \%$ \\
$\mathrm{R}-902$ & $\mathrm{R}$ & $<10 \mu \mathrm{m}$ & $100 \%$ \\
\hline
\end{tabular}

舞 2 变性シリコーンの代衰製品

\begin{tabular}{lrll}
\hline 製品名 & 粘度, cs & 官能基 & 修飾位置 \\
\hline SF 8411 & 8000 & エポキシ & 側銷型 \\
SF 8417 & 1200 & アミノ & 側鋿型 \\
SH 203 & 1200 & アルキル & 側鎤型 \\
SF 8427 & 320 & アルコール & 側鎖型 \\
BY 16-853 & 30 & アミノ & 末端型 \\
\hline
\end{tabular}

表 3 シリコーンコンセントレート BY 27 シリーズ

\begin{tabular}{|c|c|c|c|}
\hline 製品名 & 外 観 & 使用樹脂 & シリコーン分 \\
\hline BY 27-001 & 白色ペレット & PP & $50 \%$ \\
\hline BY 27-004 & 同 上 & HIPS & $50 \%$ \\
\hline BY 27-005 & 同 上 & PA 66 & $50 \%$ \\
\hline BY 27-006 & 同 上 & POM & $50 \%$ \\
\hline
\end{tabular}

$$
\text { トーレ・シリコーン（株） }
$$

本店営業本部

舟 103 東京都中央区日本樆室町2-3-16 (三井ビル6号館) s 03-246-1641

大阪㗬業所

亚530 大阪市北区芝田 1-1-4（阪急ターミナルピル） 80 06-376-1251

名古屋営業部

区 450 名古屋市中村区名駅 3-25-9（堀内ビル）

2052-563-3951

研究開発本部

亚 299-01 千葉県市原市千種海岸 2-2

8 0436-21-3101 


\section{マツモトマイクロスフェアー M シリーズ}

\section{ポリメチルメタクリレート}

\section{1. 技術の背景と市場動向}

マツモトマイクロスフェアーMシリーズは, 松本油 脂製薬(株)で長年培った懸濁重合の技術を基盤とし て, 化粧品用に開発した非常に純度の高いポリメチル メタクリレートの微粒子パウダーであります. ポリメ チルメタアクリレートはコンタクトレンズ, 歯科材料 などに使用され, FDA が食品容器の材料として認め ている素材であり，周到な精製工程を通して生産した 安全性の高いパウタ゚ーです.

化粧品の肌へののりを良くし, 肌を非常に軽いタッ テで仕上げるために, 微粒子パウダーを化粧品に添加 する技術は既に実施されて扔り，今後さらに進むもの と思われます. 有機微粒子パウダーとしてナイロンな どありますが, PMMA パウダーが効果が最も高く今 後の成長が予想されます.

\section{2. 商品}

マツモトマイクロスフェアーMシリーズには, M, M-100, M-305 の三銘柄があり，M-100が主力商品 として多く使用されております。粒子径はすべて 5〜15 $\mu \mathrm{m}$ であるが, 粒子表面に差があり, マイクロ スフェアーMは粒子表面に超微粒子が付着しておる， 吸油性, 吸水性が高いものです、M-100は超微粒子 のない平滑な表面の微粒子です，M-305 は架橋型 PMMA で而溶剤性に優れた表面平滑な微粒子です.

\section{3. 特徵}

（1）粒子径が均一である. 極小微粒子を取り除いてあ りますので, 流動性, 滑り性がよく, またケーキン グの防止効果がある.

（2）球状粒子であるので，ローリング効果により化粧 品の伸びがよく、ソフトな使用感を与えます。ざら にプレス充填性が向上し, 製品の割れ，かけを防止 します.

（3）吸油性，吸水性に優れる，化粧品によく使用され る無機粉体と異なり有機物であり, 表面積の大きい ことで，油をよく吸収するため皮脂とのなじみがよ い.また，水をよく吸収するため皮脂による化粧く ずれを抑えます。

\section{4. 用途}

上記特徵を持つダウダーであり, 化粧品材料として 最適であり，本商品の用途の例として次のようなもの があります。

粉白粉

パウダーファンデーション (プレストパウダー)
ボディーパウダー (ペビーパウダー)

クリーム（クンンジングクリーム，バニシングクリ ームなど）

乳化ファンデーション

口紅

メーキャップ用品（眉墨，アイシャドーなど）

既に国内，外国ともに使用されており，まだ用途は 拡大すると予想されます。

\section{5. 今後の方向}

化粧品への微粒子パウタ゚ーの添加の方向の一つとし て，粒子内に化粧用の種々の有効成分を内包させた， マイクロカプセルの化粰品への添加が進むものと予想 されます，当社では有効成分を内包させる，マイクロ カプセル作成の技術を有しており，既に化粧品に使用 されているものがあります 内包有効成分としては, 紫外線吸収剤, 各種オイル, ビタミン, シリコンなど があり，さらに拡大されると予想されます。

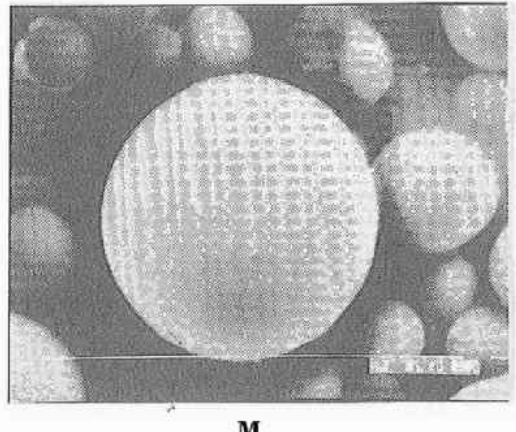

M

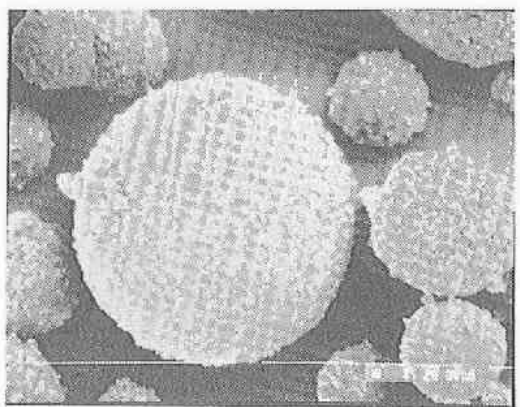

M-100

\section{松本油脂製薬（株）}

昰 581 大阪府八尾市渋川町 2-1-3

zా 0729-91-1006 FAX 0729-94-8812 


\section{マツモトマイクロスフェアー F}

\section{熱膨張性マイクロカプセル}

\section{1. 技術の背累}

松本油脂製薬(株) は，従来加ある分散技術・重合 技術・高圧ガス技術を組合せて, in situ 重合法による マイクロカプセル化技術を確立し，1979年より発泡 性マイクロカプセルを「マツモトマイクロスフェアー F」シリーズとし上市してきた. 有機発泡肪に代わる 機能性素材として種々の用途に利用されてきた。さら に新しい用途に展開されつつある。

\section{2. 特徴および用途}

マツモトマイクロスフェアーFは，低沸点有機溶脷 (膨張剤)たとえばイソブタン, ペンタン，石油エー テル，ヘキサン，低沸点八ロゲン化炭化水素などを塩 化ビニリデン，アクリロニトリル，(メタ）アクリル酸 エステルなどの熱可塑性樹脂で包み込んだ粒径が 10 30 $\mu \mathrm{m}$ のマイクロカプセルである.このマイク ロカプセルが膜ポリマーの軟化点以上に加熱される と, 膜が軟化しこのとき内包されている膨張剤の蒸気 圧により膜が押し拡げられカプセルは膨張する。 $100 \sim 150^{\circ} \mathrm{C}$ 程度で数分の加熱で直径で $4 \sim 5$ 倍, 体櫴 にして 50〜100 倍程度に脚張する。

代丧的商品としては, 塩化ビニリデン系の F-30, ニトリル系の F-50, F-80S，F-85 などがあり，F80S, F-85 は, 高温発泡タイプで, 耐溶刘性, 耐熱 性がよい.

他の膨張剤と比較して次のような特徵を持ってい る.

○低温・短時間で膨張する。

○完全な独立気泡となる:

○極薄塗膜でも膨張する。

○粒子が細かいので,分散・混練・含漫が容易である. ○低温で加工できるので, 基材の変色, 変形が少な w.

用途としては，盲人用立体コピーシステム，壁紙・ Tシャツ・トレーニングウェアーなどに, 発泡インキ としてプリントしたのち加熱して，レリーフ模様付 け，パルプとともに抄紙した威性の高い軽量紙，不織 布に含漫し発泡させた軽量芯材，合成皮革の多孔層， 不飽和ポリエステル・エポキシ樹脂注型時の収縮防止, 断熱材(層), スリップ防止材, シーリング材, クッシ ヨン材, 熱膨張性接着剂, 剶離可能な接着剂などがあ り，既に実用化されたものが多い。

このカプセルは, 湿式法（飽和蒸気）または乾式法 (熱風)によって, 密度 $0.02 \mathrm{~g} / \mathrm{cc}$ 程度のプラスチッ
表 1 マツモトマイクロスフェアー $\mathbf{F}$

\begin{tabular}{|c|c|c|c|c|}
\hline & F-30 & F-50 & $F-80 S$ & F-85 \\
\hline 平均粒径 $(\mu \mathrm{m})$ & $10 \sim 20$ & $10 \sim 20$ & $20 \sim 30$ & $20 \sim 30$ \\
\hline 発泡開始温度 $\left({ }^{\circ} \mathrm{C}\right)$ & 80 & 100 & 140 & 150 \\
\hline 比重 (乾燥物) & 1.13 & 1.02 & 1.06 & 1.04 \\
\hline \multicolumn{5}{|l|}{ 耐溶侴性") } \\
\hline メタノール & $x$ & $x$ & $x$ & $x$ \\
\hline IPA & 0 & 0 & 0 & 0 \\
\hline トルエン & 0 & 0 & 0 & 0 \\
\hline DOP & $\triangle$ & 0 & 0 & $\mathrm{O}$ \\
\hline 䤀酸エチル & $x$ & $x$ & 0 & $\mathrm{O}$ \\
\hline
\end{tabular}

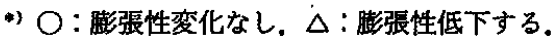
×：膨張しなくなる。

ク中空バルーンとすることができる，不飽和ポリエス テル・エポキシ樹脂やその他複合材・溎料の軽量フィ ラーとして用いられる.プラスチック中空バルーンは 弾性体であるので，これを利用した複合材はクギ打ち や鋸切りができ，ネジの保持力にも優れている，また 気泡が緻密で, 透水率が小さ?, 断熱効果も大きい. さらに焼結時, 焼失してしまうので, 焼結品の多孔質 化剂（空吵率の増加）としても利用されている.

松本油脂製薬(株) では, 未発泡·発泡いずれも湿粉 (ウェットケーキ) のみならず, ドライタイプでも販 売している.

\section{松本油脂製薬（株）}

(381 八尾市涉川町 2-1-3

× 0729-91-1006 FAX 0729-94-8812 


\section{レ 二 一}

\section{ポリアミド MXD 6 系複合材料}

\section{1. 開発の経繶}

「レニー』は三菱瓦斯化学(株) が世界に先がけて関 発したポリアミド MXD 6 系複合材料がある.

ポリアミドMXD 6 は $m$-キシリレンジアミン (MXDA) とアジピン酸とから製造される。

ポリアミドMXD 6 が工業規模で生産されるように なったのは 1970 年代初めである.

これは三菱瓦斯化学が世界で初めて独自技術によっ て純 $m$-キシンンを工業生産し, 続いて $m$-キシレン から $m$-キシンンジアミン (MXDA) の工業生産を開 始したためである。

ポリアミドMXD 6 はポリアミド 6 はポリアミド 6・6 と牥かなり性質を異にする。吸水率が低く,ガラ ス転移温度が高い. 機械的強度も強く, 特に分子鎖中 に剛直な芳香族環を有することから弾性率が高い。

しかし，球晶がポリエチレンテレフタレートと同様 に比較的大きく発達するため, 衝轓強度は必ずしも高 くない.成形材料として実用化する場合は衝撃強度の 改䍶が必須であった。

その結果，ポリアミドMXD 6 をガラス瀻維などの 高アスペクト比を有する材料で強化する方法やゴム状 高分子物とアロイ化する方法などが開発された，「 ニー」の棧生である.

\section{2. 複合強化の効果}

図に示したごとくホポリアミドMXD 6 をガラス瀻 維で強化することによって衝撃強度が著しく改善され る. 同時に, 機械的強度, 熱変形温度も向上しバラン スのとれた優れた成形材料となる。

\section{3.『レニー】の特徵と用途}

「レニー」では一般グレードのほか, 難燃, 低ソリ, 高耐衝撃, 㳊装性改良, 摺動, 発泡, 炭素瀻維強化な ど各種高機能グレードが開発されている。

『レニー』は次の特徴を有している。

（1）強度・弾性率が高い.

（2）吸水性が低く, 寸法変化, 強度低下が小さい.

（3）中温領域 $\left(80^{\circ} \mathrm{C}\right.$ 位まで) の強度保持率が高い.

（4）成形収縮率が小さい，したがって寸法精度が高 w.

（5）クリープ変形が小さい.

なかでも, 強度・弾性率は既存エンプラ中で最高の 材料に属している.アルミニウムや亜鉛などの金属の 代替材料として最適である。

自動車, 一般・精密機械, 電気・電子などの分野で

高分子 38 巻 6 月号增刊. (1989 年)
$\mathrm{H}_{2} \mathrm{NCH}_{2}>\mathrm{CH}_{2} \mathrm{NH}_{2}+\mathrm{HOOC}-\left(\mathrm{CH}_{2}\right)_{4}-\mathrm{COOH} \rightarrow$

MXDA アジピン酸

$\left.\mathrm{H}-\left[\mathrm{NHCH}_{2}\right] \mathrm{CH}_{2}-\mathrm{NHCO}-\left(\mathrm{CH}_{2}\right)_{4}-\mathrm{CO}\right]_{n}-\mathrm{OH}$

ポリアミドMXD 6

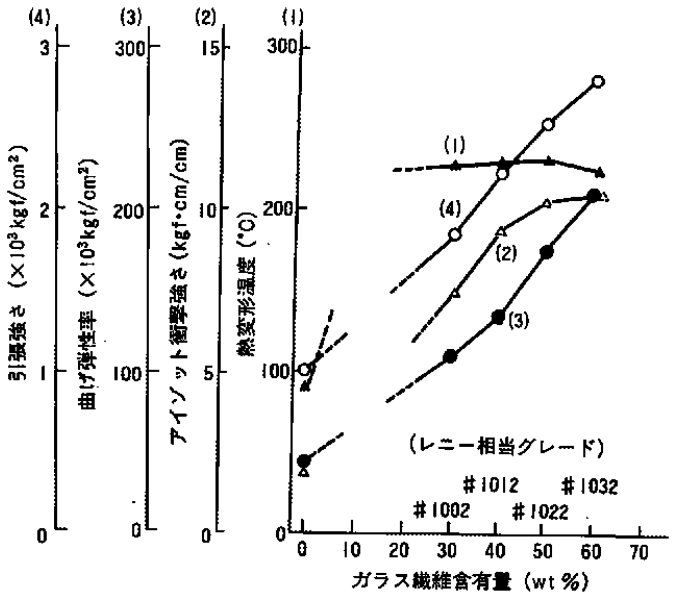

图 ポリアミドMXD6 のガラス䋐維強化による物性向上効果

機構部品として，また土木・建築用材料として用途が 広がっている。

\section{三菱瓦斯化学 (株)}

合成樹脂営業部レニー課

B 100 東京都千代田区丸の内 2-5-2（三菱ビル）

s 03-283-4882 FAX 03-287-2642 


\section{島津示差走査熱量計DSC-50/島津熱重量測定装置TGA-50}

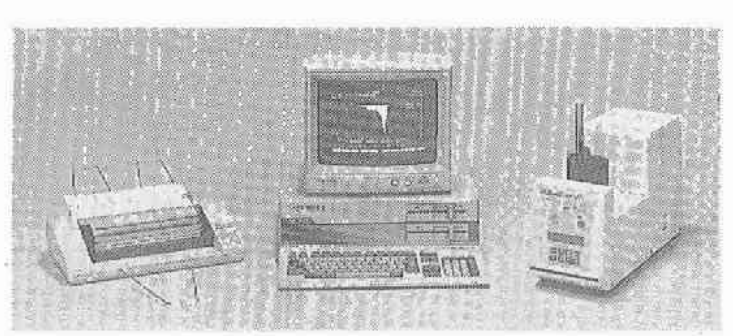

DSC-50 外観

示差走查熱量計は, 定速昇・降温や等温保持に際し ての試料の吸・発熱量や比熱容量を測定する技法です. 島津スタンドアロン DSC-50 は熱流束形示差走查熱 量計で, 試料と基準物質の出入りする単位時間あたり の熱エネルギーの差が両者の温度差に比例することか ら, 温度差を測って比熱を求めたりピーク面積から 吸・発熱量を計算します.パソコンを利用していたた きますと, 島津熱分析データ処理プログラムにより多 彩なデー夕処理結果を得ることができます.

\section{〈特長〉}

（1）DSC-50 は温度制御部，倹出部，条件設定部，伝 送インタフェース, ガス流量調節計が内蔵された 全く新しい考え方のスタンドアロンタイプです.

（2）サンプルをセットし，スタートキーを押すたけで 測定が開始され, 終了後は自動的にセルカバーが 上昇して検出部が泠却されます。

（3）伝送インターフェース（RS-232C）を内蔵して いますので, パソコンを接続し, 島津デー夕処理 パッケージをご利用いただきますと DSC データ 処理システムとなります.

(4) さらにサーマルアナライザー TA-50 と組合せ, 熱分析ネットワークシステムが構築できます.

〈高分子分野での DSC の応用〉

・ガラス転移, 融解の測定・比熱の測定

- 結晶化, 等温結晶化の測定 - 共重合体の測定

- 硬化反応の測定 - 添加剤の影響 - 結合水の測定 〈洒格〉本体 235 万円 システム 380 万円

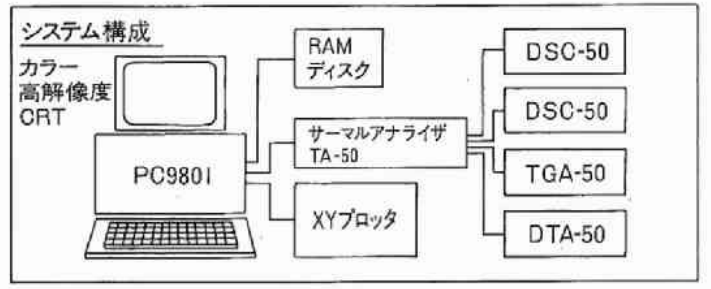

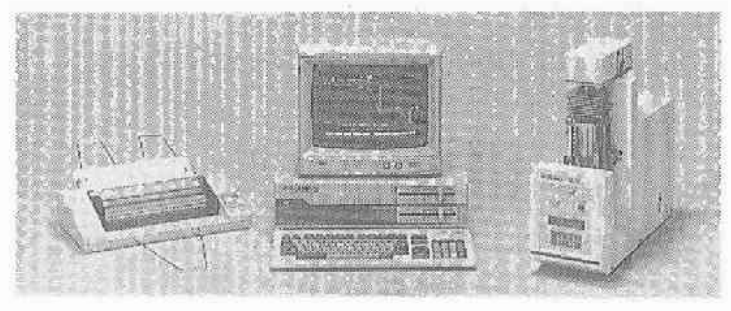

TGA-50 外観

熱重量測定は, 試料の温度を一定の速度で変化さ せ,そのときに起こる質量の変化を測定する方法で す.したがって質量変化を伴う反応, 例えば, 蒸発・ 分解・ガス吸脱着・脱水などを定量的に測定すること ができます.島津スタンドアロン TGA-50 は吊り下 げ方式の天びんですから，高感度でしかも低ノイズで す. $1 \mu \mathrm{g}$ といった微小な重量変化をも検出すること が可能です.

〈特長〉

(1) TGA-50 は温度制御部, 重量測定部, 条件設定 部, 伝送インタフェース, 微分回路, ガス流量調 節計が内蔵された全く新しい考え方のスタンドア ロンタイプです.

（2）サンプルをセットして加熱市上昇キーとスタート キーを押すだけで測定が開始されます

（3）伝送インタフェース（RS-232C）を内蔵してい ますので, パソコンを接続し, 島津データ処理パ ックージをご利用いただきますと TGA デー夕処 理システムとなります.

(4) さらにサーマルアナライザー TA-50 と組み合せ ますと, 熱分折ネットワークシステムが構築でき ます.

〈価格〉本体 235 万円

TA-50ネットワークシステムは, 4 台までのスタ ンドアロン熱分析装置を同時かつ独立に制御できま †.

\section{島津製作所}

第一科学計測事業部

画 604 京都市中京区西ノ京桑原町 1

జా 075-823-1195 


\section{Suprex 超臨界流体クロマトグラフ SFC-200A}

超臨界流体クロマトグラフィー（SFC）は，超臨界 流体を移動相として用いるクロマトグラフィーで，ガ スクロマトグラフィーと液体クロマトグラフィーの中 間に位置する新しいクロマトグラフィーです.

超臨界流体クロマトグラフィーは，不揮発性の高分 子物筫，熱に不安定な物質，UV 吸収の小さい物質， 誘導体化が困難な物質, 複雑な混合物質などの分析に 適しており, 合成高分子, 石油化学; 薬品, 食品など の分野に有用な分析手法であるといえます。

超臨界流体クロマトグラフ SFC-200A は，このよ うな SFC の利点を十分に生かす各種コンポーネント を搭載したインテグレーテッドシステムです。 〈原理〉

物質はその臨界点で液相と気相の密度が等しくな り，それ以上の温度・圧力では液体と気体の中間の物 性をもった超臨界流体として存在します，超臨界流体 の密度は圧力の上昇とともに，相変化することなく連 続的に増加します。これに伴い分子間の相互作用が増 し，溶解度が大きくなります，SFC はこの現象を利 用した分析法であり，移動相流体の密度 (圧力・温度) が分離に重要なパラメータとなります。

拡散係数が液体より大きいため，高い線速度でも高 いカラム効率が得られ，液体クロマトグラフィーより も短かい時間で分析を行うことが可能です．また，粘 度は液体よりも小さいので, キャピラリカラムを使用 することもできます。

〈構成〉

SFC-200A は, 移動相送液部, コントロール部, カラムオープン部から構成されています，移動相には 通常, 二酸化炭素 $\left(\mathrm{CO}_{2}\right)$ を用います．移動相流体は ポンプで加圧され, 次にカラムオーブンで加熱され, 超臨界流体となります，試料は固定ループ式の高圧ス イッチングバルブによりカラムに導入されます．検出 器には，水素炎イオン化検出器（FID）が榰準装備さ れています。

\section{〈特長〉}

（1）脈動のない送液ですから, 高感度検出器が使用で きます。

（2）優れたポンプ制御により,移動相は圧力, 密度, 流 量の 3 種の異ったモードでブログラムできます。

(3) カラムの温度プログラム(昇温・降温)が可能です。

(4) パックドカラムとキャピラリカラムいずれも使用 できます.

高分子 38 巻 6 月号增刊 (1989 年)

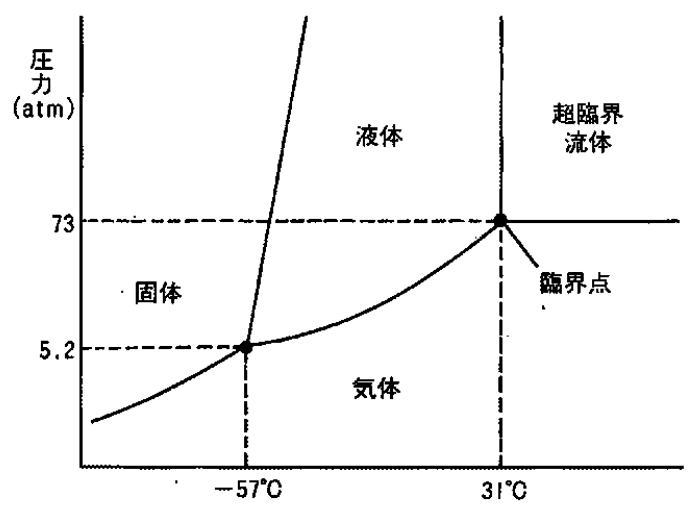

温 度

$\mathrm{CO}_{2}$ の状䈍図

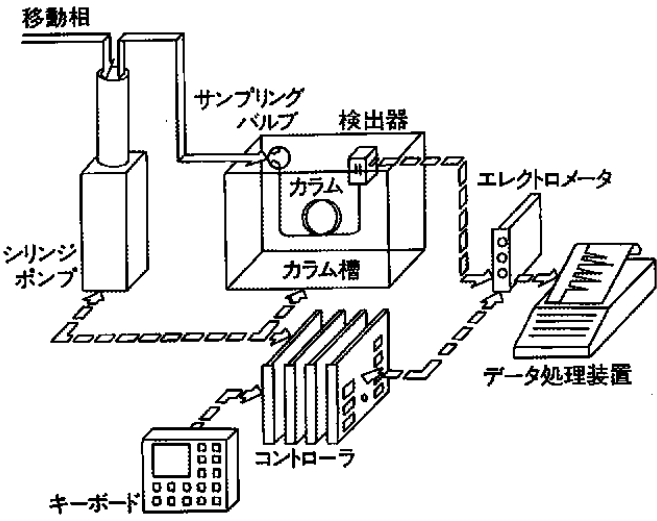

システム構成図

超䍌界流体、気体，液体の物性

\begin{tabular}{c|c|c|c}
\hline & $\begin{array}{c}\text { 拡散係数 } \\
\left(\mathrm{cm}^{2} \cdot \mathrm{S}^{-1}\right)\end{array}$ & $\begin{array}{c}\text { 粘 } \\
\left(\mathrm{g} \cdot \mathrm{cm}^{-1} \cdot \mathrm{S}^{-1}\right)\end{array}$ & $\begin{array}{c}\text { 密 度 } \\
\left(\mathrm{g} \cdot \mathrm{cm}^{-3}\right)\end{array}$ \\
\hline 気 体 & $10^{-1}$ & $10^{-4}$ & $10^{-3}$ \\
\hline $\mathrm{SFC}$ & $10^{-8} \sim 10^{-4}$ & $10^{-4} \sim 10^{-3}$ & $0.3 \sim 0.8$ \\
\hline 液 体 & $10^{-5}$ & $10^{-2}$ & 1 \\
\hline
\end{tabular}

（5）抽出ユニットを追加することで，超臨界流体抽出 (SFE) も可能となります.

〈価格〉本体 850 万円

\section{島津製作所}

第一科学計測事業部

604 京都市中京区西ノ京桑原町 1

a 075-823-1195 


\section{島津高速液体クロマトグラフ LC-6A GPC システム}

島津高速液体クロマトグラフ GPC システムは，ご 好評の高速液体クロマトグラフ LC-6A シリーズと, C-R4A の基本機能に GPC 処理プログラムを装備し て構成された最新の分析システムです,さらに目的に 応じて豊富な付属品と高性能分析カラムをお選びいた だけますので，さまざまな用途に使用できます．

\section{〈特長〉}

（1）信頼性の高い高性能高速液 体クロマトグラフ LC-6A シリーズを用いていますの で, 極めて再現性のよい安 定した分析ができます.

(2) 分析条件の変更やオートイ ンジェクタ駆動, カラムエ ージング, 運転の開始, 終了 などが全自動で行えます。

（3）リアルタイムで 2 チャンネ ル同時分析，同時記録がで きます (C-R4A 装置).

（4）目的に応じて豊富な付属品 と高性能力ラムを自由にお 選びいただけます。

\section{〈用途〉}

ポリマーの分子量放よ゙分子 量分布は，その特性の中でも最 も基本的な分子特性の一つで す. ポリマーの熱変形温度, 粘 着性, 引張強度, 而衝撃性, 溶 融流動性, 反応性, 硬化性, 耐 候性などの諸特性が，その分子 量と分子量分布に著しく影響さ れます。したがって分子量と分 子量分布の測定は, 原料抢よび 製品の品質評価, 製造工程にお ける品質解析や開発研究にきわ めて重要です. 島津 GPC シス テムは, 長年の経験と実績を生 かし, さらに独自の BASIC プ ログラムを駆使して, より正確 な GPC による物性解析を迅速 に達成できるよう配慮されてい ます. 〈価格〉 380 万円～ 510 万円
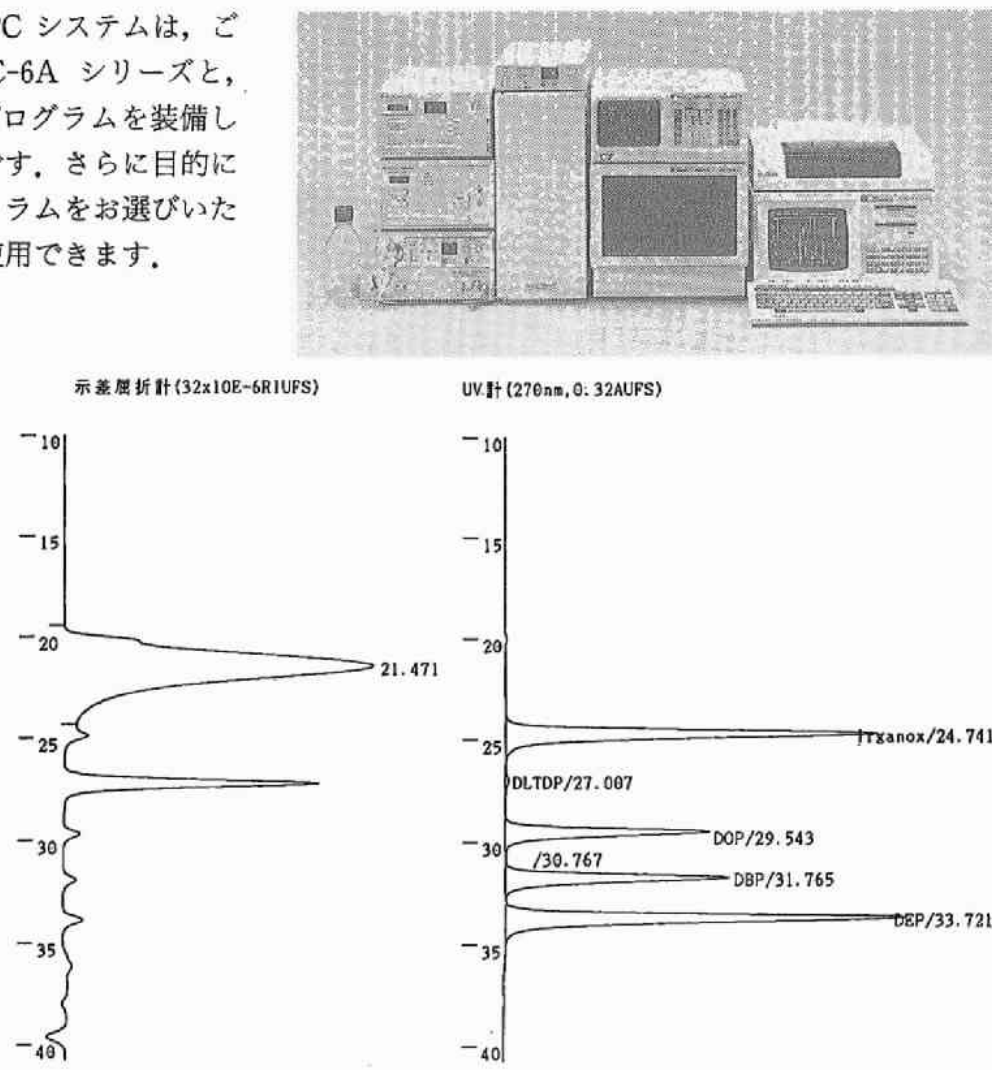

UV.It (270nm, 0: 32AUFS)

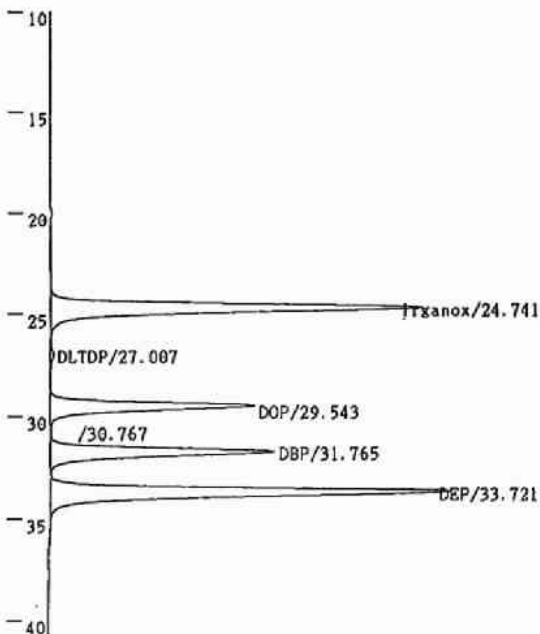

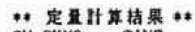

CH PKNO TIME

$\begin{array}{lll}2 & 1 & 24.741\end{array}$

$\begin{array}{ll}1 & 24.741 \\ 2 & 27.007 \\ 3 & 29.543 \\ 4 & 30.767\end{array}$

$\begin{array}{ll}4 & 30.767 \\ 5 & 31.765\end{array}$

33. 721

TOTAL
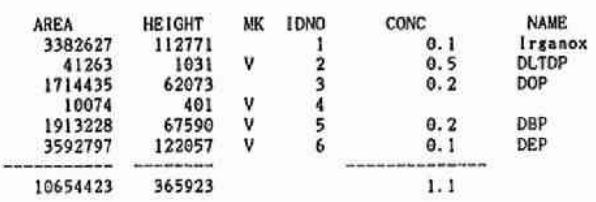

トータルチャンネル1

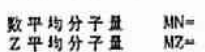

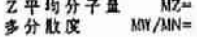

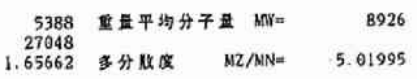

図 油脂の分析 (2 チャンネル同時記録)

四分析来件

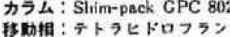

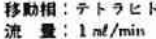

流 贯: $1 \mathrm{nt} / \mathrm{min}$

図は, 油脂 (源加剤類は任意に混合した) のUVD と RID の 2 チャンネル分析例です. RID でワックスオ リゴマの分子量測定を行い, UVD では各添加剂の濃 度計算を行ったものです.

\section{島津製作所}

第一科学計測事業部

区604 京都市中京区西ノ京桑原町 1

ชా 075-823-1195 


\section{島津フローテスタ CFT-500 形, CFT-20 形}

エンジニアリング・プラスチックで代表される高機 能性高分子材料や各種合成樹脂において, 成型圧力, 温度等の生産条件は, その機能に大きな影響を及ほし ます.

一定の温度・圧力下で流動性を示すこれらの材料の 成型・生産条件の選定, 溶融粘性・流動性の測定・研 究に島津フローテスタ CFT シリーズは貴重な情報を 与えます

用途

○成型品の温度・圧力・流出速度など加工条件の選定 ○原料の流れ特性評価による品質管理 ○熱硬化樹脂の硬化速度の測定

○粘性流動の活性化エネルギーの算出

○種々の温度・圧力化における流動曲線の記録 ○熱安定性の外観評価

\section{共通仕様}

\begin{tabular}{|c|c|c|}
\hline \multirow{2}{*}{$\begin{array}{l}\text { 形 式 } \\
\text { 加圧方式 }\end{array}$} & \multicolumn{2}{|l|}{ 定圧押出し式 } \\
\hline & \multicolumn{2}{|c|}{$\begin{array}{l}\text { 分銅による静荷重負荷方式 } \\
\text { (CFT-20では自動荷重変換) }\end{array}$} \\
\hline 試験温度 & \multicolumn{2}{|c|}{$40 \sim 400^{\circ} \mathrm{C}$ (室温 $20^{\circ} \mathrm{C} に$ ) } \\
\hline 試験方法 & \multicolumn{2}{|c|}{ a) 定温試験法 $\left(40 \sim 400^{\circ} \mathrm{C}\right)$} \\
\hline $\begin{array}{l}\text { 昇温速度 } \\
\text { 最小単位 }\end{array}$ & \multicolumn{2}{|l|}{$1.0 \sim 6.0^{\circ} \mathrm{C} / \mathrm{min}$} \\
\hline \multicolumn{3}{|l|}{ 個別仕様 } \\
\hline 種 & CFT -500 形 & CFT-20 形 \\
\hline 押出圧力 & $\begin{array}{l}0.98 \sim 49 \mathrm{MPa} \\
10 \sim 500 \mathrm{kgf} / \mathrm{cm}^{2}\end{array}$ & $\begin{array}{l}0.196 \sim 1.96 \mathrm{MPa} \\
0 \sim 500 \mathrm{kgf} / \mathrm{cm}^{2}\end{array}$ \\
\hline 試料量 & 最大 $1.5 \mathrm{~m} l$ & 最大 $5 \mathrm{ml}$ \\
\hline $\begin{array}{l}\text { ピストン } \\
\text { ストローク }\end{array}$ & 有効 $15 \mathrm{~mm}$ & 有効 $50 \mathrm{~mm}$ \\
\hline
\end{tabular}

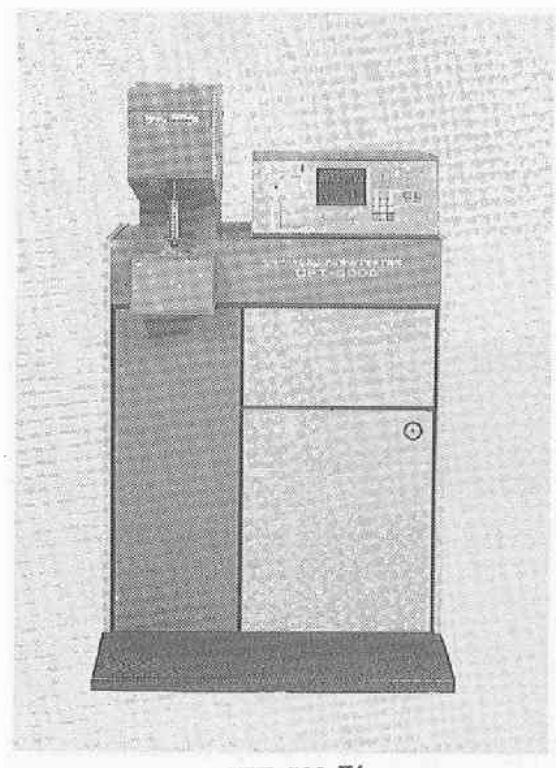

CFT-500 形

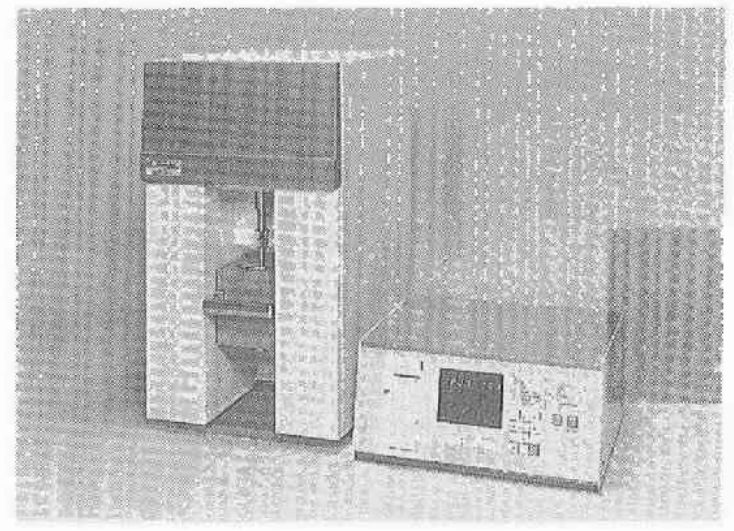

CFT-20 形

\section{島津製作所}

第二科学計測事業部

区 604 京都市中京区西ノ京桑原町 1

ช 075-431-2111 


\begin{tabular}{|c|}
\hline 島津自記分光 \\
光度訊
\end{tabular}

マルチパーパス試料測定システム/FTIR 顕微測定システム

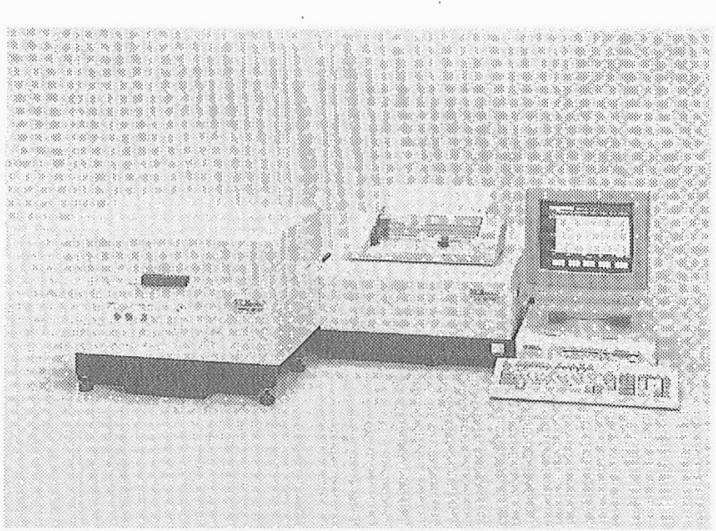

自記分光光度計 UV-3100 S 応用システム

マルチパーパス試料測定システム

多様な試料の透過・反射測定が 1 台の装置で可能で す.

島津自記分光光度計 UV-3100 S 応用システム

マルチパーパス試料測定システム

\section{〈特長〉}

（1）積分球方式で近赤外まで測定． $240 \sim 2,600 \mathrm{~nm}$ の 近赤外域まで高感度に測定できます。

（2）超ワイドの試料スペース. 直径 $305 \mathrm{~mm}$ のディス クまたは直径 $204 \times$ 長さ $300 \mathrm{~mm}$ までの試料が測 定できます。

（3）曲面試料の透過・反射測定が可能.レンズや円・ 凸面鏡も正確に測定できます。

（4）本体単独の測定波長範囲は 190〜3,200 nm まで の超ワイドです.

（5） $10 \mu$ レベルの分析ができます.

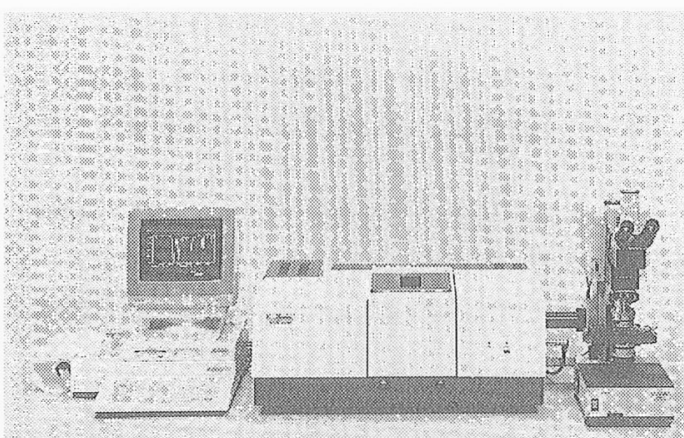

フーリエ変換赤外分光光度計 FTIR-4200 応用システム FTIR 顕微測定システム

島津フーリエ変換赤外分光光計度 FTIR-4200 応用 システム

FTIR 顕微測定システム

\section{〈特長〉}

（1）明るい光学系と高感度 MCT の採用により，暗い 試料や微小な試料の測定が容易になりました。

(2) 高感度 MCT 検出器を搭載。微小面積夕イプを搭 載していますので, 光量の無駄がなく, 最高の検 出感度が得られます。

（3）顕微透過/反射測定が可能. いずれの測定にも最 適化された光学系ですから, 最高の測定感度が得 られます。

\footnotetext{
島津製作所

第一科学計測事業部

业 604 京都市中京区西ノ京桑原町 1

2075-823-1191
} 


\section{SSC5000 熱分析システム}

\section{1. 装置概要}

熱分析装置は, 高分子材料をはじめ有機物・無機物 を問わず広い分野にわたる物質の熱物性を知る上で欠 かせないものである.よって近年では，研究開発部門 はもちろん品質管理部門などにおいても熱分析䝺置は 使用されている.

本システムは, 示差走査熱量計 (DSC)・示差熱熱重 量分析装置 (TG/DTA) ・ 熱機栈的分析装置 (TMA) のモジュール群と, これらすべてのモジュールをコン トロールし，かつ測定データを解析するステーション と呼ばれる部分からなる。このステーションは複数の 仕事を同時に並行処理できるリアルタイムマルチタス クシステムのため, 効率よく測定が行える.

\section{2. 用途}

本システムは, 生体高分子・食品・高分子材料・複 合材料・金属・セラミックスなどの, 昇降温時におけ る物理的変化をみることができる.

主な分析例

（1）融点および融解熱量

(2) ガラス転移温度の測定

（3）熱変性の測定

（4）結晶化温度・結晶転移温度の測定

（5）重合熱の定量

（6）熱分解挙動・耐熱性評価

（7）比熱の測定

（8）線膨張率・軟化温度の測定

（9）硬化挙動の測定

\section{3. 特長}

(1) リアルタイムーマルチタスク機能

3 台のモジュールの同時制御とデータ解析・データ の収納・解析結果のプロットアウトなど, 8 種類の仕 事を同時並行処理できる.よって熱分析の効率が飛踓 的にアップした。

（2）高分解能 A/D コンバー夕

測定デー夕は, 22 bit の高分解能 A/D コンバー夕 でデジタル変換される. よって測定前に感度設定の必 要が全く無く, データがスケールアウトする心配やデ ータ·を拡大しても粗くなることが無い.

(3) デー夕検索機能

ステーションには, ハート゚ディスクが内蔵されてお り，最大 800 データをメモリーすることが可能であ る.さらに，メモリーされたデータのなかから必要な データを瞬時にリストアップする検索機能を装備して

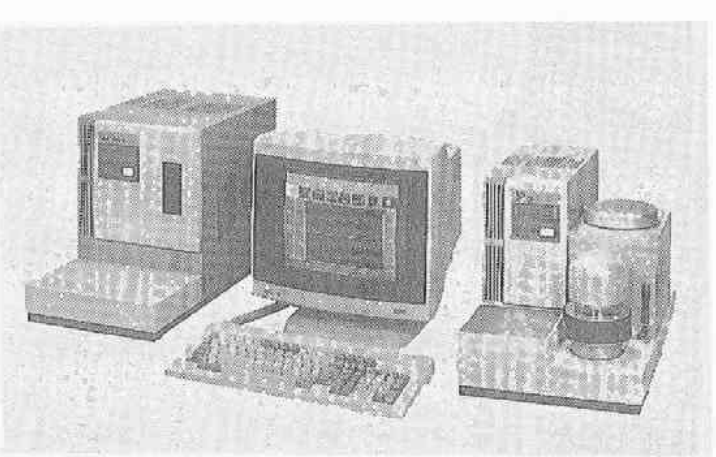

SSC 5000 熱分析システム

いる.

4. 仕様

\begin{tabular}{|c|c|c|}
\hline モジェール & 温度範囲 $\left({ }^{\circ} \mathrm{C}\right)$ & 測定感度 (/f.s.) \\
\hline DSC 100 & $-150 \sim 500$ & $\pm 20 \mu \mathrm{W} \sim \pm 40 \mathrm{~mW}$ \\
\hline DSC 210 & $-150 \sim 700$ & $\pm 100 \mu \mathrm{W} \sim \pm 100 \mathrm{~mW}$ \\
\hline DSC 300 & $\mathrm{RT} \sim 1,500$ & $\pm 10 \mathrm{~mW} \sim \pm 1,000 \mathrm{~mW}$ \\
\hline TG/DTA 200 & $\mathrm{RT} \sim 1,100$ & $\left(\begin{array}{c}\mathrm{TG} \pm 0.1 \mathrm{mg} \\
\sim \pm 200 \mathrm{mg}\end{array}\right.$ \\
\hline TG/DTA 300 & $\mathrm{RT} \sim 1,500$ & $\begin{array}{c}\text { DTA } \pm 2.5 \mu \mathrm{V} \\
\sim \pm 2,500 \mu \mathrm{V}\end{array}$ \\
\hline TMA 100 & $-150 \sim 600$ & $\pm 5 \mu \mathrm{m} \sim \pm 1 \mathrm{~mm}$ \\
\hline TMA 300 & $\mathrm{RT} \sim 1,500$ & $\pm 10 \mu \mathrm{m} \sim \pm 1 \mathrm{~mm}$ \\
\hline TMA/SS 100 & $-150 \sim 600$ & $\pm 10 \mu \mathrm{m} \sim \pm 1 \mathrm{~mm}$ \\
\hline モジュール & 測定感度 & 昭射波長 \\
\hline $\begin{array}{l}\text { 光化学反応熱 } \\
\text { 熱量計 PDC } 150\end{array}$ & $\begin{array}{l} \pm 20 \mu \mathrm{W} \sim \\
\quad \pm 80 \mathrm{~mW}\end{array}$ & $365,405,436 \mathrm{~nm}$ \\
\hline
\end{tabular}




\section{SDM 5500 動的粘弾性測定システム}

\section{1. 装置概要}

動的粘弾性測定は, 高分子物質の分子運動や分子構 造に関する情報を得ることができ，新しい材料を開発 するうえでかかすことのできない測定法である，また 工業的にも, さまざまな部品や材料の機械特性を調べ ることは, 製造工程における品質管理や, 製品性能の 評価を行ううえで重要な役割をはたしている.

本システムは, 固体試料を対象とした動的粘弾性測 定システムで, 測定方式として曲げ測定法とせん断測 定法を採用している，また本システムは，さまざまな 測定ニーズに対しても迅速に, かつ高精度で対応でき る機能と, 測定中でもデータ解析が行えるなどの高い 操作性を備えたシステムである.

\section{2. 用途}

本システムは, プラスチックやゴム, または複合材 料など,あらゆる高分子材料に適用することができ る.

\section{主な分析内容}

(1) 貯蔵弾性率 $\left(E^{\prime}, G^{\prime}\right)$

(2) 損失弾性率 $\left(E^{\prime \prime}, G^{\prime \prime}\right)$

(3) 複素弾性率の絶対值 $\left(\left|E^{*}\right|,\left|G^{*}\right|\right)$

(4) 損失正接 $(\tan \delta)$

(5) 粘性率 $(\eta)$

（6）活性化エネルギー $(\Delta E)$ の算出

（7）マスターカーブ (合成曲線) の作成

\section{3. 特長}

本システムは, 機能と操作性の観点から, 主に次の ような特長がある。

(1) 機能

・温度分散と周波数分散の同時測定ができる.

- 温度変化に伴う試料の変形による影響がなく, 弾 性率や損失正接の絶対值に対して, より信頼性の 高いデー夕が得られる.

・感度設定は一切不要で, 対数スケールまたはりニ アスケールで任意にデータの拡大縮小ができる.

(2) 操作性

・マルチタスク機能の採用により，1台のホストコ ンピュータで 3 台の装置を同時コントロールでき るうえ, 測定中でもデー夕解析や解析結果のプロ ットアウトができるなど, 複数の作業を同時平行 処理することができる.

・40メガパイトのハードディスクを搭載し，多量の データストアを可能にした。 また必要に応じてデ

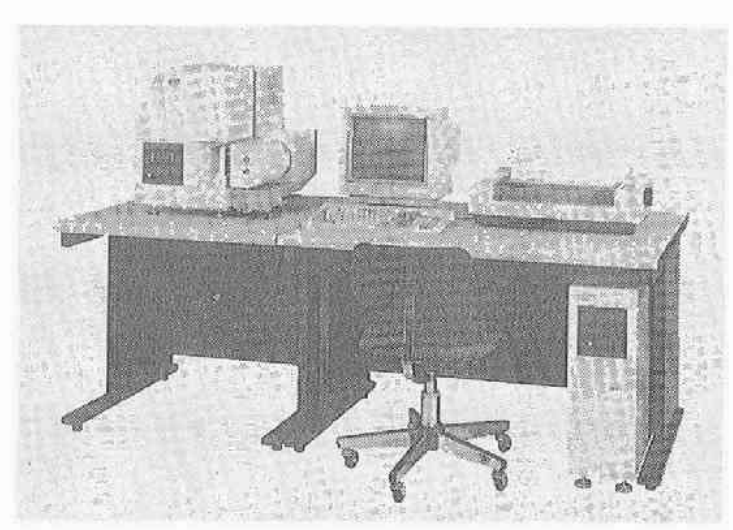

SDM 5500 動的粘弾性測定システム

一夕を 3.5 インチフロッピーディスクに転送する ことができる.

・ハードディスク内のデータを，ファイル名や測定 年月日などの条件で検索することができる.

4. 仕様

測定周波数 $\quad 0.01,0.02,0.05,0.1,0.2,0.5$, $1,2,5,10,20,50,100 \mathrm{~Hz}$

弾性率測定範囲 ヤング率 (曲げ測定) $10^{5} \sim 10^{12} \mathrm{~N} / \mathrm{m}^{2}$ 剛性率 (せん断測定) $10^{3} \sim 10^{8} \mathrm{~N} / \mathrm{m}^{2}$

最大試料寸法 曲げ測定 長さ : $50 \mathrm{~mm}$, 厚さ : 5 $\mathrm{mm}$, 幅 : $16 \mathrm{~mm}$

せん断測定 断面積 : $100 \mathrm{~mm}^{2}$, 厚 巳 : $7 \mathrm{~mm}$

温度制御モード 連続昇降温

ステップ昇降温

折線型多段組立昇降温

\section{セイコー電子工業（株）}

科学機器事業部

雷 136 東京都江東区亀戸 6-31-1

รా 03-637-1371 FAX 03-684-1279 


\section{S-RIM 対応 RIM 成形設備}

\section{S-RIM の位置}

RIM成形 (広義) $\left\{\begin{array}{l}\text { ノーマル RIM } \\ \text { R-RIM } \\ \text { S-RIM }\end{array}\right.$

・ノーマル RIM

樹脂のみによる反応射出成形

(例) ポリウレタン, ポリウレア,メトン

- R-RIM

原液中にあらかじめフィラーを混入した成形

〔例〕ポリウレタン，ポリウレア，ナイロン

- S-RIM

型内にあらかじめ強化材（マットなど）をセッ トしノーマル RIM の方法で射出，成形

(例)エポキシ, アリマックス, ポリエステル

上記の分類にようてもあきらかなように, S-RIM は他の二種の RIM (ノーマル RIM, R-RIM) では 得られない機械的強度を得ようとするところに特徵が ある.

機械的強度が高いということから，用途としてはさ まざまな強度部材が考えられており, 車の座席のフレ ームなどもその一例である, ただし, 今までのところ マット繊維の央端部が表面に多少顔を出す傾向にあっ て表面の平滑性という点で難がある. 整装しても自動 車メーカーの要求する表面輝度に達するのはむづかし 々それが S-RIM の1つの限界ともなっている.

\section{S-RIM 成形の特長}

- 原液粘度

比較的低粘度（高粘度の樹脂 だとセットされたマット内に 浸透しにくい)

・ 反応速度 厓するのに時間を要するた め比較的遅くする場合が多い

- 吐出压力…………擋拌のための圧力自体は 100 $\mathrm{kg} / \mathrm{cm}^{2}$ 以下と比較的低いが 型内への圧入のため押し込み 圧力を要す.

・型キャビティー…..可変式が望ましい, 俗に二段 圧縮と呼んでおり射出完了後 にキャビティー容積を変更す る. (縮少する)

- 射出位置 装着したマットの片寄りを防 ぐため中央部を射出口にする 例が多い.

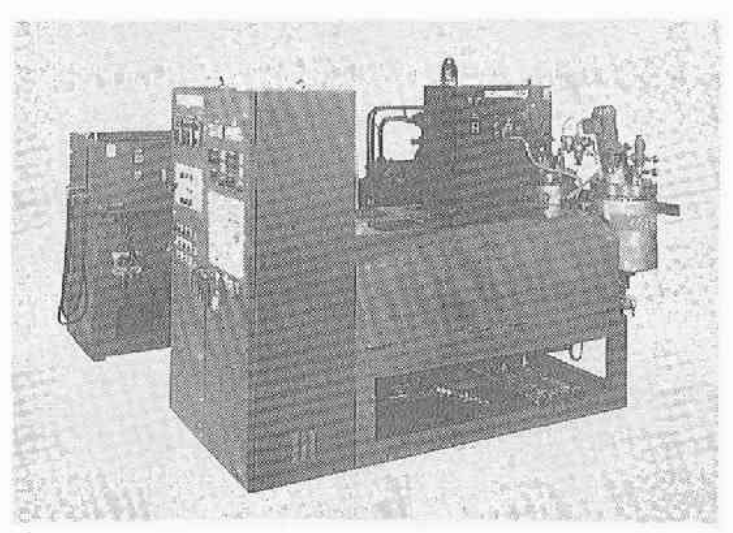

3. RIM 成形機 MC-100 シリーズの特長

○シリンダータイプであり, S-RIH はもちろんノー マル RIM， R-RIM など現在あるすべての RIM 成 形法, RIM 成形原料に対応

○サーボシステムによるフィードバック流量制御を行 い, 吐出中の吐出スピード切換可能な構造となって おり, 特に S-RIM でのさまざまな成形条件に対応 可

○擋汼性能, 而久性能のよい DB シリーズミキシンク ヘッドを装着しており，S-RIM で起こりがちなス ティッキング現象も皆無

○原液交換の手間と時間および交換に要する原液を著 しくセーブし得る機構となっており，それぞれ従来 タイプの $1 / 3 \sim 1 / 5$ の量で原液交換が可能 ○ブックタイプでアクセスのしやすい PEC 製クラン ピングユニットと組み合せることにより，容易に S RIM 成形が可能

(株) ポリウレタンエンジニアリング

E104 東京都中央区日本橋本町 4-8-17 ธా 03-270-7248 FAX 03-270-7470 


\section{全自動 $\mathbf{X}$ 線回折装置}

\section{MXP システム}

1. マックサイエンスは, 高度な材料解析時代に適合 できるX線回析装置は多面的な応用に対応でき，使い 易く安定であることだと考え MXP システムを設計い たしました。

熟成したハード技術の時代にふさわしいものとして 最新の 32 ビットワークステーションから, 機器各部 の機能は総合的に制御されシステムアップいたしまし た. したがって各部ハードは極めてシンプルなものと なり安定です.

2. 多面的な応用に対応でること，すなわち各種の 付属装置を組合せて使用することを前提として設計い たしました，また 2 台の回折計を同時そして独立に制 御操作すること, デー夕解析も並行的に処理できるこ と，のために 32 ビットワークステーションのマルチ ウインドウ, マルチマスクを活用し, 高速演算スピー ドを実現しました。

3. 多面的な応用に対応できることは同時にオペレー ターを限定せず，目的により誰にでも使えるという条 件を満たすことが時代の要請でもありましょう，初心 者から熟練者までの使用に対応できるよう自動化, 定 形化操作を充実させました，オペレーターコードを入 力することにより専用条件を設定することもできるな ど使い易いシステムとなっています，装置の状態監 視, 光学系の自動調整, 目的別最適測定条件の設定, 解析パラメータのプリセットなど測定から解析まです ベての自動化が可能なハードウェア・ソフトウェアを 準備しています。

4. あらゆる応用, 特に最新の材料開発で必要とされ る薄膜, 微少部分の解析, 高温, 低温状態での測定な どのご要求に応えられる溸新な付属装置を取り揃えて います。

小角散乱装置など各種付属装置との組合せでは, 2 台の回析計を同時並行に処理できることが極めて重要 であると考えました，そのため左右 2 台の回折計に付 属装置を装着して使用できる防X線ケース, ワークテ ーブルも用意しました， 2 台の片側の測定のための試 料交換をおこなう場合, 他方が測定中でも安全そして 確実に操作できる機能を有しています.

\section{DIP 100 シリーズ}

イメージングプレートを面検出器として組み込んだ 新しい回折装置システムです、消去, 再書き込みが可 能で半永久的に使用でき, 大幅な時間短縮と高精度化 を実現, タンパク質単単結晶の回折測定・小角散乱な

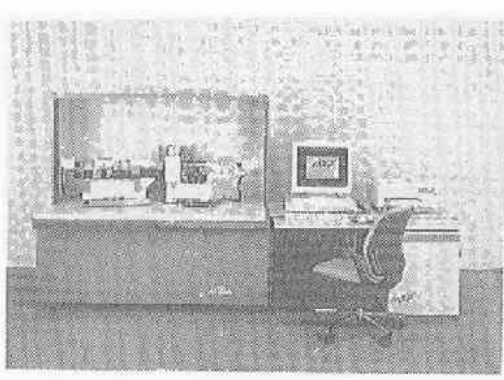

\section{全自動 X 線回折装置 MXP システム}

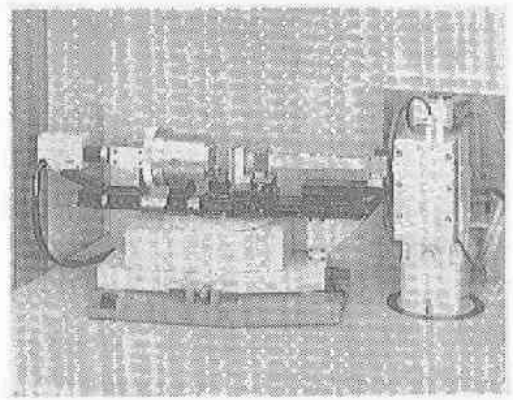

2 軸 $\mathrm{X}$ 線小角散乱装置

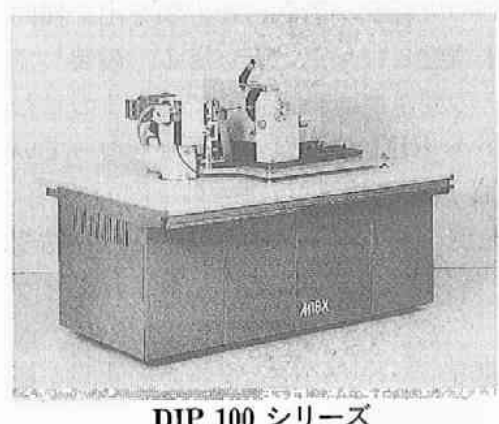

どの二次元的強度分布測定に威力を発揮します。

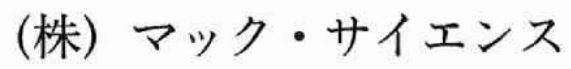

本社・東京営業所

E192 東京都八王子市中野上町 2-25-16

జ 0426-24-2201

大阪営業所

恶 532 大阪市淀川区西中島 7-7-2

新大阪ビル西館 705 号

జా 06-390-2230 


\section{熱分析装置 システム 001}

熱分析装置は，新しい時代を迎えようとしていま す、マックサイエンスの熱分析装置システム 001 は, 各種のフィールドで多目的に使用されています。この 理由は, ハードウェアの分解能, 安定性の向上とソフ トウェアの充実によって, 誰でも失敗無く, 信頼性の 高いデータが簡単に得られるからです. システムは, 熱分析処理システム TAPS 1000 を中心に測定モジュ ールが各種 (TG-DTA, DSC, TMA, D-ILATOMETER) 用意されています。冷却水は不要で, 省力化, 省スペ 一ス化，低コスト化を図っています。

\section{TAPS 1000}

4 台測定モジュールを同時制御，デー夕解析，スト ア，プロットアウトなどマルチタスク的処理可，モジ ュールは，オートレンジ，パソコンは OA 的に使用 可.

\section{TG-DTA}

差動型上皿式示差熱天科（特許申請中）は, 浮力, 対流などの影響ほとんど無し，安定した高精度測定が 高温度領域まで可.

\section{DSC}

熱フロー型のセンサーを採用し，材質は貴金属系の ため耐熱, 耐食性が良く, 高分解能. $1,500^{\circ} \mathrm{C}$ まで熱 量測定が可能. 測定温度領域によって各種を用意. 高 温域での測定では試料容器の材質によってソフト的に 熱量校正可.

\section{TMA}

天秤機構と電磁気力の発生機構を組み合わせて, 多 目的に, 低荷重, 低周波, 高感度の測定が可. 測定モ ードは, 圧縮, 引つ張り, ペネト, 周期荷重, プログ ラム荷重, 変位, プログラム変位など. 測定は, 材料 (高分子, 有機物) の伸縮, 粘弾性, 熱硬化, 軟化, $\mathrm{S} / \mathrm{S}$ ，応力緩和などが中心.

\section{DILATOMETER (TD)}

横型で水平に試料をセット．変位検出は差動方式 は, 単結晶サファイアを使用.

\section{システム 001 の機種構成}

$$
\begin{array}{ll}
\text { 制御系 } & : \text { TAPS } 1000 \\
\text { モジュール } & : \text { TG-DTA } 2010 \\
& \text { TG-DTA } 2020 \\
& \text { DSC } 3100,3200,3300 \\
& \text { TMA } 4010,4020 \\
& \text { TD } 5010,5020,5030
\end{array}
$$

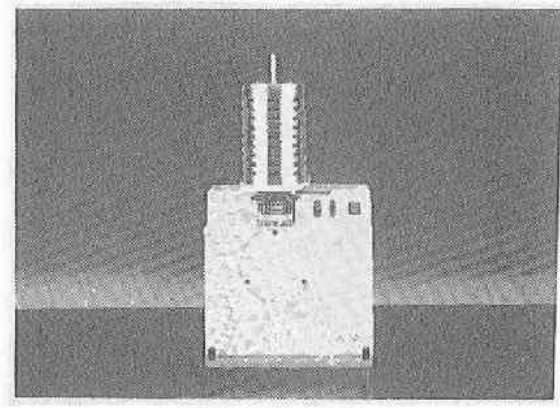

TG-DTA 2020

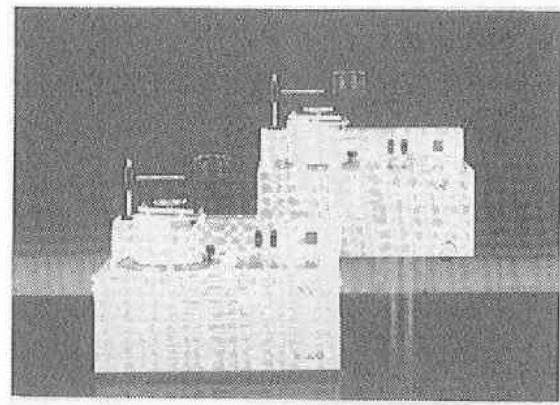

DSC $3100 \sim 3300$

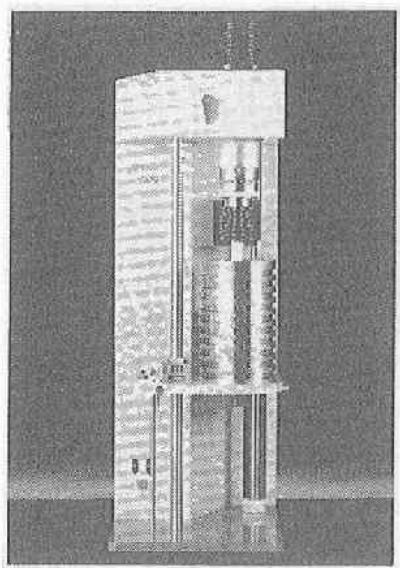

TMA

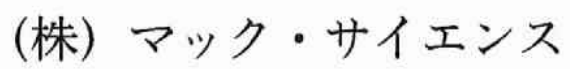

本社・東京営業所

必192 東京都八王子市中野上町 2-25-16

2ా 0426-24-2201

大阪営業所

㮩 532 大阪市淀川区西中島 7-7-2

新大阪ビル西館 705 号

జా 06-390-2230 